\title{
Nutritional modulation of DNA repair
}

Citation for published version (APA):

Langie, S. A. S. (2008). Nutritional modulation of DNA repair. [Doctoral Thesis, Maastricht University]. Maastricht University. https://doi.org/10.26481/dis.20081217sl

Document status and date:

Published: 01/01/2008

DOI:

10.26481/dis.20081217sl

Document Version:

Publisher's PDF, also known as Version of record

\section{Please check the document version of this publication:}

- A submitted manuscript is the version of the article upon submission and before peer-review. There can be important differences between the submitted version and the official published version of record.

People interested in the research are advised to contact the author for the final version of the publication, or visit the DOI to the publisher's website.

- The final author version and the galley proof are versions of the publication after peer review.

- The final published version features the final layout of the paper including the volume, issue and page numbers.

Link to publication

\footnotetext{
General rights rights.

- You may freely distribute the URL identifying the publication in the public portal. please follow below link for the End User Agreement:

www.umlib.nl/taverne-license

Take down policy

If you believe that this document breaches copyright please contact us at:

repository@maastrichtuniversity.nl

providing details and we will investigate your claim.
}

Copyright and moral rights for the publications made accessible in the public portal are retained by the authors and/or other copyright owners and it is a condition of accessing publications that users recognise and abide by the legal requirements associated with these

- Users may download and print one copy of any publication from the public portal for the purpose of private study or research.

- You may not further distribute the material or use it for any profit-making activity or commercial gain

If the publication is distributed under the terms of Article $25 \mathrm{fa}$ of the Dutch Copyright Act, indicated by the "Taverne" license above, 


\section{Nutritional Modulation of DNA Repair}

Sabine A.S. Langie 
(c) Sabine A.S. Langie, Maastricht 2008

ISBN 9789052787916

Universitaire Pers Maastricht

Cover design: Agnes Van den Bergh

Layout: $\quad$ Sabine Langie

Production: Datawyse Boekproducties, Maastricht
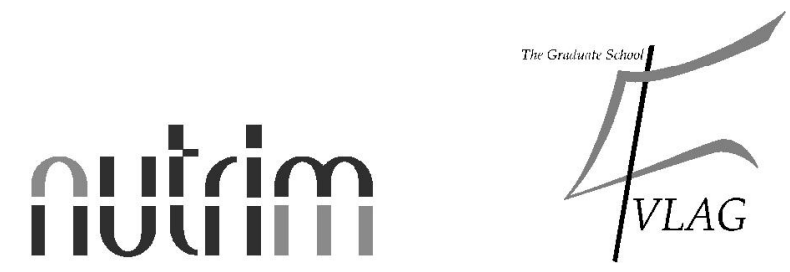

The studies presented in this thesis were performed at the Nutrition and Toxicology Research Institute Maastricht (NUTRIM), which participates in the Graduate School VLAG (Food Technology, Agrobiotechnology, Nutrition and Health Sciences), accredited by the Royal Netherlands Academy of Arts and Sciences. 


\section{Nutritional Modulation of DNA Repair}

\section{PROEFSCHRIFT}

ter verkrijging van de graad van doctor aan de Universiteit Maastricht, op gezag van de Rector Magnificus, Prof. mr. G.P.M.F. Mols volgens het besluit van het College van Decanen,

in het openbaar te verdedigen op woensdag 17 december 2008 om 12:00 uur

door

Sabine Agnes Stefanie Langie

geboren te Hasselt op 5 juni 1983

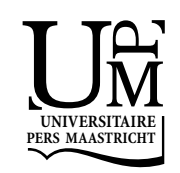




\section{Promotor:}

Prof. dr. F.J. van Schooten

\section{Copromotor:}

Dr. R.W.L. Godschalk

\section{Beoordelingscommissie:}

Prof. dr. A.Bast (voorzitter)

Prof. dr. A.R. Collins (University of Oslo, Norway)

Prof. dr. M. Kirsch-Volders (Vrije Universiteit Brussel, België)

Prof. dr. E.C.M. Mariman

Prof. dr. E.F.M. Wouters

Financial support for the publication of this thesis by the European Centre for Ecotoxicology and Toxicology of Chemicals (ECETOC, Brussels) is greatfully acknowledged. 


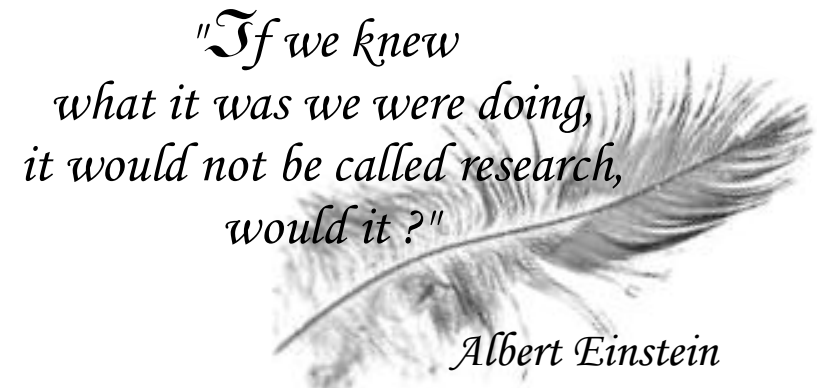





\section{Contents}

List of abbreviations $\quad 9$

$\begin{array}{lll}\text { Chapter } 1 \text { General Introduction } & 15\end{array}$

Chapter 2 Development and validation of a modified comet assay 51 to phenotypically assess nucleotide excision repair

Chapter 3 The role of glutathione in the regulation of nucleotide 69 excision repair during oxidative stress

Chapter 4 In vivo dietary modulation of nucleotide excision repair in colon tissue of newborn piglets

Chapter 5 Modulation of the nucleotide excision repair capacity in human lymphocytes by genetic and dietary factors

Chapter 6 Formation of Lysine 63-linked poly-ubiquitin chains protects human lung cells against benzo(a)pyrenediol-epoxide-induced mutagenicity

Chapter 7 Summary and General Discussion

Samenvatting en Algemene Discussie

Appendix Woord van Dank

Curriculum Vitae 



\section{List of abbreviations}





\begin{tabular}{|c|c|}
\hline 8-OHdG & 8-hydroxydeoxyguanosine \\
\hline 8-oxodG & 7-hydro-8-oxo-2'-deoxyguanosine \\
\hline A549-cells & Human epithelial lung carcinoma cells \\
\hline AICR & American Institute for Cancer Research \\
\hline AM & Ante Meridiam \\
\hline AP-1 & Activator Protein-1 \\
\hline ATP & Adenosine TriPhosphate \\
\hline $\mathrm{B}[\mathrm{a}] \mathrm{P}$ & Benzo[a]pyrene \\
\hline BER & Base Excision Repair \\
\hline $\mathrm{bp}$ & base pairs \\
\hline BPDE & Benzo[a]pyrene-diol-epoxide \\
\hline BSA & Bovine Serum Albumin \\
\hline BSO & D,L-buthione-S,R-sulfoximine \\
\hline
\end{tabular}

$\begin{array}{ll}\text { cDNA } & \text { copy Deoxyribose Nucleic Acid } \\ \text { CS } & \text { Cockayne Syndrome } \\ \text { Ct } & \text { threshold Cycle } \\ \text { CYP450 } & \text { Cytochroom-P450 }\end{array}$

$\begin{array}{ll}\text { DDT } & \text { DNA Damage Tolerance } \\ \text { dG } & \text { 2'-deoxyguanosine } \\ \text { DMEM } & \text { Dulbecco's Modified Eagle's Medium } \\ \text { DMSO } & \text { Dimethylsulfoxide } \\ \text { DNA } & \text { Deoxyribose Nucleic Acid } \\ \text { dNTP } & \text { deoxyNucleotideTriPhosphate } \\ \text { DRC } & \text { DNA Repair Capacity } \\ \text { DTT } & \text { Dithiothreitol }\end{array}$

$\begin{array}{ll}\text { ECD } & \begin{array}{l}\text { Electro Chemical Detection } \\ \text { Ethylene Diamine Tetraacetic Acid } \\ \text { EDTA }\end{array} \\ \text { e.g. } & \begin{array}{l}\text { Excision Repair Cross-Complementing } \\ \text { ERCC }\end{array} \\ \text { ESCODD } & \text { European Standards Committee on Oxidative DNA Damage } \\ \text { FACS } & \text { Fluorescent Activated Cell Sorting } \\ \text { FCS } & \text { Fetal Calf Serum } \\ \text { GCMS } & \text { Gas Chromatography Mass-Spectometry } \\ \text { GFP } & \text { Green Fluorescent Protein } \\ \text { GGR } & \text { Global Genome Repair } \\ \text { GSH } & \text { Glutathione }\end{array}$




$\begin{array}{ll}\text { GST } & \text { Glutathione S-transferase } \\ \text { HBSS } & \text { Hanks Balanced Salt Solution } \\ \text { HeLa-cells } & \text { cell line derived from cervical cancer cells from Henrietta Lacks } \\ \text { HEPES } & \text { 4-(2-hydroxyethyl)-1-piperazineethanesulfonic acid } \\ \mathrm{H}_{2} \mathrm{O}_{2} & \text { Hydrogen peroxide } \\ \text { HPLC } & \text { High Performance Liquid Chromatography } \\ \text { HPLC-ECD } & \text { HPLC with ElectroChemical Detection } \\ \text { HPRT } & \text { Hypoxantine-guanine PhosphoRibosyl Transferase } \\ \text { IARC } & \text { International Agency for Research on Cancer } \\ \text { i.e. } & \text { id est (that is) } \\ \text { K63R } & \text { mutation at location 63 from Lysine (K) to Arginine (R) } \\ \text { LPM } & \text { Low Melting Point agarose } \\ \text { LC } 50 & \text { Lethal Concentration to 50\% of the cells/animals exposed to it } \\ \text { MEM } & \text { Minimum Essential Medium } \\ \text { mRNA } & \text { messenger RiboNucleic Acid } \\ \text { MTT } & \text { 3-(4, 5-dimethylthiazol-2-yl)-2,5-diphenyl-tetrazolium } \\ \text { NER } & \text { Nucleotide Excision Repair } \\ \text { OGG1 } & \text { 8-oxoguanine DNA glycosylase 1 } \\ \text { PAH } & \text { Polycyclic Aromatic Hydrocarbons } \\ \text { PBS } & \text { Phosphate Buffered Saline } \\ \text { PCNA } & \text { Proliferating Cell Nuclear Antigen } \\ \text { PCR } & \text { Polymerase Chain Reaction } \\ \text { POL } & \text { Polymerase } \\ \text { puro } & \text { puromycin } \\ \text { RNA } & \text { RiboNucleic Acid } \\ \text { ROS } & \text { Reactive Oxygen Species } \\ \text { rpm } & \text { rounds per minute } \\ \text { rs\# } & \text { RefSNp accession ID } \\ \text { RT-PCR } & \text { Reverse Transcription Polymerase Chain Reaction } \\ \text { SBE } & \text { Single Base Extension } \\ \text { SD } & \text { Standard Error } \\ \text { SDS } & \text { SE }\end{array}$


SNP Single Nucleotide Polymorphism

TEAC Trolox Equivalent Antioxidant Capacity

TCR Transcription Coupled Repair

$\mathrm{TI}$

Tail Intensity

Tm melting Temperature

TM Tail Moment

TLC Thin Layer Chromatography

TLS TransLesion Synthesis

Ub Ubiquitin

UV Ultra Violet light

WCRF World Cancer Research Fund

WBC White Blood Cells

WT Wild Type

XP Xeroderma Pigmentosum

XRCC X-ray Repair Cross-Complementing 



\section{Chapter 1}

\section{General Introduction}

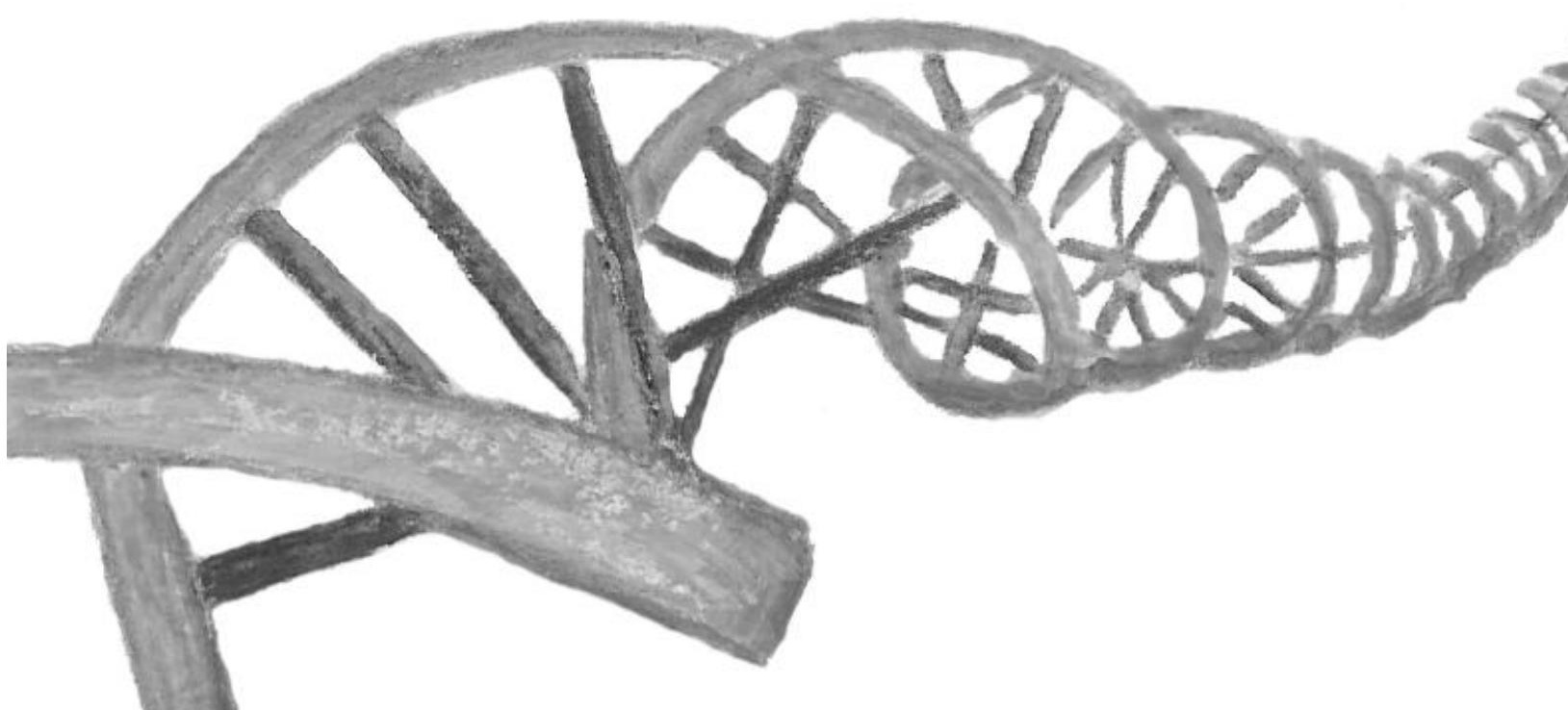




\section{Chapter 1}

Cancer is an ancient disease, which has afflicted animals since long before man appeared on earth [1,2]. Written records concerning cancer can be traced back to ancient Egypt [3]. Furthermore, the ancient Greek physician Hippocrates, who lived ca. $460 \mathrm{BC}-370 \mathrm{BC}$, was the first to describe cancer as 'karkinos'. At that time the involvement of environmental factors in the onset of disease was not known. The causal relationship between exposure to environmental agents and cancer development was only recognized in 1775 [4]. The English surgeon Percivall Pott described a link between the incidence of cancerous alterations in the skin of the scrotum of London chimney sweeps and their repeated exposure to soot. Still in the $18^{\text {th }}$ century, John Hill observed an association between long-term exposure to snuff and the occurrence of nasal mucosa cancer. By the end of the nineteenth century it had become evident that occupational exposure to certain chemicals or mixtures of chemicals had carcinogenic effects [5].

In the era before the discovery of the DNA structure by Watson and Crick, the development of cancer was believed to be due to interactions between chemical carcinogens and proteins in specific tissues [6]. It was only by the end of the 1960s that studies revealed the correlation between the DNA binding capacity of carcinogens and their biological potency [5]. At that time it became clear that environmental carcinogens to which humans are exposed exert their biological effects by binding to the DNA. Fortunately, humans possess various DNA repair pathways to prevent the persistence of such DNA lesions, maintaining genome stability. However, if DNA damages are not eliminated by DNA repair systems before cellular division, the lesions can become permanent. Due to the persistence of the DNA lesion, incorporation of the wrong nucleotide opposite the damaged site may occur during DNA replication, resulting in irreversible changes/mutations in the nucleotide sequence that can subsequently lead to the onset of cancer. Figure 1 shows the distinct stages of the carcinogenic process; initiation, promotion and progression.

Since, DNA damages have been established as the event which "kick-starts" the multi-step carcinogenic process [7], DNA repair systems play a crucial role in the prevention of chemical carcinogenesis by removing the damages in time. However, interactions between environmental, nutritional and genetic factors can deteriorate or improve the efficiency of DNA repair processes. The significance of genetic factors is for instance illustrated by the occurrence of rare autosomal recessive disorders like xeroderma pigmentosum (XP) and Cockayne syndrome (CS) [8] that involve defective DNA repair due to alterations in the genome, leading to increased cancer rates. As such, the capacity to repair DNA damage and the subsequent risk of developing cancer can vary between individuals and may change throughout the life course as a consequence of interactions between genetic inheritances, dietary and environmental exposures, and chance events. 


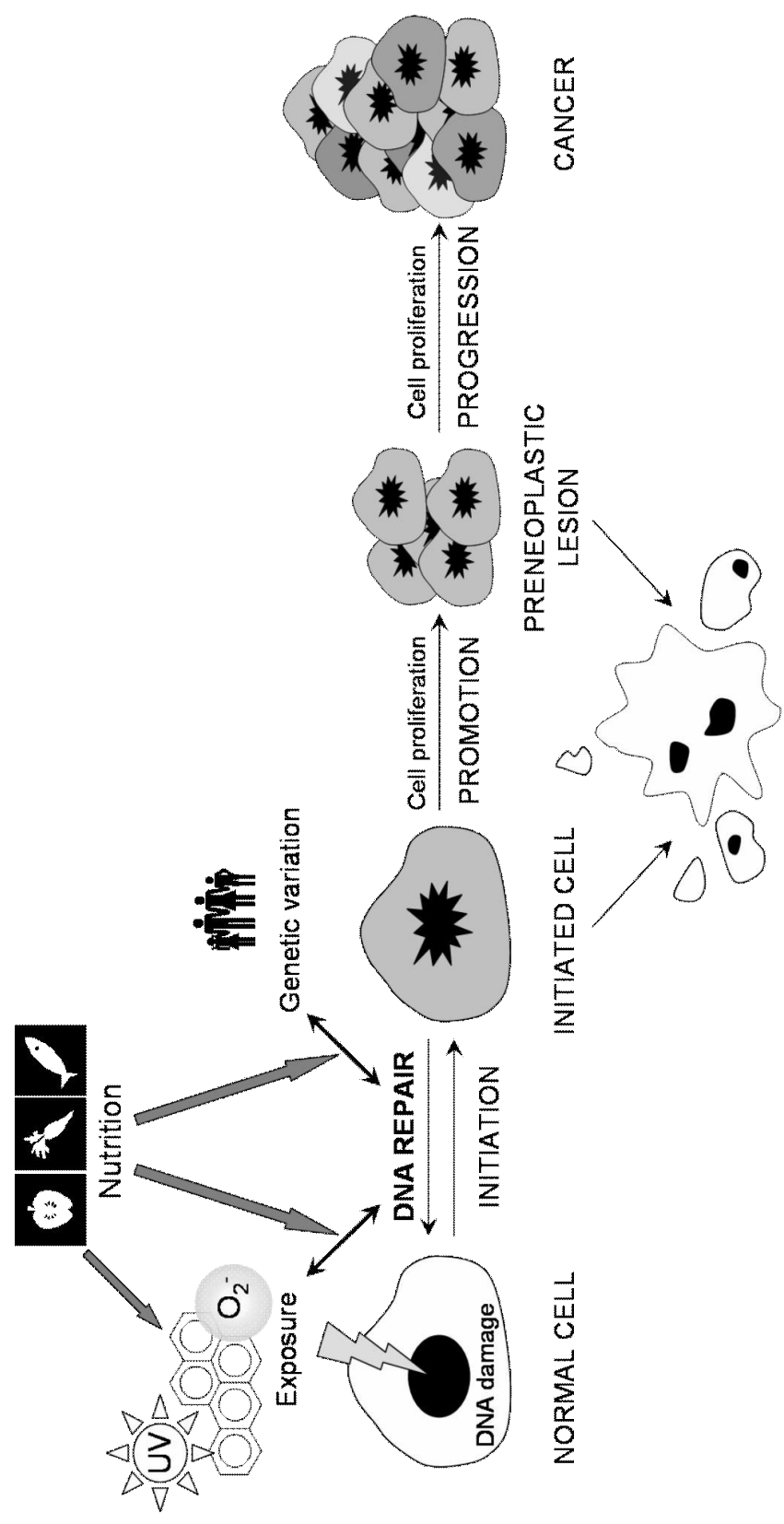

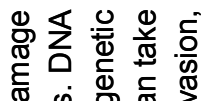

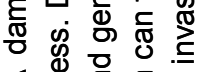

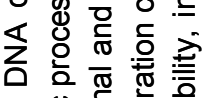
i 을 으 는 혼 등 험 은 흔

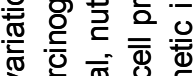

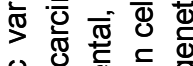
일 동 ‘ 응 은 을 ¿ তে 드 잃

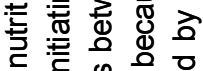
政 䓂旁 은 웅 我鄗 定

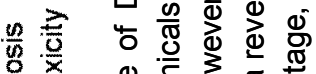

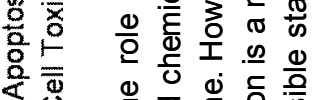
Ð 仓

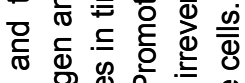

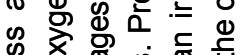

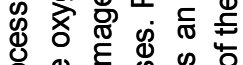
인 $\frac{1}{0}$ \& 응

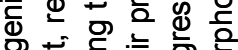

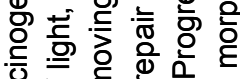

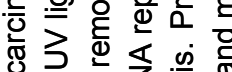

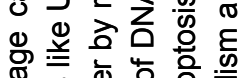
苋 心 至

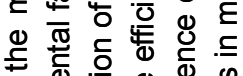
ডั 交은 ¿ฏ

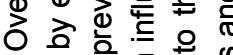
- ఫ্ঠ

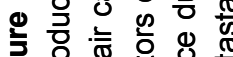

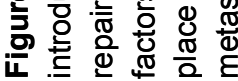




\section{Chapter 1}

\section{Biomarkers of chemical carcinogenesis}

During daily live all living organisms are constantly exposed to a wide variety of environmental chemicals including polycyclic aromatic hydrocarbons (PAHs) that can introduce DNA lesions, leading to genomic instability. Some lesions like double strand breaks can lead to chromosome aberrations, while structural damage to DNA bases often interfere with DNA replication. If these DNA damages remain unrepaired, they become self-perpetuating mutations that can alter the genetic information and integrity of the DNA, contributing to ageing and human degenerative diseases such as cancer [9-12].

The molecular epidemiological approach by measuring molecular biomarkers has been used in medicine and toxicology for many years to assist in monitoring of environmental exposures, identifying of disease-causing or protective agents, and defining of individual susceptibility or health risks. "Biomarkers" were initially defined by an NIH Study Group as a characteristic that is objectively measured and evaluated as an indicator of normal physiologic or pathologic processes, or pharmacologic responses to a therapeutic intervention [13]. Nowadays, the term usually refers to "molecular or cellular biomarkers" as indicators of biological events that may elucidate relationships between environmental hazards, human health effects and disease. Biomarkers are typically measured in biological samples like blood and urine that can be collected from patients or healthy volunteers during observational or intervention studies in a noninvasive manner. Of course it would be more informative to look directly at the target organ, though, due to practical and ethical considerations the availability of tissues for analysis is limited.

Exposure to carcinogens can be assessed by measuring DNA damage, DNA or protein adducts, and metabolites excreted in the urine. These markers are classified as biomarkers of exposure. If these DNA adducts are not adequately repaired before DNA replication takes place, they will become mutations. Mutations as well as other DNA alterations (e.g. chromosome aberrations, micronuclei) introduced by chemical carcinogens represent biomarkers of effect. Inter-individual differences in response to these environmental agents can be due to genetic and phenotypic variations in for instance the metabolization of carcinogens and repair of the induced DNA damages. These differences can be monitored as biomarkers of individual susceptibility. A broad range of biomarkers can thus be used in the molecular epidemiology (see Figure 2), which will be explained in more detail in the following paragraphs, using the $\mathrm{PAH}$ benzo[a]pyrene as an example. 


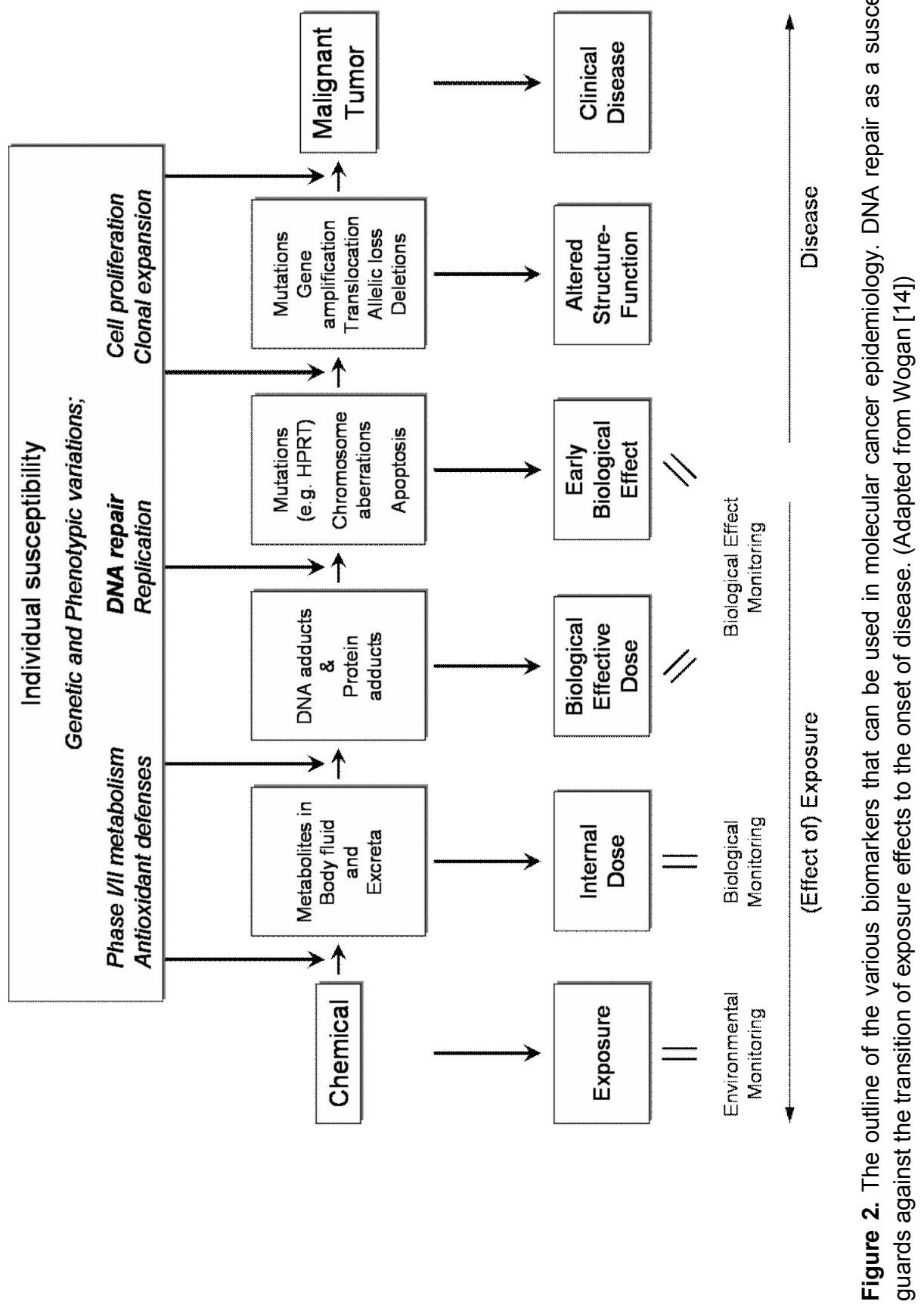




\section{Chapter 1}

\section{Monitoring of environmental exposure to PAHs}

Polycyclic aromatic hydrocarbons (PAHs) represent a large group of structurally related compounds that are produced during incomplete combustion of organic materials such as wood, fossil fuels or tobacco [15]. In addition, PAHs may be present in food as contaminants originating from for instance environmental pollution or they can be formed during grilling of food. These hydrocarbons belong to a class of ubiquitous environmental pollutants. Importantly, they are found to be carcinogenic in a variety of laboratory animals and are suspected to be carcinogenic in humans [16]. Benzo[a]pyrene $(\mathrm{B}[\mathrm{a}] \mathrm{P})$ is the best studied $\mathrm{PAH}$, especially with regard to metabolism and toxicological potential, and is therefore generally considered as a model carcinogen.

PAHs, including $\mathrm{B}[\mathrm{a}] \mathrm{P}$, are lipophilic compounds which will accumulate in organisms, unless they are metabolised and detoxified to water-soluble derivates that can be excreted [15]. Paradoxically, $\mathrm{B}[\mathrm{a}] \mathrm{P}$ itself is not carcinogenic and obtains its carcinogenic potential only after metabolic activation via a multi-step metabolic process, catalysed by specific enzymes.

The first, most common known pathway (Figure 3, vertical) starts with an epoxidation reaction involving the addition of an oxygen atom across a double bound. This initial step is catalysed by the mixed-function oxidase (MFO) system, which requires $\mathrm{NADH}$ or $\mathrm{NADPH}$ and molecular oxygen to convert $\mathrm{B}[\mathrm{a}] \mathrm{P}$ to polar hydroxyl derivates and arene oxides [17]. Epoxidation of $\mathrm{B}[\mathrm{a}] \mathrm{P}$ by MFO cytochromeP450 enzymes (CYP450s) leads to the formation of $( \pm$ )-B[a]P-7,8-epoxides, which are in turn substrates for epoxide hydrolases to form stereoisomeric dihydrodiols. These are further oxidized to the ( \pm )-anti- and ( \pm )-syn-B[a]P-7,8-dihydrodiol-9,10epoxides (BPDE) by the action of CYP450s, with $( \pm)$-anti-BPDE being the predominant metabolite [17]. This isomer has the greatest biological activity of the four enantiomers. In addition ( \pm )-anti-BPDE forms the most covalent bindings with the DNA and as such it has the highest tumor-inducing activity [18]. Therefore, studies as described in the present thesis specifically focused on ( \pm )-anti-BPDE as a model PAH.

In the second pathway (Figure 3, horizontal), the trans-B[a]P-7,8-dihydrodiols are further oxidized by dihydrodiol dehydrogenase members of the aldo-keto reductase $(A K R)$ superfamily to produce reactive and redox-active o-quinones. The AKRs catalyze the $\mathrm{NADP}^{+}$-dependent oxidation of trans-B[a]P-7,8-dihydrodiol to form a ketol that spontaneously rearranges to a catechol [19]. The catechol undergoes two sequential one-electron oxidations to yield an o-semiquinone radical anion and subsequently the corresponding redox-active and electrophilic oquinones. The catechol metabolite can be regenerated by NADPH-dependent two electron reduction of the quinone metabolite resulting in redox cycling [19,21].

A third possible pathway involves the formation of B[a]P-radical cations, catalyzed by various enzyme systems like CYP450s, prostaglandine-H-synthetase and peroxidases [22]. 


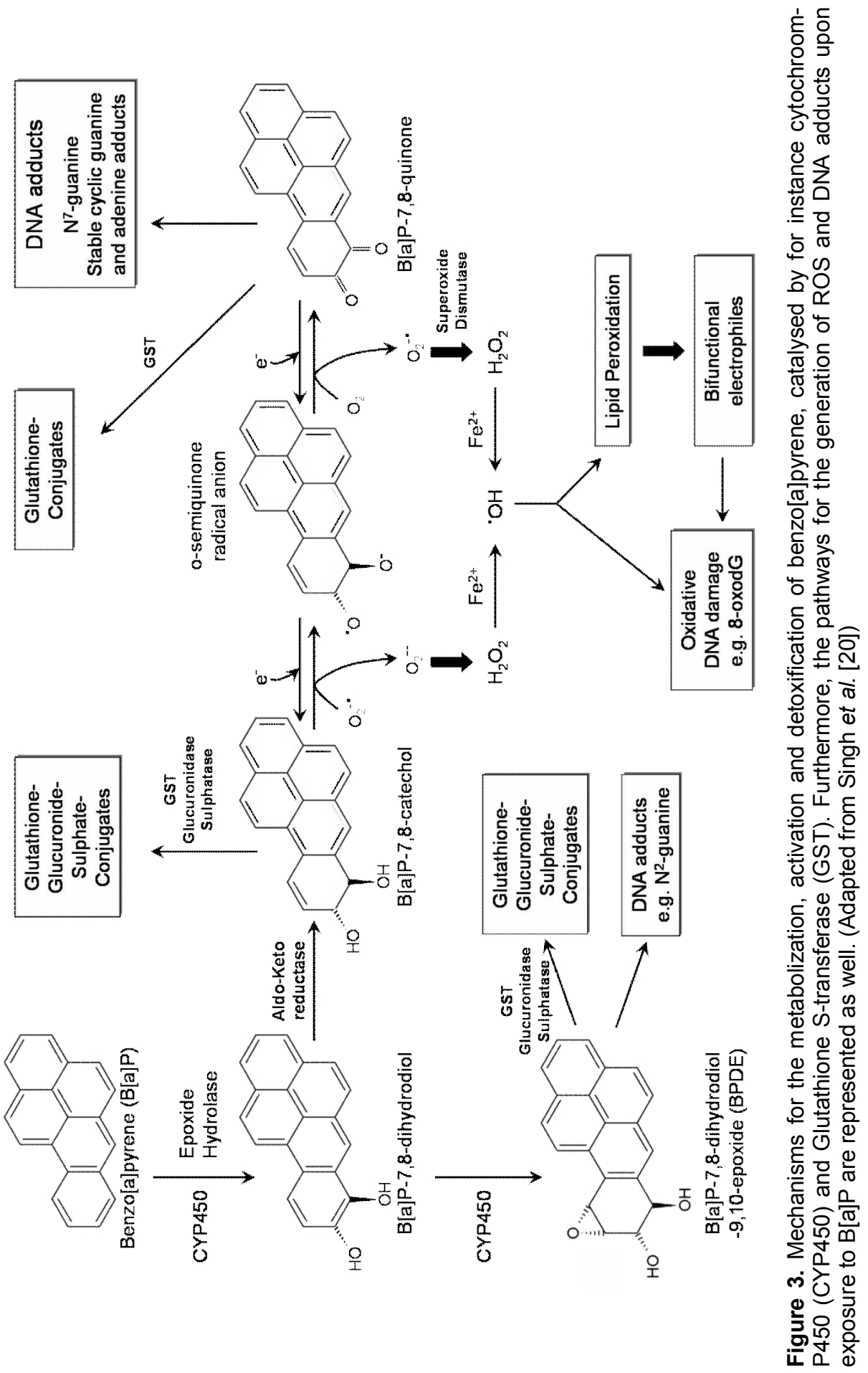




\section{Chapter 1}

As a further detoxification step, the $\mathrm{B}[\mathrm{a}] \mathrm{P}$-epoxides as well as quinones and hydroperoxides can be conjugated with glutathione. This conjugation is regarded as a crucial detoxification reaction and is mediated by glutathione S-transferases (GSTs) such as the isoform GSTM1. The epoxides that are not conjugated with glutathione are converted into phenols and diols. These hydrolyzed metabolites are often not sufficiently polar to be excreted and are therefore further conjugated with glucuronic or sulfuric acids to facilitate their excretion [15]. As a result, predominantly water-soluble derivatives are formed and excreted. Monitoring concentrations of $\mathrm{B}[\mathrm{a}] \mathrm{P}$ or its metabolites in body fluids and excreta, as biomarkers of exposure, can provide information on the internal dose after $\mathrm{B}[\mathrm{a}] \mathrm{P}$ exposure. Moreover, genetic variations in genes involved in metabolism and detoxification such as CYP1A1, GSTM1 and GSTT1 could potentially affect an individual susceptibility to the adverse effects of environmental carcinogens like B[a]P. For instance, many studies have found that loss of GSTM1 was associated with higher levels of biomarkers of exposure and effect such as DNA adducts, metabolites, and genotoxic damage [23-26].

Although, measuring $\mathrm{B}[\mathrm{a}] \mathrm{P}$ metabolites in body fluids and excreta can be an informative biomarker of exposure, such measurements do not necessarily represent the biological effective dose. The concentration of $\mathrm{B}[\mathrm{a}] \mathrm{P}$ that really affects a target tissue can be monitored as damages to DNA and proteins in these tissues upon exposure to $\mathrm{B}[\mathrm{a}] \mathrm{P}$. The three classes of biologically reactive $\mathrm{B}[\mathrm{a}] \mathrm{P}$ metabolites (radical cations, BPDE and o-quinones) can covalently bind to DNA, causing DNA adducts. For instance, the B[a]P-radical cation can form depurinating adducts with guanine and adenine that lead to apurinic/apyrimdinic (AP) sites [27]. However, radical cations have a short half life and are thus not likely to damage DNA in intact cells. ( \pm )-anti-BPDE can covalently bind to the DNA, preferably to guanine, resulting in the formation of the stereoisomeric bulky DNA adducts, due to the covalent interaction between the C10-position of BPDE and the 2-amino group $\left(N^{2}\right)$ of guanine (Figure 4). The predominant adduct (>90\%) found in ( \pm )-anti-BPDEexposed cells is (+)-trans-anti-BPDE- $N^{2}-d G$ [28-30]. Alternative interactions of BPDE with DNA include covalent binding at the $N^{7}$-position of guanine and to a lesser extent with the exocyclic amino groups of adenosine and cytosine [17]. B[a]P7,8-quinone can produce depurinating $\mathrm{N}^{7}$ adducts with guanine [31]. Next to forming covalent DNA adducts, $\mathrm{B}[\mathrm{a}] \mathrm{P}$ o-quinones can generate significant amounts of reactive oxygen species (ROS) via redox cycling [21] and can give rise to oxidative DNA lesions like 8-oxodeoxyguanine (8-oxodG), double and single strand breaks (Figure 3). B[a]P and trans-B[a]P-dihydrodiols have been shown to cause oxidative DNA damage in vivo and in vitro [32,33]. Additionally, the ROS produced may react with poly-unsaturated fatty acids to form lipid peroxidation products which can decay to electrophiles like 4-hydroxy-2-nonenal and 4-oxo-2-nonenal causing ethenoadducts and heptano-ethenoadducts, respectively [34,35]. 


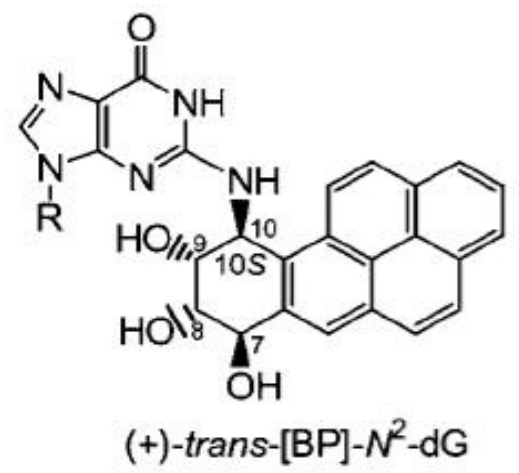

Figure 4. Structure of (+)-trans-anti-BPDE-N2-dG adduct.

(Adapted from Rechkoblit et al. [36].)

The bulky DNA adducts and oxidative damages introduced by the various reactive metabolites of $B[a] P$ can be removed by the nucleotide excision repair (NER) and base excision repair (BER) systems, as will be described in Section 2 of this Chapter. However, when these DNA adducts remain in the DNA, the incorrect nucleotide might be incorporated opposite the lesion, resulting in mutations that can be monitored as biomarkers of effect. Unlike DNA adducts, mutations are irreversible changes in the DNA structure that can not be repaired and will be passed on to the progeny of the originally mutated cell. The highly mutagenic DNAlesion (+)-trans-anti-BPDE- $N^{2}-\mathrm{dG}$ was shown to produce mostly $\mathrm{G} \rightarrow \mathrm{T}$ transversions, due to the incorporation of the wrong nucleotide adenine opposite the BPDE-dG adduct $[37,38]$. Furthermore, AP sites introduced by radical cations and DNA adducts caused by $B[a] P-7,8$-quinones, were also found to give rise to $G \rightarrow T$ transversions $[27,39]$. These transversions were seen in higher frequencies in lung cancers from smokers compared to non-smokers [40]. Moreover, good correlations were observed between hotspots of $B[a] P$-induced DNA adducts and $G \rightarrow T$ transversion hotspots in lung cancer $[39,41]$. Although, the formation of covalent $\mathrm{B}[\mathrm{a}] \mathrm{P}-\mathrm{DNA}$ adducts is known to be involved in the initiation of $\mathrm{B}[\mathrm{a}] \mathrm{P}$ carcinogenesis, the induction of $\mathrm{B}[\mathrm{a}] \mathrm{P}$-mediated oxidative DNA damage and its link to carcinogenesis has been reported as well [42]. In that case, the base guanine is the main target with 8-oxodG being the most frequent base lesion. Therefore, formation of 8-oxodG is an important biomarker of oxidative damage to DNA [43]. Furthermore, 8-oxodG exhibits ambiguous encoding properties in the biosynthesis of nucleic acids, behaving as guanine and thymine during replication and as guanine and uracil during transcription, because it can pair with cytosine and mispair with adenine in the syn conformation [43]. The miscoding properties of 8oxodG have been implicated in biological processes such as mutagenesis (producing predominantly $\mathrm{G} \rightarrow \mathrm{T}$ transversions as well) and carcinogenesis. This high incidence of $\mathrm{G} \rightarrow \mathrm{T}$ mutations in tissue/cellular DNA is generally interpreted as the primary biological effect of $\mathrm{B}[\mathrm{a}] \mathrm{P}$-induced carcinogenesis. 


\section{Chapter 1}

\section{DNA repair as a biomarker in molecular epidemiology}

In cases where the link between exposure and cancer is strong, measurement of biomarkers of exposure and effect can actually give an indication of cancer risk. This is for instance true for the agent aflatoxin, which has a causative role in liver cancer [44]. However, the link between markers of individual exposure and cancer risk can be affected by other steps that intervene between DNA damage and the onset of carcinogenesis. DNA repair is most certainly one of these steps, guarding against the transition of reversible DNA damages into irreversible changes in the nucleotide sequence. Since, DNA repair is known to play a crucial role in the protection against cancer, inter-individual differences in DNA repair capacity are bound to influence the vulnerability of a person to developing cancer. In this context DNA repair can be considered as an important marker of susceptibility in biomonitoring studies.

Various reliable, sensitive, robust and relevant DNA repair assays have been developed for use in human biomonitoring studies. Although, the validation stage is not complete yet, it seems likely that in vitro repair assays for the phenotypical assessment of both BER and NER will become standard tools in molecular epidemiology. Results obtained by these DNA repair assays are promising (as reviewed by Dusinska M. and Collins A.R. [45]) and overall they indicate that both NER and BER may be relevant biomarkers for assessing cancer risk in settings of environmental and occupational exposures.

Moreover, phenotypic biomarkers should be analyzed in parallel with genetic markers, as genetic variations in DNA repair genes may have significant effects on enzyme activity $[46,47]$. Genetic and phenotypic variations are both biomarkers of individual susceptibility and may yield more valuable information when studied together. Furthermore, the possible influence of gene-environment interaction on DNA repair, in particular the modulation of DNA repair by nutritional factors, should be investigated 


\section{DNA repair systems}

All living organisms are equipped with DNA repair systems that can cope with a wide variety of DNA lesions. Each pathway utilizes unique enzymatic mechanisms to detect and repair certain types of DNA damage (see Table 1). Most of these mechanisms take advantage of the base-paired structure of DNA in order to repair the damage. Humans possess several routes of DNA repair: direct reversal; excision repair that consists of both nucleotide excision repair (NER) and base excision repair (BER); mismatch repair; and double-strand break repair $[48,49]$.

Table 1. Overview of human DNA repair systems. (Adapted from Tyson et al. [49].)

\begin{tabular}{|l|l|l|}
\hline Repair pathway & Damage repaired & Sources of damage \\
\hline Direct reversal & Alkylated bases: O6-methyl-G & $\begin{array}{l}\text { Alkylating agents, } \\
\text { nitrosoureas, streptozotocin }\end{array}$ \\
\hline Base excision repair & $\begin{array}{l}\text { Oxidised bases alkylation, } \\
\text { abasic/apurinic/apyrimidinic } \\
\text { sites, single-strand breaks }\end{array}$ & $\begin{array}{l}\text { Reactive oxygen species } \\
\text { (ROS), alkylating agents, } \\
\text { spontaneous hydrolysis }\end{array}$ \\
\hline Nucleotide excision repair & Bulky helix-distorting lesions & $\begin{array}{l}\text { UV light, cigarette smoke, } \\
\text { dietary factors (aflatoxin, } \\
\text { PAHs (B[a]P)) }\end{array}$ \\
\hline Mismatch repair & $\begin{array}{l}\text { Mismatched base pairs, small } \\
\text { insertion loops }\end{array}$ & $\begin{array}{l}\text { Replication errors, minor } \\
\text { base modifications } \\
\text { (oxidation, alkylation) }\end{array}$ \\
\hline Double-strand break repair & $\begin{array}{l}\text { Double-strand breaks, DNA } \\
\text { cross-links }\end{array}$ & $\begin{array}{l}\text { lonising radiation, cross- } \\
\text { linking agents (cisplatin), } \\
\text { replication errors }\end{array}$ \\
\hline
\end{tabular}

The importance of DNA repair for maintaining normal genomic integrity and prevention of neoplastic phenotype is underscored by the fact that defective repair is linked to increased susceptibility of cells to toxic, mutagenic, and carcinogenic effects of exposure to environmental carcinogens [50]. This is for example illustrated by the occurrence of rare autosomal recessive disorders such as xeroderma pigmentosum (XP). Mutations in XP genes lead to defective NER and increased cancer rates mainly due to hypersensitivity to UV [50,51].

Despite the repair activity of the various enzymatic systems as well as the presence of cell-cycle checkpoints, repair often does not occur before replication of the damaged DNA is attempted. Fortunately, cells have developed mechanisms that deal with such situations and can bypass the damaged site, allowing synthesis of nascent DNA strand opposite the blocking lesion [48]. In other words, some of the unrepaired DNA damage can be tolerated via DNA damage tolerance mechanisms. However, when the amount of DNA damage is getting too extensive to be efficiently 


\section{Chapter 1}

processed by DNA repair or DNA damage tolerance mechanisms, the cell will initiate programmed cell death (apoptosis) to eliminate itself, thereby preventing pathological conditions (Figure 5).

It is beyond the scope of this thesis to describe all the above mentioned DNA repair processes in detail. Therefore, only the DNA repair and damage tolerance mechanisms that are relevant for the better understanding of the following Chapters will be depicted in the next paragraphs.

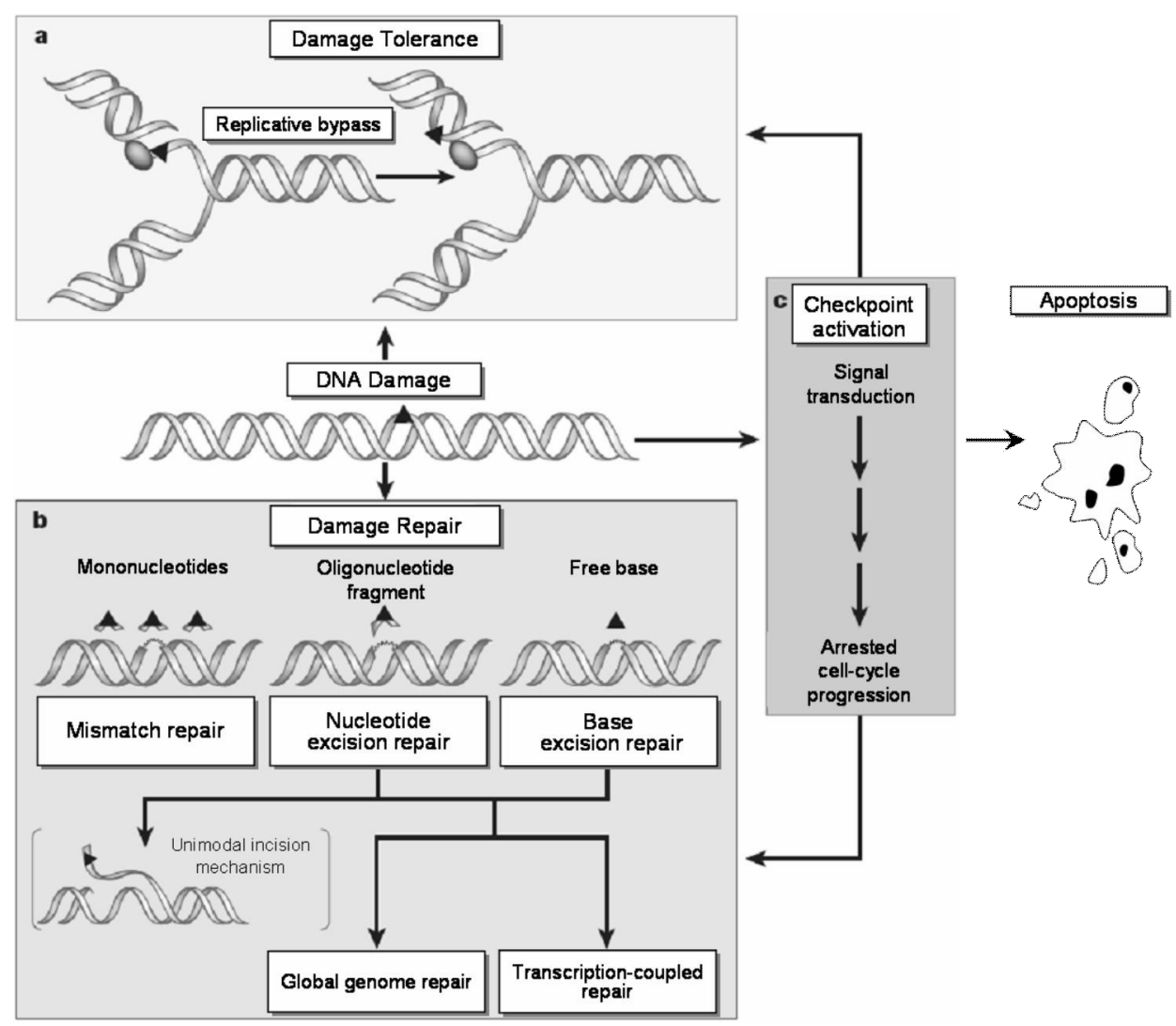

Figure 5. Schematic overview of the responses to DNA lesions. DNA damage $(\boldsymbol{\Delta})$ will either be tolerated (a) or repaired (b). A complex network of signalling pathways arrests the cell cycle allowing DNA damage repair/tolerance to occur, or it may ultimately lead to programmed cell death in situations of massive DNA damage (c). (Adapted from Friedberg [48].) 


\section{Base excision repair}

Base excision repair (BER) recognizes and removes relatively small modified bases that do not disrupt the DNA double helix. The BER pathway is mainly involved in the repair of apurinic/apyrimidinic (AP) sites, where the base is missing from the DNA backbone, but also oxidized, deaminated and alkylated bases that can cause mispairing and induce mutations are removed [52].

The BER system involves the joint action of various enzymes, of which the most important ones are the DNA glycosylases. Humans possess eleven different glycosylases that can each recognise a specific type of altered base in DNA and catalyse the removal of this mismatch by removing the damaged nucleoside [53]. For example, the mammalian enzyme 8-oxoguanine DNA glycosylase 1 (OGG1) is responsible for the removal of 8-oxoguanine lesions [54,55]. Repair by BER occurs in three stages: 1) repair is initiated by a DNA glycosylase that specifically recognizes a damaged base; 2) followed by incision of the phosphodiester backbone by an AP endonuclease enzyme or by the glycosylase itself, generating an AP site; 3) resynthesis of DNA by DNA polymerase $\beta$ or $\delta / \varepsilon$, ending with ligation. In the second stage, BER removes short stretches of DNA of which the length is dependent on the subpathway that is involved in the repair of the lesion: the shortpatch BER pathway removes a single nucleotide; while in the long-patch BER an additional 2 to 13 nucleotides are removed [56].

It is interesting to note that no diseases resulting from a defective BER have been described so far. Reactive oxygen species (ROS) are so ubiquitous that oxidative damage is inevitable and mutations that disable DNA repair pathways might be lethal in embryo. On the other hand, backup pathways exist for the removal of oxidative lesions, so that mutations have no major effect in terms of human disease. For instance, it has been shown that NER can function as a backup system for BER, in cases where massive oxidative stress causes high levels of oxidative DNA damage [57-59].

\section{Nucleotide excision repair}

Nucleotide excision repair (NER) is a complex process capable of removing a broad spectrum of DNA-helix distorting lesions induced by UV (e.g. pyrimidine dimers) and by numerous chemical compounds like benzo[a]pyrene [60]. Moreover, in case of extensive oxidative DNA damage, NER is considered to be a back-up system for BER $[57,58]$. NER involves over 30 distinct proteins that function as a large complex called the nucleotide excision repairosome [48]. This complex facilitates the excision of damaged nucleotides by generating incisions ' 5 and 3 ' of the lesion and removing a fragment of about 30 nucleotides long.

Like BER, repair initiated by NER can be divided into three general steps: 1) recognition of DNA damage; 2) single strand incisions and excision of the lesioncontaining DNA fragment; and 3) DNA repair synthesis/ligation. 


\section{Chapter 1}

Global genome repair

Transcription-coupled repair
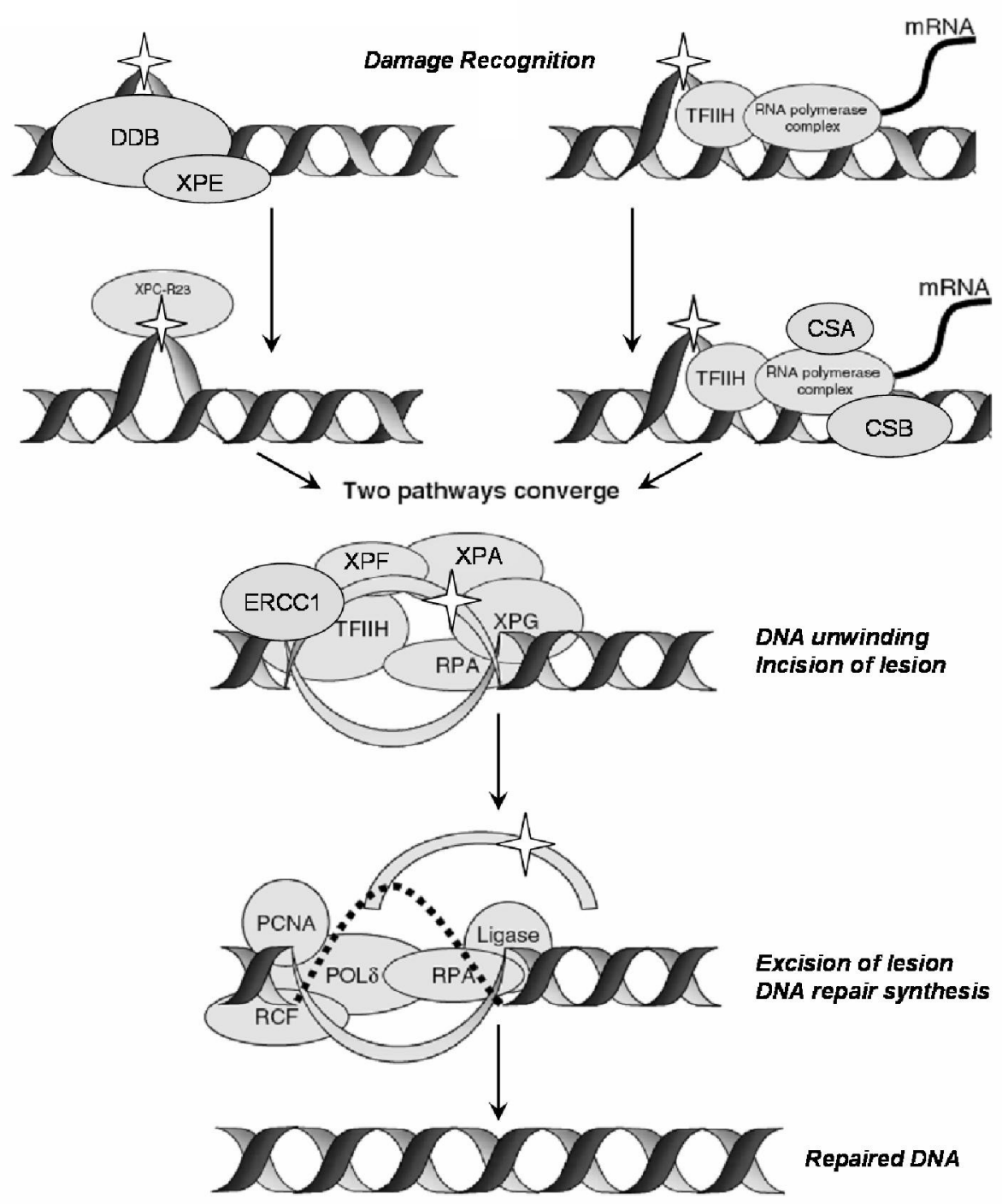

Figure 6. Overview of the human nucleotide excision repair pathway. Detailed information about this process can be found in the text. Bulky helix distorting DNA adduct $(\downarrow)$. DDB, damaged DNA binding protein; XPE, XPC, XPA, XPG, XPF, xeroderma pigmentosum complementation groups $\mathrm{E}, \mathrm{C}, \mathrm{A}, \mathrm{G}$ and $\mathrm{F}$; CSA and CSB, Cockayne syndrome complementation group $A$ and $B$; TFIIH, transcription factor $11 \mathrm{H}$; ERCC1, excision repair cross-complementing rodent repair deficiency complementation group 1 ; RPA, replication protein A; PCNA, proliferating cell nuclear antigen; RCF, replication factor C; POL $\delta$, DNA polymerase $\delta$. (Adapted from Tyson and Mathers [49]) 
The rate limiting steps in NER are damage recognition and incision, as ATP is required for the cleavage and opening of the damaged DNA strand [56]. Furthermore, NER can operate via two subpathways: global genome repair (GGR) acts on DNA lesions in non-transcribed regions across the genome; and transcription coupled repair (TCR), which is a specialized pathway coupled to active transcription and directed to DNA lesions in the transcribed strand of a gene.

Two proteins have been identified and implicated in the lesion recognition step of GGR-NER: the xeroderma pigmentosum group $C(X P C)$ protein, in complex with the UV excision repair protein RAD23 homologue $B$. In addition, mammalian cells express the DNA damage binding (DDB) proteins DDB1 and DDB2 (a.k.a. XPE) that form a heterodimer and promote the damage recognition process in GGR $[61,62]$. This DDB complex binds the damaged DNA with much higher affinity and specificity than XPC $[63,64]$. Moreover, it is suggested that ubiquitylation of DDB results in its dissociation from the lesion, promoting lesion transfer to XPC and subsequent initiation of NER [64]. The XPC-RAD23B then binds directly to the lesion, causing local unwinding so that other XP factors can be loaded onto the damaged site. As such, the XPC-RAD23B complex is essential for the formation of the NER incision complex.

In the TCR subpathway damage recognition and removal is thought to be initiated by the blockage of RNA polymerase II by a DNA lesion during transcription. TCR requires additional proteins that are not needed for GGR, including CSA and CSB that were found to be mutated in the human DNA repair disorder Cockayne Syndrome (CS) [65]. CSA has an ATPase activity. CSB has homology to proteins that are involved in chromatin remodelling. Both proteins have been shown to exhibit interactions with basal transcription factors and excision repair proteins. Although, the precise underlying mechanisms still remain unclear, the CSA and CSB proteins probably attract other essential repair proteins to the site of DNA damage, or they might assist in eliminating stalled transcription complexes from the damaged sites so that repair can occur [66].

After the initial recognition of the DNA damage by GG-NER or TC-NER pathways, the two pathways converge. Both modes of NER require the activities of XPA and replication protein A (RPA), XPB, XPD, XPF/ERCC1 and XPG. XPA binds to the damaged DNA strand while RPA, a single-strand binding protein, envelops the undamaged strand. Next DNA is unwounded by the helicase enzymes XPB (unwinding $3^{\prime}$ to $5^{\prime}$ ) and XPD (unwinding $5^{\prime}$ to $3^{\prime}$ ) that act in NER as part of the general transcription complex TFIIH. Subsequently the damaged DNA strand is incised ' 3 ' and ' 5' of the lesion by XPG and the XPF/ERCC1 heterodimer, respectively, releasing a damage-containing oligomer of 24-32 bases long. DNA polymerase $\delta / \varepsilon$ then fills in the resulting gap, using the free 3 '-terminus and the complementary DNA strand as a template. Finally, DNA ligase seals the newly synthesized DNA strand to the parental strand [67]. 


\section{Chapter 1}

\section{DNA damage tolerance pathways}

Although DNA repair processes and cell cycle checkpoint controls are fully active, some DNA lesions may persist in the genome. If these lesions block the progression of DNA polymerases, the replication forks may collapse, which can lead to the formation of double strand breaks and/or chromosome rearrangements that can subsequently induce cell death. To prevent such deleterious effects, cells possess damage tolerance systems that are able to complete replication in the presence of persisting DNA damages.

In general, DNA damage tolerance is controlled by the RAD6-pathway, which encompasses several components of the ubiquitin system [68]. The RAD6 gene product is a ubiquitin-conjugating enzyme that forms a complex with Rad18, which is a single-stranded DNA-dependent ATPase. Once the complex is formed Rad18 will bind to ssDNA at the stalled replication fork and target Rad6 to the site of damage $[69,70]$. Subsequently, Rad6 conjugates a single ubiquitin moiety to the substrate protein PCNA (= proliferating cell nuclear antigen), a DNA polymerase clamp. As for the following steps, DNA damage tolerance can occur via two different mechanisms: translesion synthesis (TLS) or error-free bypass (Figure 7). The first mechanism is considered error-prone as it uses specialized translesion polymerases that may insert incorrect nucleotides across a damaged site, while the second pathway is error-free because it uses the information of the undamaged sister duplex at the replication fork [71]. It is suggested that the Rad6-Rad18 complex is involved in the first step of both mechanisms. Via which mechanism DNA damage tolerance will occur, depends on the type of ubiquitination. It appears that PCNA will interact with polymerases involved in the TLS pathway, when it is monoubiquitinated by Rad6 [68,72]. On the other hand, poly-ubiquitination of PCNA via lysine63-linkage seems to facilitate error-free bypass of the lesion. The complex interplay between these two pathways and the process via which it is determined if mono- or poly-ubiquitination of PCNA will occur is not well understood, but both pathways are able to inhibit genomic instability and thus prevent cell death.

In addition to the Rad6-Rad18 complex and PCNA, other proteins involved in the error-free bypass pathway are the Ubc13/Mms2 heterodimer having ubiquitinconjugating activities, the ssDNA-dependent ATPase Rad5 that recruits Ubc13/Mms2 to the site of damage, and polymerase Pol $\delta$. Thus, after conjugation of a single ubiquitin moiety to PCNA by Rad6, Ubc13/Mms2 catalyses the elongation via ubiquitin-linkage through lysine63. It has been suggested that these lysine63linked poly-ubiquitin chains may be part of a novel signal transduction mechanism, directing DNA damage tolerance into the error-free bypass pathway and recruiting template switching proteins [75]. 


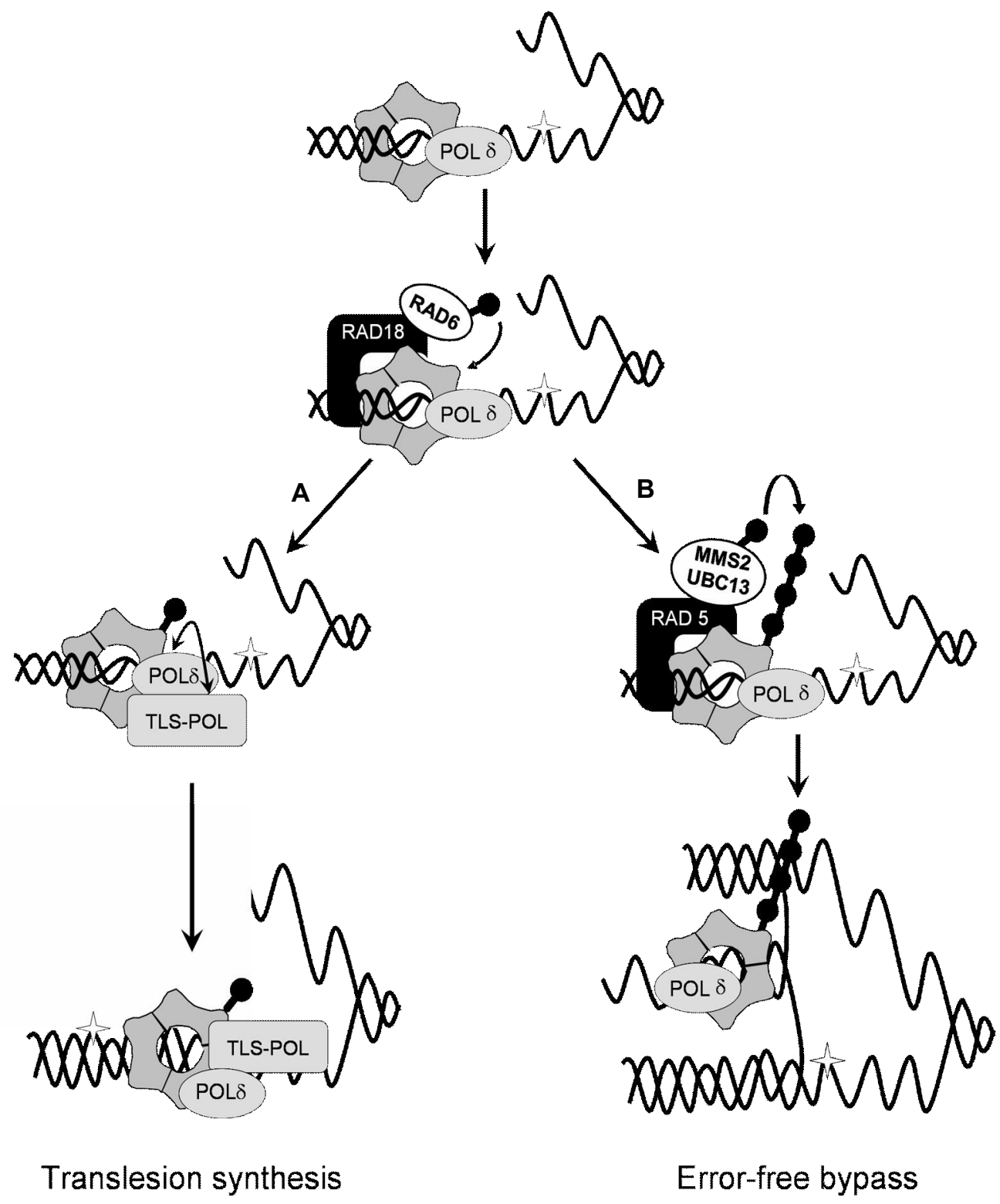

Figure 7. DNA damage tolerance mechanisms. The replication fork arrests due to a DNA lesion ( $\vec{\gamma}$ ). A) Mono-ubiquitination ( ubiquitin moiety) of PCNA by Rad6-Rad18 activates the translesion synthesis pathway as the TLS-polymerases use the damaged DNA as template. B) Poly-ubiquitination of PCNA by Rad6-Rad18 and Ubc13/Mms2Rad5 complexes leads to the error-free bypass of the lesion, as it involves the regression of the replication fork and a template switch to the undamaged sister strand. (Adapted from Ulrich [73] and Chiu et al. [74]) 


\section{Chapter 1}

In contrast to the error-free bypass mechanism, TLS directly copies the damaged DNA template during replication. Copying the damaged template requires replacement of the stalled DNA polymerase by specialized low-fidelity and often error-prone DNA polymerases [37]. It seems that these specialized DNA polymerases have no proofreading function, indicating that TLS is inevitably accompanied by mutations at frequencies that are dependent on the type of DNA damage, as well as the specific polymerase that is involved [76]. Most of these lowfidelity DNA polymerases have recently been identified and are collectively know as Y-family DNA polymerases, including Pol $\eta$, Polı, Poк and Rev1. These polymerases are either error-prone or error-free, depending on the type of DNA damage they encounter. An additional DNA polymerase involved in TLS (but no member of the $\mathrm{Y}$ family) is Pol $\zeta$, which is very inefficient in inserting nucleotides opposite DNA lesions. However, Pol $\zeta$ readily extends from deoxynucleotides that have been inserted by other TLS polymerases, promoting the mutagenic bypass of DNA lesions [77].

One of the key factors of $\mathrm{B}[\mathrm{a}] \mathrm{P}$-induced carcinogenesis is the formation of mutagenic anti-BPDE- $N^{2}-d G$ DNA adducts. Since TLS directly copies the damaged DNA template in an error-prone way, it represents a major mechanism of BPDEDNA adducts induced mutagenesis. Especially Pol $\eta$ is known to bypass ( \pm )-antiBPDE- $N^{2}-\mathrm{dG}$ adducts in an error-prone way, promoting mutagenesis by predominantly inserting adenosine bases opposite the lesion, which will lead to the induction of $G \rightarrow T$ transversions $[37,38]$. On the other hand, Polk is reported to act in an error-free way. Thus TLS past BPDE-DNA adducts can either be error-free or error-prone, depending on whether the correct or incorrect nucleotide is incorporated opposite the lesion. Mutagenesis is suppressed when TLS occurs in an error-free way, whereas error-prone TLS will promote mutagenesis.

\section{Methodological approaches to measure DNA repair}

Although, the efficiency of DNA repair processes is suggested to be an important determinant of individual susceptibility to cancer, surprisingly little is known about the inter-individual variations in DNA repair capacity. It is obvious that genetic and dietary factors may influence DNA repair, but in order to elucidate these effects, simple, fast and reliable assays to measure DNA repair are required. Several methodological approaches to asses DNA repair have been described in scientific literature and were applied in several biomonitoring studies [78,79]. 


\section{Indirect assays}

The most commonly used assay to measure DNA repair (particularly used in casecontrol studies) involves treatment of stimulated lymphocytes with typical DNAdamaging agents like ionizing radiation, BPDE or bleomycin and scoring of the resulting chromosome aberrations (CA) [80]. This is a relatively simple test in which a higher number of CA induced by the genotoxic agent is assumed to express higher "mutagen sensitivity" and thus lower DNA repair. Therefore, this assay is not a direct measure of DNA repair, but the magnitude of the responses might be influenced by DNA repair. Another limitation of this approach is that the general endpoint of chromosome damage could also reflect processes other than DNA repair, such as antioxidant protection and cell cycle kinetics [81].

An alternative method that is traditionally used for DNA repair is the unscheduled DNA synthesis (UDS) assay [82], which is based on the incorporation of $\left[{ }^{3} \mathrm{H}\right]$ thymidine into the cellular DNA after treatment with a genotoxic agent, as measured in the absence of replication. The UDS assay is efficient in demonstrating repair of UV-induced damages provided that the applied doses are sufficiently high, though, it is less effective for the detection of the far smaller gaps occurring during BER.

Another indirect approach is the host cell reactivation assay [83] that has been used mainly for the estimation of NER. DNA damage is not introduced directly into the cells, but brought into the cell by means of transfection with a plasmid containing a reporter gene (e.g. luciferase gene) that has been damaged by UV or BPDE. The ability of cells to repair the lesion in the plasmid can then be estimated from the enzyme activity of the reporter gene product, resulting from the restoration of transcription of the reporter gene. However, the outcome of this assay might be influenced by the efficiency of transfection. Nevertheless, it has been successfully used to investigate inter-individual differences in DNA repair and to study the effect of dietary factors on DNA repair capacity $[84,85]$.

\section{Direct measurement of cellular repair}

The most straight forward approach to measure DNA repair capacity is to induce DNA damage in cells and subsequently monitor the speed of repair/removal of these lesions over time. One direct method for the quantitative assessment of DNA excision repair was developed by Stierum et al. [86], applying ${ }^{32} \mathrm{P}$-postlabelling. Total binding of radiolabeled ( \pm )anti-BPDE to DNA in human peripheral lymphocytes and its subsequent removal had been reported before $[87,88]$, but the ${ }^{32} \mathrm{P}$ postlabelling-method enables the direct investigation of repair of the main BPDEDNA adduct that is involved in $\mathrm{B}[\mathrm{a}] \mathrm{P}$-induced mutagenesis, namely $( \pm)$ anti-BPDE$N^{2}-d G$.

An alternative way to measure damage removal over time is by means of the comet assay (single cell gel electrophoresis), which in its original form measures DNA strand breaks. Rejoining of DNA strand breaks introduced by ionizing radiation or agents such as $\mathrm{H}_{2} \mathrm{O}_{2}$ is known to be a rapid process in most cell types, with a 


\section{Chapter 1}

half-life of only a few minutes. However, freshly isolated lymphocytes appear to repair these lesions more slowly, taking up to several hours to repair $\mathrm{H}_{2} \mathrm{O}_{2}$-induced damages [89]. This assay can be improved by incorporating an additional step in which the nucleoid DNA is incubated with a lesion-specific endonuclease. Two enzymes can be used to measure specifically oxidative DNA damage; endonuclease III for the detections of oxidized pyrimidines, and formamidopyrimidine DNA glycosylase (FPG) recognizes the oxidized purine 8oxoguanine and ring-opened purines [90,91]. The enzyme endonuclease $V$ can be used for the detection of UV-induced pyrimidine dimers [92]. However, also the repair by these lesion-specific endonucleases occurs relatively slowly in isolated lymphocytes [93].

Overall, these approaches are highly sensitive in detecting low levels of DNA damage, though, the need for prolonged incubations as seen for lymphocytes is a drawback regarding its applicability in molecular epidemiological studies.

\section{In vitro repair assays}

As an alternative to assess cellular repair, in vitro repair assays have been developed, which depend on the capacity of a cell extract to recognize and incise substrate DNA containing specific lesions. The whole-cell extract can be prepared from lymphocytes, grinded tissue or cultured cells, by 'snap-freezing' and lysis with Triton X-100. At this moment, there are three distinct types of in vitro repair assays.

One of these approaches uses as substrate a closed circular plasmid that contains a specific lesion. When incubated with the whole cell extract, repair enzymes within this extract can incise the plasmid close to the lesion and resulting nicked or closed plasmids can be separated by gel electrophoresis [94]. In an alternative version of this plasmid assay, the cell extract will be incubated with the plasmid in the presence of ${ }^{32} \mathrm{P}$-labelled deoxyribonucleoside triphosphates and repair can be estimated by the incorporation of radioactive precursors into a repair patch [95]. In this way the plasmid assay measures the overall repair starting from incision to repair synthesis.

Furthermore, the cell extract can be incubated with an oligonucleotide that is constructed with a specific DNA lesion and a terminal radioactive or fluorescent tag $[96,97]$. The repair enzymes in the extract will cut the oligonucleotide at the damaged site, causing the release of the label, which can be measured as an indicator for DNA repair using conventional gel electrophoresis.

The third type of in vitro repair assay is an modified version of the comet assay that was originally designed to measure BER [98]. In this assay the DNA substrate consist of gel-embedded nucleoids from cells that were pre-treated with the photosensitizer Ro 19-8022 plus light to induce 8-oxoguanine lesions. Incubation of these substrate nucleoids with cell extracts will allow the initial steps of BER to occur, i.e. damage recognition and incision, resulting in single strand breaks that can be detected by the comet assay. An increase of DNA fragments in the comet tail reflects the DNA repair capacity of the cell extract. 
These in vitro repair assays are versatile methods that can be readily adapted to measure excision capacities of extracts of human cells or tissues on DNA substrates containing various lesions, e.g. substrates exposed to UV, X-rays or MMS. Recently, a modified comet-based in vitro repair assay to measure the activity of NER on substrates containing BPDE-induced DNA adducts, has been developed at our laboratory [see Chapter 2]. Overall, these assays provide powerful tools to further substantiate the role of DNA repair capacity in the development of cancer and to provide answers to important research questions on the influence of geneenvironment interactions on DNA repair.

\section{Inter-individual variation in DNA repair capacity}

Each individual seems to have a characteristic level of repair activity and large interindividual variations were observed in healthy populations. Qiao et al. showed a 4 to 7-fold variation in NER capacity in 102 healthy subjects, as measured by the host cell reactivation assay [84]. Furthermore, using the same assay, a 10-fold interindividual variation in NER was found in 63 healthy volunteers recruited to the Dietary Antioxidant Repair Trial [99]. Factors that can contribute to these interindividual variations in DNA repair are genetic influences like polymorphisms in DNA repair genes, variations in environmental exposure to carcinogens and nutritional factors (see Figure 1).

\section{Nutritional modulation}

Dietary habits are recognized as an important exogenous factor that may influence cancer risk and tumor behaviour. A lot of effort has been put into defining the chemopreventive effects of dietary compounds. Case-control studies reported overall evidence for the cancer protective effects of vegetables and fruits [100]. However, more recent large prospective studies failed to show the effects seen in case-control studies performed in the mid-1990s and have made the overall evidence that vegetables and fruits protect against cancer, somewhat less impressive. A report of the WCRF/AICR summarized recently all the available evidence on whether certain types of vegetables and fruits in general protect against a number of cancers [101].

Since epidemiological studies can only provide evidence of a correlation between certain nutrients/diets and the occurrence of cancer, the evidence of causal relationships between food, nutrition and cancer will always be incomplete. Therefore, the development and use of intermediate biomarkers of chemical carcinogenesis, such as DNA damage and repair, is of great importance in elucidating the role of nutrition in carcinogenesis and in revealing the molecular mechanisms involved. Many studies have been conducted to elucidate the effect of diet on the levels of DNA damage, as it is considered to be the initial step of chemical carcinogenesis (recent reviews $[45,102,103])$. However, DNA lesions can 


\section{Chapter 1}

be converted to mutations only if not adequately repaired and therefore studies regarding an individual's DNA repair capacity would be of equal importance.

Although the number of studies on the dietary modulation of DNA repair is limited and there is little direct evidence for biological mechanisms through which diet may modulate DNA repair processes, some possible mechanisms have been proposed. In general, DNA repair could be modulated by diet due to its known effects on transcription, mRNA stability and translation, protein stability and trafficking. For instance, selenium (Se) compounds as well as toxic metal ions (e.g. Cd) present in food, can affect DNA repair by altering the binding activity of the so called zinc $(\mathrm{Zn})$ finger proteins $[104,105]$. The group of $\mathrm{Zn}$ finger proteins consist of DNA binding proteins like transcription factors and DNA repair proteins that contain $\mathrm{Zn}$ atoms complexed through cysteine and/or histidine residues, making up the $\mathrm{Zn}$ finger domain that is involved in DNA binding. Se and the toxic metal ions $\mathrm{Cd}, \mathrm{Cu}$, $\mathrm{Ni}$ and $\mathrm{Co}$, were shown to inactivate the DNA repair protein XPA by displacement of $\mathrm{Zn}$ from the protein [104-106]. Thus, an adequate intake and bioavailability of $\mathrm{Zn}$ is required to prevent disruption of functional domains and to assure the optimal functioning of DNA binding proteins like XPA.

Furthermore, DNA repair can be modulated by diet via hypermethylation of CpG islands (short stretches of DNA that contain a high frequency of the CG sequence) in promoter regions of repair genes, resulting in gene silencing. Folate as a methyl donor can alter DNA methylation and thereby influence the expression of specific DNA repair genes $[107,108]$. Other dietary compounds like vitamin C, Zn and Se were found to alter DNA methylation as well [109].

An additional important mechanism by which diet may influence DNA repair is through redox regulation. For instance, exposure to certain environmental contaminants in food can lead to the production of reactive oxygen species (ROS), inducing oxidative DNA damage and oxidative stress. Toxic metals like mercury, arsenic, lead and cadmium were reported to inhibit DNA repair by increasing the production of ROS [110,111]. Furthermore, as mentioned above, the aldo-keto reductase pathway of $\mathrm{PAH}$ activation to o-quinones provides a route for ROS generation, amplifying the production of e.g. hydroxyl radical $\left({ }^{\circ} \mathrm{OH}\right)$, superoxide anion $\left(\mathrm{O}_{2}{ }^{--}\right)$and hydrogen peroxide $\left(\mathrm{H}_{2} \mathrm{O}_{2}\right)$ via redox cycling (see Figure 3 ). In addition, exposure to PAHs was observed to be associated with a significant decrease in repair efficiency in human volunteers [112]. Once formed, ROS can generate excess oxidative stress and overwhelm the cellular defense mechanisms. Thereby, ROS can activate signal transduction pathways and transcriptionally regulate DNA repair genes. Furthermore, exogenous nitric oxide and peroxynitrite have been shown to inhibit OGG1 [113] and DNA ligase [114] activity. Moreover, lipid peroxidation products (e.g. 4-hydroxynonenal, malondialdehyde) have been reported to inhibit NER most likely by direct oxidative attack and inactivation of NER proteins $[115,116]$.

Dietary antioxidants can counteract the oxidative stress-induced inhibition of DNA repair either through scavenging of ROS, or by stimulating endogenous 
defences via signal transduction pathways. These defence systems include enzymatic antioxidants like superoxide dismutases (SOD) and catalase, the most abundant antioxidant glutathione (GSH), and other non-enzymatic antioxidant nutrients like vitamin $\mathrm{E}$ and polyphenols. They exert their antioxidant actions by the inactivation of ROS and binding of transition metals [117,118]. GSH was observed to reverse the metal-induced inhibition of DNA repair [119]. Furthermore, dietary antioxidants like vitamins B6, C and E, zinc, taurine, N-acetylcysteine, and alphalipoic acid, have been shown to interrupt or minimize ROS formation and prevent the damaging effects of lead exposure in a number of animal studies [111]. Moreover, some enzymes involved in cellular defence are controlled at the transcriptional level through the binding of the redox sensitive transcription factor AP-1 (activator protein-1) in the promoter region of their genes. ERCC1, a critical gene within the NER pathway, also contains an AP-1 like binding site [120], which can be regulated by the intracellular redox status. Moreover, some antioxidants can also exert intracellular pro-oxidant effects. In that way they can stimulate/inhibit ROS and modulate the redox status of the cell, resulting in changed gene expression of DNA repair genes. In this context antioxidants are thus capable of regulating DNA repair capacity by altering the redox status.

So far, only a few studies have investigated the beneficial effects of dietary compounds on DNA repair processes (reviewed in [49]). Several of these studies looked into dietary modulation of BER or the repair of oxidative lesions. For example, a three weeks intervention with one, two or three kiwifruits resulted in a significant increase of OGG1 activity [121]. Only one study reported the effect of dietary factors on NER, observing an association between low dietary folate intake and reduced DNA repair capacity [85]. Moreover, it has been shown that dietary supplementation with cooked carrots increased the repair of $\mathrm{H}_{2} \mathrm{O}_{2}$-induced lesions, whereas supplementation with similar amounts of $\alpha$ - and $\beta$-carotene provided as capsules had no effect on repair capacity [122]. This effect may be due to interactions between antioxidants and other compounds, which render antioxidants more bioactive in a food matrix [123]. Therefore, it can be suggested that whole food products rather than single bioactive components have beneficial effects on DNA repair and subsequently act against cancer.

\section{Genetic polymorphisms}

Another factor which can influence DNA repair efficiency is an endogenous one, namely the genetic makeup of an individual. The human genome project revealed that about $99.9 \%$ of human DNA sequences are the same between individuals. Only the remaining small part of approximately $0.1 \%$ of the human genome can vary in sequence between individuals [124]. About $90 \%$ of these variations in the human genome consist of single nucleotide polymorphisms (SNPs). DNA sequence variations are considered as SNPs when a single nucleotide (A, T, C or G) in the genome sequence is altered and the frequency of the variant allele is at least $1 \%$ of 


\section{Chapter 1}

the population. Single nucleotide polymorphisms that fall within coding sequences of genes can give rise to a protein that has an amino acid substitution or is truncated, leading to changes in activity, localization, or stability $[125,126]$. SNPs that do not occur in protein-coding regions may still have biological consequences. For instance, polymorphisms in promoter regions may affect the regulation and level of expression of a protein, while SNPs in untranslated regions or near intron-exon junctions may disturb the mRNA structure and translational process or cause alterations in mRNA splicing, respectively [127]. These differences in genetic variations can affect an individual's phenotype and may predispose people to diseases like obesity, cancer, and cardiovascular disease. Moreover, the genetic profile of a person may affect their susceptibility towards exposure to chemical carcinogens.

The majority of genes encoding for proteins involved in DNA repair processes are polymorphic [128]. Common SNPs in DNA repair genes have been associated with cancer risk [129-131]. Several studies showed an association between the GGgenotype of the common XPA polymorphism $23 A \rightarrow G$ and a reduced risk for lung cancer [47,132]. Furthermore, carriers of the Asp/Asn or Lys/GIn amino acid substitution in the codons 312 and 751 of XPD respectively, were at higher risk of lung cancer than homozygous wild types [132]. In addition, several genetic polymorphisms in NER and BER genes were shown to modulate the levels of chromosomal damage, measured as micronucleus frequencies [133-135]. Moreover, the same SNPs that appear to influence cancer risk have been associated with changes in DNA repair activity. For instance, Wu et al. observed less efficient NER to occur in individuals carrying the A-allele of the common XPA polymorphism $23 A \rightarrow G$ in the 5'-untranslated region [47]. Similar for polymorphisms in the XPD gene; carriers of the variant alleles of Asp312Asn and Lys751G/n showed reduced NER capacities [46] and increased levels of DNA adducts [136]. Genetic polymorphisms in DNA repair genes could thus affect an individual's susceptibility towards cancer, though, it is still not completely elucidated whether polymorphisms in various NER genes have a profound impact on the phenotypical activity of this repair pathway.

Still, studies regarding associations between SNPs and cancer risk or DNA repair are sometimes inconclusive. These differential findings may be attributed to differences in study size and statistical power, as larger studies having greater power can detect smaller effects. On the other hand, the interaction between genetic profile and environmental factors like diet could be of influence as well, so that certain associations between genotype and phenotype only appear in specific environmental settings. 


\section{Gene-environment interactions}

Many common diseases in humans are not simply caused by a genetic variation within a single gene, but are influenced by complex interactions among multiple genes as well as environmental and lifestyle factors. Several studies show that genetic polymorphisms in biotransformation, DNA repair and oxidative stress genes are able to modulate the antioxidative or chemopreventive effects of dietary interventions. For instance, in a dietary intervention study involving 168 healthy volunteers consuming blueberry/apple juice, Wilms et al. observed GSTT1 wild-type subjects to benefit most from the protecting effects of the antioxidant treatment against oxidative DNA damage [137]. Palli et al. reported a strong inverse association between DNA adduct levels and vegetable intake in subjects carrying the GSTM1 null genotype only [26]. Furthermore, a few other studies have investigated the interrelationships between genetic polymorphisms in DNA repair genes and fruit/vegetables intake in relation to cancer risk. Gils et al. reported an association of low intake of dietary antioxidants with an increased risk of prostate cancer only among carriers of the homozygous wild-type "damage protective" genotype for XRCC1-Arg399GIn [138]. Furthermore, an increased risk of lung cancer was observed to be associated with low intake of alpha-tocopherol supplement among carriers of the variant allele of XPD-Lys751GIn [139].

As such, it is suggested that the response to environmental factors like diet may often depend on specific genetic polymorphisms. Therefore, studies that investigate interactions between relevant genetic polymorphisms and phenotypic responses will be helpful in the assessment of susceptible groups and the selection of subgroups among the general population that will benefit more from specific dietary interventions. However, most of these studies are focussed on cancer risk and are not directly linked to differences in DNA repair. Thus, further investigations into the joint effect of genetic and dietary factors on the phenotypic DNA repair capacity will be required. Studies within this area will be helped by the development of fast, simple and reliable technologies that can assess DNA repair capacities, which will provide powerful tools to further substantiate the role of DNA repair in the development of cancer and human health. 


\section{Chapter 1}

\section{Aim and outline of the thesis}

DNA repair processes play an important role in the maintenance of the genomic integrity. Thus, up-regulation of DNA repair processes could protect the cells against genotoxic assaults and may prevent the occurrence of mutations. Considering the prominent role of DNA damage and repair in health and disease, further research on the modulation of DNA repair is urgently needed. Unfortunately, data in the scientific literature on dietary modulation of DNA repair are rare, especially for NER. Still, many human cancers are directly related to exposure to chemical carcinogens, such as PAHs, that exert their carcinogenic action through formation of DNA adducts that are generally removed by NER. Observed inter-individual variations in NER capacity were in the range of $\sim 4$ to 10 -fold, whereas some individuals showed almost negligible NER capacity [140], which might lead to an accumulation of DNA lesions, increasing the risk of mutations and cancer development. Moreover, defects in NER are known to be associated with several human autosomal recessive hereditary disorders like xeroderma pigmentosum (XP). These XP patients exhibit extreme sensitivity towards UV exposure and have a marked higher risk for skin cancer. Thus, NER plays an important role in the prevention of carcinogenesis. Furthermore, in vitro as well as in vivo studies suggest that modulation of the redox status by prooxidants and dietary antioxidants may modulate DNA repair capacity, involving upor down-regulation of enzymes that play a role in repair processes [43,121,141,142]. Taken together, these observations have led to the hypothesis that reactive oxidants like ROS have a prominent mediating role of in the effectiveness of DNA repair mechanisms, and that a modulating effect of antioxidants may occur via the prevention of ROS induced oxidative stress and DNA damages. Therefore, the aim of the present thesis is to investigate whether nutritional redox modulation concomitantly modulates nucleotide excision repair capacity, focussing on both phenotypic and genotypic markers and comprising the full range of studies with cells in vitro, with experimental animals as well as with ambulant human volunteers.

To this end, as a first approach, a modified comet assay was developed to phenotypically assess inter-individual differences in nucleotide excision repair capacities. As described in Chapter 2, this approach involves measurement of the capacity of human lymphocyte extracts to perform the initial steps of NER, i.e. damage recognition and incision, on DNA substrates carrying BPDE-DNA adducts. This in vitro repair assay was validated by comparison with other methodologies like

${ }^{32} \mathrm{P}$-postlabeling for the assessment of bulky DNA adduct removal, as well as by using extracts from NER deficient (XPA and XPC) fibroblasts.

Subsequently, the newly developed in vitro repair assay was used in an in vitro study to elucidate the effect of oxidative stress modulators on the NER capacity. Observed changes in the phenotypic repair capacity were compared with differences in gene expression of NER-related genes. Results presented in Chapter 3 clearly show that NER is at least partly controlled by redox modulation in vitro. 
These in vitro studies were subsequently followed by in vivo studies in new born piglets. In Chapter 4 it was hypothesized that oxidative stress reduces nucleotide excision repair capacities in vivo and that an antioxidant rich diet can compensate for these effects. Therefore, in this particular study, the effect of supplementing lactating mother sows with an antioxidant enriched diet on the redox modulation of NER was studied in their newborn offspring. To this end, the in vitro NER assay was adapted for the use of frozen tissues and subsequently the repair capacity in frozen pig colon tissues was assessed.

In Chapter 5, the effect of genetic and dietary factors on the DNA repair capacity in human lymphocytes was studied. Inter-individual differences by genetic polymorphisms in NER-related repair enzymes were identified and correlations with the phenotypically assessed NER capacities were studied. Moreover, the effect of a four week intervention with antioxidant-rich blue berry/apple juice on an individual's DNA repair capacity was also taken into account in these studies.

Since oxidative stress might cause a reduction in repair capacity, a certain amount of DNA lesions will not be adequately repaired prior to replication. These lesions will subsequently been handled by DNA damage tolerance mechanisms. Ubiquitination of the DNA polymerase clamp PCNA promotes the bypass of lesions and determines if this will occur via either the error-free damage avoidance pathway or the TLS pathway. The role of this ubiquitination process in the bypass and subsequent mutagenesis of BPDE-induced lesions is studied in Chapter 6.

The main findings of the studies described in this thesis are summarized and discussed in Chapter 7 . Suggestions for future research are also given. 


\section{References}

1. Rothschild B. M., Witzke B. J. and Hershkovitz I. Metastatic cancer in the Jurassic. Lancet 1999;354:398.

2. Capasso L. L. Antiquity of cancer. Int J Cancer 2005;113:2-13.

3. Shimkin M.B. Contrary to Nature Public Health Service, National Institute of Health, 1977;pp.

4. Hayes R. B. Genetic susceptibility and occupational cancer. Med Lav 1995;86:206213.

5. Luch A. Nature and nurture - lessons from chemical carcinogenesis. Nat Rev Cancer 2005;5:113-125.

6. Miller E. C. and Miller J. A. In vivo combinations between carcinogens and tissue constituents and their possible role in carcinogenesis. Cancer Res 1952;12:547556.

7. Santella R. M., Gammon M., Terry M., Senie R., Shen J., Kennedy D., Agrawal M., Faraglia B. and Zhang F. DNA adducts, DNA repair genotype/phenotype and cancer risk. Mutat Res 2005;592:29-35.

8. Bootsma $D$ et al. Nucleotide excision repair syndromes: xeroderma pigmentosum, Cockayne syndrome, and trichothiodystrophy. In: Scriver C.R., Beaudet,A.L., Sly,W.S. and Valle,D., The Metabolic and Molecular Basis of Inherited Disease, McGraw-Hill Book Co., New York, 2001, pp. 677-703.

9. Hansen E. S. International Commission for Protection Against Environmental Mutagens and Carcinogens. ICPEMC Working Paper 7/1/2. Shared risk factors for cancer and atherosclerosis--a review of the epidemiological evidence. Mutat Res 1990;239:163-179.

10. Ames B. N. Endogenous oxidative DNA damage, aging, and cancer. Free Radic Res Commun 1989;7:121-128.

11. Cooke M. S., Evans M. D., Dizdaroglu M. and Lunec J. Oxidative DNA damage: mechanisms, mutation, and disease. Faseb J 2003;17:1195-1214.

12. Oliveira P. A., Colaco A., Chaves R., Guedes-Pinto H., De-La-Cruz P. Lf and Lopes C. Chemical carcinogenesis. An Acad Bras Cienc 2007;79:593-616.

13. Biomarkers Definitions Working Group. Biomarkers and surrogate endpoints: Preferred definitions and conceptual framework. Clin. Pharmacol. Ther. 2001;69:89-95

14. Wogan G. N. Molecular epidemiology in cancer risk assessment and prevention: recent progress and avenues for future research. Environ Health Perspect 1992;98:167-178.

15. Hall M. and Grover P.L. Polycyclic aromatic hydrocarbons: metabolism, activation and tumour initiation. In: Cooper C.S. and Grover P.L., Chemical Carcinogenesis and Mutagenesis., Springer-Verlag, Berlin, 1990, pp. 327-372.

16. International Agency for Research on Cancer. Polynuclear Aromatic Compounds. Part I. Chemical, Environment and Experimental Data. IARC Monographs, 1983; Vol. 32, Lyon, France, International Agency for Research on Cancer.

17. Gelboin H. V. Benzo[alpha]pyrene metabolism, activation and carcinogenesis: role and regulation of mixed-function oxidases and related enzymes. Physiol Rev 1980;60:1107-1166.

18. Environmental Health Criteria 202. Selected Non-heterocyclic Polycyclic Aromatic Hydrocarbons. Hertel R.F. and Douben E.T. World Health Organisation. Geneva; 1998.

19. Penning T. M., Burczynski M. E., Hung C. F., McCoull K. D., Palackal N. T. and Tsuruda L. S. Dihydrodiol dehydrogenases and polycyclic aromatic hydrocarbon activation: generation of reactive and redox active o-quinones. Chem Res Toxicol 1999;12:1-18. 
20. Singh R., Sram R. J., Binkova B., Kalina I., Popov T. A., Georgieva T., Garte S., Taioli E. and Farmer P. B. The relationship between biomarkers of oxidative DNA damage, polycyclic aromatic hydrocarbon DNA adducts, antioxidant status and genetic susceptibility following exposure to environmental air pollution in humans. Mutat Res 2007;620:83-92.

21. Flowers L., Ohnishi S. T. and Penning T. M. DNA strand scission by polycyclic aromatic hydrocarbon o-quinones: role of reactive oxygen species, $\mathrm{Cu}(\mathrm{II}) / \mathrm{Cu}(\mathrm{I})$ redox cycling, and o-semiquinone anion radicals. Biochemistry 1997;36:8640-8648.

22. Cavalieri E. L. and Rogan E. G. Central role of radical cations in metabolic activation of polycyclic aromatic hydrocarbons. Xenobiotica 1995;25:677-688.

23. Rebbeck T. R. Molecular epidemiology of the human glutathione S-transferase genotypes GSTM1 and GSTT1 in cancer susceptibility. Cancer Epidemiol Biomarkers Prev 1997;6:733-743.

24. Schoket B., Papp G., Levay K., Mrackova G., Kadlubar F. F. and Vincze I. Impact of metabolic genotypes on levels of biomarkers of genotoxic exposure. Mutat Res 2001;482:57-69.

25. Lewis S. J., Cherry N. M., Niven R. M., Barber P. V. and Povey A. C. Associations between smoking, GST genotypes and N7-methylguanine levels in DNA extracted from bronchial lavage cells. Mutat Res 2004;559:11-18.

26. Palli D., Masala G., Peluso M., Gaspari L., Krogh V., Munnia A., Panico S., Saieva C., Tumino R., Vineis P. and Garte S. The effects of diet on DNA bulky adduct levels are strongly modified by GSTM1 genotype: a study on 634 subjects. Carcinogenesis 2004;25:577-584.

27. Sagher D. and Strauss B. Abasic sites from cytosine as termination signals for DNA synthesis. Nucleic Acids Res 1985;13:4285-4298.

28. Peltonen K. and Dipple A. Polycyclic aromatic hydrocarbons: chemistry of DNA adduct formation. J Occup Environ Med 1995;37:52-58.

29. Lloyd D. R., Carmichael P. L. and Phillips D. H. Comparison of the formation of 8hydroxy-2'-deoxyguanosine and single- and double-strand breaks in DNA mediated by fenton reactions. Chem Res Toxicol 1998;11:420-427.

30. Wei Q., Xu X., Cheng L., Legerski R. J. and Ali-Osman F. Simultaneous amplification of four DNA repair genes and beta-actin in human lymphocytes by multiplex reverse transcriptase-PCR. Cancer Res 1995;55:5025-5029.

31. McCoull K. D., Rindgen D., Blair I. A. and Penning T. M. Synthesis and characterization of polycyclic aromatic hydrocarbon o-quinone depurinating N7guanine adducts. Chem Res Toxicol 1999;12:237-246.

32. Kim K. B. and Lee B. M. Oxidative stress to DNA, protein, and antioxidant enzymes (superoxide dismutase and catalase) in rats treated with benzo(a)pyrene. Cancer Lett 1997;113:205-212.

33. Ohnishi S. and Kawanishi S. Double base lesions of DNA by a metabolite of carcinogenic benzo[a]pyrene. Biochem Biophys Res Commun 2002;290:778-782.

34. Douki T., Odin F., Caillat S., Favier A. and Cadet J. Predominance of the 1,N2propano 2'-deoxyguanosine adduct among 4-hydroxy-2-nonenal-induced DNA lesions. Free Radic Biol Med 2004;37:62-70.

35. Lee S. H., Oe T. and Blair I. A. 4,5-Epoxy-2(E)-decenal-induced formation of 1,N(6)-etheno-2'-deoxyadenosine and 1,N(2)-etheno-2'-deoxyguanosine adducts. Chem Res Toxicol 2002;15:300-304.

36. Rechkoblit O., Zhang Y., Guo D., Wang Z., Amin S., Krzeminsky J., Louneva N. and Geacintov N. E. trans-Lesion synthesis past bulky benzo[a]pyrene diol epoxide N2-dG and N6-dA lesions catalyzed by DNA bypass polymerases. $J$ Biol Chem 2002;277:30488-30494.

37. Zhang Y., Wu X., Guo D., Rechkoblit O., Geacintov N. E. and Wang Z. Two-step error-prone bypass of the (+)- and (-)-trans-anti-BPDE-N2-dG adducts by human DNA polymerases eta and kappa. Mutat Res 2002;510:23-35. 
38. Zhang Y., Wu X., Guo D., Rechkoblit O. and Wang Z. Activities of human DNA polymerase kappa in response to the major benzo[a]pyrene DNA adduct: error-free lesion bypass and extension synthesis from opposite the lesion. DNA Repair (Amst) 2002;1:559-569.

39. Pfeifer G. P., Denissenko M. F., Olivier M., Tretyakova N., Hecht S. S. and Hainaut P. Tobacco smoke carcinogens, DNA damage and p53 mutations in smokingassociated cancers. Oncogene 2002;21:7435-7451.

40. Le Calvez F., Mukeria A., Hunt J. D., Kelm O., Hung R. J., Taniere P., Brennan P., Boffetta P., Zaridze D. G. and Hainaut P. TP53 and KRAS mutation load and types in lung cancers in relation to tobacco smoke: distinct patterns in never, former, and current smokers. Cancer Res 2005;65:5076-5083.

41. Denissenko M. F., Pao A., Tang M. and Pfeifer G. P. Preferential formation of benzo[a]pyrene adducts at lung cancer mutational hotspots in P53. Science 1996;274:430-432.

42. Nair J., Furstenberger G., Burger F., Marks F. and Bartsch H. Promutagenic etheno-DNA adducts in multistage mouse skin carcinogenesis: correlation with lipoxygenase-catalyzed arachidonic acid metabolism. Chem Res Toxicol 2000;13:703-709.

43. Lunec J., Holloway K. A., Cooke M. S., Faux S., Griffiths H. R. and Evans M. D. Urinary 8-oxo-2'-deoxyguanosine: redox regulation of DNA repair in vivo? Free Radic Biol Med 2002;33:875-885.

44. Montesano R., Hainaut P. and Wild C. P. Hepatocellular carcinoma: from gene to public health. J Natl Cancer Inst 1997;89:1844-1851.

45. Dusinska M. and Collins A. R. The comet assay in human biomonitoring: geneenvironment interactions. Mutagenesis 2008;23:191-205.

46. Spitz M. R., Wu X., Wang Y., Wang L. E., Shete S., Amos C. I., Guo Z., Lei L., Mohrenweiser $\mathrm{H}$. and Wei $\mathrm{Q}$. Modulation of nucleotide excision repair capacity by XPD polymorphisms in lung cancer patients. Cancer Res 2001;61:1354-1357.

47. Wu X., Zhao H., Wei Q., Amos C. I., Zhang K., Guo Z., Qiao Y., Hong W. K. and Spitz M. R. XPA polymorphism associated with reduced lung cancer risk and a modulating effect on nucleotide excision repair capacity. Carcinogenesis 2003;24:505-509.

48. Friedberg E. C. DNA damage and repair. Nature 2003;421:436-440.

49. Tyson J. and Mathers J. C. Dietary and genetic modulation of DNA repair in healthy human adults. Proc Nutr Soc 2007;66:42-51.

50. Sancar A. Excision repair in mammalian cells. J Biol Chem 1995;270:15915-15918.

51. Boyer J. C., Kaufmann W. K., Brylawski B. P. and Cordeiro-Stone M. Defective postreplication repair in xeroderma pigmentosum variant fibroblasts. Cancer Res 1990;50:2593-2598.

52. Seeberg E., Eide L. and Bjoras M. The base excision repair pathway. Trends Biochem Sci 1995;20:391-397.

53. Hung R. J., Hall J., Brennan P. and Boffetta P. Genetic polymorphisms in the base excision repair pathway and cancer risk: a HuGE review. Am J Epidemiol 2005;162:925-942.

54. Radicella J. P., Dherin C., Desmaze C., Fox M. S. and Boiteux S. Cloning and characterization of hOGG1, a human homolog of the OGG1 gene of Saccharomyces cerevisiae. Proc Natl Acad Sci U S A 1997;94:8010-8015.

55. Boiteux S. and Radicella J. P. The human OGG1 gene: structure, functions, and its implication in the process of carcinogenesis. Arch Biochem Biophys 2000;377:1-8.

56. Hansen W. K. and Kelley M. R. Review of mammalian DNA repair and translational implications. J Pharmacol Exp Ther 2000;295:1-9.

57. Reardon J. T., Bessho T., Kung H. C., Bolton P. H. and Sancar A. In vitro repair of oxidative DNA damage by human nucleotide excision repair system: possible 
explanation for neurodegeneration in xeroderma pigmentosum patients. Proc Natl Acad Sci U S A 1997;94:9463-9468.

58. Dusinska M., Dzupinkova Z., Wsolova L., Harrington V. and Collins A. R. Possible involvement of XPA in repair of oxidative DNA damage deduced from analysis of damage, repair and genotype in a human population study. Mutagenesis 2006;21:205-211.

59. D'Errico M., Parlanti E., Teson M., de Jesus B. M., Degan P., Calcagnile A., Jaruga P., Bjoras M., Crescenzi M., Pedrini A. M., Egly J. M., Zambruno G., Stefanini M., Dizdaroglu M. and Dogliotti E. New functions of XPC in the protection of human skin cells from oxidative damage. Embo J 2006;25:4305-4315.

60. Friedberg E. C. How nucleotide excision repair protects against cancer. Nat Rev Cancer 2001;1:22-33.

61. Keeney S., Wein H. and Linn S. Biochemical heterogeneity in xeroderma pigmentosum complementation group E. Mutat Res 1992;273:49-56.

62. Keeney S., Chang G. J. and Linn S. Characterization of a human DNA damage binding protein implicated in xeroderma pigmentosum E. $J$ Biol Chem 1993;268:21293-21300.

63. Batty D., Rapic'-Otrin V., Levine A. S. and Wood R. D. Stable binding of human XPC complex to irradiated DNA confers strong discrimination for damaged sites. $J$ Mol Biol 2000;300:275-290.

64. Sugasawa K., Okuda Y., Saijo M., Nishi R., Matsuda N., Chu G., Mori T., Iwai S., Tanaka K., Tanaka K. and Hanaoka F. UV-induced ubiquitylation of XPC protein mediated by UV-DDB-ubiquitin ligase complex. Cell 2005;121:387-400.

65. van Hoffen A., Natarajan A. T., Mayne L. V., van Zeeland A. A., Mullenders L. H. and Venema J. Deficient repair of the transcribed strand of active genes in Cockayne's syndrome cells. Nucleic Acids Res 1993;21:5890-5895.

66. van Hoffen A., Balajee A. S., van Zeeland A. A. and Mullenders L. H. Nucleotide excision repair and its interplay with transcription. Toxicology 2003;193:79-90.

67. Sugasawa K. Xeroderma pigmentosum genes: functions inside and outside DNA repair. Carcinogenesis 2008;29:455-465.

68. Lee K. Y. and Myung K. PCNA Modifications for Regulation of Post-Replication Repair Pathways. Mol Cells 2008;26.

69. Tateishi S., Sakuraba Y., Masuyama S., Inoue H. and Yamaizumi M. Dysfunction of human Rad18 results in defective postreplication repair and hypersensitivity to multiple mutagens. Proc Natl Acad Sci U S A 2000;97:7927-7932.

70. Torres-Ramos C. A., Prakash S. and Prakash L. Requirement of RAD5 and MMS2 for postreplication repair of UV-damaged DNA in Saccharomyces cerevisiae. Mol Cell Biol 2002;22:2419-2426.

71. Wang Z. DNA damage-induced mutagenesis : a novel target for cancer prevention. Mol Interv 2001;1:269-281.

72. Hoege C., Pfander B., Moldovan G. L., Pyrowolakis G. and Jentsch S. RAD6dependent DNA repair is linked to modification of PCNA by ubiquitin and SUMO. Nature 2002;419:135-141.

73. Ulrich H. D. How to activate a damage-tolerant polymerase: consequences of PCNA modifications by ubiquitin and SUMO. Cell Cycle 2004;3:15-18.

74. Chiu R. K., Brun J., Ramaekers C., Theys J., Weng L., Lambin P., Gray D. A. and Wouters B. G. Lysine 63-polyubiquitination guards against translesion synthesisinduced mutations. PLoS Genet 2006;2:e116.

75. Xiao W., Chow B. L., Broomfield S. and Hanna M. The Saccharomyces cerevisiae RAD6 group is composed of an error-prone and two error-free postreplication repair pathways. Genetics 2000;155:1633-1641.

76. Ogi T., Shinkai Y., Tanaka K. and Ohmori H. Polkappa protects mammalian cells against the lethal and mutagenic effects of benzo[a]pyrene. Proc Natl Acad Sci U S A 2002;99:15548-15553. 
77. Johnson R. E., Washington M. T., Haracska L., Prakash S. and Prakash L. Eukaryotic polymerases iota and zeta act sequentially to bypass DNA lesions. Nature 2000;406:1015-1019.

78. Collins A. and Harrington V. Repair of oxidative DNA damage: assessing its contribution to cancer prevention. Mutagenesis 2002;17:489-493.

79. Collins A. R. and Gaivao I. DNA base excision repair as a biomarker in molecular epidemiology studies. Mol Aspects Med 2007;28:307-322.

80. Berwick $M$. and Vineis $P$. Markers of DNA repair and susceptibility to cancer in humans: an epidemiologic review. J Natl Cancer Inst 2000;92:874-897.

81. Chen J. and Stubbe J. Bleomycins: new methods will allow reinvestigation of old issues. Curr Opin Chem Biol 2004;8:175-181.

82. Lambert B., Ringborg U. and Skoog L. Age-related decrease of ultraviolet lightinduced DNA repair synthesis in human peripheral leukocytes. Cancer Res 1979;39:2792-2795.

83. Athas W. F., Hedayati M. A., Matanoski G. M., Farmer E. R. and Grossman L. Development and field-test validation of an assay for DNA repair in circulating human lymphocytes. Cancer Res 1991;51:5786-5793.

84. Qiao Y., Spitz M. R., Guo Z., Hadeyati M., Grossman L., Kraemer K. H. and Wei Q. Rapid assessment of repair of ultraviolet DNA damage with a modified host-cell reactivation assay using a luciferase reporter gene and correlation with polymorphisms of DNA repair genes in normal human lymphocytes. Mutat Res 2002;509:165-174.

85. Wei Q., Shen H., Wang L. E., Duphorne C. M., Pillow P. C., Guo Z., Qiao Y. and Spitz M. R. Association between low dietary folate intake and suboptimal cellular DNA repair capacity. Cancer Epidemiol Biomarkers Prev 2003;12:963-969.

86. Stierum R. H., van Herwijnen M. H., Maas L. M., Hageman G. J. and Kleinjans J. C. Measurement by 32P-postlabeling of (+/-)anti-benzo[a]pyrene-diolepoxide-N2deoxyguanosine adduct persistence in unstimulated human peripheral blood lymphocytes. Mutat Res 1994;325:31-37.

87. Oesch F., Aulmann W., Platt K. L. and Doerjer G. Individual differences in DNA repair capacities in man. Arch Toxicol Suppl 1987;10:172-179.

88. Celotti L., Ferraro P., Furlan D., Zanesi N. and Pavanello S. DNA repair in human lymphocytes treated in vitro with (+)-anti- and (+/-)-syn-benzo[a]pyrene diolepoxide. Mutat Res 1993;294:117-126.

89. Collins A. R., Duthie S. J., Fillion L., Gedik C. M., Vaughan N. and Wood S. G. Oxidative DNA damage in human cells: the influence of antioxidants and DNA repair. Biochem Soc Trans 1997;25:326-331.

90. Collins A. R., Duthie S. J. and Dobson V. L. Direct enzymic detection of endogenous oxidative base damage in human lymphocyte DNA. Carcinogenesis 1993;14:1733-1735.

91. Dusinská M. and Collins A. Detection of oxidised purines and UV-induced photoproducts in DNA of single cells, by inclusion of lesion-specific enzymes in the comet assay. Alternatives to Laboratory Animals 1996;24:405-411.

92. Collins A. R. The comet assay for DNA damage and repair: principles, applications, and limitations. Mol Biotechnol 2004;26:249-261.

93. Collins A. R. and Horvathova E. Oxidative DNA damage, antioxidants and DNA repair: applications of the comet assay. Biochem Soc Trans 2001;29:337-341.

94. Redaelli A., Magrassi R., Bonassi S., Abbondandolo A. and Frosina G. AP endonuclease activity in humans: development of a simple assay and analysis of ten normal individuals. Teratog Carcinog Mutagen 1998;18:17-26.

95. Elliott R. M., Astley S. B., Southon S. and Archer D. B. Measurement of cellular repair activities for oxidative DNA damage. Free Radic Biol Med 2000;28:14381446. 
96. Roldan-Arjona T., Wei Y. F., Carter K. C., Klungland A., Anselmino C., Wang R. P., Augustus $M$. and Lindahl T. Molecular cloning and functional expression of a human cDNA encoding the antimutator enzyme 8-hydroxyguanine-DNA glycosylase. Proc Natl Acad Sci U S A 1997;94:8016-8020.

97. Sauvaigo S., Guerniou V., Rapin D., Gasparutto D., Caillat S. and Favier A. An oligonucleotide microarray for the monitoring of repair enzyme activity toward different DNA base damage. Anal Biochem 2004;333:182-192.

98. Collins A. R., Dusinska M., Horvathova E., Munro E., Savio M. and Stetina R. Interindividual differences in repair of DNA base oxidation, measured in vitro with the comet assay. Mutagenesis 2001;16:297-301.

99. Tyson J., Spiers A., Caple F., Hesketh J.E. and Mathers J. C. Inter-individual variation in nucleotide excision repair capacity: potential scope for dietary modulation of DNA repair. Proceedings of the Nutrition Society 2005;64:68A

100. Food, Nutrition and the Prevention of Cancer: A Global Perspective. World Cancer Research Fund / American Institute for Cancer Research. London:WCRF UK; 1997.

101. World Cancer Research Fund / American Institute for Cancer Research. Food, Nutrition, Physical Activity, and the Prevention of Cancer: A Global Perspective. Washington DC:AIRC; 2007.

102. Bull C. and Fenech M. Genome-health nutrigenomics and nutrigenetics: nutritional requirements or 'nutriomes' for chromosomal stability and telomere maintenance at the individual level. Proc Nutr Soc 2008;67:146-156.

103. Wasson G. R., McKelvey-Martin V. J. and Downes C. S. The use of the comet assay in the study of human nutrition and cancer. Mutagenesis 2008;23:153-162.

104. Hartwig A., Asmuss M., Ehleben I., Herzer U., Kostelac D., Pelzer A., Schwerdtle T. and Burkle A. Interference by toxic metal ions with DNA repair processes and cell cycle control: molecular mechanisms. Environ Health Perspect 2002;110 Suppl 5:797-799.

105. Blessing H., Kraus S., Heindl P., Bal W. and Hartwig A. Interaction of selenium compounds with zinc finger proteins involved in DNA repair. Eur $J$ Biochem 2004;271:3190-3199.

106. Asmuss M., Mullenders L. H., Eker A. and Hartwig A. Differential effects of toxic metal compounds on the activities of Fpg and XPA, two zinc finger proteins involved in DNA repair. Carcinogenesis 2000;21:2097-2104.

107. Feinberg A. P. and Tycko B. The history of cancer epigenetics. Nat Rev Cancer 2004:4:143-153.

108. Nakagawachi T., Soejima H., Urano T., Zhao W., Higashimoto K., Satoh Y., Matsukura S., Kudo S., Kitajima Y., Harada H., Furukawa K., Matsuzaki H., Emi M., Nakabeppu Y., Miyazaki K., Sekiguchi M. and Mukai T. Silencing effect of CpG island hypermethylation and histone modifications on O6-methylguanine-DNA methyltransferase (MGMT) gene expression in human cancer. Oncogene 2003;22:8835-8844.

109. Friso S. and Choi S. W. Gene-nutrient interactions and DNA methylation. J Nutr 2002;132:2382S-2387S.

110. Galaris D. and Evangelou A. The role of oxidative stress in mechanisms of metalinduced carcinogenesis. Crit Rev Oncol Hematol 2002;42:93-103.

111. Patrick $L$. Lead toxicity part II: the role of free radical damage and the use of antioxidants in the pathology and treatment of lead toxicity. Altern Med Rev 2006;11:114-127.

112. Cebulska-Wasilewska A., Wiechec A., Panek A., Binkova B., Sram R. J. and Farmer P. B. Influence of environmental exposure to PAHs on the susceptibility of lymphocytes to DNA-damage induction and on their repair capacity. Mutat Res 2005;588:73-81. 
113. Jaiswal M., LaRusso N. F., Nishioka N., Nakabeppu Y. and Gores G. J. Human Ogg1, a protein involved in the repair of 8-oxoguanine, is inhibited by nitric oxide. Cancer Res 2001;61:6388-6393.

114. Graziewicz M., Wink D. A. and Laval F. Nitric oxide inhibits DNA ligase activity: potential mechanisms for NO-mediated DNA damage. Carcinogenesis 1996;17:2501-2505.

115. Feng Z., Hu W. and Tang M. S. Trans-4-hydroxy-2-nonenal inhibits nucleotide excision repair in human cells: a possible mechanism for lipid peroxidation-induced carcinogenesis. Proc Natl Acad Sci U S A 2004;101:8598-8602.

116. Feng Z., Hu W., Marnett L. J. and Tang M. S. Malondialdehyde, a major endogenous lipid peroxidation product, sensitizes human cells to UV- and BPDEinduced killing and mutagenesis through inhibition of nucleotide excision repair. Mutat Res 2006;601:125-136.

117. Hwang E. S. and Bowen P. E. DNA damage, a biomarker of carcinogenesis: its measurement and modulation by diet and environment. Crit Rev Food Sci Nutr 2007;47:27-50.

118. Fang Y. Z., Yang S. and Wu G. Free radicals, antioxidants, and nutrition. Nutrition 2002;18:872-879.

119. Lynn S., Yew F. H., Hwang J. W., Tseng M. J. and Jan K. Y. Glutathione can rescue the inhibitory effects of nickel on DNA ligation and repair synthesis. Carcinogenesis 1994;15:2811-2816.

120. Li Q., Gardner K., Zhang L., Tsang B., Bostick-Bruton F. and Reed E. Cisplatin induction of ERCC-1 mRNA expression in A2780/CP70 human ovarian cancer cells. J Biol Chem 1998;273:23419-23425.

121. Collins A. R., Harrington V., Drew J. and Melvin R. Nutritional modulation of DNA repair in a human intervention study. Carcinogenesis 2003;24:511-515.

122. Astley S. B., Elliott R. M., Archer D. B. and Southon S. Evidence that dietary supplementation with carotenoids and carotenoid-rich foods modulates the DNA damage: repair balance in human lymphocytes. Br J Nutr 2004;91:63-72.

123. Moller $P$. and Loft $S$. Interventions with antioxidants and nutrients in relation to oxidative DNA damage and repair. Mutat Res 2004;551:79-89.

124. Orphanides G. and Kimber I. Toxicogenetics: applications and opportunities. Toxicol Sci 2003;75:1-6.

125. Marez D., Legrand M., Sabbagh N., Guidice J. M., Spire C., Lafitte J. J., Meyer U. A. and Broly F. Polymorphism of the cytochrome P450 CYP2D6 gene in a European population: characterization of 48 mutations and 53 alleles, their frequencies and evolution. Pharmacogenetics 1997;7:193-202.

126. Iida A., Saito S., Sekine A., Harigae S., Osawa S., Mishima C., Kondo K., Kitamura Y. and Nakamura Y. Catalog of 46 single-nucleotide polymorphisms (SNPs) in the microsomal glutathione S-transferase 1 (MGST1) gene. J Hum Genet 2001;46:590594.

127. Kuehl P., Zhang J., Lin Y., Lamba J., Assem M., Schuetz J., Watkins P. B., Daly A., Wrighton S. A., Hall S. D., Maurel P., Relling M., Brimer C., Yasuda K., Venkataramanan R., Strom S., Thummel K., Boguski M. S. and Schuetz E. Sequence diversity in CYP3A promoters and characterization of the genetic basis of polymorphic CYP3A5 expression. Nat Genet 2001;27:383-391.

128. Mohrenweiser H. W., Xi T., Vazquez-Matias J. and Jones I. M. Identification of 127 amino acid substitution variants in screening 37 DNA repair genes in humans. Cancer Epidemiol Biomarkers Prev 2002;11:1054-1064.

129. Kiyohara C. and Yoshimasu K. Genetic polymorphisms in the nucleotide excision repair pathway and lung cancer risk: a meta-analysis. Int J Med Sci 2007;4:59-71.

130. Manuguerra M., Saletta F., Karagas M. R., Berwick M., Veglia F., Vineis P. and Matullo G. XRCC3 and XPD/ERCC2 single nucleotide polymorphisms and the risk of cancer: a HuGE review. Am J Epidemiol 2006;164:297-302. 
131. Kiyohara C., Takayama K. and Nakanishi Y. Association of genetic polymorphisms in the base excision repair pathway with lung cancer risk: a meta-analysis. Lung Cancer 2006;54:267-283.

132. Vogel U., Overvad K., Wallin H., Tjonneland A., Nexo B. A. and Raaschou-Nielsen O. Combinations of polymorphisms in XPD, XPC and XPA in relation to risk of lung cancer. Cancer Lett 2005;222:67-74.

133. Mateuca R., Aka P. V., De Boeck M., Hauspie R., Kirsch-Volders M. and Lison D. Influence of hOGG1, XRCC1 and XRCC3 genotypes on biomarkers of genotoxicity in workers exposed to cobalt or hard metal dusts. Toxicol Lett 2005;156:277-288.

134. Mateuca R. A., Roelants M., larmarcovai G., Aka P. V., Godderis L., Tremp A., Bonassi S., Fenech M., Berge-Lefranc J. L. and Kirsch-Volders M. hOGG1(326), XRCC1(399) and XRCC3(241) polymorphisms influence micronucleus frequencies in human lymphocytes in vivo. Mutagenesis 2008;23:35-41.

135. Cheng J., Leng S., Dai Y., Huang C., Pan Z., Niu Y., Li B. and Zheng Y. Association between nucleotide excision repair gene polymorphisms and chromosomal damage in coke-oven workers. Biomarkers 2007;12:76-86.

136. Hou S. M., Falt S., Angelini S., Yang K., Nyberg F., Lambert B. and Hemminki K. The XPD variant alleles are associated with increased aromatic DNA adduct level and lung cancer risk. Carcinogenesis 2002;23:599-603.

137. Wilms L. C., Boots A. W., de Boer V. C., Maas L. M., Pachen D. M., Gottschalk R. W., Ketelslegers H. B., Godschalk R. W., Haenen G. R., van Schooten F. J. and Kleinjans J. C. Impact of multiple genetic polymorphisms on effects of a 4-week blueberry juice intervention on ex vivo induced lymphocytic DNA damage in human volunteers. Carcinogenesis 2007;28:1800-1806.

138. van Gils C. H., Bostick R. M., Stern M. C. and Taylor J. A. Differences in base excision repair capacity may modulate the effect of dietary antioxidant intake on prostate cancer risk: an example of polymorphisms in the XRCC1 gene. Cancer Epidemiol Biomarkers Prev 2002;11:1279-1284.

139. Misra R. R., Ratnasinghe D., Tangrea J. A., Virtamo J., Andersen M. R., Barrett M., Taylor P. R. and Albanes D. Polymorphisms in the DNA repair genes XPD, XRCC1, XRCC3, and APE/ref-1, and the risk of lung cancer among male smokers in Finland. Cancer Lett 2003;191:171-178.

140. Gaivao I., Piasek A., Brevik A., Shaposhnikov S. and Collins A. R. Comet assaybased methods for measuring DNA repair in vitro; estimates of inter- and intraindividual variation. Cell Biol Toxicol 2007.

141. Hu J. J., Dubin N., Kurland D., Ma B. L. and Roush G. C. The effects of hydrogen peroxide on DNA repair activities. Mutat Res 1995;336:193-201.

142. Lunec J., Holloway K., Cooke M. and Evans M. Redox-regulation of DNA repair. Biofactors 2003;17:315-324. 



\section{Chapter 2}

\section{Development and validation of a modified comet assay to phenotypically assess nucleotide excision repair}

Based on Mutagenesis 2006;21:153-158

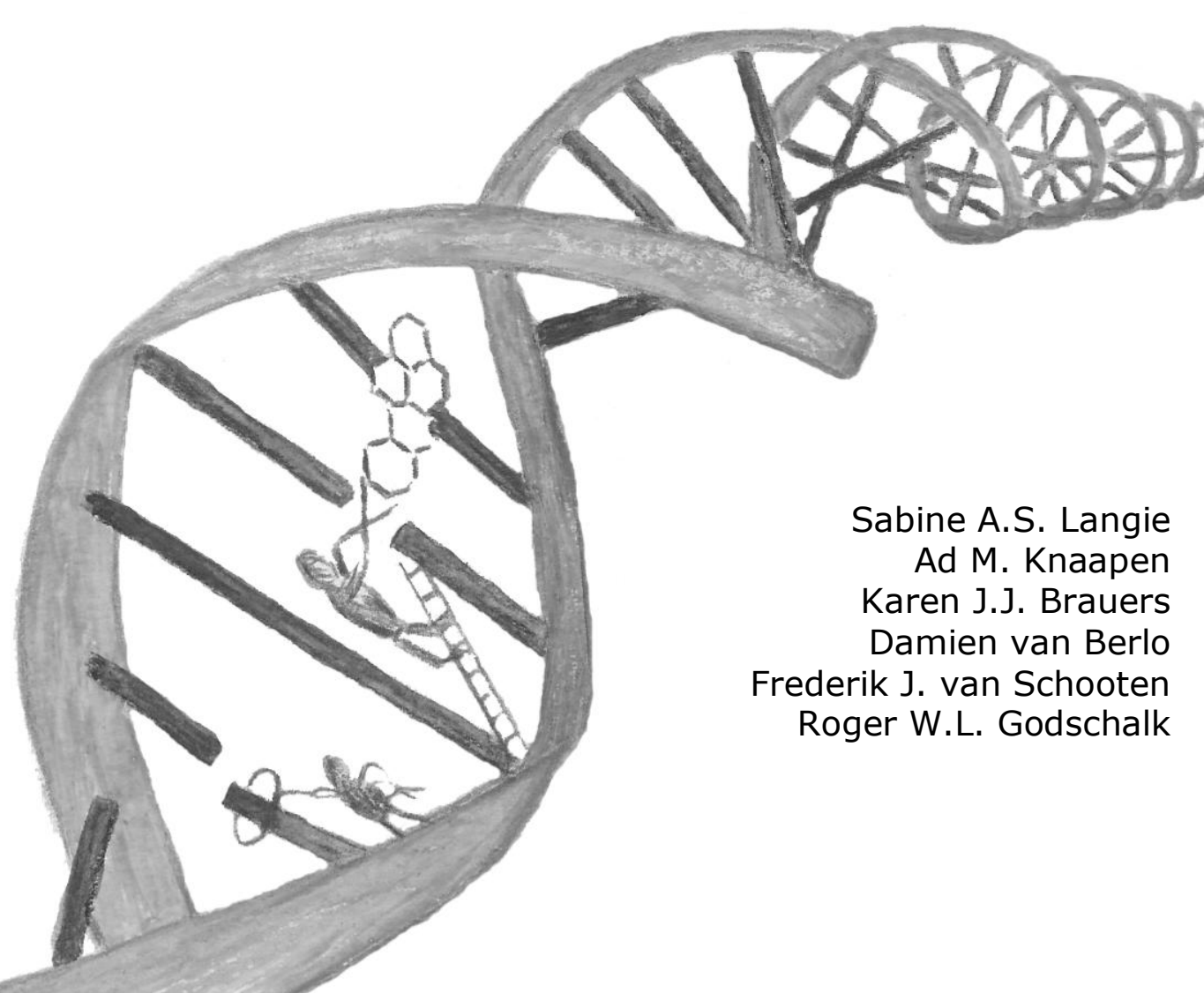




\section{Chapter 2}

\section{Abstract}

There is an increasing need for simple and reliable approaches to phenotypically assess DNA repair capacities. Therefore, a modification of the alkaline comet assay was developed to determine the ability of human lymphocyte extracts to perform the initial steps of the nucleotide excision repair (NER) process, i.e. damage recognition and incision. Gel-embedded nucleoids from A549 cells, pre-exposed to $1 \mu \mathrm{M}$ benzo[a]pyrene-diol-epoxide, were incubated with cell extracts from frozen or freshly isolated lymphocytes. The rate at which incisions are introduced and the subsequent increase in tail moment is indicative for the repair capacity of the extracts. Freshly prepared extracts from lymphocytes of human volunteers $(n=8)$ showed significant inter-individual variations in their DNA repair capacity, which correlated with the removal of bulky DNA lesions over a period of 48 hours determined by ${ }^{32} \mathrm{P}$-postlabeling $\left(\mathrm{R}^{2}=0.76, \mathrm{P}=0.005\right)$. Repeated measurements revealed a low inter-assay variation $(11 \%)$. Storage of cell extracts for more than three weeks significantly reduced (up to $80 \%$ ) the capacity to incise the damaged DNA as compared to freshly isolated extracts. This reduction was completely restored by addition of ATP to the extracts before use, as it is required for the incision step of NER. In contrast, extracts freshly prepared from frozen lymphocyte pellets can be used without loss of repair activity. DNA repair deficient XPA-/- and $X P C-/$ fibroblasts were used to further validate the assay. Although some residual capacity to incise the DNA was observed in these cells, the repair activity was restored to normal wild type levels when a complementary mixture of both extracts (thereby restoring XPA and XPC deficiency) was used. These results demonstrate that this repair assay can be applied in molecular epidemiological studies to assess inter-individual differences in NER. 


\section{Introduction}

Epidemiological studies have reported large inter-individual variations in susceptibility to environmental carcinogens and subsequent cancer risk. There is evidence that this differential susceptibility is partly due to genetically determined variations in DNA repair capacity (DRC) [1]. For instance, several studies have described the association between polymorphisms in DNA repair genes and cancer risk [2-4]. DNA repair mechanisms have evolved that protect the integrity of the genome, and these can generally be subdivided into base and nucleotide excision repair (BER and NER, respectively). Both pathways function as a result of the joint action of a variety of enzymes [5]. However, it is still not completely understood whether polymorphisms in these various DNA repair genes have a significant impact on the phenotypical activity of these repair pathways. Furthermore, by focusing on single nucleotide polymorphisms in DNA repair genes, other factors that could affect DNA repair capacities, for instance dietary modulation [6] or adaptive responses [7,8], are not taken into account. Therefore, there is an increasing need for simple and reliable approaches to phenotypically assess DRCs. Such assays should be well-characterized in terms of sensitivity, reproducibility, and both intra- and inter-individual variation.

At present, several approaches to determine DRC have been described [9-13]. In general, these assays are largely based on treatment of live cells with damaging agents and subsequent monitoring of damage removal in time. However, such assays have two major limitations: 1) they require freshly isolated cells, or cells that need to be handled in such a way that their survival after cryopreservation is assured; 2) they are timeconsuming. Furthermore, treatment of cells with relatively high levels of DNA damaging agents ex vivo could trigger a cellular response which is not present in vivo. Altogether, these limitations hamper the application of such assays in large molecular epidemiological studies.

Recently, Collins et al., developed an elegant comet assay-based method to measure phenotypical differences in BER, that was found to be applicable in molecular epidemiological studies [14]. This alternative approach involves measurement of the capacity of human lymphocyte extracts to perform the initial step of BER, i.e. damage incision, on DNA substrates carrying 8-hydroxydeoxyguanosine (8-OHdG) lesions [14]. However, up to now there are to the best of our knowledge only a few comparable comet-based assays to measure NER (e.g. [15]). Still, many human cancers are directly related to exposure to chemical carcinogens, such as polycyclic aromatic hydrocarbons $(\mathrm{PAH})$, that exert their carcinogenic action through formation of DNA adducts which are generally removed by NER. Therefore, we developed a modified comet assay, to phenotypically assess inter-individual differences in nucleotide excision repair capacities. This repair assay is based on the capacity of cell extracts to cause incisions in PAH-adduct containing DNA (specifically, benzo[a]pyrene-7,8-dihydrodiol-9,10epoxide, BPDE-DNA adducts). The assay was validated by comparison with other methodologies, such as assessment of adduct removal, as well as by using DNA repair deficient cell lines. This newly developed assay is reliable, reproducible and can be used on frozen tissues or cells, indicating its applicability in molecular epidemiological studies. 


\section{Chapter 2}

\section{Materials and methods}

\section{Principle of the assay}

Gel-embedded nucleoids from A549 cells containing high levels of BPDE-DNA adducts are incubated with cell extracts from frozen or freshly isolated lymphocytes. The principle of the assay is that NER-related enzymes that are present in cell extracts will recognize the BPDE-DNA adducts. Subsequently, the DNA is incised, causing single strand breaks that can be determined by subsequent single-cell alkaline gel electrophoresis. Damage recognition and incision are the rate limiting steps in NER [5]. Therefore, increased tail moments and percentages of fluorescence in the tail are indicative for the NER capacity of the cell extracts (see Figure 1 for an overview of the assay).

\section{Cell strains and cell culture}

A549 cells (human epithelial lung carcinoma cells) were purchased from the American Tissue Culture Collection (ATCC) and were cultured in T75 flasks in DMEM (Sigma, St. Louis) supplemented with 10\% heat inactivated fetal calf serum (FCS, Gibco Invitrogen, Scotland, UK) and 1\% penicillin/streptomycin. Cells were maintained at $37^{\circ} \mathrm{C}$ in a $5 \% \mathrm{CO}_{2}$ atmosphere.

Xeroderma pigmentosum group $\mathrm{A}$ and $\mathrm{C}$ fibroblasts (XPA-/- and XPC-/-, respectively), and normal WT-fibroblasts were obtained from the NIGMS Human Genetic Mutant Cell Respiratory (Coriell Institute for Medical Research, Camden, $\mathrm{NJ}$ ). Fibroblasts were cultured in MEM (Gibco Invitrogen, Scotland, UK) supplemented with $20 \%$ uninactivated FCS, $1 \%$ penicillin/streptomycin, $0.4 \%$ essential and non-essential amino acids, and $0.02 \%$ MEM vitamins.

\section{Preparation of BPDE exposed nucleoids from A549 cells}

One day prior to performing the repair assay, A549 cells were trypsinised at $80 \%$ confluency and diluted to a final concentration of $2 \times 10^{6} \mathrm{cells} / \mathrm{mL}$. Aliquots of $25 \mu \mathrm{l}$ of untreated A549 cells were mixed with $75 \mu$ low melting point agarose (dissolved in PBS) and transferred to microscope slides, which were pre-coated with $1.5 \%$ normal electrophoresis grade agarose (Sigma-Aldrich, Germany). Gels were covered with a cover slip and kept at $4^{\circ} \mathrm{C}$ for 45 minutes to solidify. Subsequently, cover slips were removed and slides were lysed overnight in cold $\left(4^{\circ} \mathrm{C}\right)$ lysis buffer $(2.5 \mathrm{M} \mathrm{NaCl}, 0.1$ M EDTA, $10 \mathrm{mM}$ TRIS, $0.25 \mathrm{M} \mathrm{NaOH}$, pH 10, with $10 \%$ dimethylsulfoxide and $1 \%$ Triton $X-100$ that were added just before use). The next day, slides were washed for 15 minutes with PBS. The resulting nucleoids were then exposed to BPDE $(1 \mu \mathrm{M}$ in PBS) ( $\mathrm{NCl}$ Chemical Carcinogen Reference Standard Repository, Midwest Research Institute, Kansas City, MO) or vehicle control (DMSO, 0.5\%) for 30 minutes. Finally, the slides were washed for 15 minutes in buffer B (45 mM HEPES, $0.25 \mathrm{mM}$ EDTA, $2 \%$ glycerol, $0.3 \mathrm{mg} / \mathrm{mL} \mathrm{BSA}, \mathrm{pH} 7.8$ ). 


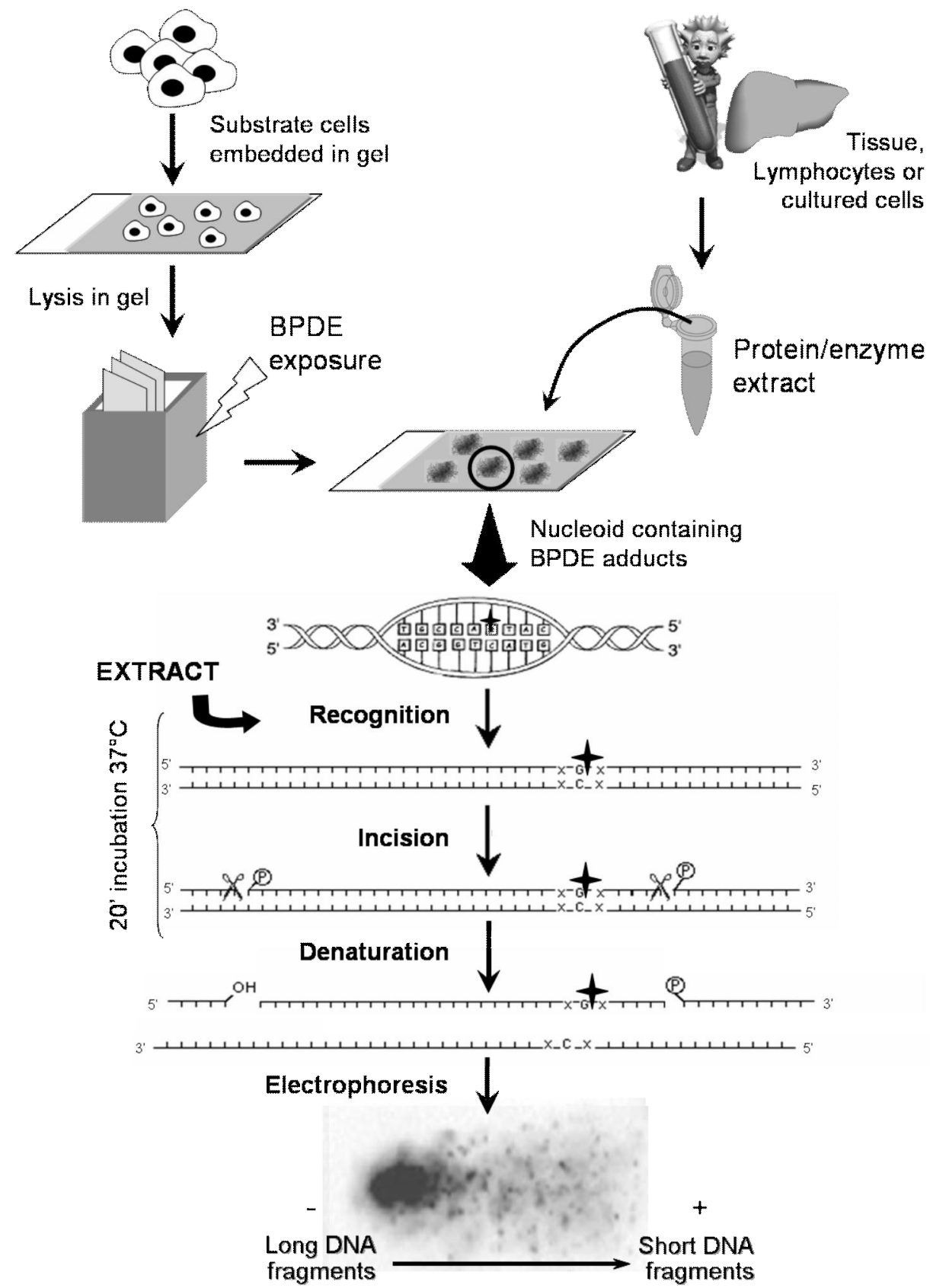

Figure 1. Schematic overview of the modified comet-based nucleotide excision repair assay. Substrate DNA consisting of gel-embedded nucleoids, which are exposed to BPDE to induce bulky-DNA adducts ( + ), are incubated with cell or tissue extracts. Standard single cell gel electrophoresis subsequently reveals the single strand breaks introduced by the NER enzymes. 


\section{Preparation of protein extracts}

The preparation of the cell extracts is based on the method developed by Redaelli et al. [16]. It is very simple and sufficient material for several assays can be obtained from lymphocytes of $10 \mathrm{~mL}$ human blood. Lymphocytes were isolated from venous blood of human volunteers using a standard density gradient centrifugation method [17]. For validation purposes, we also prepared extracts from cultured wild type (WT), XPA-/- and XPC-/- fibroblasts. Cell pellets were washed in 4x diluted extraction buffer A (45 mM HEPES, $0.4 \mathrm{M} \mathrm{KCl,} 1 \mathrm{mM}$ EDTA, $0.1 \mathrm{mM}$ dithiothreitol, $10 \%$ glycerol, adjusted to $\mathrm{pH} 7.8$ using $\mathrm{KOH}$ ), counted and diluted to a final concentration of $5 \times 10^{6}$ cells $/ \mathrm{mL}$. Then, the cell suspensions were centrifuged at $14,000 \mathrm{rpm}$ for 5 minutes and pellets were either frozen at $-20^{\circ} \mathrm{C}$ for use at a later date or immediately resuspended in $50 \mu$ buffer A per $5 \times 10^{6}$ cells. Resulting aliquots were snap frozen in liquid nitrogen. To each of these aliquots of $50 \mu \mathrm{L}, 15$ $\mu \mathrm{L}$ of $1 \%$ Triton $\mathrm{X}-100$ in buffer $\mathrm{A}$ was added, incubated for 5 minutes, and centrifuged at $11,000 \mathrm{rpm}$ for 5 minutes at $4{ }^{\circ} \mathrm{C}$ to remove cell debris. Protein concentrations were determined by the BIO-RAD DC Protein Assay Kit (Veenendaal, The Netherlands) using bovine serum albumin as a standard. Protein extracts from lymphocytes were diluted with $0.23 \%$ Triton $\mathrm{X}-100$ in buffer $\mathrm{A}$ to a concentration of $2 \mathrm{mg} / \mathrm{mL}$, whereas protein extracts from fibroblasts were diluted to $0.1 \mathrm{mg} / \mathrm{mL}$. Diluted protein extracts were then stored at $-80^{\circ} \mathrm{C}$ until use in the repair assay.

\section{Ex vivo repair incubation}

Prior to the repair assay, diluted protein extracts were thawed and 4 volumes of reaction buffer $B$ (45 mM HEPES, $0.25 \mathrm{mM}$ EDTA, 2\% glycerol, $0.3 \mathrm{mg} / \mathrm{mL}$ BSA, adjusted to $\mathrm{pH} 7.8$ with $\mathrm{KOH}$ ) were added. Extracts were kept on ice until use. To assess the ex vivo repair capacity, $50 \mu \mathrm{L}$ of the protein extract were added to each slide, containing BPDE-exposed gel-embedded nucleoids, and incubated for 10 minutes at $37^{\circ} \mathrm{C}$ on a warming plate. After the incubation, slides were immediately put on ice to stop the enzyme reactions. Subsequently, the slides were further processed according to the conventional comet assay as described previously [18]. In brief, denaturation of the DNA was performed by immersion of the slides in electrophoresis buffer $(0.3 \mathrm{M} \mathrm{NaOH}, 1 \mathrm{mM}$ EDTA, ca. $\mathrm{pH} 13)$ for 20 minutes, followed by 20 minutes of electrophoresis at $25 \mathrm{~V}$ and $300 \mathrm{~mA}$. The slides were neutralized to $\mathrm{pH} 7.4$ and subsequently dried using 100\% ethanol. Dried slides were stained with ethidium bromide $(10 \mu \mathrm{g} / \mathrm{mL})$ and comets were visualized using a Zeiss Axioskop fluorescence microscope. Samples were tested in two independent incubations within each single experiment. On every slide 50 cells were analysed randomly using the Comet assay III software program (Perceptive Instruments, Haverhill, UK). Resulting data were presented as tail moment (TM) or tail intensity (TI) \pm standard error. Tail intensity never exceeded values of $20 \%$ DNA in the tail after an incubation period of 10 minutes with the extract, indicating that the comet 
analysis is not saturated. After subtracting background levels (Figure 2, bar A) from all data, the final NER capacity was calculated using the formula:

$\mathrm{DRC}=(\mathrm{D}-\mathrm{C})-\mathrm{B}$, or: $\left(\mathrm{TM}_{\mathrm{BPDE}+/ \mathrm{Extract}}-\mathrm{TM}_{\mathrm{BPDE}-\mathrm{Ex} \text { xract }}\right)-\mathrm{TM}_{\mathrm{BPDE}+/ \mathrm{Extract}-}$

in which BPDE+/Extract+ refers to BPDE-DNA adducts containing nucleoids that were incubated with protein extract, BPDE-/Extract+ refers to non-adduct containing nucleoids that were incubated with protein extract only, and BPDE+/Extractrepresents the nucleoids exposed to BPDE only (see Figure 2, bars D, C and B, respectively).

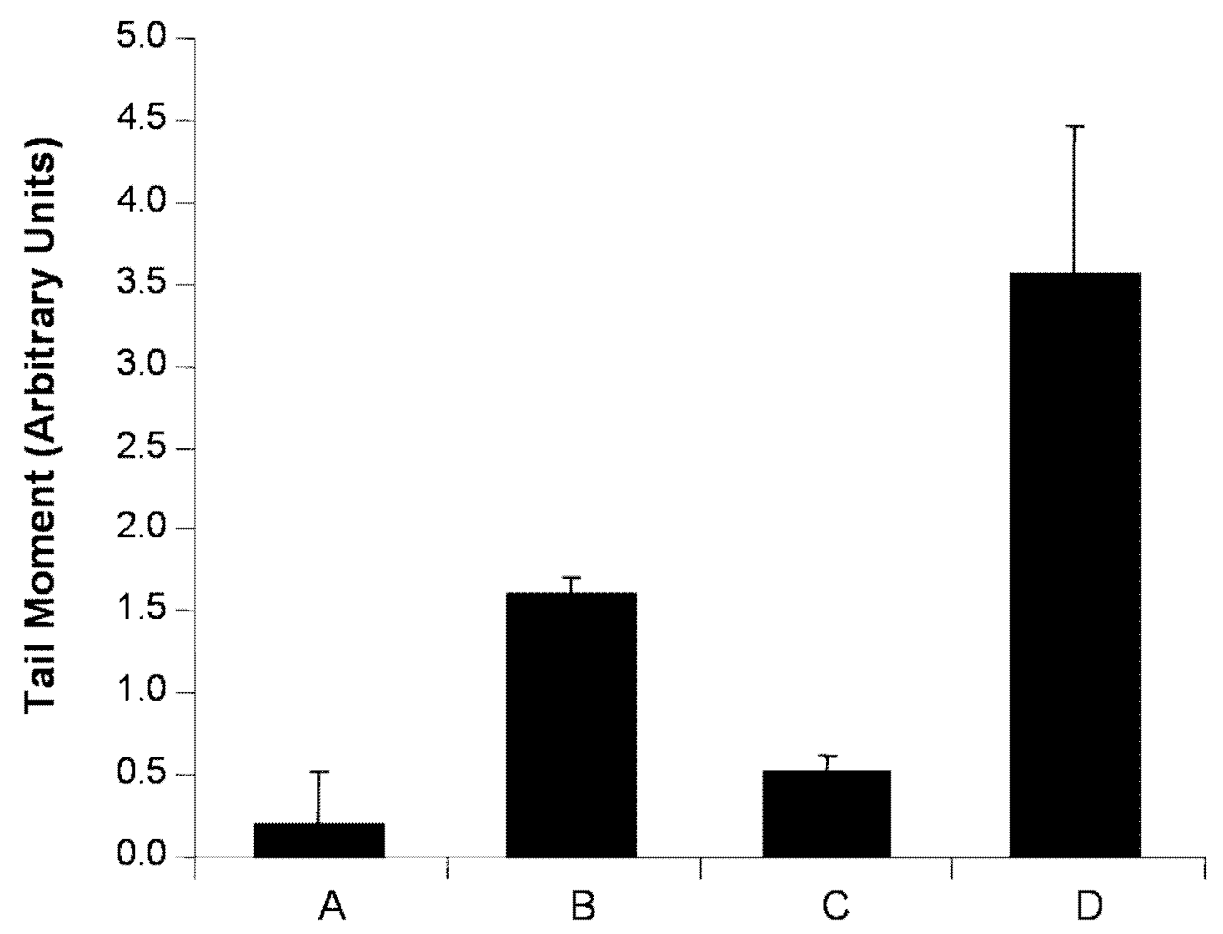

Figure 2. Principle of the assay. DNA-incising activity of human lymphocyte extracts on various nucleoids. (A) BPDE-/Extract-; nucleoids not exposed to BPDE or extract; represents background levels. (B) BPDE+/Extract-; nucleoids exposed to BPDE alone, no extract; functions as BPDE-control. (C) BPDE-/Extract+; not exposed to BPDE, only to extract, reflects recognition and incision of non-specific damage. (D) BPDE+/Extract+; BPDE pre-exposed nucleoids, incubated with extract; represents recognition and incision of total DNA damage. Data are shown as mean TM of two independent incubations within one experiment. Bars indicate standard error of mean. 


\section{DNA isolation and ${ }^{32} P$-postlabeling of BPDE-DNA adducts}

To study possible inter-individual differences in adduct removal, and to compare adduct removal with the NER capacity assessed with our modified comet assay, lymphocytes from 8 volunteers were isolated from $30 \mathrm{~mL}$ blood using gradient centrifugation [17]. After isolation, a part of these lymphocytes was used to prepare extracts to determine DRC phenotypically, another part of the lymphocytes were resuspended in RPMI, diluted to a concentration of $1 \times 10^{6}$ cells $/ \mathrm{mL}$ and exposed to $0.05 \mu \mathrm{M}$ BPDE. After 30 minutes of incubation at $37^{\circ} \mathrm{C}$, medium containing BPDE was replaced by fresh culture medium. Lymphocytes were harvested after 1, 24 and 48 hours of recovery, centrifuged at $300 \mathrm{~g}$ and pellets were stored at $-20^{\circ} \mathrm{C}$ until DNA isolation and analysis of BPDE-DNA adducts by ${ }^{32} \mathrm{P}$-postlabeling.

Standard phenol extraction was used to obtain genomic DNA. ${ }^{32} \mathrm{P}$-postlabeling was carried out using the nuclease $\mathrm{P} 1$ enrichment technique as described by Reddy and Randerath [19] with some modifications [20]. Briefly, an aliquot containing $10 \mu \mathrm{g}$ DNA was digested using micrococcal endonuclease $(0.25 \mathrm{U} / \mu \mathrm{L})$ and spleen phosphodiesterase $(2 \mu \mathrm{g} / \mu \mathrm{L})$ for 3.5 hours at $37^{\circ} \mathrm{C}$. Subsequently, DNA-digests were treated with nuclease $\mathrm{P} 1(2.5 \mu \mathrm{g} / \mu \mathrm{L})$ for 30 minutes at $37^{\circ} \mathrm{C}$. To stop the NP1reaction, $1 \mathrm{M}$ Tris $(\mathrm{pH}$ 9.6) was added. BPDE-modified nucleotides were subsequently labelled with $\left[\gamma_{-}{ }^{32} \mathrm{P}\right] \mathrm{ATP}(50 \mu \mathrm{Ci} /$ sample; ICN, Indianapolis) using T4polynucleotide kinase $(10 \mathrm{U} / \mu \mathrm{L})$ for 30 minutes at $37^{\circ} \mathrm{C}$. The radio-labelled adducted nucleotide biphosphates were separated on the PEl-cellulose sheets (Machery Nagel, Düren, Germany) by multi-directional thin layer chromatography (TLC). In all experiments two BPDE-DNA standards with known adduct levels ( 1 adduct $/ 10^{7}$ and 1 adduct $/ 10^{8}$ nucleotides) were analyzed in parallel for quantitation purposes. Quantitation was performed using Phosphor-Imaging technology (Fujifilm FLA3000).

The BPDE-DNA adduct levels were corrected for the amount of DNA in the reaction. Therefore, an aliquot of DNA-digest was diluted and labelled with $\left[\gamma_{-}{ }^{32} \mathrm{P}\right] \mathrm{ATP}$. Nucleotides were separated on a PEI-cellulose sheet by one directional TLC in $0.12 \mathrm{M} \mathrm{NaH}_{2} \mathrm{PO}_{4}(\mathrm{pH} \mathrm{6})$. A dAP-standard was analyzed along with the other samples for quantitation purposes.

\section{Validation by using NER deficient cells}

Extracts prepared from NER deficient xeroderma pigmentosum group A (XPA-/-) and group $\mathrm{C}(X P C-/-)$ fibroblasts and WT controls, were diluted with $0.23 \%$ Triton $X-$ 100 in buffer $A$ to a concentration of $0.1 \mathrm{mg} / \mathrm{mL}$ as described previously. Ex vivo repair incubations were also performed using a complementary mix of the two extracts $(1: 1, v / v)$. Hypothetically this should restore the NER capacity of the extract. In parallel pre-exposed nucleoids were also incubated with extracts form WTfibroblasts, as a control. 


\section{Results}

\section{Optimal incubation time and protein concentration}

For all the repair assay experiments, 10 minutes was chosen as the optimal incubation time for the extracts, since longer incubation periods induced higher background levels, causing a reduction of the sensitivity of the assay (TM $\mathrm{TMPE}_{\mathrm{BP}-\mathrm{Ex} \text { tract- }}$ $=0.26 \pm 0.09$ and $0.61 \pm 0.16$ for 10 and 20 minutes of incubation, respectively).

In general, the incision activity of an extract is dependent on its protein concentration. We observed that high protein concentrations caused a lower relative difference between the total (BPDE+/Extract+, bar D in Figure 2) and non-specific damage recognition (BPDE-/Extract+, bar $\mathrm{C}$ in Figure 2), thus resulting in a decreased sensitivity of the assay to detect NER capacity (Table I). Therefore, we determined the protein concentration showing the largest difference between BPDE/Extract+ and BPDE+/Extract+ values. To this end, protein extracts from lymphocytes and fibroblasts (as described above) were diluted in buffer $A$ to various concentrations ranging from 0.1 to $5 \mathrm{mg} / \mathrm{mL}$. For protein extracts prepared from human lymphocytes, the optimal protein concentration was found to be $2 \mathrm{mg} / \mathrm{mL}$ (Table I). At this protein concentration, the non-specific damage recognition resulted in a $\mathrm{TM}_{\mathrm{BPDE}-/ \text { Extract+ }}$ as low as 1.40 and a relative difference with $\mathrm{TM}_{\mathrm{BPDE}+/ \text { Extract+ }}$ of 3.00. Similar results were obtained by using $\mathrm{TI}$ as a read-out, although the relative difference between BPDE-/Extract+ and BPDE+/Extract+ values was lower.

Table I. DNA-incision activity is related to extract concentration and differs per cell type.

\begin{tabular}{|c|c|c|c|c|c|c|}
\hline \multirow{2}{*}{$\begin{array}{l}\text { Protein } \\
\text { Concentration } \\
(\mathrm{mg} / \mathrm{mL})\end{array}$} & \multicolumn{3}{|c|}{ Tail Moment (Arbitrary Units) } & \multicolumn{3}{|c|}{ Tail Intesity (\% DNA) } \\
\hline & $\begin{array}{l}\text { BPDE-/Extract+ } \\
\pm \mathrm{SE}\end{array}$ & $\begin{array}{l}\text { BPDE+/Extract+ } \\
\pm \mathrm{SE}\end{array}$ & $\begin{array}{l}\text { Relative } \\
\text { Difference }\end{array}$ & $\begin{array}{l}\text { BPDE-/Extract+ } \\
\pm \mathrm{SE}\end{array}$ & $\begin{array}{l}\text { BPDE+/Extract+ } \\
\pm \mathrm{SE}\end{array}$ & $\begin{array}{l}\text { Relative } \\
\text { Difference }\end{array}$ \\
\hline \multicolumn{7}{|l|}{ Lymphocytes } \\
\hline 5 & $6.78 \pm 0.85$ & $10.55 \pm 0.28$ & 1.56 & $23.32 \pm 2.28$ & $31.99 \pm 1.24$ & 1.37 \\
\hline 3 & $3.45 \pm 1.03$ & $6.03 \pm 0.37$ & 1.75 & $13.11 \pm 3.05$ & $19.76 \pm 1.35$ & 1.51 \\
\hline 2 & $1.40 \pm 0.29$ & $4.20 \pm 0.47$ & 3.00 & $8.22 \pm 3.23$ & $14.77 \pm 1.68$ & 1.80 \\
\hline \multicolumn{7}{|l|}{ Fibroblasts } \\
\hline 0.5 & $7.44 \pm 2.61$ & $6.25 \pm 0.06$ & 0.84 & $20.23 \pm 6.24$ & $18.03 \pm 0.17$ & 0.89 \\
\hline 0.3 & $4.25 \pm 0.06$ & $9.84 \pm 0.40$ & 2.32 & $12.30 \pm 1.09$ & $26.17 \pm 1.18$ & 2.13 \\
\hline 0.1 & $0.64 \pm 0.11$ & $4.11 \pm 0.43$ & 6.42 & $2.29 \pm 0.22$ & $12.07 \pm 1.10$ & 5.27 \\
\hline
\end{tabular}

BPDE-/Extract+ represents nucleoids exposed to extract only.

BPDE+/Extract+ represents nucleoids exposed to BPDE and extract.

$\mathrm{SE}=$ Standard error of the mean.

Protein extracts from fibroblasts showed much higher recognition and incision activity as compared to lymphocyte extracts (Table I). Protein concentrations as low as $0.5 \mathrm{mg} / \mathrm{mL}$ already resulted in $\mathrm{TM}_{\mathrm{BPDE}+/ \text { Extract+ }}$ of $6.25 \pm 0.06$. By comparison, in the case of lymphocytes, such levels of $\mathrm{TM}_{\mathrm{BPDE}+/ \text { Extract+ }}$ were only observed at $3 \mathrm{mg} / \mathrm{mL}$, suggesting that fibroblasts have a $\sim 6$-fold higher repair activity. The optimal protein concentration for fibroblasts was as low as $0.1 \mathrm{mg} / \mathrm{mL}$, showing the lowest recognition of the non-specific damage and relative differences of 6.42 and 5.27 for 


\section{Chapter 2}

$\mathrm{TM}$ and $\mathrm{TI}$, respectively. No dilutions of protein extracts lower than $2 \mathrm{mg} / \mathrm{mL}$ (for lymphocytes) or $0.1 \mathrm{mg} / \mathrm{mL}$ (for fibroblasts) were tested to prevent the TM $\mathrm{BPDE}_{\text {-/Extract+ }}$ from becoming too close to the background levels.

\section{Effect of long-term cryopreservation}

A second optimisation step was performed to evaluate the possibility to analyze frozen materials at a later date. We showed that protein extracts will lose their capacity to incise the damaged DNA after long-term storage at $-80^{\circ} \mathrm{C}$. Aliquots of the same sample thawed at intervals less than a month generated lower TM values; up to $80 \%$ reduction was observed compared to freshly isolated extracts (Figure 3 ). This reduction was completely restored by addition of $2.5 \mathrm{mM}$ ATP to the extracts before use. This is a first indication for the validity of our assay, as ATP is required for the incision step of NER [5]. In contrast, no decline in repair activity was observed after use of extracts freshly prepared from lymphocyte pellets that were stored at $-20^{\circ} \mathrm{C}$ for up to 40 days. Addition of ATP to these extracts did not further increase NER capacity.

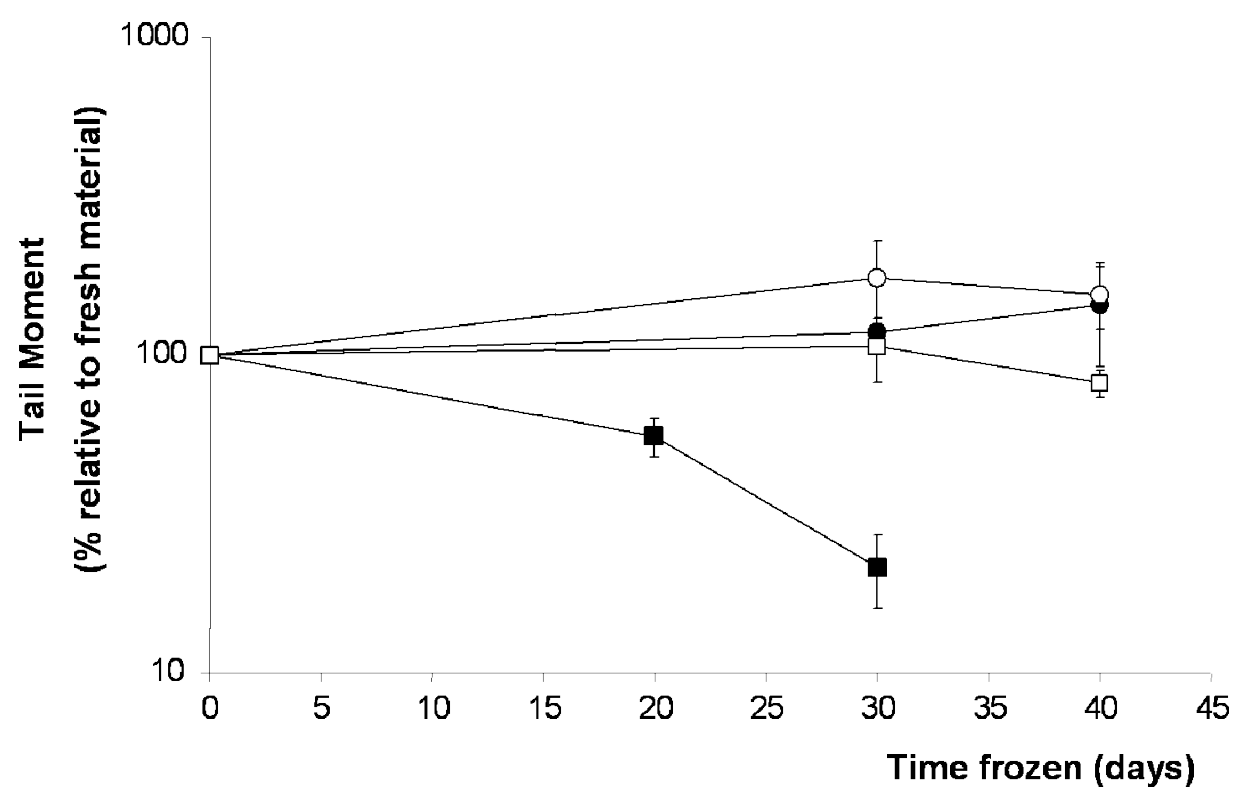

Figure 3. Effect of long-term cryopreservation on DNA-incision activity. BPDE preexposed nucleoids were incubated with; frozen extracts $(\square)$, frozen extracts to which 2.5 mM ATP was added before use $(\square)$, extracts prepared out of frozen lymphocytes $(\bullet)$, or extracts prepared out of frozen lymphocytes to which $2.5 \mathrm{mM}$ ATP was added (O). TMs of two independent experiments were calculated and data are presented as the percentage of DNA-incising activity after freezing relative to the freshly prepared extracts. Bars represent standard error of the mean. 


\section{Inter-individual variations in NER capacity and assay reproducibility}

To evaluate the reproducibility of the repair assay, lymphocytes from four volunteers were frozen as cell pellets at $-20^{\circ} \mathrm{C}$. After one month of storage, protein extracts were prepared and used in the repair assay. The results were plotted as DRCs and showed a clear variation in NER capacities between the different individuals (Figure 4). Six months later, thus after seven months of storage of the lymphocytes, the experiment was repeated to check the reproducibility of the assay. The resulting data showed the same pattern as in the first experiment and the overall variance between the two experiments was $11.1 \% \pm 4.4$.

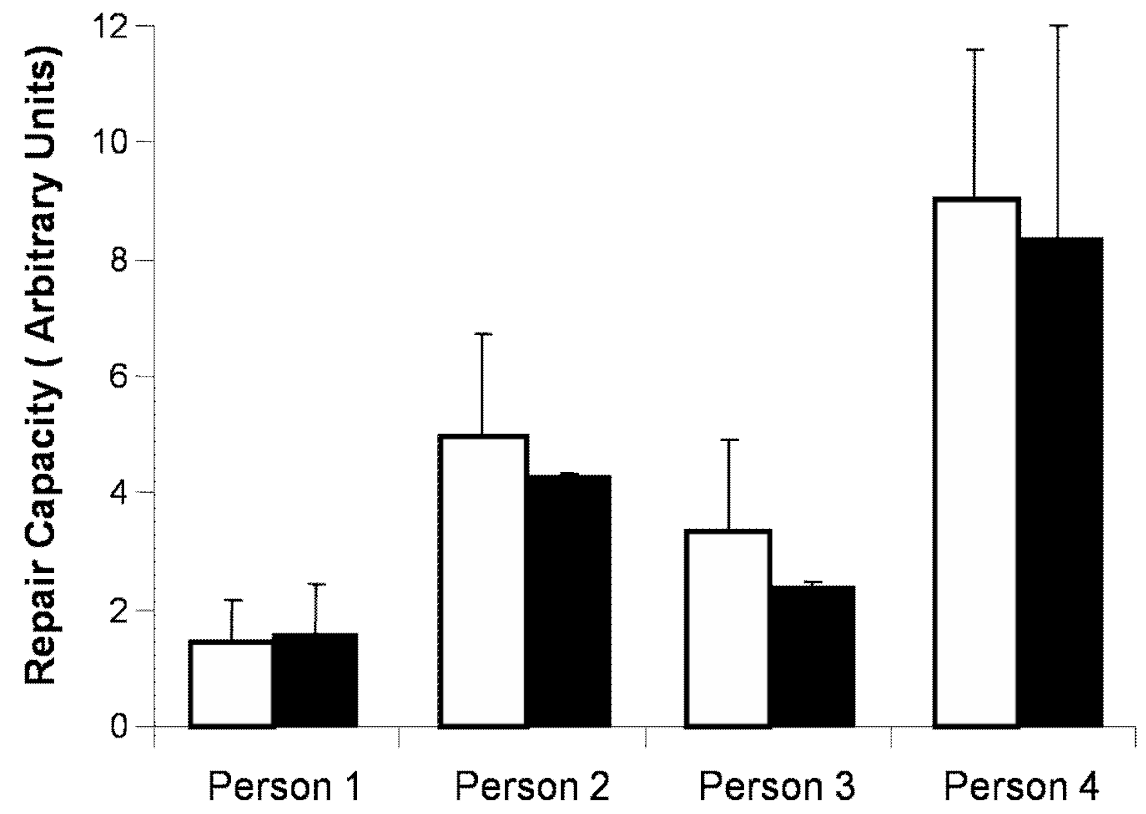

Figure 4. Reproducibility of the repair assay. Protein extracts from frozen lymphocyte pellets of four volunteers were prepared after one $(\square)$ and seven ( $\square$ ) months of storage at $-20^{\circ} \mathrm{C}$. Data are presented as the mean repair capacities $(n=2)$, calculated based on TM values. Bars indicate standard error of mean.

\section{Correlation between repair capacity and BPDE-DNA adduct removal}

As a second validation step, BPDE-DNA adduct removal as studied by ${ }^{32} \mathrm{P}$ postlabelling and NER capacity were evaluated in parallel. If the repair assay is actually measuring individual NER capacities, there should be a correlation between repair capacity as detected in our assay and BPDE-DNA adduct removal. Therefore, lymphocytes from eight volunteers were isolated. Part of it was frozen as lymphocyte pellets at $-20^{\circ} \mathrm{C}$ to assess the repair capacity by the modified comet assay. The remaining part was resuspended in RPMI and exposed to $0.05 \mu \mathrm{M}$ BPDE for 30 minutes. 


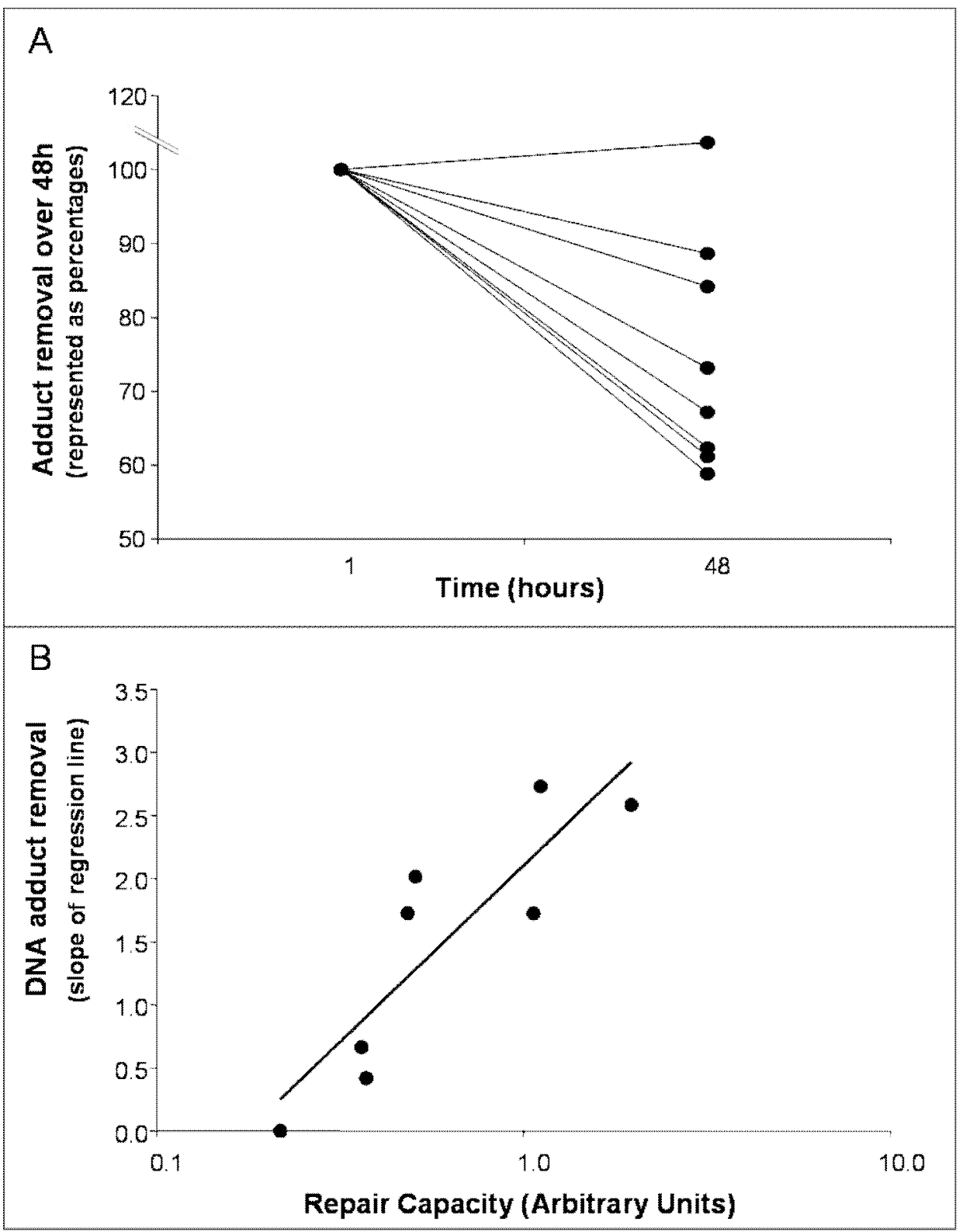

Figure 5. Correlation between repair capacity and BPDE-DNA adduct removal. Lymphocytes of eight volunteers were isolated; part was frozen as pellets and used to prepare protein extracts to perform a repair assay, the remaining part was exposed to BPDE to study DNA-adduct removal by means of ${ }^{32} \mathrm{P}$-postlabeling. (A) The results on BPDE-DNA adduct removal over 48 hours were presented as regression lines through the data points. (B) From each of these regression lines the slope, representing the decline in DNA-adduct removal over 48 hours, was plotted against the logarithm of the repair capacity $\left(\mathrm{R}^{2}=0.76, \mathrm{P}=0.005\right)$. 
After acute exposure to BPDE, DNA adduct levels were determined after 1, 24 and 48 hours of recovery. The results are presented as regression lines through the data points (Figure 5A). A significant decline of BPDE-DNA adducts in time was observed $(P=0.015)$. Subsequently, the slopes of the individual regression lines were plotted against the logarithmically transformed NER capacity, as detected by our repair assay. When the repair capacity was calculated by using tail moment values, a significant linear correlation was observed between the DRCs and BPDEadduct removing capacities $\left(R^{2}=0.76\right.$, Figure $\left.5 B\right)$. Similar results were obtained by using tail intensity as a read out of the repair capacities $\left(R^{2}=0.53, P=0.041\right)$.

\section{Repair capacity of XP-/- cells, as measured by the repair assay}

As a final validation step, the new repair assay was tested using extracts prepared from NER deficient XPA-/- and XPC-/- fibroblasts. Results were presented as percentages of the DRC of XPA-/- cell extracts (Figure 6). Each extract (XPA-/-, XPC-/-) on its own showed residual incising capacity. However, upon using a complementary mix of the two extracts (1:1), thereby reconstituting NER (both XPA and XPC enzymes are present), repair capacity was restored to the normal WT levels. This indicates that our assay indeed specifically measures NER.

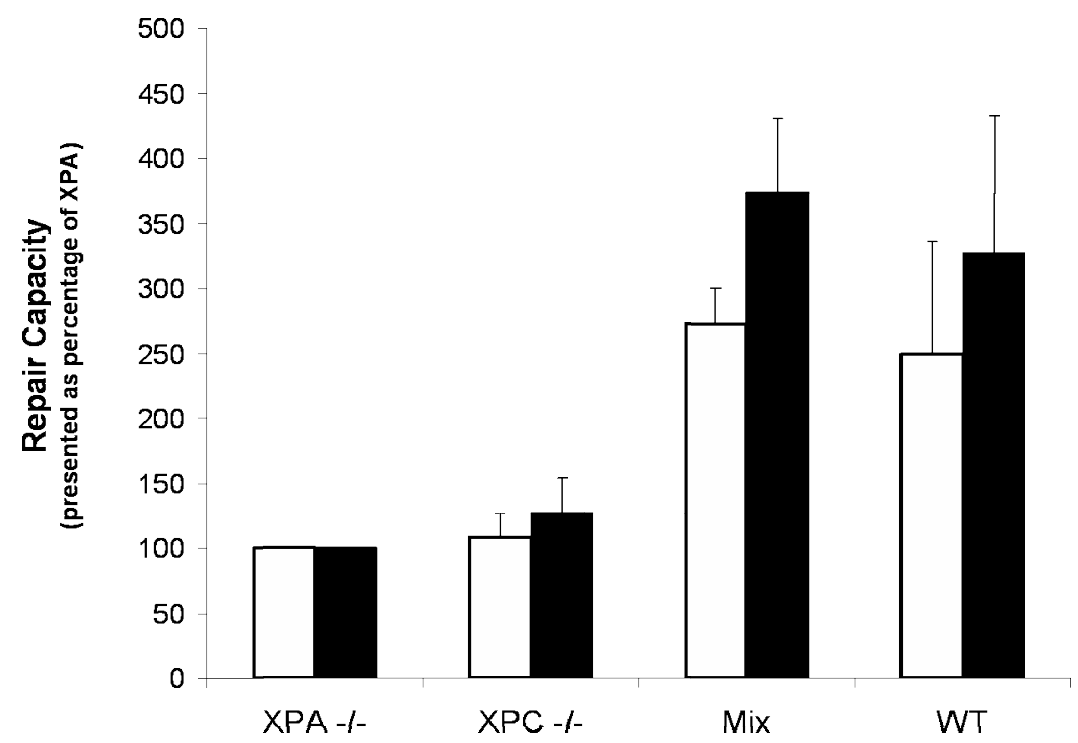

Figure 6. Repair capacity of extracts from $X P-/-$ cells. Pre- and non-exposed nucleoids were incubated with extracts from WT-fibroblasts, from XPA-/- and XPC-/- cells separately, or with a mixed extract containing 1:1 protein extract from both XP-/- cells. Mean repair capacities $(n=2)$ are presented as the percentage of the repair capacity of XPA-/- cells, calculated based on TM ( $\square)$ and TI ( $\square$ ) values. Bars indicate standard error of mean. 


\section{Chapter 2}

\section{Discussion}

During the last decades, many techniques have been developed to detect differences in DNA repair capacity [9-13]. However, a major drawback of these assays is the need to carry out prolonged incubations. Even more important is that all of these approaches require freshly isolated cell material or cells that have been stored in such a way, that they survive cryopreservation. This dramatically reduces their applicability in molecular epidemiological or intervention studies.

Recently Collins and co-workers have adapted the comet assay to measure in vitro base excision repair capacity of cell extracts [14]. We have used this as a basis to develop an assay that assesses NER. In our assay we focus on repair of bulky pre-mutagenic BPDE-DNA adducts, which are specifically repaired by NER. The method has a high sensitivity of detecting strand breaks [21], the method is quick and robust and is economical on material; only $2-3 \mathrm{~mL}$ human blood is needed to obtain sufficient material to perform one assay. Moreover, lymphocytes can be frozen as cell pellets without loss of repair activity. We think that this repair assay is highly suitable for molecular epidemiological applications and intervention studies.

Optimisation experiments showed that the DNA incising activity is dependent on the extract's protein concentration and that optimal concentrations should be assessed for each cell type (Table I). Extracts were found to lose their activity during long-term storage at $-80^{\circ} \mathrm{C}$. Addition of ATP to the extracts before use restored their repair activity completely (Figure 3 ). Interestingly, in contrast to BER, the incision step of NER is ATP dependent. These results are a first indication that the predominant activity measured by this assay is the incising activity of NERenzymes. A further validation was provided by the close correlation between the removal of BPDE-DNA adducts, specifically involving NER, and the corresponding DRC of lymphocytes from eight individuals (Figure 5B).

To further confirm our findings, the repair assay was also performed using extracts from XPA-/- and XPC-/- fibroblasts (Figure 6). Although it is generally accepted that XPA is essential for the recognition and incision of damaged DNA by the NER pathway, the extracts from XPA deficient fibroblasts showed some residual capacity to incise the BPDE-treated DNA in our assay. It is not yet known whether these incisions are made by NER-related enzymes in absence of XPA, or by other pathways that recognize BPDE-damaged sites [22]. Nonetheless, the capacity to recognise and incise BPDE-DNA adducts is reduced in extracts of XPC and XPA deficient cells, whereas it is restored by using a mixture of both extracts, indicating the validity of our assay.

In conclusion, we developed and validated an assay to phenotypically assess NER. Our assay is able to assess inter-individual differences in DRC and has a high reproducibility. Moreover, the assay is versatile, as it can be readily adapted to measure excision capacities of extracts of human cells or tissues on nucleoids containing lesions other than BPDE-DNA adducts, e.g. substrates exposed to UV, $X$-rays or MMS [23]. The technique could still be fine-tuned by using nuclear cell 
extracts to improve the sensitivity even further [23], but this would decrease its applicability in field studies, as it is more time consuming. On the other hand, many tissue banks have stored human samples as total white blood cells (WBC) rather than lymphocytes. Theoretically, it is possible to use protein extracts from total WBC to assess inter-individual differences in DNA repair. However, differences between WBC-subpopulations (e.g. lymphocytes, granulocytes and monocytes) need to be assessed first to correctly interpret the results obtained from total WBC extracts. Finally, this modified comet assay provides a powerful tool to further substantiate the role of DNA repair capacity in the development of cancer and to provide answers to important research questions on DNA repair and human health.

\section{Acknowledgments}

We are thankful to Dr. Andrew R. Collins (Department of Nutrition, University of Oslo, Oslo, Norway) for providing us with the protocol on the base excision in vitro repair assay. A.M. Knaapen was supported by a postdoctoral fellowship from the Netherlands Organisation for Scientific Research (NWO, grant 916.46.092) 


\section{References}

1. Wei Q. and Spitz M. R. The role of DNA repair capacity in susceptibility to lung cancer: a review. Cancer Metastasis Rev 1997;16:295-307.

2. Andrew A. S., Nelson H. H., Kelsey K. T., Moore J. H., Meng A. C., Casella D. P., Tosteson T. D., Schned A. R. and Karagas M. R. Concordance of multiple analytical approaches demonstrates a complex relationship between DNA repair gene SNPs, smoking and bladder cancer susceptibility. Carcinogenesis 2006;27:1030-1037.

3. Lovatt T., Alldersea J., Lear J. T., Hoban P. R., Ramachandran S., Fryer A. A., Smith A. G. and Strange R. C. Polymorphism in the nuclear excision repair gene ERCC2/XPD: association between an exon 6-exon 10 haplotype and susceptibility to cutaneous basal cell carcinoma. Hum Mutat 2005;25:353-359.

4. Matullo G., Peluso M., Polidoro S., Guarrera S., Munnia A., Krogh V., Masala G., Berrino F., Panico S., Tumino R., Vineis P. and Palli D. Combination of DNA repair gene single nucleotide polymorphisms and increased levels of DNA adducts in a population-based study. Cancer Epidemiol Biomarkers Prev 2003;12:674-677.

5. Hansen W. K. and Kelley M. R. Review of mammalian DNA repair and translational implications. J Pharmacol Exp Ther 2000;295:1-9.

6. Collins A. R., Harrington V., Drew J. and Melvin R. Nutritional modulation of DNA repair in a human intervention study. Carcinogenesis 2003;24:511-515.

7. Miura Y. Oxidative stress, radiation-adaptive responses, and aging. J Radiat Res (Tokyo) 2004;45:357-372.

8. $\quad$ Cramers P., Atanasova P., Vrolijk H., Darroudi F., van Zeeland A. A., Huiskamp R., Mullenders L. H. and Kleinjans J. C. Pre-exposure to low doses: modulation of $X-$ ray-induced dna damage and repair? Radiat Res 2005;164:383-390.

9. Berwick $M$. and Vineis P. Markers of DNA repair and susceptibility to cancer in humans: an epidemiologic review. J Natl Cancer Inst 2000;92:874-897.

10. Wei Q., Cheng L., Amos C. I., Wang L. E., Guo Z., Hong W. K. and Spitz M. R. Repair of tobacco carcinogen-induced DNA adducts and lung cancer risk: a molecular epidemiologic study. J Natl Cancer Inst 2000;92:1764-1772.

11. Wei Q., Matanoski G. M., Farmer E. R., Hedayati M. A. and Grossman L. DNA repair and aging in basal cell carcinoma: a molecular epidemiology study. Proc Natl Acad Sci U S A 1993;90:1614-1618.

12. Collins A. R. The comet assay for DNA damage and repair: principles, applications, and limitations. Mol Biotechnol 2004;26:249-261.

13. Kennedy D. O., Agrawal M., Shen J., Terry M. B., Zhang F. F., Senie R. T., Motykiewicz G. and Santella R. M. DNA repair capacity of lymphoblastoid cell lines from sisters discordant for breast cancer. J Natl Cancer Inst 2005;97:127-132.

14. Collins A. R., Dusinska M., Horvathova E., Munro E., Savio M. and Stetina R. Interindividual differences in repair of DNA base oxidation, measured in vitro with the comet assay. Mutagenesis 2001;16:297-301.

15. Collins A. R., Fleming I. M. and Gedik C. M. In vitro repair of oxidative and ultraviolet-induced DNA damage in supercoiled nucleoid DNA by human cell extract. Biochim Biophys Acta 1994;1219:724-727.

16. Redaelli A., Magrassi R., Bonassi S., Abbondandolo A. and Frosina G. AP endonuclease activity in humans: development of a simple assay and analysis of ten normal individuals. Teratog Carcinog Mutagen 1998;18:17-26.

17. Boyum A. Isolation of lymphocytes, granulocytes and macrophages. Scand $J$ Immunol 1976; Suppl 5:9-15.

18. Knaapen A. M., Schins R. P., Borm P. J. and van Schooten F. J. Nitrite enhances neutrophil-induced DNA strand breakage in pulmonary epithelial cells by inhibition of myeloperoxidase. Carcinogenesis 2005;26:1642-1648. 
19. Reddy M. V. and Randerath K. Nuclease P1-mediated enhancement of sensitivity of 32P-postlabeling test for structurally diverse DNA adducts. Carcinogenesis 1986;7:1543-1551.

20. Godschalk R. W., Maas L. M., Van Zandwijk N., van 't Veer L. J., Breedijk A., Borm P. J., Verhaert J., Kleinjans J. C. and van Schooten F. J. Differences in aromaticDNA adduct levels between alveolar macrophages and subpopulations of white blood cells from smokers. Carcinogenesis 1998;19:819-825.

21. Collins A. R., Dusinska M., Gedik C. M. and Stetina R. Oxidative damage to DNA: do we have a reliable biomarker? Environ Health Perspect 1996;104 Suppl 3:465469.

22. Evans E., Moggs J. G., Hwang J. R., Egly J. M. and Wood R. D. Mechanism of open complex and dual incision formation by human nucleotide excision repair factors. Embo J 1997;16:6559-6573.

23. Wang A. S., Ramanathan B., Chien Y. H., Goparaju C. M. and Jan K. Y. Comet assay with nuclear extract incubation. Anal Biochem 2005;337:70-75. 



\section{Q 3 \\ Chapter 3}

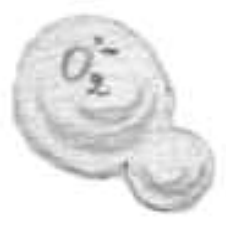

\section{The role of glutathione in the regulation of nucleotide excision repair during oxidative stress}

Published in Toxicology Letters 2007;168:302-309

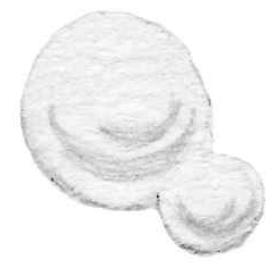

Sabine A.S. Langie Ad M. Knaapen Joyce M.J. Houben Frederik C. van Kempen Joep P.J. de Hoon Ralph W.H. Gottschalk Roger W.L. Godschalk Frederik J. van Schooten 


\section{Chapter 3}

\section{Abstract}

Nucleotide excision repair (NER) mainly repairs bulky DNA adducts and helix distorting lesions, but is additionally considered to be a back-up system for base excision repair to remove oxidative stress induced DNA damage. Therefore, it can be speculated that NER is up-regulated or primed by oxidative stress. Exposure of human pulmonary epithelial cells (A549) to non-toxic doses of $100 \mu \mathrm{M} \mathrm{H}_{2} \mathrm{O}_{2}$ indeed showed a 2 to 4.5-fold increase in expression of XPA, XPC, ERCC4 and ERCC5, whereas the expression of ERCC1 was 5-fold decreased. Phenotypical assessment of NER capacity (i.e. recognition and incision of benzo[a]pyrene-DNA adducts) showed a significant decrease to less than $50 \%$ after $\mathrm{H}_{2} \mathrm{O}_{2}$ exposure, which paralleled the effects of $\mathrm{H}_{2} \mathrm{O}_{2}$ on ERCC1 expression. To study the possible involvement of glutathione $(\mathrm{GSH})$ in the regulation of NER, cells were pre-incubated with $0.5 \mathrm{mM}$ $\mathrm{BSO}$, resulting in total GSH depletion and increased intracellular oxidative stress. In GSH-depleted cells, the down-regulation of ERCC1 expression by $\mathrm{H}_{2} \mathrm{O}_{2}$ was completely abolished and the up-regulation of ERCC4 expression was potentiated from 2.5-fold to >10-fold. Similarly, the $\mathrm{H}_{2} \mathrm{O}_{2}$ induced decrease in NER capacity was absent in GSH-depleted cells. Overall, our data suggest that NER capacity as well as the expression of NER related genes can be modulated by oxidative stress. ERCC1 expression and NER capacity correlated strongly $\left(R^{2}=0.85, P<0.01\right)$ after oxidant exposure, indicating ERCC1 as a specific target for oxidative stress induced modification of NER. 


\section{Introduction}

Exposure of cells to endogenously or exogenously formed reactive oxygen species (ROS) may cause damage to a variety of molecular targets, including DNA. If these oxidative DNA lesions are not removed by DNA repair mechanisms in time, they can become self-perpetuating mutations that contribute to ageing and human degenerative diseases such as cancer [1-3]. The major pathway for the repair of ROS induced DNA base damages is considered to be the base-excision repair (BER) pathway $[4,5]$. However, recent studies have identified proteins belonging to other repair pathways to be involved in the removal of oxidative DNA lesions, either acting as back-up repair systems or as cofactors to improve the efficiency of BER [6-8]. Especially the nucleotide excision repair (NER) pathway is considered to be an important back-up system in cases where massive oxidative stress causes high levels of oxidative DNA damage. For instance, there appears to be a synergism between BER and NER in yeast [9], and Reardon et al. [10] demonstrated the removal of 8-oxodG by NER. Furthermore, D'Errico and co-workers recently showed that the NER related enzyme XPC plays an unexpected role in the cellular protection against oxidative DNA damage, most likely by acting as a co-factor in BER [7]. Another NER protein, XPG, was found to be involved in the initiation of BER via the DNA glycosylase hNTH1 [11]. Finally, Dušinská et al [12] revealed that also XPA might be involved in the repair of oxidized bases. Based on these observations it is conceivable that regulation of NER is at least partly controlled by oxidative stress mediators. Indeed, several genes that encode for NER proteins have binding sequences in their promoter regions that can be recognized by redoxsensitive transcription factors. For instance, the expression of ERCC1, which functions as a 5 'endonuclease in NER, can be mediated by the redox-sensitive transcription factor AP-1 $[13,14]$.

The aim of the present study was to obtain further insight in the relation between oxidative stress and nucleotide excision repair. To this end, A549 lung epithelial cells were exposed to non-cytotoxic doses of hydrogen peroxide $\left(\mathrm{H}_{2} \mathrm{O}_{2}\right)$ to modulate the cellular redox-status, which was expected to result in an up-regulation of NER related genes and increased NER capacity. As an additional tool to modify intracellular oxidative stress, we used D,L-buthione-S,R-sulfoximine (BSO) to deplete cellular glutathione (GSH). We assessed the expression of various NER related genes, including XPA, XPC, ERCC1, ERCC4 (a.k.a. XPF), and ERCC5 (a.k.a. $X P G$ ) by quantitative RT-PCR. To study the effect of oxidative stress on actual NER capacity, a modified comet assay was applied [15]. A strong correlation $\left(R^{2}=0.85, P<0.01\right)$ was observed between $E R C C 1$ expression and the capacity of NER to recognize and incise bulky DNA adducts under oxidative stress conditions. These data suggest a crucial role of ERCC1 in redox status-modified NER capacity. 


\section{Chapter 3}

\section{Materials and Methods}

\section{Chemicals}

Dulbecco's Modified Eagles Medium (DMEM), Tris, KAc, alkaline phosphatase, BSO, (low melting point) agarose, TritonX-100, glycerol and BSA were obtained from Sigma (St. Louis, USA). Fetal Calf Serum (FCS), trypsin, TRIzol, Hanks Balanced Salt Solution (HBSS; with and without Ca/Mg), Penicillin/streptomycin and ethidium bromide were purchased from Gibco Invitrogen (Scotland, UK). Benzo[a]pyrene-7,8-dihydrodiol-9,10-epoxide (BPDE) was obtained from $\mathrm{NCl}$ Chemical Carcinogen Reference Standard Repository (Midwest Research Institute, Kansas City). Dimethyl sulfoxide (DMSO), EDTA, DTT, SDS, $\mathrm{H}_{2} \mathrm{O}_{2}, \mathrm{KOH}, \mathrm{KCL}$, $\mathrm{NaOH}, \mathrm{NaCl}$, chloroform, iso-propanol, ethanol and mercapto-ethanol were obtained from Merck (Germany). Proteinase K and RNase were supplied by Roche (New York, USA). Dihydrorhodamine-123 (DHR) was obtained from Invitrogen (Breda, The Netherlands) and HEPES from MP Biomedicals (Eschwege, Germany).

\section{Cell culture and exposure}

A549 cells (human epithelial lung carcinoma cells) were purchased from the American Tissue Culture Collection (ATCC) and were cultured in T75 flasks in DMEM supplemented with $10 \%$ heat inactivated FCS and $1 \%$ penicillin/streptomycin. Cells were maintained at $37^{\circ} \mathrm{C}$ in a $5 \% \mathrm{CO}_{2}$ atmosphere. All experiments were performed at approximately $80 \%$ confluency.

To study the effect of oxidative stress on NER, cells were exposed to $\mathrm{H}_{2} \mathrm{O}_{2}$ with or without prior exposure to BSO. Cells were exposed to $500 \mu \mathrm{M} B S O$ dissolved in culture medium for 24 hours to deplete GSH. At this concentration of BSO, GSH levels were decreased to less than $1 \%$ of the control level (data not shown). For $\mathrm{H}_{2} \mathrm{O}_{2}$ treatment, HBSS with $\mathrm{Ca}$ and $\mathrm{Mg}\left(\mathrm{HBSS}^{+/+}\right)$was used as a vehicle instead of culture medium. For gene expression and DNA repair capacity studies, cells were harvested at various time-periods following $\mathrm{H}_{2} \mathrm{O}_{2}$ exposure, with or without prior treatment with BSO.

\section{Measurement of cytotoxicity}

Cytotoxicity of $\mathrm{H}_{2} \mathrm{O}_{2}$ and $\mathrm{BSO}$ was evaluated using the MTT-colorimetric assay according to Mosmann [16], as described previously [17]. The test is based on the reduction of soluble yellow 3-(4, 5-dimethylthiazol-2-yl)-2,5-diphenyl-tetrazolium (MTT) salt to blue soluble formazan by mitochondrial succinate dehydrogenase. Briefly, cells were seeded in 96-well plates. At confluency, cells were exposed to various concentrations of $\mathrm{H}_{2} \mathrm{O}_{2}\left(0-1000 \mu \mathrm{M}\right.$ in $\left.\mathrm{HBSS}^{+/+}\right)$for 2 hours, with or without 24 hours of pre-exposure to $500 \mu \mathrm{M}$ of BSO. After incubation with $\mathrm{H}_{2} \mathrm{O}_{2}, 25 \mu \mathrm{L}$ of MTT (1 mg/mL) dissolved in PBS, was added and cells were incubated for another 3 hours. Finally, solutions were removed, formazan crystals were dissolved in DMSO 
$(200 \mu \mathrm{L})$ and absorption was measured using a microplate reader at $540 \mathrm{~nm}$. Absorbance was expressed as percentage of control, reflecting viability of the cells.

\section{Measurement of intracellular oxidative stress}

To determine intracellular oxidative stress, oxidation of dihydrorhodamine 123 (DHR) to rhodamine was measured using flow cytometry, as described by Henderson and Chappell [18] with some modifications. Briefly, A549 cells were seeded in 24-well plates at a concentration of $1.25 \times 10^{5}$ cells in $500 \mu \mathrm{L}$ culture medium. The next day, the cells were loaded with DHR at a final concentration of 10 $\mu \mathrm{M}$ for 30 minutes at $37^{\circ} \mathrm{C}$, and subsequently exposed to $100 \mu \mathrm{M} \mathrm{H}_{2} \mathrm{O}_{2}$ for 1 hour with or without prior incubation with $500 \mu \mathrm{M}$ BSO for 24 hours. After incubation, medium was poured off, cells were detached with trypsin and collected in tubes with $2 \mathrm{~mL}$ culture medium, followed by centrifugation at $11,000 \mathrm{rpm}$ at $4^{\circ} \mathrm{C}$ for 5 minutes. Supernatant was removed and the cells were resuspended in ice-cold $0.5 \%$ BSAPBS at a concentration of $5 \times 10^{5}$ cells $/ \mathrm{mL}$. Rhodamine fluorescence was measured at $530 \mathrm{~nm}$ using FACS. Mean intracellular rhodamine fluorescence intensities were used for data analysis.

\section{Gene expression analysis by real-time PCR}

For the gene expression studies, cells were washed with $\mathrm{HBSS}^{-/-}$and subsequently exposed to $100 \mu \mathrm{M} \mathrm{H}_{2} \mathrm{O}_{2}$ dissolved in $\mathrm{HBSS}^{+/+}$at $37^{\circ} \mathrm{C}, 5 \% \mathrm{CO}_{2}$ for 15 minutes. In parallel, control cells were incubated with $\mathrm{HBSS}^{+/+}$only. After incubation, cells were washed and normal culture medium was added to all cells to allow for recovery for 2, 4, 8 or 24 hours. For $\mathrm{t}=0$ hours, cells were washed and TRIzol was added immediately. This was repeated for the other samples at the various recovery periods. To study the role of GSH depletion on gene expression of NER-related genes, A549 cells were incubated with BSO containing medium (as described) at $37^{\circ} \mathrm{C}, 5 \% \mathrm{CO}_{2}$ for 24 hours, resulting in total $\mathrm{GSH}$-depletion. A $24 \mathrm{~h}$-control sample was included and incubated with culture medium only. After incubation with BSO, medium was removed and TRIzol was added. In another set of experiments cells were pre-exposed to $500 \mu \mathrm{M}$ BSO for 24 hours to ensure total GSH depletion and subsequently treated with $\mathrm{H}_{2} \mathrm{O}_{2}$ for 15 minutes, followed by recovery for the time points indicated above. All experiments were at least performed in duplicate. Each sample was lysed in $1 \mathrm{~mL}$ TRIzol and stored at $-20^{\circ} \mathrm{C}$ until use for RNA isolation.

Total RNA was isolated from Trizol according to the manufacturer's protocol. Isolated RNA was purified using the RNeasy® Mini Kit (Qiagen) together with DNAse treatment (RNAse-free DNAse provided by Qiagen) according to the manufacturer's recommendations. Quantity and purity of the RNA was determined spectrophotometrically. cDNA was prepared using the iScript ${ }^{\mathrm{TM}}$ CDNA Synthesis kit (BioRad, CA, USA), starting with $1 \mu \mathrm{g}$ of RNA. CDNA was 15x diluted in water before use in the rtPCR reaction. Real-time $P C R$ reactions were performed using a BioRad MyiQ iCycler Single Color RT-PCR detection system using $i^{T M}$ SYBR® 


\section{Chapter 3}

Green Supermix, containing iTaq Polymerase, dNTPs, SYBRGreen I and buffers (BioRad). Reactions were initiated by incubating the samples at $95{ }^{\circ} \mathrm{C}$ for 3 minutes to activate Taq polymerase, followed by 40 cycles of 15 seconds at $95{ }^{\circ} \mathrm{C}$ and 45 seconds at $60^{\circ} \mathrm{C}$. Melting curve analysis was performed starting at $60{ }^{\circ} \mathrm{C}$ with stepwise temperature elevations of $0.5^{\circ} \mathrm{C}$ every 10 seconds to check for nonspecific products. Three constitutively expressed genes were included as reference; betaactin, $\beta$-microglobulin and cyclophilin A.

RT-PCR primers were designed using Primer express software (Applied Biosystems; $A B I 2.0)$ and sequences were as follows:

XPA: 5'-CCG ACA GGA AAA CCG AGA AA-3' (forward) and 5'-TTC CAC ACG CTG CTT CTT ACT G-3' (reverse),

XPC: 5'-CCC AGC CCG CTT TAC CA-3' (forward) and 5'-TGC ATT AAC TGT AAA TGT TCC AAT GA-3' (reverse),

ERCC1: 5'-GGG AAT TTG GCG ACG TAA TTC-3' (forward) and 5'-ACC CCT CGA CGA GGA TGA G-3' (reverse),

ERCC4: 5'-CAC CTC CCT CGC CGT GTA-3' (forward) and 5'-CGC AAA TAT AAC ACC ACC TTG-3' (reverse),

ERCC5: 5'-GCA TGA AAT CTT GAC TGA TAT GAA AGA-3' (forward) and 5'-TAA GCA AGC CTT TGA GTT GGT ACT G-3' (reverse),

$\beta$-actin: 5'-CCT GGC ACC CAG CAC AAT-3' (forward) and 5'-GCC GAT CCA CAC GGA GTA CT-3' (reverse),

$\beta$-2 microglobulin: 5'-TGA CTT TGT CAC AGC CCA AGA TA-3' (forward) and 5'AAT GCG GCA TCT TCA AAC CT-3' (reverse)

cyclophilin A: 5'-TTC CTG CTT TCA CAG AAT TAT TCC-3' (forward) and 5'-GCC ACC AGT GCC ATT ATG G-3' (reverse).

PCR efficiency of all primer sets, as assessed by the use of cDNA dilution curves, was approximately $100 \%$. Data were analyzed using the MyiQ Software system (BioRad) and were expressed as relative gene expression (fold increase) using the $\Delta \Delta \mathrm{Ct}$ method [19]. The mean $\mathrm{Ct}$ value of the three house-keeping genes was calculated for all samples and used as reference Ct. For each gene, the average fold change per incubation time was calculated.

\section{Measurement of NER capacity upon oxidant exposure}

To assess the effects of oxidative stress on NER capacity, A549 cells were treated as described above. After the various incubation periods, trypsin was added to the cells and cells were counted and diluted to a final concentration of $5 \times 10^{6}$ cells $/ \mathrm{mL}$. Then, 1-2 $\mathrm{mL}$ of the cell suspension was centrifuged at $14,000 \mathrm{rpm}$ for 5 minutes and pellets were frozen at $-20^{\circ} \mathrm{C}$ until preparation of cell extracts. To asses NER capacity we applied a method that was recently developed in our laboratory [15]. Basically, this assay measures the ability of NER-related enzymes that are present 
in cell extracts, to incise substrate DNA containing benzo[a]pyrene-diolepoxide (BPDE)-DNA adducts. The substrate nucleoids were prepared from untreated A549 cells, which were embedded in agarose and subsequently lysed overnight in cold $\left(4^{\circ} \mathrm{C}\right)$ lysis buffer. The resulting nucleoids were then exposed to BPDE $(1 \mu \mathrm{M}$ in PBS) or vehicle control (DMSO, $0.5 \%$ ) for 30 minutes at $4^{\circ} \mathrm{C}$. To prepare cell extracts, frozen cell pellets were thawed and resuspended in buffer A (45 mM HEPES, $0.4 \mathrm{M} \mathrm{KCl}, 1 \mathrm{mM}$ EDTA, $0.1 \mathrm{mM}$ dithiothreitol, $10 \%$ glycerol, adjusted to $\mathrm{pH}$ 7.8 using $\mathrm{KOH}, 50 \mu \mathrm{L}$ per $5 \times 10^{6}$ cells). Resulting aliquots were snap-frozen, thawed again and lysis was completed by adding $15 \mu \mathrm{L}$ of $1 \%$ Triton X-100 in buffer $\mathrm{A}$. The lysate was centrifuged at $11,000 \mathrm{rpm}$ for 5 minutes at $4^{\circ} \mathrm{C}$. Next, protein concentrations were determined and cell extracts were diluted to a concentration of $1 \mathrm{mg} / \mathrm{mL}$, and stored at $-80^{\circ} \mathrm{C}$ overnight. The next day, diluted protein extracts were thawed and 4 volumes of reaction buffer $B$ ( $45 \mathrm{mM}$ HEPES, $0.25 \mathrm{mM}$ EDTA, $2 \%$ glycerol, $0.3 \mathrm{mg} / \mathrm{mL}$ BSA, adjusted to $\mathrm{pH} 7.8$ with $\mathrm{KOH}$ ) were added. From this mixture, $50 \mu \mathrm{L}$ aliquots were added to the gel-embedded nucleoids containing high levels of BPDE-DNA adducts, and incubated for 10 minutes on a heating plate at $37^{\circ} \mathrm{C}$. Alkaline treatment and electrophoresis, each 20 minutes, were conducted as in the standard comet assay. The increase in DNA breaks at 10 minutes, leading to increased tail moments, is indicative for the NER capacity of the cell extracts. After subtracting background levels from all data, the final repair capacity was calculated according to Langie et al. [15].

\section{Statistical analyses}

Results are presented as mean \pm standard deviation. A non-parametric MannWhitney U-test was performed to analyze differences in cell survival between samples exposed to $\mathrm{H}_{2} \mathrm{O}_{2}$ and unexposed samples (with or without $\mathrm{GSH}$ depletion). To examine differences in intracellular oxidative stress and NER capacities after exposure to $\mathrm{H}_{2} \mathrm{O}_{2}$ and/or BSO versus the control, one-way ANOVA was used with subsequent Dunnett correction for multiple comparisons. Differences in gene expression between the different NER-genes were analyzed by T-tests. Correlations between gene-expression and phenotypical DNA repair capacity were assessed by linear regression. Statistical analysis was performed using SPSS v.12.0.1. In each case, a P-value of $<0.05$ was considered statistically significant.

\section{Results}

\section{Cytotoxicity}

As cytotoxicity may directly affect gene transcription levels, we initially measured cytotoxicity of $\mathrm{H}_{2} \mathrm{O}_{2}$ with or without GSH depletion, to select for non-toxic $\mathrm{H}_{2} \mathrm{O}_{2}$ doses. Cell viability was determined after a 1 hour exposure to $\mathrm{H}_{2} \mathrm{O}_{2}$, with or without a preceding 24 hour treatment with $\mathrm{BSO}$. Dose-response curves of $\mathrm{H}_{2} \mathrm{O}_{2}$, with and 


\section{Chapter 3}

without pre-treatment to BSO, are shown in Figure 1. Exposure up to $250 \mu \mathrm{M} \mathrm{H}_{2} \mathrm{O}_{2}$ did not affect the viability of the A549 cells. BSO treatment by itself was not cytotoxic to the cells. However, pre-exposure to BSO significantly increased $\mathrm{H}_{2} \mathrm{O}_{2-}$ induced loss of viability at doses higher than $100 \mu \mathrm{M}$. Therefore, all next experiments were performed using the non-cytotoxic dose of $100 \mu \mathrm{M} \mathrm{H}_{2} \mathrm{O}_{2}$.

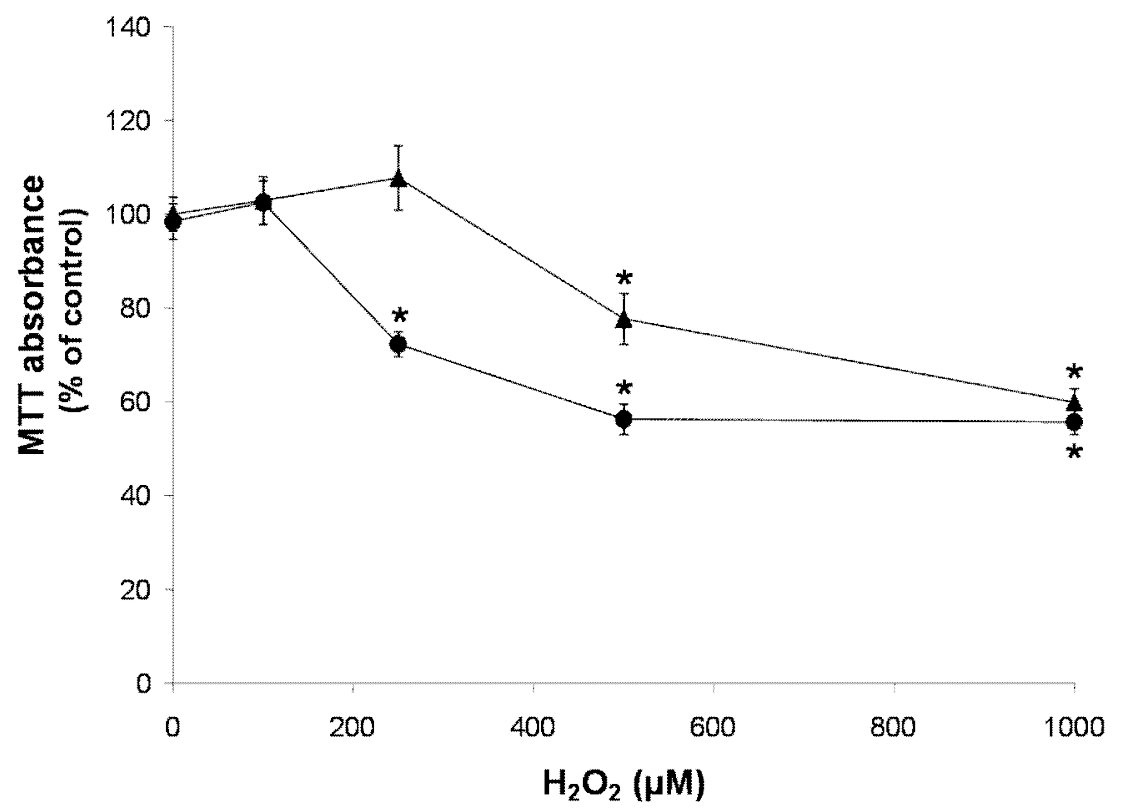

Figure 1. Cytotoxicity of $\mathrm{H}_{2} \mathrm{O}_{2}$ without pre-treatment with $\mathrm{BSO}(\boldsymbol{\Delta})$, and after preexposure to $500 \mu \mathrm{M}$ BSO $(\bullet)$. The mean cell viability $(n=5)$ is presented as MTT absorbance (\% of control). Bars represent standard deviations ( ${ }^{*} \mathrm{P}<0.01 ; \mathrm{H}_{2} \mathrm{O}_{2}$ exposed vs. non-exposed).

\section{Intracellular oxidative stress}

Rhodamine fluorescence was measured as an indicator for intracellular oxidative stress (Figure 2). Exposure of A549 cells to a non-cytotoxic dose of $100 \mu \mathrm{M} \mathrm{H} \mathrm{H}_{2} \mathrm{O}_{2}$ led to an increased level of intracellular oxidative stress. After GSH depletion, oxidative stress in the cells increased $\sim 3$-fold $(P=0.018)$. When $G S H$ depletion was followed by exposure to $\mathrm{H}_{2} \mathrm{O}_{2}$, intracellular oxidative stress was further increased $\sim 5$-fold $(\mathrm{P}<0.001)$. 


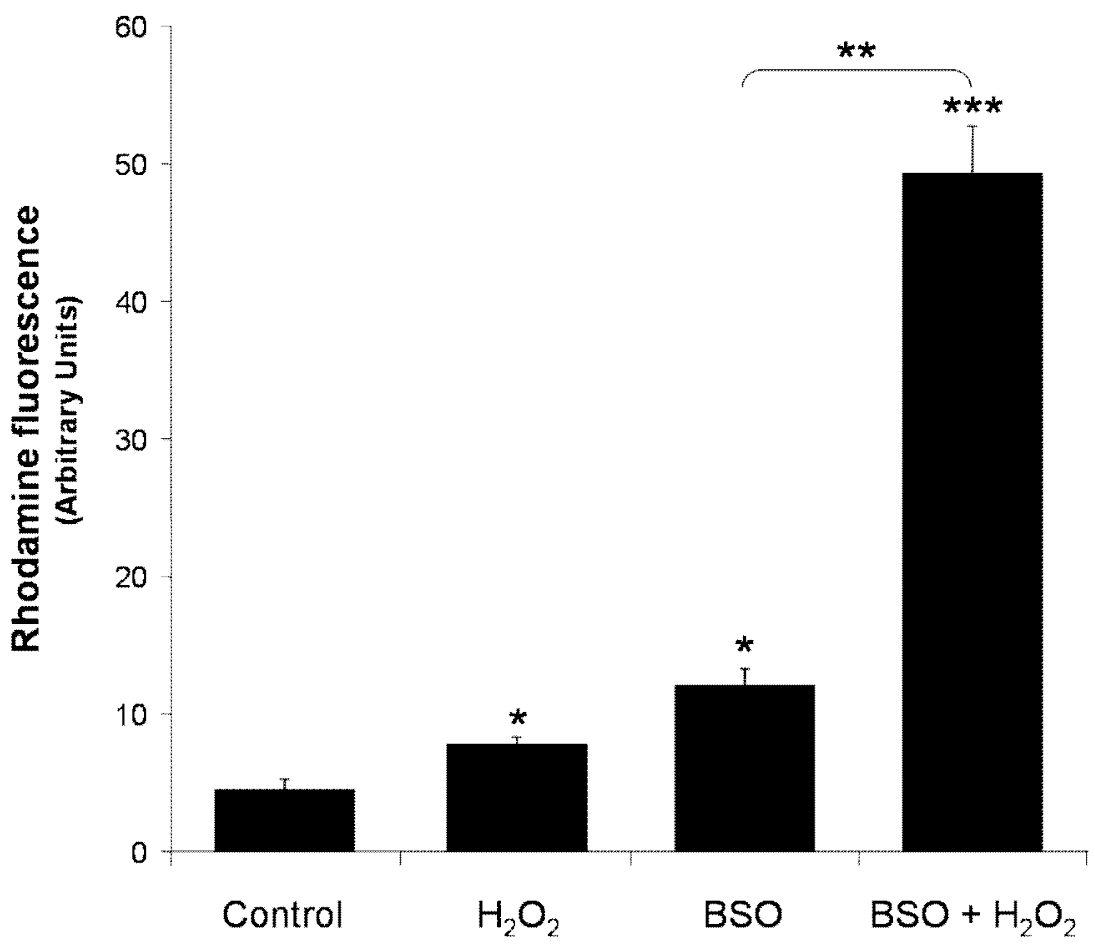

Figure 2. Increased intracellular oxidative stress by $\mathrm{H}_{2} \mathrm{O}_{2}$ and/or $\mathrm{BSO}$ exposure. Data are expressed as the mean rhodamine fluorescence ( \pm standard deviation) of two independent incubations ( ${ }^{*} \mathrm{P}<0.05$, ${ }^{* *} \mathrm{P}<0.001 ; \mathrm{H}_{2} \mathrm{O}_{2}$ and/or $\mathrm{BSO}$ exposed vs. controls, and ${ }^{* *} \mathrm{P}=0.001$; $\mathrm{GSH}$-depleted cells with vs. without subsequent $\mathrm{H}_{2} \mathrm{O}_{2}$ exposure).

\section{Gene expression profiles after oxidant exposure}

To test the effect of oxidative stress on expression of NER genes, A549 cells were exposed to $100 \mu \mathrm{M} \mathrm{H}_{2} \mathrm{O}_{2}$ and gene expression was determined by quantitative RTPCR. We specifically selected NER genes that encode proteins involved in the recognition and incision phase of NER, since these phases are assessed in our phenotypical NER capacity assay. XPA and XPC are involved in the recognition and verification of the damaged DNA [20]. ERCC1 and ERCC4 are 5'endonucleases, whereas ERCC5 possesses 3' endonuclease activity. After $\mathrm{H}_{2} \mathrm{O}_{2}$ exposure, a 2 to 4.5-fold increase in expression of XPA, XPC, ERCC4 and ERCC5 was observed, as compared to the control level (Figure $3 \mathrm{~A}, \mathrm{P}<0.05$ for all genes). The highest expression was observed for ERCC5, showing a peak at 8 hours post-exposure followed by a gradual decline back to basal levels at 24h. Surprisingly, expression of ERCC1 was $\sim 5$-fold down regulated by $\mathrm{H}_{2} \mathrm{O}_{2}$ exposure $(\mathrm{P}=0.01)$ with a subsequent increase in expression up to $\sim 2$ fold above the basal level at 24 hours after exposure. 


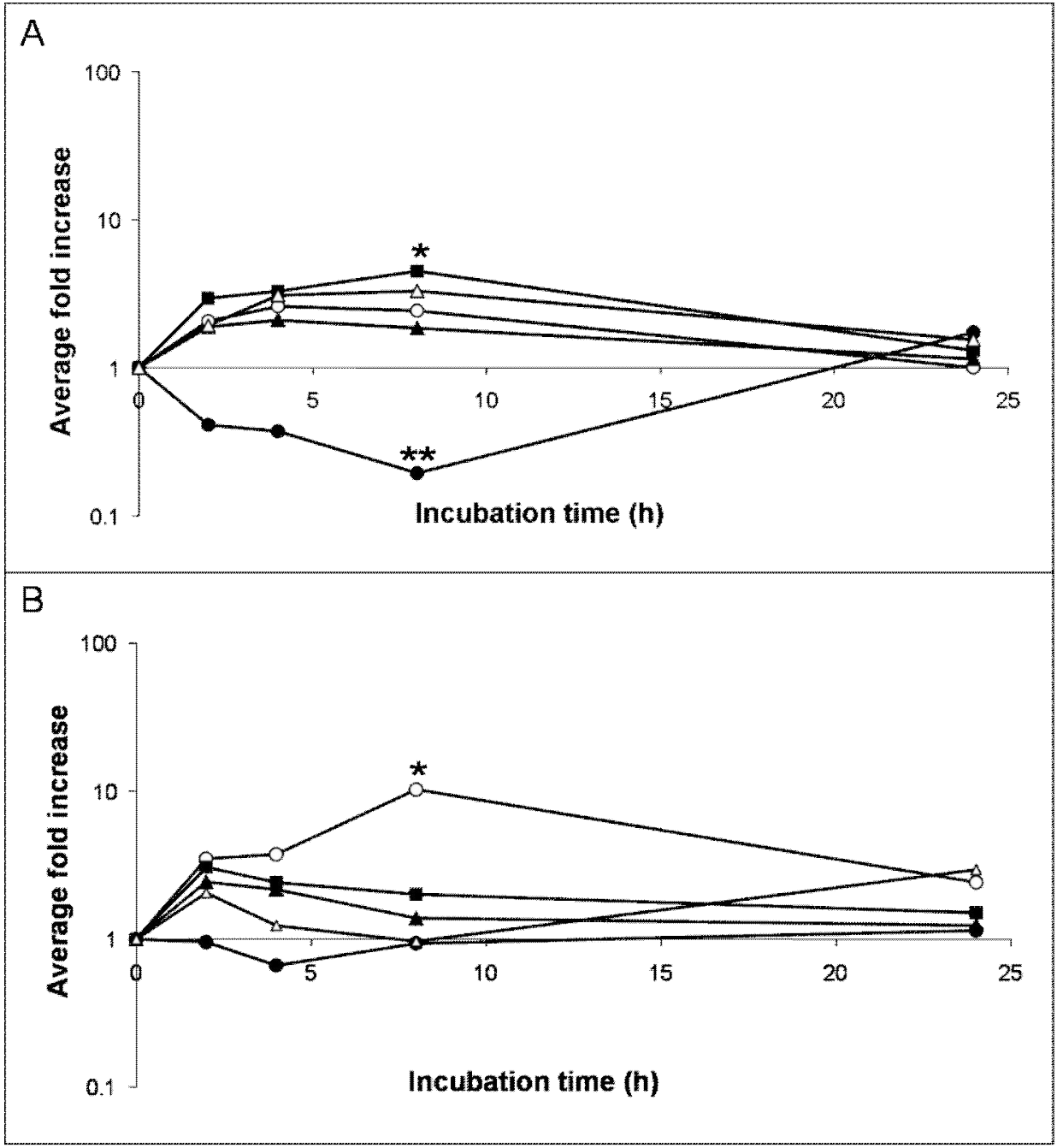

Figure 3. Gene expression profiles of XPA ( $\mathbf{\Delta}), X P C(\triangle), E R C C 1(\bullet), E R C C 4(\bigcirc)$ and ERCC5 (ם). A) Gene expression profiles after exposure of A549 cells to $100 \mu \mathrm{M} \mathrm{H}_{2} \mathrm{O}_{2}$. $\left({ }^{*} \mathrm{P}<0.05\right.$ for gene expression of ERCC5, ERCC4, XPA and XPC vs. controls, and ${ }^{* *} \mathrm{P}=0.01$ for ERCC1 gene expression vs. control) $\mathrm{B}$ ) Gene regulation patterns in $\mathrm{GSH}$ depleted cells, subsequently exposed to $\mathrm{H}_{2} \mathrm{O}_{2}\left({ }^{*} \mathrm{P}<0.05\right.$; ERCC4 gene expression vs. control). Data are shown as the average fold increase of two independent incubations within two separate experiments. No error bars were presented for better visualization. 
To study the role of GSH in this redox-regulation of NER-related genes, cells were pre-incubated with $500 \mu \mathrm{M}$ BSO for 24 hours. BSO induces intracellular oxidative stress by irreversibly inhibiting gamma-glutamylcysteine synthetase, an essential enzyme for the synthesis of GSH [21]. GSH is the most abundant natural anti-oxidant that reacts with ROS (mainly $\mathrm{H}_{2} \mathrm{O}_{2}$ ) in the cell, preventing damage to proteins or DNA. As a result, our initial hypothesis was that depletion of BSO would further enhance the $\mathrm{H}_{2} \mathrm{O}_{2}$-induced effects on NER gene expression. Indeed, the upregulation of ERCC4 expression was potentiated from 2.5 fold to $>10$ fold. However, the down-regulation of ERCC1 gene-expression by $\mathrm{H}_{2} \mathrm{O}_{2}$ was completely abolished (Figure 3B). The $\mathrm{H}_{2} \mathrm{O}_{2}$-induced expression of the remaining three genes was unaffected by $\mathrm{GSH}$ depletion.

Depletion of $\mathrm{GSH}$ by BSO for 24 hours (without additional exposure to $\mathrm{H}_{2} \mathrm{O}_{2}$ ) slightly induced the expression of ERCC1, ERCC5 and XPC (fold changes were $1.29 \pm 0.13,1.42 \pm 0.17$ and $1.20 \pm 0.42$, respectively) compared to un-depleted cells. On the other hand, the expression of XPC and ERCC4 was decreased (the fold change was 0.83 and 0.62 , respectively).

\section{NER capacity in cells with increased intracellular oxidative stress}

Phenotypical assessment of NER capacity by a modified comet-assay showed that NER activity rapidly decreased to less than $50 \%$ for up to 4 hours after $\mathrm{H}_{2} \mathrm{O}_{2}$ exposure $(P=0.04)$, followed by a minimal overcompensation at 24 hours post-exposure (Figure 4A). This acute decrease in NER capacity by $\mathrm{H}_{2} \mathrm{O}_{2}$ was completely absent in $\mathrm{GSH}$ depleted cells. In fact, GSH depletion by itself caused an induction of NER capacity of about $50 \%$ as compared to the control cells (i.e. no BSO and no $\mathrm{H}_{2} \mathrm{O}_{2}$ exposure). After addition of $\mathrm{H}_{2} \mathrm{O}_{2}$, this 1.5 fold increase in NER capacity in $\mathrm{GSH}$ depleted cells gradually declined back to basal levels at 24 hours (note that the medium was replaced at $\mathrm{t}=0 \mathrm{~h}$ and incubation was continued in absence of $\mathrm{BSO}$ ).

\section{ERCC1 expression correlates with NER capacity}

By comparing Figures 3 and 4 it is evident that the effects of $\mathrm{H}_{2} \mathrm{O}_{2}$ on NER capacity strongly paralleled the effects of $\mathrm{H}_{2} \mathrm{O}_{2}$ on ERCC1 gene expression. Similarly, the $\mathrm{H}_{2} \mathrm{O}_{2}$ induced decrease in NER capacity was, as for the ERCC1 expression, absent in GSH-depleted cells. To better visualize the possible relation between ERCC1 expression and NER capacity, the average fold changes of ERCC1 expression after the various oxidant exposures $\left(\mathrm{H}_{2} \mathrm{O}_{2}\right.$, BSO or $\left.\mathrm{BSO}+\mathrm{H}_{2} \mathrm{O}_{2}\right)$ were plotted against the corresponding DNA repair capacities (Figure 4B). A highly significant correlation between ERCC1 gene expression and DNA repair capacity was observed $\left(R^{2}=0.85\right.$, $\mathrm{P}<0.001)$. These data suggest that regulation of NER under conditions of oxidative stress is largely explained by effects on ERCC1 gene-transcription. 


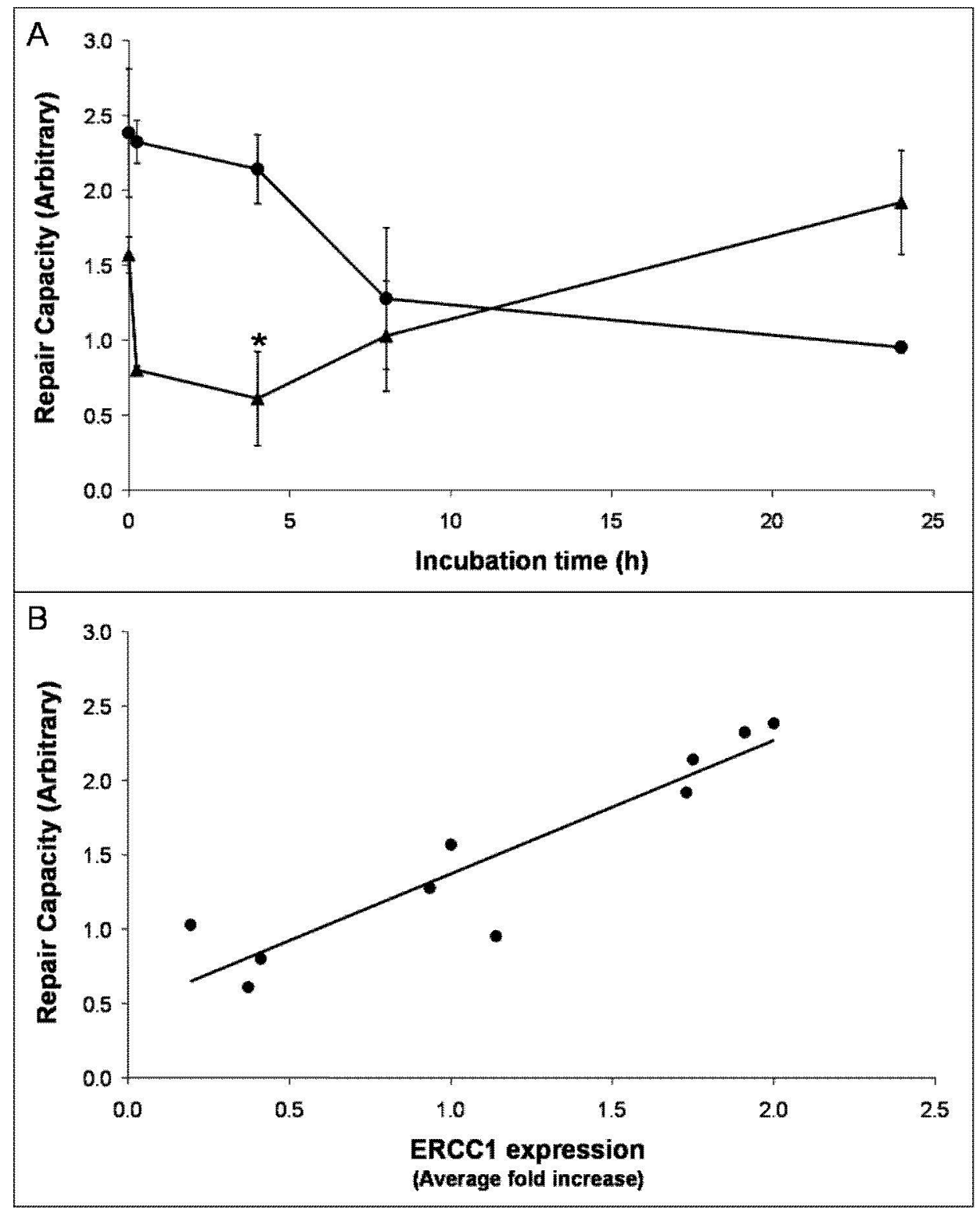

Figure 4. Redox-status modulated NER capacity, and its correlation with ERCC1 expression. A) The effect of $\mathrm{H}_{2} \mathrm{O}_{2}$ exposure on the NER capacity in $\mathrm{GSH}$-rich ( $\boldsymbol{\Delta}$ ), and in GSH-depleted cells $(\mathbf{O})$. Data are presented as the mean repair capacities $(n=3)$, calculated based on tail moment values. Bars indicate standard error of the mean ( ${ }^{*} \mathrm{P}<0.05$; NER capacity after $\mathrm{H}_{2} \mathrm{O}_{2}$ exposure vs. control). B) Relationship between ERCC1 expression and NER-related damage recognition and incision $\left(R^{2}=0.85\right.$, $\mathrm{P}<0.001)$. 


\section{Discussion}

\section{A role for GSH in the expression of NER genes}

The present study shows that the expression of NER genes, at least in an in vitro epithelial lung cell culture, can be modulated upon exposure to oxidative stress. Exposure to $\mathrm{H}_{2} \mathrm{O}_{2}$ resulted in the up-regulation of most of the selected NER genes. In contrast, the expression of ERCC1 was significantly down-regulated by $\mathrm{H}_{2} \mathrm{O}_{2}$. Interestingly, for most of the genes, the modulating effect of $\mathrm{H}_{2} \mathrm{O}_{2}$ was reduced when $\mathrm{GSH}$-depletion preceded $\mathrm{H}_{2} \mathrm{O}_{2}$ exposure, except for $E R C C 4$, for which $\mathrm{H}_{2} \mathrm{O}_{2}$ induced expression was further enhanced by $\mathrm{GSH}$-depletion. In general, this suggests that $\mathrm{H}_{2} \mathrm{O}_{2}$-induced regulation of NER gene transcription is mediated by $\mathrm{GSH}$. Recent studies of Fratelli et al. [22] already showed that some patterns of gene regulation as induced by exposure to $\mathrm{H}_{2} \mathrm{O}_{2}$ were $\mathrm{GSH}$-dependent. $\mathrm{GSH}$ is speculated to regulate genes in two ways. Either via its antioxidant and ROS scavenging function, or by influencing gene expression via protein glutathionylation, which is known to be induced by $\mathrm{H}_{2} \mathrm{O}_{2}[23,24]$.

In general, the observed gene expression responses of the five selected NER genes can be subdivided in three categories. (1) Up-regulation by $\mathrm{H}_{2} \mathrm{O}_{2}$ is further enhanced by GSH-depletion. This is illustrated by the expression kinetics of ERCC4. A possible explanation for this enhancement is the increased level of oxidative stress by $\mathrm{H}_{2} \mathrm{O}_{2}$ as a result of $\mathrm{GSH}$-depletion. It should be stressed, however, that exposure to $\mathrm{BSO}$ alone, which also induced intracellular oxidative stress, resulted in a down-regulation of ERCC4; (2) Down-regulation by $\mathrm{H}_{2} \mathrm{O}_{2}$ is inhibited by GSH-depletion. This is the case for ERCC1 expression, where GSHdepletion completely abolished the inhibitory effect of $\mathrm{H}_{2} \mathrm{O}_{2}$. ERCC1 was reported to have an AP-1 binding sequence in the promoter region. Therefore, we expected increased expression of ERCC1 after $\mathrm{H}_{2} \mathrm{O}_{2}$ treatment. However, Fratelli et al. [22] showed that the expression of the AP-1 subunits, Fos and FosB, was not induced by $\mathrm{H}_{2} \mathrm{O}_{2}$ alone, but was strongly induced in $\mathrm{GSH}$ depleted cells. Therefore, the restoration of ERCC1 expression in $\mathrm{GSH}$ depleted cells exposed to $\mathrm{H}_{2} \mathrm{O}_{2}$ may partly be explained by activation of this transcription factor. These findings suggest that GSH has a signaling role in the redox-regulated gene expression of NER genes. Further studies are needed to understand the underlying molecular mechanisms; (3) Up-regulation by $\mathrm{H}_{2} \mathrm{O}_{2}$ is minimally modified by $\mathrm{GSH}$-depletion. This refers to observations for XPA, XPC and ERCC5 showing an increased expression upon exposure to $\mathrm{H}_{2} \mathrm{O}_{2}$, with no obvious effects other than a shift of the highest induction towards earlier time points by BSO pre-exposure. Finally, it should be stressed that, in addition to direct oxidative regulation of gene expression, as discussed above, part of the $\mathrm{H}_{2} \mathrm{O}_{2}$-induced gene expression effects may also be explained by DNA damage responsive processes induced by $\mathrm{H}_{2} \mathrm{O}_{2}$-related induction of DNA damage. 


\section{Oxidative effects on nucleotide excision repair capacity correlate with ERCC1 expression}

In the present study, we specifically selected NER genes that encode proteins involved in the recognition and incision phase of NER, because these phases are reflected in our NER capacity assay. While the major function of NER is to repair bulky DNA adducts, components of this machinery may also have a role in repair of oxidative DNA damage $[8,10]$. Since most of the selected NER genes showed an increased expression upon exposure to $\mathrm{H}_{2} \mathrm{O}_{2}$, the overall effect of the oxidant treatments was expected to result in an increase of NER capacity as measured by the repair assay. Surprisingly, we observed an acute inhibition of nucleotide excision repair capacity after exposure to $\mathrm{H}_{2} \mathrm{O}_{2}$. This is in line with studies from Hu et al. [25] who revealed that $\mathrm{H}_{2} \mathrm{O}_{2}$ can have suppressive effects on unscheduled DNA repair, suggestive of suppressed NER. Our observations are further supported by other studies showing that oxidants, including 4-hydroxynonenal, malondialdehyde and monochloramine, can be potent inhibitors of NER, most likely by direct oxidative attack and inactivation of NER proteins [26-28]. Oxidative stress can indeed directly influence enzyme activity, for instance by oxidation of GSH and protein thiols, two important factors involved in mediating DNA repair enzyme activity $[29,30]$. The restoration of this acutely $\mathrm{H}_{2} \mathrm{O}_{2}$-suppressed NER activity in time, as shown in Figure 4 , is most likely explained by affecting signal transduction pathways and gene transcription, leading to de-novo synthesis of NER related proteins. Our data further show that total depletion of GSH, resulted in a $50 \%$ increase in NER activity. This is in line with previous studies, showing increased activity of NER after pre-treatment with BSO [31], and possibly explains the absence of suppressed NER activity as observed upon exposure to $\mathrm{H}_{2} \mathrm{O}_{2}$.

Our study shows that ERCC1 is a major determinant of NER capacity. For the incision activity of ERCC1, heterodimer formation with ERCC4 (XPF) is needed [20]. However, ERCC1 and ERCC4 expression were not correlated in the present study, which is consistent with previous observations by Vogel et al. [32]. Combining all data, we found a highly significant correlation between NER capacity and ERCC1 gene expression $\left(R^{2}=0.85, P<0.01\right)$. This is consistent with previous studies reporting a positive correlation between repair capacity and ERCC1 expression [3234]. Overall, these data suggests that ERCC1 expression is a crucial target for redox-regulated NER capacity and, in addition, can be a proxy for repair capacity.

\section{Acknowledgements}

This work was supported by the European network of excellence ECNIS (FOOD-CT2005-513943) on Environmental Cancer risk, Nutrition and Individual Susceptibility. A.M. Knaapen is supported by a postdoctoral fellowship from the Netherlands Organisation for Scientific Research (NWO, VENI-916.46.092). 


\section{References}

1. Ames B. N. Endogenous oxidative DNA damage, aging, and cancer. Free Radic Res Commun 1989;7:121-128.

2. Cooke M. S., Evans M. D., Dizdaroglu M. and Lunec J. Oxidative DNA damage: mechanisms, mutation, and disease. Faseb J 2003;17:1195-1214.

3. Floyd R. A. Role of oxygen free radicals in carcinogenesis and brain ischemia. Faseb J 1990;4:2587-2597.

4. Cadet J., Bourdat A. G., D'Ham C., Duarte V., Gasparutto D., Romieu A. and Ravanat J. L. Oxidative base damage to DNA: specificity of base excision repair enzymes. Mutat Res 2000;462:121-128.

5. Seeberg E., Eide L. and Bjoras M. The base excision repair pathway. Trends Biochem Sci 1995;20:391-397.

6. Tuo J., Jaruga P., Rodriguez H., Bohr V. A. and Dizdaroglu M. Primary fibroblasts of Cockayne syndrome patients are defective in cellular repair of 8-hydroxyguanine and 8-hydroxyadenine resulting from oxidative stress. Faseb $\mathrm{J}$ 2003;17:668-674.

7. D'Errico M., Parlanti E., Teson M., de Jesus B. M., Degan P., Calcagnile A., Jaruga P., Bjoras M., Crescenzi M., Pedrini A. M., Egly J. M., Zambruno G., Stefanini M., Dizdaroglu M. and Dogliotti E. New functions of XPC in the protection of human skin cells from oxidative damage. Embo J 2006;25:4305-4315.

8. Slupphaug G., Kavli B. and Krokan H. E. The interacting pathways for prevention and repair of oxidative DNA damage. Mutat Res 2003;531:231-251.

9. Gellon L., Barbey R., Auffret van der Kemp P., Thomas D. and Boiteux S. Synergism between base excision repair, mediated by the DNA glycosylases Ntg1 and Ntg2, and nucleotide excision repair in the removal of oxidatively damaged DNA bases in Saccharomyces cerevisiae. Mol Genet Genomics 2001;265:10871096.

10. Reardon J. T., Bessho T., Kung H. C., Bolton P. H. and Sancar A. In vitro repair of oxidative DNA damage by human nucleotide excision repair system: possible explanation for neurodegeneration in xeroderma pigmentosum patients. Proc Natl Acad Sci U S A 1997;94:9463-9468.

11. Klungland A., Hoss M., Gunz D., Constantinou A., Clarkson S. G., Doetsch P. W., Bolton P. H., Wood R. D. and Lindahl T. Base excision repair of oxidative DNA damage activated by XPG protein. Mol Cell 1999;3:33-42.

12. Dusinska M., Dzupinkova Z., Wsolova L., Harrington V. and Collins A. R. Possible involvement of XPA in repair of oxidative DNA damage deduced from analysis of damage, repair and genotype in a human population study. Mutagenesis 2006;21:205-211.

13. Li Q., Zhang L., Tsang B., Gardner K., Bostick-Bruton F. and Reed E. Phorbol ester exposure activates an AP-1-mediated increase in ERCC-1 messenger RNA expression in human ovarian tumor cells. Cell Mol Life Sci 1999;55:456-466.

14. Li Q., Ding L., Yu J. J., Mu C., Tsang B., Bostick-Bruton F. and Reed E. Cisplatin and phorbol ester independently induce ERCC-1 protein in human ovarian carcinoma cells. Int J Oncol 1998;13:987-992.

15. Langie S. A., Knaapen A. M., Brauers K. J., van Berlo D., van Schooten F. J. and Godschalk R. W. Development and validation of a modified comet assay to phenotypically assess nucleotide excision repair. Mutagenesis 2006;21:153-158.

16. Mosmann T. Rapid colorimetric assay for cellular growth and survival: application to proliferation and cytotoxicity assays. J Immunol Methods 1983;65:55-63.

17. Borm P. J., Knaapen A. M., Schins R. P., Godschalk R. W. and Schooten F. J. Neutrophils amplify the formation of DNA adducts by benzo[a]pyrene in lung target cells. Environ Health Perspect 1997;105 Suppl 5:1089-1093.

18. Henderson L. M. and Chappell J. B. Dihydrorhodamine 123: a fluorescent probe for superoxide generation? Eur J Biochem 1993;217:973-980. 


\section{Chapter 3}

19. Livak K. J. and Schmittgen T. D. Analysis of relative gene expression data using real-time quantitative PCR and the 2(-Delta Delta C(T)) Method. Methods 2001;25:402-408.

20. Wood R. D., Araujo S. J., Ariza R. R., Batty D. P., Biggerstaff M., Evans E., Gaillard P. H., Gunz D., Koberle B., Kuraoka I., Moggs J. G., Sandall J. K. and Shivji M. K. DNA damage recognition and nucleotide excision repair in mammalian cells. Cold Spring Harb Symp Quant Biol 2000;65:173-182.

21. Griffith O. W. Mechanism of action, metabolism, and toxicity of buthionine sulfoximine and its higher homologs, potent inhibitors of glutathione synthesis. $J$ Biol Chem 1982;257:13704-13712.

22. Fratelli M., Goodwin L. O., Orom U. A., Lombardi S., Tonelli R., Mengozzi M. and Ghezzi P. Gene expression profiling reveals a signaling role of glutathione in redox regulation. Proc Natl Acad Sci U S A 2005;102:13998-14003.

23. Fratelli M., Demol H., Puype M., Casagrande S., Eberini I., Salmona M., Bonetto V., Mengozzi M., Duffieux F., Miclet E., Bachi A., Vandekerckhove J., Gianazza E. and Ghezzi P. Identification by redox proteomics of glutathionylated proteins in oxidatively stressed human $T$ lymphocytes. Proc Natl Acad Sci $U S A$ 2002;99:3505-3510.

24. Fratelli M., Demol H., Puype M., Casagrande S., Villa P., Eberini I., Vandekerckhove J., Gianazza E. and Ghezzi P. Identification of proteins undergoing glutathionylation in oxidatively stressed hepatocytes and hepatoma cells. Proteomics 2003;3:1154-1161.

25. Hu J. J., Dubin N., Kurland D., Ma B. L. and Roush G. C. The effects of hydrogen peroxide on DNA repair activities. Mutat Res 1995;336:193-201.

26. Feng Z., Hu W. and Tang M. S. Trans-4-hydroxy-2-nonenal inhibits nucleotide excision repair in human cells: a possible mechanism for lipid peroxidation-induced carcinogenesis. Proc Natl Acad Sci U S A 2004;101:8598-8602.

27. Feng Z., Hu W., Marnett L. J. and Tang M. S. Malondialdehyde, a major endogenous lipid peroxidation product, sensitizes human cells to UV- and BPDEinduced killing and mutagenesis through inhibition of nucleotide excision repair. Mutat Res 2006.

28. Hiramatsu K., Ogino T., Ozaki M. and Okada S. Monochloramine inhibits ultraviolet B-induced p53 activation and DNA repair response in human fibroblasts. Biochim Biophys Acta 2006;1763:188-196.

29. Cesarone C. F., Scovassi A. I., Scarabelli L., Izzo R., Orunesu M. and Bertazzoni $U$. Depletion of adenosine diphosphate-ribosyl transferase activity in rat liver during exposure to N-2-acetylaminofluorene: effect of thiols. Cancer Res 1988;48:35813585.

30. Krokan H., Grafstrom R. C., Sundqvist K., Esterbauer H. and Harris C. C. Cytotoxicity, thiol depletion and inhibition of O6-methylguanine-DNA methyltransferase by various aldehydes in cultured human bronchial fibroblasts. Carcinogenesis 1985;6:1755-1759.

31. Reliene R. and Schiestl R. H. Glutathione depletion by buthionine sulfoximine induces DNA deletions in mice. Carcinogenesis 2006;27:240-244.

32. Vogel U., Dybdahl M., Frentz G. and Nexo B. A. DNA repair capacity: inconsistency between effect of over-expression of five NER genes and the correlation to mRNA levels in primary lymphocytes. Mutat Res 2000;461:197-210.

33. Wei Q., Xu X., Cheng L., Legerski R. J. and Ali-Osman F. Simultaneous amplification of four DNA repair genes and beta-actin in human lymphocytes by multiplex reverse transcriptase-PCR. Cancer Res 1995;55:5025-5029.

34. Dabholkar M. D., Berger M. S., Vionnet J. A., Egwuagu C., Silber J. R., Yu J. J. and Reed E. Malignant and nonmalignant brain tissues differ in their messenger RNA expression patterns for ERCC1 and ERCC2. Cancer Res 1995;55:1261-1266. 




\section{Chapter 4}

\section{In vivo dietary modulation of nucleotide excision repair in colon tissue of newborn piglets}

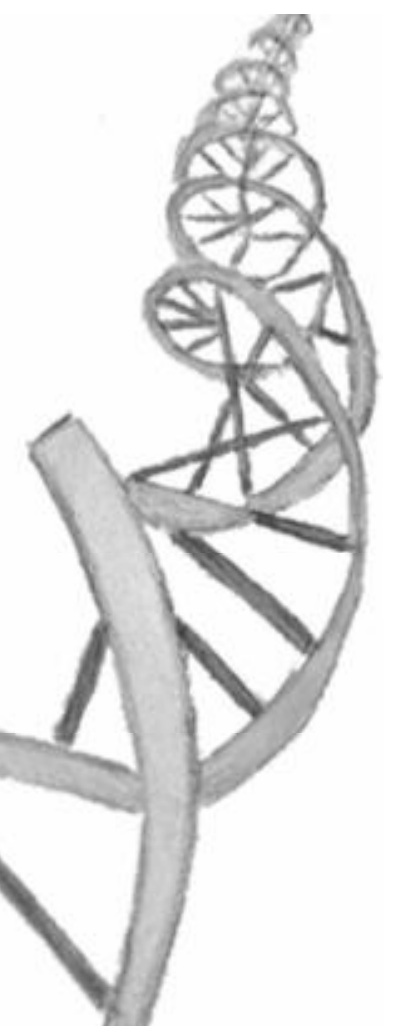

Submitted

Sabine A.S. Langie Pawel Kowalczyk Barbara Tudek Romuald Zabielski Tomasz Dziaman Ryszard Oliński

Frederik J. van Schooten Roger W.L. Godschalk 


\section{Chapter 4}

\section{Abstract}

Nucleotide excision repair (NER) is important for the maintenance of genomic integrity, but is inhibited by oxidative stress. Dietary antioxidants could thus protect DNA by reducing the formation of oxidative DNA damage, but also by protecting NER against oxidative stress induced inhibition. To obtain further insight in the relation between oxidative stress and NER activity in vivo, the redox status in newborn piglets was modulated by intramuscular injection of iron at day 3 after birth. Indeed, injection of iron significantly increased 8-oxo-7,8-dihydro-2'-deoxyguanosine (8-oxodG) levels in colon and urine at day 7-14 after birth. In parallel, the influence of maternal dietary supplementation with antioxidants was investigated in their offspring. Supplementation resulted in reduced iron concentrations in colon $(P=0.004)$ at day 7 and a $40 \%$ reduction of 8 -oxodG in colon DNA $(P=0.044)$ at day 14 after birth. NER capacity in animals that did not receive antioxidants was significantly reduced to $32 \%$ at day 7 as compared to the initial NER capacity on day 1 after birth. This reduction of NER capacity was less pronounced in antioxidant supplemented piglets (69\%). Overall, these data indicate that NER can be modulated by oxidative stress in vivo, which can be compensated for by antioxidant supplementation. 


\section{Introduction}

The general population is constantly exposed to environmental carcinogens that may cause damage to a variety of molecular targets including DNA. If these DNA lesions are not removed by DNA repair mechanisms in time, they can become selfperpetuating mutations that contribute to ageing and human degenerative diseases such as cancer [1-3]. As such, DNA repair impairment is an important risk factor in the pathogenesis of certain diseases. One of the major DNA repair processes is nucleotide excision repair (NER), which is involved in the removal of bulky-DNA adducts resulting from exposure to chemical carcinogens like polycyclic aromatic hydrocarbons.

An important modulator of DNA repair activity seems to be oxidative stress, which results from an imbalance between formation of reactive oxygen species (ROS) and the available antioxidant defences. ROS are produced as a consequence of normal cellular metabolism, but may also arise from pathological processes and extra-cellular sources. Furthermore, it has been shown that these ROS and reactive nitrogen species (RNS) can affect transcription of repair enzymes, but may also directly inactivate repair enzymes by oxidation and nitrosation, respectively. For example, exogenous nitric oxide and peroxynitrite have been shown to inhibit OGG1 [4], DNA ligase [5], formamidopyrimidine-DNAglycosylase [6], and O6-alkylguanine-DNA-alkyltransferase by direct nitrosylation [7]. Moreover, in one of our previous studies, the regulation of NER was also at least partly controlled by oxidative stress mediators in vitro [8]. A balance between oxidants and antioxidants is thus crucial to prevent oxidative stress and subsequent adverse effects on DNA repair processes.

Therefore, we hypothesize that oxidative stress reduces nucleotide excision repair capacities in vivo and that an antioxidant rich diet can compensate for these effects. The in vivo model used in this study was newborn piglets, because of their similarities to humans regarding: i) morphology and function of organs, ii) oxidative DNA damage removal, and iii) metabolic rates $[9,10]$. Newborns were chosen because their antioxidant systems, as in humans and other mammals, are shown to be poorly developed and thus oxidative stress can be modulated more easily $[11,12]$. Furthermore, in this particular study the colon was selected as target organ, because DNA damage caused by ROS is a major contributor to colorectal cancer [13] and colon cancer is the third most commonly occurring cancer in both men and women [14-16]. To induce high levels of oxidative stress, newborn piglets were intra-muscularly injected with iron on day 3 post-partum, which is known to catalyze the generation of ROS [17]. Note that this is a standard procedure found in every production farm worldwide, though, in our study design it was considered as an oxidative stress inducer. In parallel, the influence of supplementation of mother sows with an antioxidant rich diet, from day 80 of pregnancy until the end of the study at day 14 post-partum, was investigated on oxidative stress parameters and the modulation of DNA repair capacity (DRC) in the newborn offspring. Oxidative 


\section{Chapter 4}

stress was determined by assessing levels of the most commonly studied oxidative DNA lesion 8-oxo-7,8-dihydro-2'-deoxyguanosine (8-oxodG) in colon tissues and by measuring urinary excretion of 8-oxodG. Effects on NER capacity were assessed by a modified alkaline comet assay, which relies on the ability of protein/enzyme extracts to recognize and incise DNA substrates containing bulky lesions induced by benzo[a]pyrene-diol-epoxide (BPDE) [18].

\section{Materials and Methods}

\section{Chemicals}

Dulbecco's Modified Eagles Medium (DMEM), Tris, KAc, alkaline phosphatase, (low melting point $=$ LMP) agarose, TritonX-100, glycerol and BSA were obtained from Sigma (St. Louis, USA). Fetal Calf Serum (FCS), trypsin, TRIzol, Hanks Balanced Salt Solution (HBSS; with and without $\mathrm{Ca} / \mathrm{Mg}$ ), Penicillin/streptomycin and ethidium bromide were purchased from Gibco Invitrogen (Scotland, UK). Benzo[a]pyrene-7,8dihydrodiol-9,10-epoxide (BPDE) was obtained from $\mathrm{NCl}$ Chemical Carcinogen Reference Standard Repository (Midwest Research Institute, Kansas City). Dimethyl sulfoxide (DMSO), EDTA, DTT, SDS, $\mathrm{H}_{2} \mathrm{O}_{2}, \mathrm{KOH}, \mathrm{KCL}, \mathrm{NaOH}, \mathrm{NaCl}$, chloroform, iso-propanol, ethanol and mercapto-ethanol were obtained from Merck (Germany). Proteinase K and RNase were supplied by Roche (New York, USA).

\section{Animals and design of the study}

The experiments described here were conducted in compliance with the European Union regulations concerning the protection of experimental animals. The study protocol was approved in advance by the Local Ethical Committee, WULS, Warsaw, Poland. Care of the animals during the duration of the study was in accordance with the committee guidelines. A total of 12 pregnant sows (Sus scrofa domesticus, Landrace $x$ Pietrain) were kept in standard farm conditions (state farm Dobrzyniewo, Poland) with approximate $70 \%$ humidity and a temperature of $22 \pm 2{ }^{\circ} \mathrm{C}$ in standard cages with straw bedding. At day 80 of the pregnancy the sows were randomly divided into 2 groups, control $(n=6)$ and supplemented with antioxidant rich food ingredients $(n=6)$. The sows from the control group were fed with the standard diet for pregnant (dry matter (DM) 87.6\%, mean energy (ME) $11.35 \mathrm{MJ} / \mathrm{kg}$, crude protein (CP) 13.1\%) and lactating (DM 87.3\%, ME $12.93 \mathrm{MJ} / \mathrm{kg}, \mathrm{CP} 15.4 \%$ ) sows. The sows from the supplemented group received the standard diet for pregnant and lactating sows supplemented with a blend of substances (Table I) that contribute to an increased antioxidant status. This blend contained taurine (Otis, Poland), L-carnitine (Lonza, Poland), tocopherol acetate (Sigma-Aldrich, Poland), flaxseed and rapeseed providing $\alpha$-linolenic $(\mathrm{C} 18: 3 n-3)$ and linoleic $(\mathrm{C} 18: 2 n-6)$ fatty acids, and linden inflorescence (Kawon, Poland) as a source of flavonoids and other antioxidants, e.g. phenolic acids. The supplementation diet was modified in such a 
way that energy and protein content was similar to that in the control diet as published before $[19,20]$. Blood plasma, colostrum and milk analysis demonstrated substantial transfer of $\mathrm{n}-3$ fatty acids, plant polyphenols and other antioxidants from the supplemented diet into sow blood and milk. Only plasma and milk concentrations of carnithine were found not to be influenced $[19,20]$. Sows were supplemented from day 80 of pregnancy (pregnancies in pigs have duration of approx. 115 days) up to the 14th day of lactation. Fresh diet and water were provided each day ad libitum.

Table I. The composition of the standard diet and the bioactive substances used for supplementation of pregnant and lactating sows, in $\mathrm{g}$ per $1 \mathrm{~kg}$ of feed.

\begin{tabular}{lccc}
\hline & & \multicolumn{2}{c}{ Supplemented Sows } \\
\cline { 3 - 4 } Component ( $\mathrm{g} / \mathrm{kg}$ feed) & Control Sows & $\begin{array}{c}\text { Pregnant } \\
\text { (from day 80) }\end{array}$ & $\begin{array}{c}\text { Lactating } \\
\text { (from day 115) }\end{array}$ \\
\hline Soya & 125.00 & 90.00 & 90.00 \\
Barley & 300.00 & 255.00 & 255.00 \\
Triticale & 300.00 & 300.00 & 300.00 \\
Wheal & 245.00 & 245.00 & 245.00 \\
SAUENDOLD LA & 30.00 & 30.00 & 30.00 \\
& & & \\
Flax (Linum usitatissimuim L.) seed & & 40.00 & 40.00 \\
Rapeseed & & 40.00 & 40.00 \\
Linden (Tilia cordata) inflorescence & & 1.00 & 1.00 \\
Taurine & & 0.50 & 1.00 \\
L-carnitine & & 0.05 & 0.12 \\
Tocopherol acetate & & 0.15 & 0.15 \\
\hline
\end{tabular}

Piglets were delivered at term and clinically healthy. The average number of delivered piglets was 11.3 and 10.5 per sow, respectively, in the control and supplemented group $(\mathrm{P}=0.88)$. On day 3 post-partum the piglets were intramuscularly injected with $200 \mathrm{mg}$ iron dextran (FeDex), which is considered a traditional treatment in the swine industry to prevent anaemia. One piglet from each litter was sacrificed for tissue sampling by $\mathrm{CO}_{2}$ inhalation on postnatal days 1,2 (before FeDex injection), 4, 7, and 14. Piglets sacrificed at day one after birth represent the unsuckling newborns that did not receive FeDex injection and thus serve as untreated controls. A schematic overview of the study design is shown in Figure 1. Urine was collected by urinary bladder puncture and samples were stored at $-80^{\circ} \mathrm{C}$ until analyses. Colon tissue was isolated, snap frozen and stored at $-80^{\circ} \mathrm{C}$. Tissues were subsequently grinded using mortar and tamper that were cooled in liquid nitrogen. Grinded tissues were divided over eppendorf tubes containing 50$100 \mathrm{mg}$ of tissue, snap frozen and stored at $-80^{\circ} \mathrm{C}$ until analysis of the repair capacities or 8-oxodG levels. 


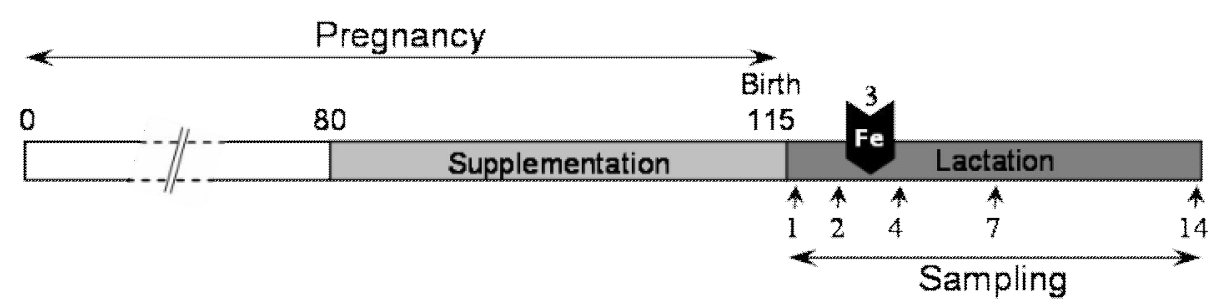

Figure 1. Schematic overview of supplementation and sampling time points. Dietary intervention of mother sows started at day 80 of the pregnancy and continued until day 14 of lactation. After birth, newborn piglets from the control as from the supplemented group were injected with $200 \mathrm{mg}$ of iron dextran. At days 1, 2, 4, 7 and 14 after birth newborn piglets were sacrificed, and urine samples and tissues were collected.

\section{Measurement of iron levels in colon tissue}

Total amounts of iron were measured in pig colon tissues by atomic absorption spectrometry. Grinded tissues ( $n=3-9$ per group per day) were hydrolyzed overnight in $1 \mathrm{~mL}$ of $7 \mathrm{M} \mathrm{HNO}_{3}$ at $60^{\circ} \mathrm{C}$. After centrifugation, $20 \mu \mathrm{L}$ of the supernatant was directly injected into a graphite furnace atomic absorption spectrometer with Zeeman background correction (Varian, Bergen op Zoom, The Netherlands). Fe concentrations $(\mathrm{ng} / \mathrm{mL})$ were determined at $372 \mathrm{~nm}$. Solutions with known concentrations of $\mathrm{Fe}$ were used for calibration. All the glassware was rinsed with $1 \%$ $\mathrm{HNO}_{3}$ to avoid contamination. Total Fe-concentration in $\mathrm{ng}$ Fe per mg colon tissue was calculated from the calibration curves and the weight of tissue.

\section{Determination of 8-oxodG in colon tissues}

To detect the base oxidation product 8-oxodG, HPLC with electrochemical detection (ECD) was performed. Grinded frozen colon tissues (50-100 mg, n=3-4 per group per day) were thawed and genomic DNA was obtained using standard phenol extraction [21]. The DNA extraction procedure was optimized to minimize artificial induction of 8-oxodG, by using radical-free phenol, minimizing exposure to oxygen and by addition of $1 \mathrm{mM}$ deferoxamine mesylate and $20 \mathrm{mM}$ TEMPO (2,2,6,6tetramethylpiperidine- $N$-oxyl), according to the European Standards Committee on Oxidative DNA Damage (ESCODD, ref [22]). DNA concentrations were quantified by spectrophotometry and samples were frozen at $-20^{\circ} \mathrm{C}$ until further use. HPLCECD of 8-oxodG was based on a method described earlier [23]. Briefly, $30 \mu \mathrm{g}$ DNA was digested to deoxyribonucleosides by treatment with, $6 \mu \mathrm{L} 0.5 \mathrm{M} \mathrm{NaAc}, 9 \mu \mathrm{L}$ $10 \mathrm{mM} \mathrm{ZnCl}_{2}$ and $1.5 \mu \mathrm{L}$ nuclease P1 (stock: $1 \mathrm{U} / \mu \mathrm{L}$ ), and incubation for $90^{\prime}$ at $37^{\circ} \mathrm{C}$. Subsequently, $30 \mu \mathrm{L} 0.5 \mathrm{M}$ Tris- $\mathrm{HCl}(\mathrm{pH} 7.4)$ and $1.5 \mu \mathrm{L}$ alkali phosphatase $(0.014$ $\mathrm{U} / \mu \mathrm{L}$ ) was added followed by incubation at $37^{\circ} \mathrm{C}$ for 45 '. The digest was then analysed by HPLC-ECD, using a Supelcosil ${ }^{\mathrm{TM}}$ LC-18S column $(250 \times 4.6 \mathrm{~mm})$ (Supelco Park, Bellefonte, PA) and a DECADE electrochemical detector (Antec, Leiden, The Netherlands). The ECD-signal was first stabilized with mobile phase 
(94mM KH $\mathrm{PO}_{4}, 13 \mathrm{mM} \mathrm{K}_{2} \mathrm{HPO}_{4}, 26 \mathrm{mM} \mathrm{KCL}$ and $0.5 \mathrm{mM}$ EDTA, $10 \%$ methanol) for approximately 3 hours at a flow rate of $1 \mathrm{~mL} / \mathrm{min}$. After stabilization, 8-oxodG was detected at a potential of $400 \mathrm{mV}$ and dG was simultaneously monitored by UV absorption at $260 \mathrm{~nm}$.

\section{Measurement of NER capacity in colon tissues}

To asses the effects of dietary supplementation with an antioxidant rich diet on NER capacity in the piglets' colon tissues, we applied a modified comet assay [18]. Basically, this assay measures the ability of NER-related enzymes that are present in cell/tissue extracts, to incise substrate DNA containing benzo[a]pyrenediolepoxide (BPDE)-DNA adducts. The substrate nucleoids were prepared from untreated A549 cells (human epithelial lung carcinoma cells), which were purchased from the American Tissue Culture Collection (ATCC) and were cultured in T75 flasks in DMEM supplemented with $10 \%$ heat inactivated FCS and $1 \%$ penicillin/streptomycin. Cells were maintained at $37^{\circ} \mathrm{C}$ in a $5 \% \mathrm{CO}_{2}$ atmosphere. A549 cells were tripsinized at approximately $80 \%$ confluency, embedded in LMP agarose and subsequently lysed overnight in cold $\left(4^{\circ} \mathrm{C}\right)$ lysis buffer $(2.5 \mathrm{M} \mathrm{NaCl}$, 0.1M EDTA, 0.01M Tris, 0.25M NaOH plus $1 \%$ Triton $\mathrm{X}-100$ and $10 \%$ DMSO added just before use). The resulting nucleoids were then exposed to BPDE ( $1 \mu \mathrm{M}$ in PBS) or vehicle control (DMSO, $0.5 \%$ ) for 30 minutes at $4^{\circ} \mathrm{C}$. To prepare protein/enzyme extracts, $50-100 \mathrm{mg}$ of grinded frozen colon tissues were thawed and resuspended in buffer A (45 mM HEPES, $0.4 \mathrm{M} \mathrm{KCl,} 1 \mathrm{mM}$ EDTA, $0.1 \mathrm{mM}$ dithiothreitol, 10\% glycerol, adjusted to $\mathrm{pH} 7.8$ using $\mathrm{KOH}, 100 \mu \mathrm{L}$ per $50 \mathrm{mg}$ tissue). Resulting aliquots were snap-frozen, thawed again and lysis was completed by adding $30 \mu \mathrm{L}$ of $1 \%$ Triton $\mathrm{X}-100$ in buffer A per $100 \mu \mathrm{L}$ of extract. The lysate was centrifuged at $11,000 \mathrm{rpm}$ for 5 minutes at $4^{\circ} \mathrm{C}$. Next, protein concentrations were determined by means of the BioRAD DC protein assay (Veenendaal, The Netherlands), using bovine serum albumin as a standard. Then tissue extracts were diluted to a concentration of $0.3 \mathrm{mg} / \mathrm{mL}$, and stored at $-80^{\circ} \mathrm{C}$ overnight. The next day, diluted protein extracts were thawed and 4 volumes of reaction buffer $B$ ( 45 mM HEPES, $0.25 \mathrm{mM}$ EDTA, $2 \%$ glycerol, $0.3 \mathrm{mg} / \mathrm{mL}$ BSA, adjusted to $\mathrm{pH} 7.8$ with $\mathrm{KOH}$ ) were added. From this mixture, $50 \mu \mathrm{L}$ aliquots were added to the gel-embedded nucleoids containing high levels of BPDE-DNA adducts, and incubated for 10 minutes on a heating plate at $37^{\circ} \mathrm{C}$. Alkaline treatment and electrophoresis, each 20 minutes, were conducted as in the standard comet assay. The increase in DNA breaks at 10 minutes, leading to increased tail moments, is indicative for the NER capacity of the cell extracts. After subtracting background levels from all data, the final repair capacity was calculated according to Langie et al. [18]. 


\section{Chapter 4}

\section{Urine analysis}

Processing of urine samples for estimation of 8-oxodG levels was performed according to Dziaman et al. [24]. Briefly, $0.05 \mathrm{nmol}$ of $\left[{ }^{15} \mathrm{~N}_{5}\right]-8$-oxodG as internal standard and $10 \mu \mathrm{L}$ of acetic acid (Sigma, HPLC grade, concentration 99\%) were added to $2 \mathrm{~mL}$ of urine. After centrifugation ( $2000 \mathrm{x} \mathrm{g}, 10 \mathrm{~min}$ ), supernatant was filtered using a Millipore GV13 $0.22 \mu \mathrm{m}$ syringe filter and $500 \mu \mathrm{L}$ of this solution was injected into the HPLC system. Purification of 8-oxodG by HPLC was performed as described by Gackowski et al. [25]. GC/MS analysis was performed according to the method described by Dizdaroglu [26].

\section{Statistical analysis}

Results are presented as mean values \pm standard error. Differences in iron content, levels of oxidative damage, repair capacities, and urinary excretion were analyzed by T-tests. Relationships between various parameters were assessed by linear regression. Statistical analysis was performed using SPSS v.15.0. A P-value $\leq 0.05$ was considered statistically significant.

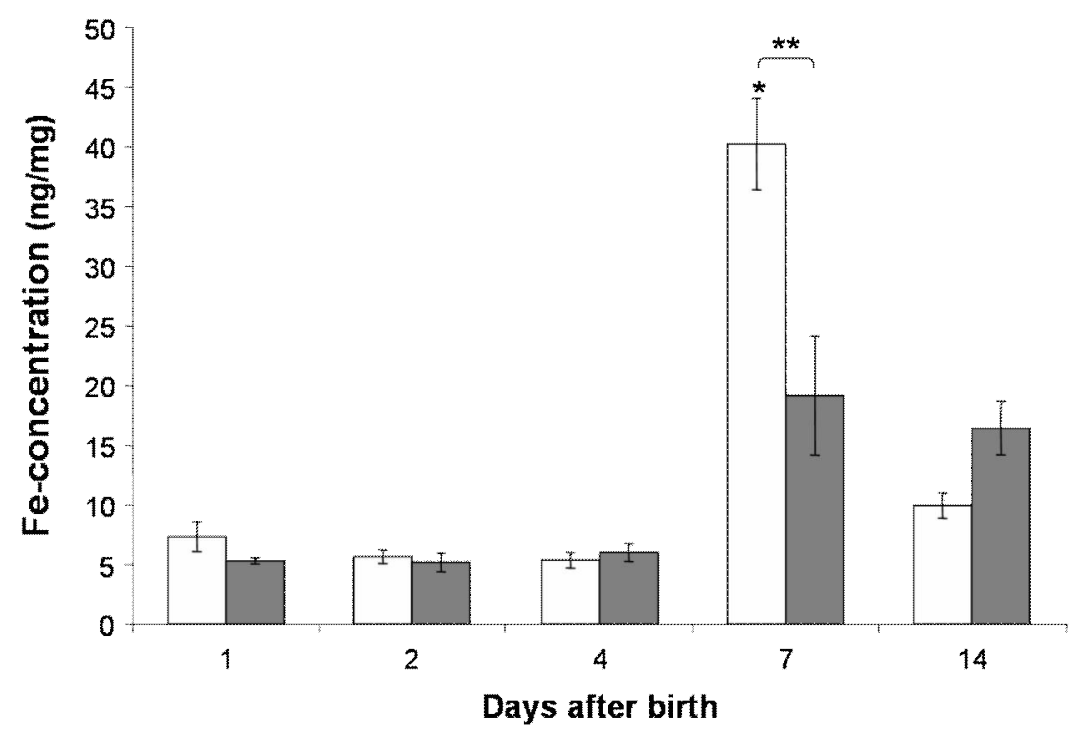

Figure 2. Iron concentrations in the colon of non-supplemented controls ( $\square$ ) and supplemented piglets $(\square)$. The level of iron in the colon tissues of the control group was significantly increased at day $7\left({ }^{*} \mathrm{P}=0.002\right)$. The supplementation of piglets resulted in a lower iron concentration in the colon tissues at day 7 as compared to the controls $\left({ }^{* *} \mathrm{P}=0.004\right)$. Data are presented as the mean values $(n=3-9)$ and bars indicate standard errors of the mean. 


\section{Results}

\section{Iron-induced oxidative stress in animal model}

The iron-induced oxidative stress was studied in the newborn piglets by assessment of; i) the iron content in colon tissue, ii) 8-oxodG levels in tissue and iii) urinary excretion of 8-oxodG. Upon injection of FeDex at day 3, the iron levels in the colon significantly increased at day $7(P<0.001)$ to 5 -times the initial level (Figure 2 , white bars). At day 14 after birth, the iron concentrations in the colon had decreased again to the initial background levels. 8-OxodG levels in colon were significantly $\sim 3$-fold increased at day 7 and 14 after birth and after iron treatment (Figure 3, white bars). These elevated levels of 8-oxodG correlated with the amount of iron in colon tissue $(R=0.477, P=0.010)$. Urinary excretion of 8-oxodG increased gradually upon FeDex exposure to significantly $\sim 3$-fold higher levels at day 14 compared to day 1 (Figure 4, white bars).

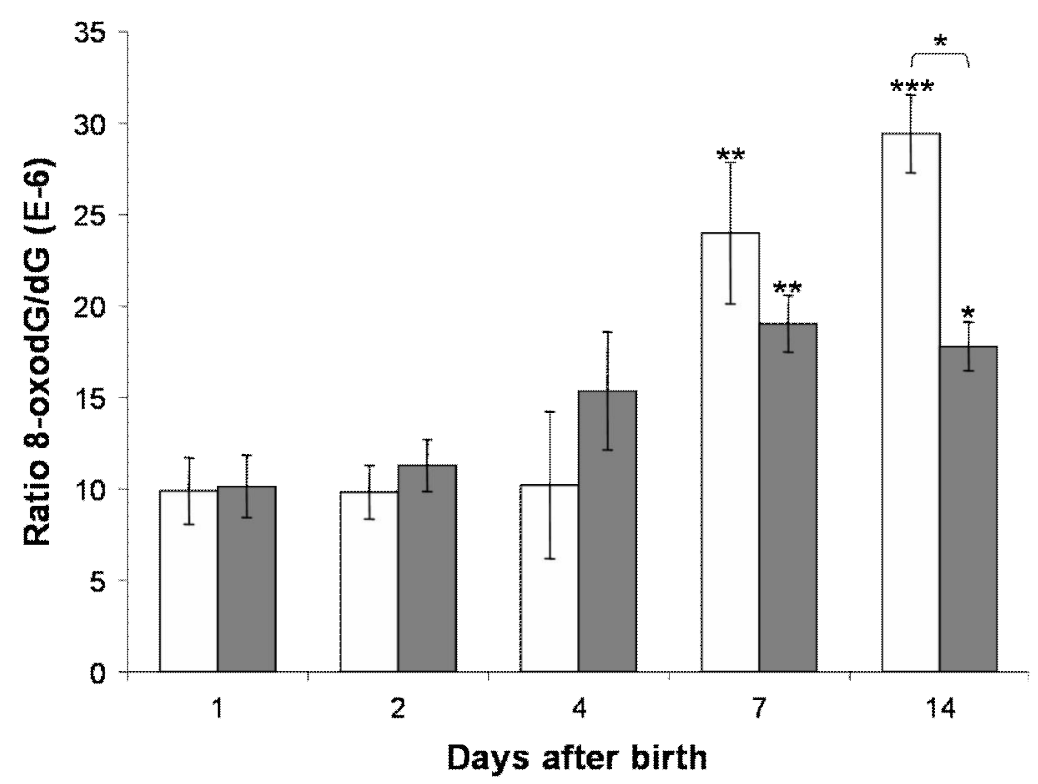

Figure 3. Levels of 8-oxodG in the colon tissues; from piglets not supplemented with antioxidant enriched diet $(\square)$, and from supplemented piglets $(\square)$. In both groups 8oxodG in the colon tissues was significantly increased at day 7 and 14 as compared to day 1 after birth $\left({ }^{* *} P=0.016\right.$, ${ }^{* * *} P=0.003$ for the controls, and ${ }^{* *} P=0.012,{ }^{*} P=0.050$ for the supplemented piglets, respectively). Moreover, supplementation significantly reduced the 8 -oxodG levels on day 14 ( ${ }^{*} \mathrm{P}=0.044$ supplemented vs. controls). Data are presented as the mean values ( \pm standard error). 


\section{Chapter 4}

\section{Antioxidant enriched dietary supplementation}

The intervention with antioxidant enriched diet was shown to be effective in reducing iron levels in the colon tissues of the supplemented piglets; $53 \%$ lower levels were observed at day 7 as compared to the controls (Figure 2, grey bars), which is expected to result in reduced levels of oxidative stress in the colon as well. Indeed, the level of 8-oxodG in colon of the supplemented group was significantly reduced to $60 \%$ at day 14 as compared to the unsupplemented group (Figure 3, grey bars). Moreover, Figure 4 shows that the increase in the urinary excretion of 8-oxodG occurred sooner and the removal was more efficient in the supplemented piglets (already $\sim 2$-fold increase at day 4 and $\sim 8$-fold at day 14 ) as compared to the controls ( 3 -fold increase at day 14 ).

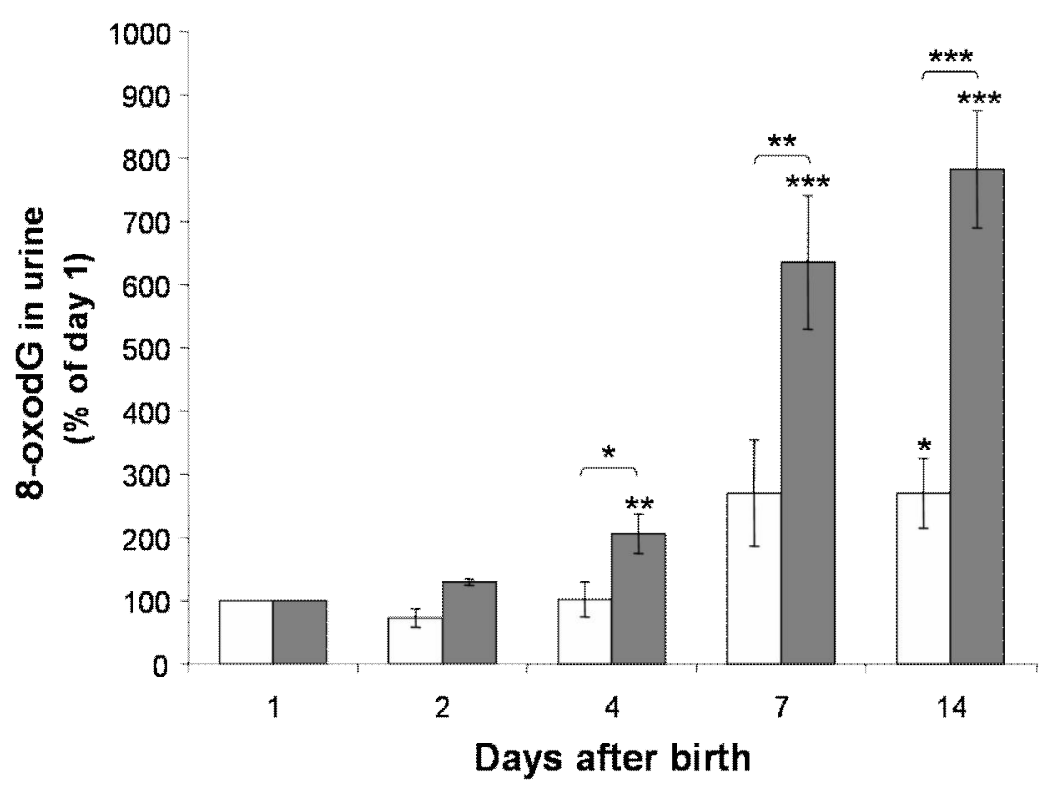

Figure 4. Urinary excretion rates of 8-oxodG in newborn piglets of the control $(\square)$ and supplemented $(\mathbf{\square})$ groups. Urinary 8-oxodG levels of the control group are significantly increased at day 14 versus day 1 , though, the supplemented piglets show significantly increased urine levels of 8-oxodG already at day 4 . Moreover, significant differences in 8-oxodG excretion between the supplemented group and the controls were observed from day 4 onwards. Mean data values are presented as percentages of day 1. Bars indicate standard error of the mean $\left({ }^{*} P=0.050,{ }^{* *} P<0.003,{ }^{* * *} P<0.005\right)$.

Furthermore, we noted that the initial excretions of 8-oxodG at day 1 were lower in the supplemented group than in the controls $(0.58 \pm 0.24 \mathrm{vs}$. $1.39 \pm 0.42$ respectively), which could be an effect of the supplementation of the mother sows during 
pregnancy. In case the urinary excretion data were calculated as percentages of day 1 , a significant difference in excretion of 8-oxodG was seen between the supplemented and non-supplemented newborn piglets. In the supplementation group, excretion of 8 -oxodG was significantly enhanced by $100 \%$ at day $4,365 \%$ at day 7 , and by $510 \%$ at day 14 as compared to the control group $(P=0.050, P=0.028$ and $P=0.003$, respectively).

\section{Effects of oxidative stress with and without antioxidant intervention on DNA repair}

First of all, it should be noted that the NER capacities at day 2 (prior to FeDex injection) were already decreased with ca. $20 \%$ in both the supplemented and control group. However, the subsequent iron-induced oxidative stress in the piglets was paralleled by a further decline of the NER capacity to $32 \%$ at day 7 as compared to day 1 after birth, which was partly restored to $54 \%$ at day 14 (Table II). Moreover, a significant inverse correlation of NER with the levels of $F e(R=-0.734$, $P=0.016)$ and the formation of 8 -oxodG in the colon were seen $(R=-0.701$, $P=0.024)$. A significant beneficial effect of the antioxidant supplementation on phenotypic NER capacity was seen at day 7 after birth (Table II, $P=0.050$ ), which was significantly less reduced by oxidative stress than in the group of unsupplemented animals (reduced to $69 \%$ in stead of $32 \%$, respectively).

Table II. Mean repair capacities in colon tissues of newborn piglets as calculated from tail moment values ( \pm standard errors) and as percentage of day 1 .

\begin{tabular}{rlcllc}
\hline \multirow{2}{*}{ Day } & \multicolumn{2}{c}{ NER (Arbitrary \pm SE) } & & \multicolumn{2}{c}{ NER (\% of day 1) } \\
\cline { 2 - 3 } \cline { 5 - 6 } \cline { 5 - 6 } & Controls & Supplemented & & Controls & Supplemented \\
\hline 1 & $1.55 \pm 1,34$ & $1.56 \pm 0.40$ & & 100.00 & 100.00 \\
2 & $1.19 \pm 0,67$ & $1.20 \pm 0.31$ & & 79.77 & 76.92 \\
4 & $0.96 \pm 1.39$ & $1.39 \pm 0.27$ & & 61.94 & 89.10 \\
7 & $0.50 \pm 0.11^{*}$ & $1.08 \pm 0.20^{*}$ & & $32.26^{*}$ & $69.23^{*}$ \\
14 & $0.84 \pm 0.31$ & $0.81 \pm 0.11$ & & 54.19 & 51.92 \\
\hline
\end{tabular}

* Significant difference in NER capacity between these groups $(P=0.050)$. 


\section{Discussion}

Ongoing research has focused on factors that can modulate the rate of DNA repair. Previous in vitro studies showed that increased oxidative stress can inhibit NER [8], which was confirmed in vivo in the current study. The modulation of oxidative stress by antioxidant rich diets could theoretically protect NER against a reduction in its activity and could thus improve the maintenance of genomic integrity. Indeed, in this study, supplementation of mother sows with an antioxidant enriched diet seemed to partly compensate the oxidative stress-induced reduction of the NER capacity in colon tissues of their newborn offspring.

Although the oxidative stress observed in the newborn piglets may partly be a consequence of a sudden increase in oxygenation after birth [24], the intramuscular injection of $200 \mathrm{mg}$ FeDex resulted in elevated amounts of iron in the colon and subsequently increased levels of 8-oxodG in colon DNA. Increased urinary excretion rates of 8-oxodG, as additional biomarker of oxidative stress upon injection with FeDex, confirms previous observations in rats [27]. This increase in oxidative stress was paralleled by a decline in NER capacity to $32 \%$ of the initial levels in newborn piglets (Table II). Although, it is not yet clear which factors contribute to this reduction of NER capacity, several factors that are released during oxidative stress have the ability to inhibit NER, such as lipid peroxidation products (e.g. 4hydroxynonenal, malondialdehyde), most likely by direct oxidative attack and inactivation of NER proteins [28-30].

We proposed that the inhibiting effects of oxidative stress on DNA repair could be compensated for by antioxidant supplementation. In the present study, the supplementation consisted of a blend of bioactive compounds (Table I). All of these compounds posses antioxidant activity, mainly by acting as scavengers of ROS and lipid peroxidation products [31-34]. Moreover, studies have shown that this antioxidant rich diet improved the development of intestinal mucosa in comparison to the commercial diets (with little antioxidants) used in the pig industry [19] and some of the dietary compounds (e.g. fibres, phytic acid and polyphenols) were found to bind pro-oxidant metals like iron resulting in decreased absorption by intestinal epithelial cells [35]. For instance, Glahn et al. showed that phytic acid and polyphenols inhibited iron uptake by the colon cell line, Caco-2 [36]. Furthermore, Grinberg et al. reported that the iron binding capacity of polyphenols accounted for most of its protective effect against oxidative stress [37]. These observations are in correspondence with the lower levels of total iron in colon tissue and a lower amount of 8-oxodG in the colon DNA from offspring of antioxidant supplemented sows as shown in the current study. Some studies have also reported significant effects of these dietary factors on the levels of 8-oxodG in cellular DNA [38-41], but it should be mentioned that this could not be reproduced by others [31,38,42].

As hypothesised, nucleotide excision repair capacities were beneficially affected by the supplementation with the blend of bioactive compounds. Although the repair capacity still decreased in time after birth and iron administration, this reduction was 
significantly smaller as compared to animals that were not supplemented. Until now, a small number of studies has assessed the influence of diet and dietary compounds on DNA repair processes .[43,44]. One study in particular showed an increased BER capacity in human lymphocytes upon supplementation with kiwifruits in vivo [45].

In the present study, lower levels of 8-oxodG in colon tissues of supplemented piglets was linked with enhanced urinary excretion of 8-oxodG as compared to the control group. The levels of 8 -oxodG in cellular DNA represent a dynamic equilibrium between rates of oxidative DNA damage and rates of repair of the damage. Therefore, the excretion rate (which most likely represents repair processes) combined with determination of 8-oxodG in cellular DNA may resolve the basic issue concerning the possible link of rates of repair versus rates of damage. As a matter of fact, only comparison of these two parameters can give information about the meaning of oxidative DNA damage excreted in urine. For example, an agent like $\mathrm{Fe}$ is responsible for increases of oxidative stress and as a consequence increased 8-oxodG levels in cellular DNA and in urine. In the above mentioned animal groups, a simultaneous increase of urinary 8-oxodG levels was observed as possible repair products. Moreover, the dietary intervention decreased the level of 8-oxodG in tissue, but increased urinary excretion of 8-oxodG. This strongly suggests that the diet might in fact be profitable stimulating DNA repair and therefore decreasing background cellular levels of 8-oxodG. On basis of these observations, one could argue that the lower levels of 8-oxodG in the colon tissues in the supplemented group are the direct result of improved NER capacities. Indeed, it has been suggested that the NER pathway is involved in the repair of oxidized bases [46-48], though, additional DNA repair routes, like elimination of 8-oxodGMP by Nudix hydrolases from the nucleotide pools, are important contributors to the presence of oxidatively modified 2'-deoxyribonucleosides in urine [49-51]. It is not possible to distinguish cause and effect in the present study. Therefore, our data rather suggest that the formation of 8-oxodG in the colon is merely an indicator of increased oxidative stress, which subsequently inhibits DNA repair, also because NER capacity and the levels of $\mathrm{Fe}$, as an inducer of oxidative stress, are inversely correlated $(\mathrm{R}=-0.734, \mathrm{P}=0.016)$.

Collectively, our data demonstrate that oxidative stress may inhibit nucleotide excision repair in vivo. These deleterious effects can be compensated for by an antioxidant enriched diet. Although, the underlying mechanisms remain unclear, a reduction in repair capacity during diseases that involve oxidative stress might contribute to mutagenesis and carcinogenesis. Dietary interventions could guard against these effects by protecting the DNA repair processes that maintain the integrity of the DNA. As such, considering the prominent role of DNA damage and repair in health and disease, further research on the modulation of DNA repair is urgently needed. 


\section{Chapter 4}

\section{Acknowledgments}

This work was financed by the Polish Ministry of Science and Higher Education grant (PBZ-KBN-093/P06/2003). Part of the studies was supported by the European Network of Excellence (NoE) "Environmental Cancer risk, Nutrition and Individual Susceptibility" (ECNIS), operating within European Union sixth Framework Programme (FP6), Priority 5: "Food Quality and Safety", FOOD-CT-2005-513943.

\section{References}

1. Ames B. N. Endogenous oxidative DNA damage, aging, and cancer. Free Radic Res Commun 1989;7:121-128.

2. Cooke M. S., Evans M. D., Dizdaroglu M. and Lunec J. Oxidative DNA damage: mechanisms, mutation, and disease. Faseb J 2003;17:1195-1214.

3. Floyd R. A. Role of oxygen free radicals in carcinogenesis and brain ischemia. Faseb J 1990;4:2587-2597.

4. Jaiswal M., LaRusso N. F., Nishioka N., Nakabeppu Y. and Gores G. J. Human Ogg1, a protein involved in the repair of 8-oxoguanine, is inhibited by nitric oxide. Cancer Res 2001;61:6388-6393.

5. Graziewicz M., Wink D. A. and Laval F. Nitric oxide inhibits DNA ligase activity: potential mechanisms for NO-mediated DNA damage. Carcinogenesis 1996;17:2501-2505.

6. Wink D. A. and Laval J. The Fpg protein, a DNA repair enzyme, is inhibited by the biomediator nitric oxide in vitro and in vivo. Carcinogenesis 1994;15:2125-2129.

7. Laval F. and Wink D. A. Inhibition by nitric oxide of the repair protein, O6methylguanine-DNA-methyltransferase. Carcinogenesis 1994;15:443-447.

8. Langie S. A., Knaapen A. M., Houben J. M., van Kempen F. C., de Hoon J. P., Gottschalk R. W., Godschalk R. W. and van Schooten F. J. The role of glutathione in the regulation of nucleotide excision repair during oxidative stress. Toxicol Lett 2007;168:302-309.

9. Foksinski M., Rozalski R., Guz J., Ruszkowska B., Sztukowska P., Piwowarski M., Klungland $A$. and Olinski $R$. Urinary excretion of DNA repair products correlates with metabolic rates as well as with maximum life spans of different mammalian species. Free Radic Biol Med 2004;37:1449-1454.

10. Andersson L., Haley C. S., Ellegren H., Knott S. A., Johansson M., Andersson K., Andersson-Eklund L., Edfors-Lilja I., Fredholm M., Hansson I. and et al. Genetic mapping of quantitative trait loci for growth and fatness in pigs. Science 1994;263:1771-1774.

11. Asikainen T. M., Raivio K. O., Saksela M. and Kinnula V. L. Expression and developmental profile of antioxidant enzymes in human lung and liver. Am J Respir Cell Mol Biol 1998;19:942-949.

12. Gerdin E., Tyden O. and Eriksson U. J. The development of antioxidant enzymatic defense in the perinatal rat lung: activities of superoxide dismutase, glutathione peroxidase, and catalase. Pediatr Res 1985;19:687-691.

13. Seril D. N., Liao J., Yang G. Y. and Yang C. S. Oxidative stress and ulcerative colitis-associated carcinogenesis: studies in humans and animal models. Carcinogenesis 2003;24:353-362.

14. Nouveaux cas de cancer au Luxembourg - Monographies des années 1983 - 1984 - 1994 - 1995 - 1996 - 1997 - 1998. Luxembourg: Registre Morphologique des Tumeurs au Grand-Duché de Luxembourg; 1997.

15. Howe H. L., Wingo P. A., Thun M. J., Ries L. A., Rosenberg H. M., Feigal E. G. and Edwards B. K. Annual report to the nation on the status of cancer (1973 through 
1998), featuring cancers with recent increasing trends. J Natl Cancer Inst 2001;93:824-842.

16. Cancer Facts and Figures 2005. Atlanta, GA: American Cancer Society; 2005.

17. Meneghini R. Iron homeostasis, oxidative stress, and DNA damage. Free Radic Biol Med 1997;23:783-792.

18. Langie S. A., Knaapen A. M., Brauers K. J., van Berlo D., van Schooten F. J. and Godschalk R. W. Development and validation of a modified comet assay to phenotypically assess nucleotide excision repair. Mutagenesis 2006;21:153-158.

19. Zabielski R Gajewski Z, Valverde Pietra JL, Laubitz D, Wilczak J, Bałasińska B, Kulasek G. The perinatal development of the gastrointestinal tract in piglets can be modified by supplementation of sow diet with bioactive substances. Livestock Science 2007;109:34-37.

20. Puzio I Kapica M, Bieńko M, Valverde Piedra JL, Gajewski Z, Kulasek G, Zabielski R. Dietary bioactive substances influenced perinatal bone development in piglets. Livestock Science 2007;108:72-75.

21. Godschalk R. W., Maas L. M., Van Zandwijk N., van 't Veer L. J., Breedijk A., Borm P. J., Verhaert J., Kleinjans J. C. and van Schooten F. J. Differences in aromaticDNA adduct levels between alveolar macrophages and subpopulations of white blood cells from smokers. Carcinogenesis 1998;19:819-825.

22. ESCODD Comparison of different methods of measuring 8-oxoguanine as a marker of oxidative DNA damage. Free Radic Res 2000;32:333-341.

23. de Kok T. M., ten Vaarwerk F., Zwingman I., van Maanen J. M. and Kleinjans J. C. Peroxidation of linoleic, arachidonic and oleic acid in relation to the induction of oxidative DNA damage and cytogenetic effects. Carcinogenesis 1994;15:13991404.

24. Dziaman T., Gackowski D., Rozalski R., Siomek A., Szulczynski J., Zabielski R. and Olinski R. Urinary excretion rates of 8-oxoGua and 8-oxodG and antioxidant vitamins level as a measure of oxidative status in healthy, full-term newborns. Free Radic Res 2007;41:997-1004.

25. Gackowski D., Rozalski R., Roszkowski K., Jawien A., Foksinski M. and Olinski R. 8-Oxo-7,8-dihydroguanine and 8-oxo-7,8-dihydro-2'-deoxyguanosine levels in human urine do not depend on diet. Free Radic Res 2001;35:825-832.

26. Dizdaroglu M. Chemical determination of oxidative DNA damage by gas chromatography-mass spectrometry. Methods Enzymol 1994;234:3-16.

27. Wellejus A., Poulsen H. E. and Loft S. Iron-induced oxidative DNA damage in rat sperm cells in vivo and in vitro. Free Radic Res 2000;32:75-83.

28. Feng Z., Hu W. and Tang M. S. Trans-4-hydroxy-2-nonenal inhibits nucleotide excision repair in human cells: a possible mechanism for lipid peroxidation-induced carcinogenesis. Proc Natl Acad Sci U S A 2004;101:8598-8602.

29. Hiramatsu K., Ogino T., Ozaki M. and Okada S. Monochloramine inhibits ultraviolet B-induced p53 activation and DNA repair response in human fibroblasts. Biochim Biophys Acta 2006;1763:188-196.

30. Feng Z., Hu W., Marnett L. J. and Tang M. S. Malondialdehyde, a major endogenous lipid peroxidation product, sensitizes human cells to UV- and BPDEinduced killing and mutagenesis through inhibition of nucleotide excision repair. Mutat Res 2006;601:125-136.

31. Hwang E. S. and Bowen P. E. DNA damage, a biomarker of carcinogenesis: its measurement and modulation by diet and environment. Crit Rev Food Sci Nutr 2007;47:27-50.

32. Bouckenooghe T., Remacle C. and Reusens B. Is taurine a functional nutrient? Curr Opin Clin Nutr Metab Care 2006;9:728-733.

33. Dong M. H. and Kaunitz J. D. Gastroduodenal mucosal defense. Curr Opin Gastroenterol 2006;22:599-606. 
34. Lee J. C., Bhora F., Sun J., Cheng G., Arguiri E., Solomides C. C., Chatterjee S. and Christofidou-Solomidou M. Dietary flaxseed enhances antioxidant defenses and is protective in a mouse model of lung ischemia-reperfusion injury. Am J Physiol Lung Cell Mol Physiol 2008;294:L255-265.

35. Lopez M. A. and Martos F. C. Iron availability: An updated review. Int J Food Sci Nutr 2004;55:597-606.

36. Glahn R. P., Wortley G. M., South P. K. and Miller D. D. Inhibition of iron uptake by phytic acid, tannic acid, and $\mathrm{ZnCl} 2$ : studies using an in vitro digestion/Caco-2 cell model. J Agric Food Chem 2002;50:390-395.

37. Grinberg L. N., Newmark H., Kitrossky N., Rahamim E., Chevion M. and Rachmilewitz E. A. Protective effects of tea polyphenols against oxidative damage to red blood cells. Biochem Pharmacol 1997;54:973-978.

38. Moller P. and Loft S. Dietary antioxidants and beneficial effect on oxidatively damaged DNA. Free Radic Biol Med 2006;41:388-415.

39. Messina S. A. and Dawson R., Jr. Attenuation of oxidative damage to DNA by taurine and taurine analogs. Adv Exp Med Biol 2000;483:355-367.

40. Morin B., Narbonne J. F., Ribera D., Badouard C. and Ravanat J. L. Effect of dietary fat-soluble vitamins $A$ and $E$ and proanthocyanidin-rich extract from grape seeds on oxidative DNA damage in rats. Food Chem Toxicol 2008;46:787-796.

41. Miyazaki T., Karube M., Matsuzaki Y., Ikegami T., Doy M., Tanaka N. and Bouscarel B. Taurine inhibits oxidative damage and prevents fibrosis in carbon tetrachloride-induced hepatic fibrosis. $J$ Hepatol 2005;43:117-125.

42. Eder E., Wacker M., Lutz U., Nair J., Fang X., Bartsch H., Beland F. A., Schlatter J. and Lutz W. K. Oxidative stress related DNA adducts in the liver of female rats fed with sunflower-, rapeseed-, olive- or coconut oil supplemented diets. Chem Biol Interact 2006;159:81-89.

43. Mathers J. C., Coxhead J. M. and Tyson J. Nutrition and DNA repair--potential molecular mechanisms of action. Curr Cancer Drug Targets 2007;7:425-431.

44. Tyson J. and Mathers J. C. Dietary and genetic modulation of DNA repair in healthy human adults. Proc Nutr Soc 2007;66:42-51.

45. Collins A. R., Harrington V., Drew J. and Melvin R. Nutritional modulation of DNA repair in a human intervention study. Carcinogenesis 2003;24:511-515.

46. Reardon J. T., Bessho T., Kung H. C., Bolton P. H. and Sancar A. In vitro repair of oxidative DNA damage by human nucleotide excision repair system: possible explanation for neurodegeneration in xeroderma pigmentosum patients. Proc Natl Acad Sci U S A 1997;94:9463-9468.

47. Dusinska M., Dzupinkova Z., Wsolova L., Harrington V. and Collins A. R. Possible involvement of XPA in repair of oxidative DNA damage deduced from analysis of damage, repair and genotype in a human population study. Mutagenesis 2006;21:205-211.

48. D'Errico M., Parlanti E., Teson M., de Jesus B. M., Degan P., Calcagnile A., Jaruga P., Bjoras M., Crescenzi M., Pedrini A. M., Egly J. M., Zambruno G., Stefanini M., Dizdaroglu M. and Dogliotti E. New functions of XPC in the protection of human skin cells from oxidative damage. Embo J 2006;25:4305-4315.

49. Cooke M. S. and Evans M. D. 8-Oxo-deoxyguanosine: reduce, reuse, recycle? Proc Natl Acad Sci U S A 2007;104:13535-13536.

50. Cooke M. S., Evans M. D., Dove R., Rozalski R., Gackowski D., Siomek A., Lunec $\mathrm{J}$. and Olinski R. DNA repair is responsible for the presence of oxidatively damaged DNA lesions in urine. Mutat Res 2005;574:58-66.

51. Cooke M. S., Olinski R. and Loft S. Measurement and meaning of oxidatively modified DNA lesions in urine. Cancer Epidemiol Biomarkers Prev 2008;17:3-14. 




\section{Chapter 5}

\section{Modulation of the nucleotide excision repair capacity in human lymphocytes by genetic and dietary factors}

Submitted

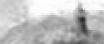




\section{Chapter 5}

\section{Abstract}

Gene-environment interactions determine inter-individual variations in nucleotide excision repair (NER) capacity. Oxidative stress was previously found to inhibit NER, thus supplementation with dietary antioxidants could prevent NER to be reduced by oxidative stress, especially in genetically susceptible subjects. Therefore, to study the effects of genetic polymorphisms in NER-related genes and dietary intake of antioxidants on an individual's DNA repair capacity (DRC), lymphocytes of 168 subjects were isolated before and after a four week intervention with an antioxidant rich blueberry/apple juice. A total of 11 genetic polymorphisms in the NER genes XPA, XPB, XPC, XPD, ERCC1, ERCC5, ERCC6 and RAD23B was assessed by multiplex PCR with single base extension. On the basis of genotypecombinations, a subset of individuals $(n=36)$ was selected for phenotypically assessing NER capacities, which appeared to be significantly affected by the XPAA23G polymorphism ( $P=0.002)$; XPA-AA carriers having $\sim 3$-fold lower $D R C$ than XPA-GG carriers. NER capacities assessed before and after the dietary intervention correlated significantly $\left(R^{2}=0.71, P<0.001\right.$, slope=0.95), indicating that interindividual differences in DRC are maintained over a 4 week period. Although the blueberry/apple juice intervention improved antioxidant status, on average it did not affect NER capacities. Nonetheless, carriers of at least one variant allele for XPC$\mathrm{K} 939 \mathrm{Q}$ or $R A D 23 B-\mathrm{A} 249 \mathrm{~V}$ did benefit from the intervention, showing improved NER after the intervention compared to homozygous wild-types. However, these dietary effects on NER capacity did not outweigh the impact of the XPA-genotype. In conclusion, the XPA-A23G polymorphism was the predominant predictor for NER capacity. 


\section{Introduction}

Molecular epidemiological studies have reported large inter-individual variations in susceptibility to environmental carcinogens and subsequent cancer risk, which may partly be due to genetically determined variations in DNA repair capacity (DRC) [1-4]. One particular DNA repair mechanism, the nucleotide excision repair (NER) pathway, protects the integrity of the genome by recognizing and eliminating a broad spectrum of bulky lesions like UV-induced pyrimidine dimers, aromatic DNA adducts, crosslinks, and several types of oxidative damage [5]. NER is a versatile DNA repair system involving the joint action of a variety of enzymes like XPC-RAD23B, CSB, XPA, XPFERCC1, and others [6,7]. It is clear that NER plays a crucial role in cancer prevention, because defects in this pathway lead to several severe human disorders [8]. Furthermore, several studies suggest that genetic polymorphisms in various NER genes may have a profound impact on the phenotypical activity of this repair pathway. For instance, Zhu et al. showed that single nucleotide polymorphisms (SNPs) in coding and regulatory regions of $X P C$ can alter both gene expression and enzyme activity (11); the $\mathrm{K939Q}$ variant allele of $X P C$ resulted in reduced $\mathrm{DRC}$, whereas another variant allele of XPC (A499V) increased DRC [9]. The common polymorphism $23 A \rightarrow G$, situated in the $5^{\prime}$ untranslated region (5'-UTR) of XPA, was associated with more efficient DRC [10]. Dušinská et al. indeed found a significant association between the XPA-AA genotype and elevated levels of 8-oxoguanine in lymphocyte DNA [11]. In addition, several genetic polymorphisms in DNA repair genes were shown to modulate the levels of bulky-DNA adducts $[9,12,13]$ or chromosomal damage [14-16]. So, several studies identified associations between polymorphisms in DNA repair genes with the amount of DNA damage and the capacity to repair these damages.

Next to the effect of SNPs on DNA repair activity, other factors, like diet should also be taken into account. Although there is sufficient evidence for chemopreventive effects of certain dietary compounds [17], only a few studies have reported that dietary compounds influence DNA repair processes (reviewed by Tyson and Mathers [18]). In fact, to the best of our knowledge, there is only one study that investigated the effect of dietary factors on NER, observing an association between low dietary folate intake and reduced DRC [19]. As such, there is an increasing need to study the impact of diet on NER activity.

We previously showed that especially oxidative stress can inhibit NER activity $[20,21]$. Thus, enhanced dietary intake of antioxidants may represent an opportunity for improving NER by reducing oxidative stress. Therefore, we studied the dietary modulation of DNA repair by using samples from a four-week intervention study with healthy volunteers, consuming $1 \mathrm{~L}$ of blueberry/apple juice per day [22]. This intervention was found to be efficient in enhancing antioxidant defence and reducing the levels of ex vivo induced oxidative DNA damage [22,23]. In the current study, our aim was to investigate the effect of this intervention as well as the effect of genetic polymorphisms in NER genes on the phenotypic NER capacity as assessed by a modified alkaline comet assay, which was recently developed at our laboratory [24]. 


\section{Chapter 5}

\section{Materials and Methods}

\section{Study population}

The study population consisted of 168 healthy volunteers, 114 female and 54 male, aged 18-45 years (for more details see references [22,23]). Volunteers were recruited through advertisement in local newspapers and were included if they were non-smokers, did not use any medication (except for oral contraceptives) or any vitamin supplementation. Subjects were informed about the details of the study and gave their written informed consent. The protocol was approved by the Medical Ethical Committee of Maastricht University and the Academic Hospital Maastricht.

\section{Dietary intervention}

Since we were particularly interested in raising plasma antioxidant levels by the intervention, volunteers were given a list of food ingredients rich in antioxidants, which they had to avoid during a 5-day washout period. The food items on this list were described in a previous study [22]. The design of this intervention as well as the efficacy of the washout period was based on a pilot study, described earlier [23]. Each subject acted as his/ her own control. The 5-day washout period was followed by a 4-week intervention period with a custom-made blueberry/apple juice mixture, produced specifically for this study by Riedel Drinks (Riedel, Ede, The Netherlands), of which subjects consumed $1 \mathrm{~L} /$ day. This blueberry/ apple juice mixture contained high levels of antioxidants, predominantly in the form of flavonoids. Supplementation with this juice for 4 weeks was reported to be effective, as the intervention significantly increased plasma antioxidant concentrations and total plasma antioxidant capacity [22]. The impact of seasonal variation in dietary habits or increased sensitivity was overcome by year-round random sampling.

\section{Collection of samples}

After the 5-day washout period, the first blood sample was obtained between 8 and 9 AM by venapuncture. Volunteers were allowed to have breakfast before sampling. After the 4-week intervention period, the second blood sample was also drawn between 8 and 9 AM. Again, breakfast was allowed but no juice. Venous blood samples were obtained into one $10 \mathrm{~mL}$ EDTA vacuum tube for plasma analyses and into two $10 \mathrm{~mL}$ vacuum lithium heparin tubes (venoject II, Terumo-Europe, Leuren, Belgium) for isolation of lymphocytes. The EDTA tubes were centrifuged for $10 \mathrm{~min}$ at $265 \mathrm{~g}$ at $4^{\circ} \mathrm{C}$ to separate plasma for the analysis of the trolox equivalent antioxidant capacity (TEAC value) and determination of antioxidant concentrations as described previously [22]. All plasma samples were kept at $-80^{\circ} \mathrm{C}$ until analysis. Lymphocytes were isolated from heparinized venous blood of human volunteers using a standard density gradient centrifugation method [25], aliquoted and stored as cell pellets at $-20^{\circ} \mathrm{C}$. One aliquot was used to isolate DNA for genotyping 
purposes, using standard phenol extraction procedures. Another lymphocyte aliquot was used to prepare extracts to phenotypically assess NER capacity.

\section{Selection of Polymorphisms}

In this study, single nucleotide polymorphisms (SNPs) in NER genes (Table I) were selected on the basis of (a) their association with cancer development; or (b) their expected influence on DNA repair based on literature review, as shown in Table II. DNA sequences and allele frequencies were obtained from the Cancer SNP 500 database (http://snp500cancer.nci.nih.gov).

\section{PCR Primer Design and Multiplex PCR Amplification}

Primer 3 software (http://www.broad.mit.edu/cgi-bin/primer/primer3_www.cgi) and (http://www.premierbiosoft.com/netprimer/netprlaunch/netprlaunch.html) Netprimer software were used to design PCR primers [see Knaapen et al. [26] for more detailed information]. Primers were obtained from Qiagen. First, the isolated DNA containing SNPs was amplified in one nineplex and one duplex PCR reaction. For the nineplex PCR, a $10 \mu \mathrm{L}$ reaction mixture was prepared containing PCR buffer, 10 $\mathrm{mM}$ deoxynucleotide triphosphates, $50 \mathrm{mM} \mathrm{MgCl}_{2}, 5 \mathrm{U} / \mu \mathrm{L}$ of Platinum ${ }^{\circledR}$ Taq Polymerase (Invitrogen), and $40 \mathrm{ng} / \mathrm{\mu L}$ of template DNA. The final primer concentrations were $2.0 \mu \mathrm{M}$ (for XPC-03, ERCC6-01, ERCC1-05, ERCC1-06 and ERCC1-30), $0.8 \mu \mathrm{M}$ (for XPA-02), $1.2 \mu \mathrm{M}$ (for XPB), 1.6 $\mu \mathrm{M}$ (for XPC-01) and 4.0 $\mu \mathrm{M}$ (for Rad23B-04). For the duplex PCR, the final primer concentrations were 2.7 $\mu \mathrm{M}$ (for XPD-02) and 12.3 $\mu \mathrm{M}$ (for ERCC5-01) [see Table I for corresponding rsnumbers]. PCR was conducted as follows: denaturation at $94{ }^{\circ} \mathrm{C}$ for $3 \mathrm{~min} ; 30$ cycles of $94^{\circ} \mathrm{C}$ for $30 \mathrm{sec}, 63^{\circ} \mathrm{C}$ for $30 \mathrm{sec}$, and $72^{\circ} \mathrm{C}$ for $30 \mathrm{sec}$; and a final extension at $72^{\circ} \mathrm{C}$ for $5 \mathrm{~min}$. After PCR amplification, the products were pooled (5 $\mu \mathrm{L}$ of the nineplex and $3 \mu \mathrm{L}$ of the duplex PCR product) and incubated ( $37^{\circ} \mathrm{C}$ for 45 min) with $4 \mu \mathrm{L}$ of ExoSAP-IT (Amersham, Roosendaal, The Netherlands) to digest residual deoxynucleotide triphosphates and primers. Enzymes were deactivated at $75^{\circ} \mathrm{C}(15 \mathrm{~min})$

\section{Multiplex Genotyping}

Genotyping was performed by single base extension (SBE) using SnaPShot ${ }^{\mathrm{TM}}$ as described by the manufacturer (Applied Biosystems, Nieuwekerk a.d. IJssel, the Netherlands), with some modifications. Briefly, SBE primers were designed using Primer 3 and Netprimer software to bind immediately adjacent 5 ' to the specific SNP, with a template specific part of 20 to $33 \mathrm{bp}$ and a $\mathrm{Tm}$ of $66^{\circ} \mathrm{C}$ to $69^{\circ} \mathrm{C}$ (Table I). To facilitate detection of eleven polymorphisms in one single run, the length of the extension primers was adjusted to a distinct size by addition of a nonhomologous tail to their 5' site [26]. To this end, $5.5 \mu \mathrm{L}$ of the purified PCR product (containing eleven fragments) was mixed with $2.5 \mu \mathrm{L}$ of SNaPshot reaction mixture, $1 \mu \mathrm{L}$ of pooled SBE primers, and $1 \mu \mathrm{L}$ of water. The final concentration for all 


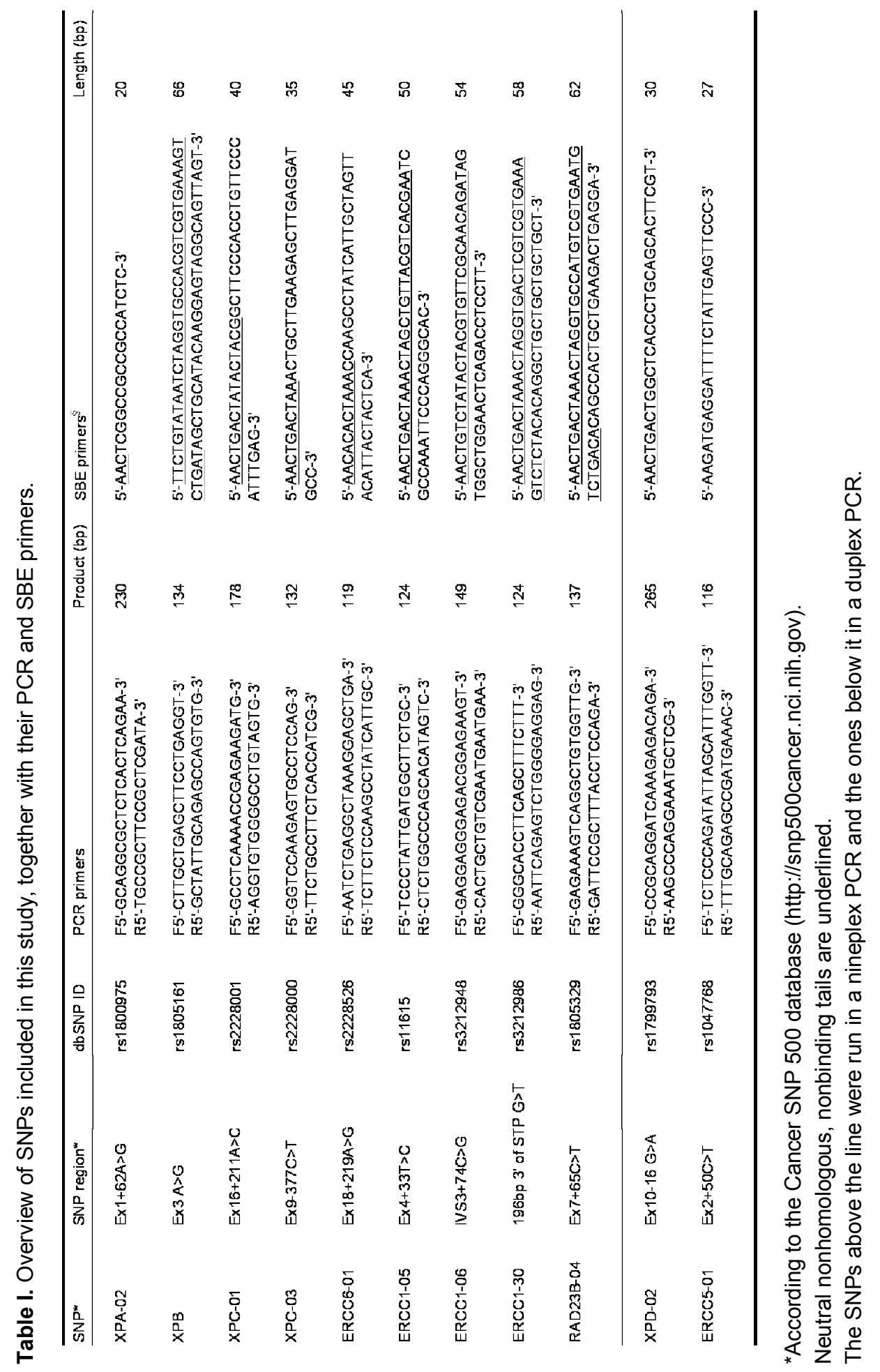




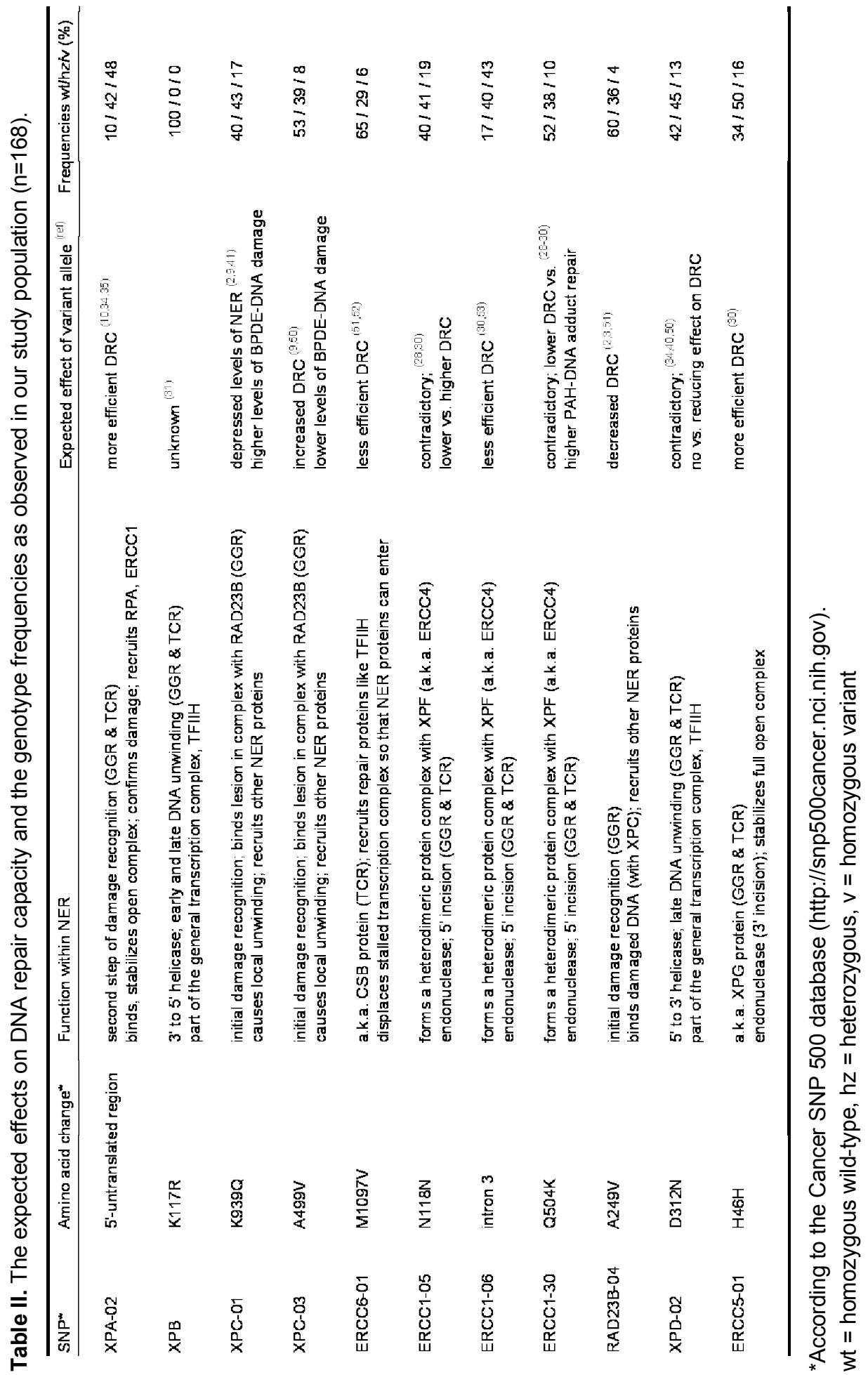




\section{Chapter 5}

SBE primers was $4 \mu \mathrm{M}$, except for XPA-02, ERCC5-01 and XPB (2 $\mu \mathrm{M})$. SBE was performed using 25 cycles of $96^{\circ} \mathrm{C}$ for $10 \mathrm{sec}$ and $60^{\circ} \mathrm{C}$ for $30 \mathrm{sec}$. Subsequently, the samples were incubated at $37^{\circ} \mathrm{C}$ for $1 \mathrm{~h}$ with $1 \mathrm{U}$ of shrimp alkaline phosphatase (Amersham), followed by enzyme deactivation at $75^{\circ} \mathrm{C}$ for $15 \mathrm{~min}$. The SBE products were finally analyzed by capillary electrophoresis, for which $1 \mu \mathrm{L}$ of the (fivefold-diluted) SBE product was mixed with $13 \mu \mathrm{L}$ of deionized formamide and 0.4 $\mu \mathrm{L}$ of Genescan-120 LIZTM size marker. Samples were denatured at $95{ }^{\circ} \mathrm{C}$ for 5 min and run on an ABI-Prism ${ }^{\circledR} 3100$ genetic analyzer using a 36-cm capillary array and POP-6 polymer. Analyses were performed with GenescanTM software (version. $3.7 ;[26])$.

\section{Measurement of NER capacity}

A subpopulation of 36 healthy volunteers, 28 female and 8 male, aged 18-45 years, was selected for the phenotypical assessment of NER. Since we previously observed that ERCC1 expression can be a proxy for NER capacity [20], selection of subjects occurred according to their ERCC1 genotype. More specifically, samples from homozygous wild-types and homozygous carriers of the variant allele for the three studied SNPs in ERCC1 were predominantly selected for DNA repair analysis. Power calculations based on an $\alpha$ of 0.05 , a minimal group size of 4 and taking into account the variation in $\mathrm{DRC}$, indicated that it will be possible to find a statistically significant 2 fold difference with a power of $>80 \%$.

To phenotypically assess the NER capacity in human lymphocytes, we applied a modified comet assay recently developed in our laboratory [24]. Basically, this assay measures the ability of a cell/tissue extract to incise substrate DNA containing benzo[a]pyrene-diolepoxide (BPDE)-DNA adducts. Thus, this assay reflects an individual's capacity to recognize and incise damaged DNA, which are important first steps in the NER process. The increase in DNA incisions/breaks, leading to increased tail moments, is indicative for the NER capacity of the cell extracts. After subtracting background levels from all data, the final repair capacity was calculated according to Langie et al. [24].

\section{Statistical analysis}

Differences in DNA repair capacities and TEAC before and after the intervention were analyzed by paired T-tests. To investigate the effect of the total number of lowactivity alleles on the NER capacity, genotypic polymorphisms were coded as number of low-activity alleles, based on literature and their expected modulating effect on the DRC (Table II); 0 (homozygous for high-activity allele), 1 (heterozygous; carrying one high- and one low-activity allele), and 2 (homozygous for low-activity allele) [similar approach as previously reported by Ketelslegers et al. [27]]. Subsequently, the total sum of low-activity alleles was computed and related to NER capacity. Stepwise multivariate, linear regression was used to asses the impact of sex, age, TEAC and various polymorphisms on the phenotypically assessed NER capacity. The 
relationship between NER capacity before and after intervention was assessed by linear regression. Statistical analysis was performed using SPSS v.15.0. In each case, a $\mathrm{P}$-value $\leq 0.05$ was considered statistically significant.

\section{Results}

\section{SNPs and Genotype frequencies}

In Table II, all analysed SNPs, amino acid changes related to the polymorphism, function of the proteins in NER and the expected effect of the variant allele on the DRC are listed. Furthermore, the frequencies of the wild-type, heterozygous and variant alleles as observed in our study population $(n=168)$ are represented and appear to be in Hardy-Weinberg equilibrium.

\section{Effects of genetic factors on the NER capacity}

As a first approach to investigate the influence of the genetic profile on the phenotypic DRC, the total sum of putative low-activity alleles was calculated and related to the NER capacities assessed before the dietary intervention. A significant inverse correlation between the amount of low-activity alleles and the NER capacities was observed (Figure $1 ; \mathrm{R}^{2}=0.68, \mathrm{P}=0.044$ ).

The impact of all genetic polymorphisms individually, as well as age and sex on $\mathrm{DRC}$ was assessed by stepwise regression analysis. Sex and age had no effect on NER. XPA-A23G ( $P=0.005)$ and XPC-K939Q $(P=0.050)$ revealed to be significant predictors of the NER capacity (Figure $2 \mathrm{~A}$ and $\mathrm{B}$ ) before the intervention. Individuals that were homozygous for the variant allele of XPA-A23G $(n=17)$ showed a 2.4 fold higher NER capacity as compared to those carrying the homozygous wildtype alleles $(n=5)$. Individuals carrying at least one variant allele of $X P C-K 939 Q$ $(n=16)$ had a $\sim 2$-fold lower NER capacity than carriers of the homozygous wild-type genotype $(n=20)$. The influence of the sum of low-activity alleles of both XPA-A23G and XPC-K939Q on the NER capacity before the intervention is shown in Figure 2C $(P<0.001)$; individuals having one or more low-activity alleles for these two genes $(n=24)$ showed a reduction of the NER capacity to $35 \%$ as compared to individuals carrying no such low-activity alleles $(n=12)$. When analysing samples of the same individuals from after the intervention, the association between the XPC-K939Q variant allele and NER capacity disappeared, suggesting that this association was affected by gene-diet interactions. The SNP XPA-A23G remained to be a significant predictor for the NER capacity after the intervention (Figure 3; $P=0.002$ ).

\section{Effects of dietary factors and gene-diet interactions on NER capacity}

The 4 week intervention with blueberry/apple juice was reported to be effective in the total study population $(n=168)$, as it significantly increased the total plasma antioxidant status, monitored as trolox equivalent antioxidant capacity (TEAC value) [22]. 


\section{Chapter 5}

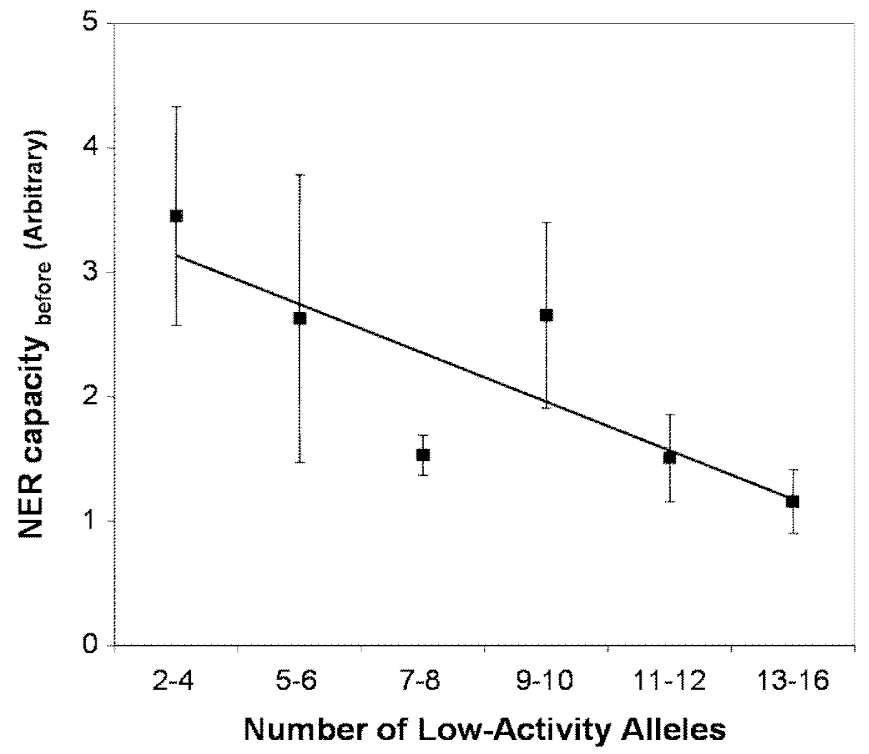

Figure 1. Relationship between NER capacity and the sum of low-activity alleles in NER related genes. The sum of low-activity alleles was computed for each individual by adding the number of alleles that putatively have adverse effects on DRC (Table II). An increase in this sum of total low-activity alleles was associated with decreased NER capacity $\left(R^{2}=0.68\right.$, $P=0.044)$. Data are presented as mean DRC \pm standard error of mean $(n=4-9)$.
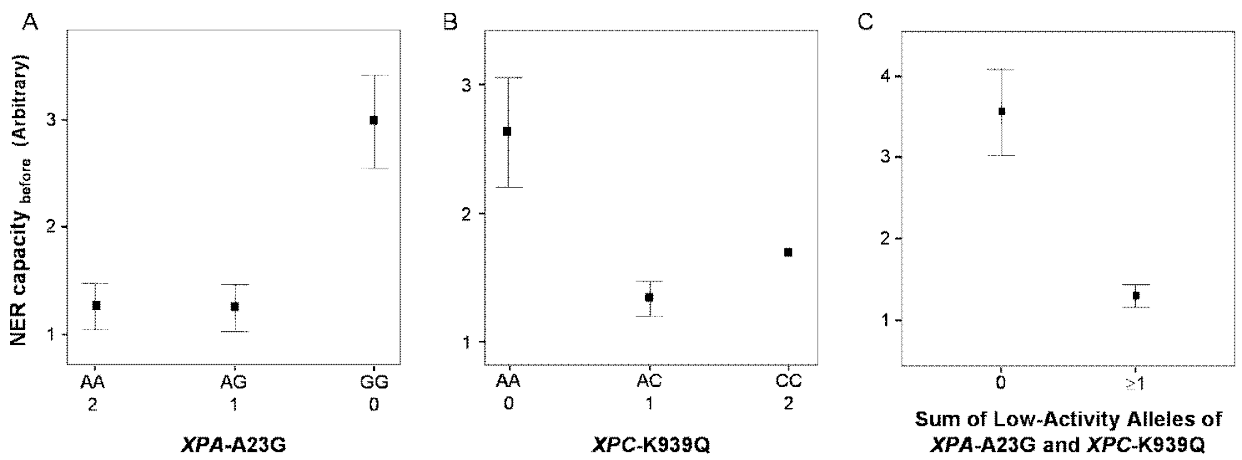

Figure 2. The effect of genetic polymorphisms on the phenotypic NER capacity assessed before the blue berry/apple juice intervention. NER capacity was significantly affected by (A) XPA-A23G ( $P=0.005)$ and (B) XPC-K939Q ( $P=0.050$; since there was only one individual with the $\mathrm{CC}$-genotype, subjects with the $\mathrm{AC}$ and $\mathrm{CC}$ genotypes were pooled for statistical reasons). (C) The effect of the sum of low-activity alleles for these two genes on NER capacity $(0=$ homozygous carriers of high-activity alleles in both XPA and XPC, $1=$ carriers of at least one low-activity allele in $X P A$ or $X P C)(P<0.001)$. Data are shown as mean NER capacities as computed from the TM values. Bars represent the standard error of the mean. 


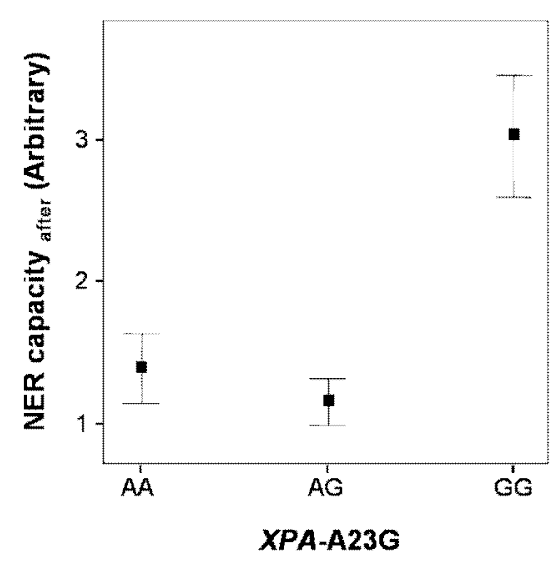

Figure 3. The effect of XPA-A23G polymorphism on the NER capacity assessed after the intervention with blue berry/apple juice $(P=0.002)$. Data are presented as mean NER capacities \pm SE.

Figure 5. The influence of specific genetic polymorphisms on the effect of the dietary intervention on NER capacity. Carriers of one or more low-activity alleles for XPC-K939Q and/or RAD23B-A249V showed an increased $\triangle$ NER capacity $(P=0.050)$ as compared to individuals with none of the low activity alleles. Data are presented as $\Delta$ of the mean NER capacities $( \pm S E)$.

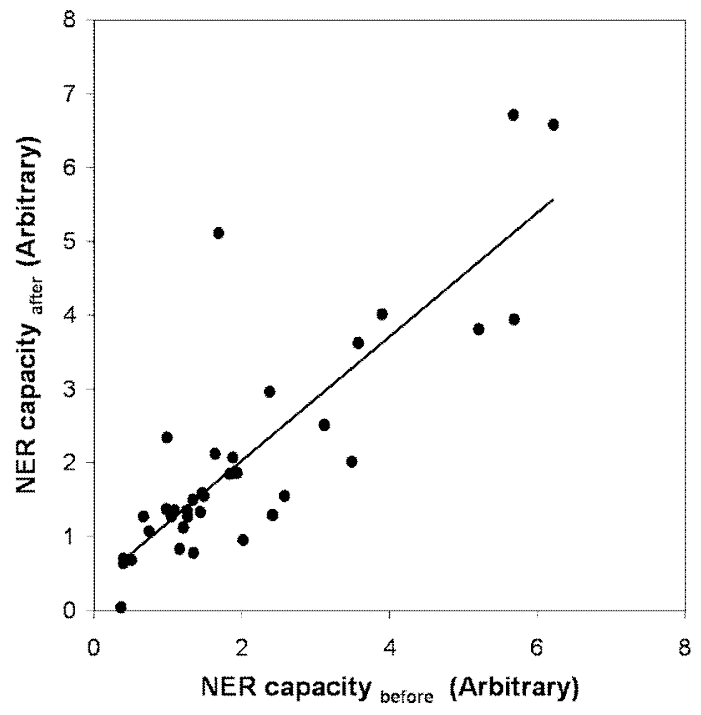

Figure. 4. Correlation between the NER capacities measured before and after the blueberry/apple juice intervention $\left(R^{2}=0.7051, P<0.001\right.$, slope $\left.=0.947\right)$.

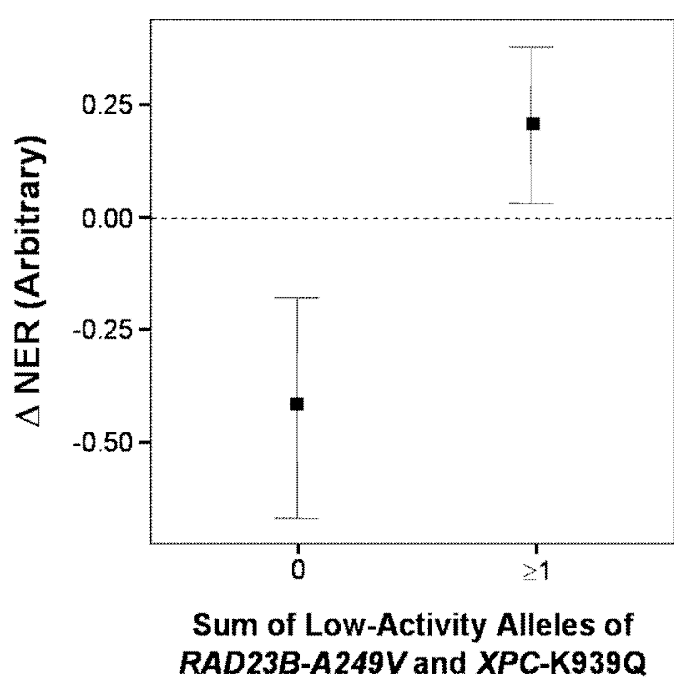




\section{Chapter 5}

Similar results were found for the selected subpopulation $(n=36)$; mean TEAC values were significantly elevated $(P=0.032)$ from $791 \mu \mathrm{M}( \pm 6.61)$ to $805 \mu \mathrm{M}$ $( \pm 7.90)$. However, when studying the effect of the dietary intervention on DRC, no clear effects of the 4 week blueberry/apple juice intervention on the phenotypically assessed NER capacity and no significant correlations between DRC and TEAC values were observed. In fact, NER capacities measured before the intervention correlated strongly with the NER capacities detected after the intervention (Figure 4; $\mathrm{R}^{2}=0.71, \mathrm{P}<0.001$, slope=0.95).

Although the diet did not affect the repair capacity in general, it can be postulated that individuals with a certain genetic background may still benefit. To further study gene-diet interactions regarding changes in DRC, differences between the NER capacities measured after and before the intervention were calculated for each individual $\left(\triangle N E R=N E R_{\text {after }}-N E R_{\text {before}}\right)$. This $\triangle N E R$, as an indicator of the intervention effect, was tested by multiple stepwise linear regression analysis against all SNPS, $\triangle T E A C$, age and sex. No effects of sex, age and $\triangle T E A C$ were observed. However, the intervention differentially affected NER capacity in subjects that carried the SNPS XPC-K939Q and RAD23B-A249V. Interestingly, the homozygous wild-types carriers of XPC-K939Q $(n=20)$ that previously showed a $\sim 2-$ fold higher NER capacity than homozygous carriers of the variant/low-activity allele $(n=1)$, benefited less from the intervention with the blueberry/apple juice as compared to those that carried the variant alleles ( $\triangle$ NER was $-0.19 \pm 0.18$ resp. 3.42 ; $\mathrm{P}<0.001$ ). Also for RAD23B-A249V, we observed that homozygous carriers of the low-activity alleles $(n=4)$ benefited more from the intervention by a significantly increased NER capacity as compared to subjects homozygous for the wildtype/high-activity allele $(n=20)(\triangle N E R$ was $1.03 \pm 0.89$ resp. $-0.20 \pm 0.16 ; P=0.026)$. The influence of the sum of low-activity alleles in XPC-K939Q and RAD23B-A249V on the $\triangle N E R$ showed a small but statistically significant increase in NER capacity upon the intervention for those having more than 1 low-activity allele $(n=25)$ compared with those carrying no low activity alleles ( $n=11)$ (Figure 5; $P=0.050)$.

Similar results were observed when considering the total sum of low-activity alleles in all studied genes; a mean $\triangle \mathrm{NER}( \pm \mathrm{SE})$ of $-0.19 \pm 0.18$ was observed for carriers of $<9$ low-activity alleles $(n=9)$, which increased to a mean $\triangle N E R$ of $0.22 \pm$ 0.23 for carriers of $\geq 9$ low-activity alleles $(n=11)$. In other words: again improved NER capacity upon dietary intervention was detected in individuals carrying multiple low-activity alleles. It should be noted here, however, that the effects of the dietary intervention on the phenotype-genotype relationships were considerably smaller than the effect of the genotype alone. Variations in NER capacity between carriers of high-activity alleles and carriers of one or more low-activity alleles were in the range of 3-fold, whereas differences in DRC upon intervention $(\triangle N E R)$ were merely in the range of -0.5 to +0.5 . 


\section{Discussion}

There is increasing evidence for an association between genetic polymorphisms in DNA repair related genes and cancer risk [1-4]. An obvious rationale behind this relationship is that genetic polymorphisms may phenotypically alter DRC. In the current study, eleven genetic polymorphisms in NER related genes were assessed and related to an individual's phenotypic DRC; variant alleles of the SNP XPA-A23G conferred increased NER capacity, while the variant alleles of XPC-K939Q were associated with reduced NER capacity. Furthermore, the effect of a four week dietary intervention with an antioxidant rich blueberry/apple juice on the phenotypic NER capacity was evaluated and possible genotype-diet interactions were studied. Although, the NER capacity was not affected by the dietary intervention in general, carriers of variant/low-activity alleles of XPC-K939Q and RAD23B-A249V seemed to benefit from the intervention, which was not observed in their homozygous wild-type counterparts. Therefore, our results support the hypothesis that genetic polymorphisms significantly affect DRC, which can be further modulated by diet. However, in this particular study, the effect of diet seems to play a minor role as compared to the effects of genotypic variation.

Although the majority of genes encoding proteins involved in DNA repair processes are polymorphic [28], only a limited number of studies have examined the actual phenotypic effects of these genetic polymorphisms. Therefore, our first aim was to further elucidate these genotype-phenotype relationships with respect to the NER process. In one of our previous studies, we observed a significant correlation between the ERCC1 expression and the phenotypic NER capacity in vitro [20]. Furthermore, several studies indicate that the polymorphism in ERCC1 may partly determine NER capacity $[29,30]$. ERCC1 encodes a subunit of the NER complex, which is required for the incision step of NER [6,7]. The common polymorphisms ERCC1-N118N and Q504K, which have been reported to affect ERCC1 mRNA stability and mRNA levels, were associated with a higher risk for certain types of cancer [31]. Based on these results, we expected to find associations with SNPs in the ERCC1 gene. However, we did not observe any significant correlation of the studied ERCC1 polymorphisms with the NER capacity in the present work. Since the functional relevance of SNPs in ERCC1 remains unclear and inconsistent results have been reported [30,32], further investigation into the effect of these polymorphisms on DRC is needed.

On the other hand, individuals with the common XPA-A23G homozygous variant GG genotype exhibited a significantly $\sim 3$-fold higher NER capacity compared to carriers of at least one wild-type allele. The XPA protein is involved in both global genome (GGR) and transcription-coupled repair pathway of the NER process, playing an essential role in the assembly of the pre-incision complex [7]. In the GGR pathway XPA binds to the protein complex XPC-RAD23B, which is essential for the recruitment of all subsequent NER factors in the pre-incision complex. The common $A \rightarrow G$ single-nucleotide substitution in the $5^{\prime}$ untranslated region (5'-UTR) of the 


\section{Chapter 5}

$X P A$ gene, is located 4 nucleotides upstream from the ATG start codon [33]. The functional relevance of this SNP is unknown, though, it has been demonstrated that the 5'-UTR region may regulate gene expression through post-transcriptional control mechanisms [34,35]. In addition, several studies showed that individuals with this $A \rightarrow G$ substitution in the 5'-UTR of XPA had a reduced risk of lung cancer $[10,36,37]$. Furthermore, in correspondence to our results, Wu et al. observed a more efficient DRC in subjects carrying the XPA-GG variant alleles [10]. Moreover in the current study, the association between this XPA polymorphism and NER capacity was also found after the blueberry/apple juice intervention, indicating that the XPA-A23G SNP is a good predictor for NER capacity.

One of the most common polymorphisms in the XPC gene is the K939Q $(A \rightarrow C)$, of which the variant allele has been associated with increased risk of skin [38], breast [39], lung [36], and bladder cancer [40,41]. In this study, carrying at least one variant allele of $X P C-K 939 Q$ reduced NER capacity to ca. $50 \%$ as compared to individuals carrying the homozygous wild-type genotype. Similarly, the variant allele of the XPC-K939Q polymorphism was shown to be associated with depressed levels of NER in vitro [42]. Furthermore, others observed significantly higher BPDEinduced and irradiation-induced levels of DNA damage in individuals that carried the variant allele of $X P C-K 939 Q[9,43]$.

In our previous in vitro study [20], we observed that NER activity was inhibited by oxidative stress, especially by the down-regulation of ERCC1 expression. It can thus be postulated that a diet rich in antioxidants may protect NER. However, no effects were found in the current intervention study on NER capacity. A reasonable explanation for the absence of dietary effects in the current study is that the study population consisted of healthy non-smoking volunteers. Since healthy volunteers encounter relatively low levels of oxidative stress, it may be difficult to detect small additional effects of dietary intake of antioxidants. Future studies on the beneficial effects of diets rich in antioxidants should thus focus on for instance subjects suffering form diseases that involve increased oxidative stress. Additionally, in the current intervention study, we observed a strong correlation between the NER capacity before and after the supplementation period $\left(R^{2}=0.71, P<0.001\right)$, indicating that inter-individual variations in NER are maintained over a considerable time, which has also been reported for BER [44]. In contrast, BER seems to be modifiable by the intake of antioxidants even in healthy subjects [45], but data are not consistent $[46,47]$.

Although we did not observe an overall effect of diet on NER capacity, it is still possible that a subgroup may benefit from the intervention (gene-diet interactions). Indeed, subjects carrying variant alleles for XPC-K939Q and/or RAD23B-A249V had enhanced NER capacities after the intervention. The protein encoded by $R A D 23 B$ binds XPC, forming a heterodimeric complex, which plays a key part in the DNA damage recognition step in the NER GGR pathway [7]. Although, the biological function of the RAD23B-A249V polymorphism is not clear, variant alleles of $R A D 23 B-A 249 V$ were associated with increased lung cancer risk and higher BPDE 
sensitivity as compared to the homozygous wild-types [2,3]. It is interesting to find that genetic polymorphisms in both $X P C$ as well as $R A D 23 B$ interact in the intervention study, because the proteins of both genes also interact during their function in NER.

Furthermore, the enhanced NER capacities seemed to be associated with increased TEAC values in subjects that carry $\geq 1$ low-activity allele of XPC-K939Q and $R A D 23 B-\mathrm{A} 249 \mathrm{~V}$, though, this correlation was not statistically significant. It is not yet clear how this interaction between the genotype and antioxidant intake can be explained, but it deserves extra attention. Therefore, further and larger studies are needed to clarify possible correlations between an individual's antioxidant capacity and DNA repair capacity, both in the whole population as in several subgroups. Until now only a few studies have investigated the interrelationship between genetic polymorphisms in DNA repair genes and fruit/vegetables intake, mostly in relation to cancer risk and not directly linked to actual repair capacities $[48,49]$. As far as we know, we are the first to report a joint effect of genetic polymorphisms in NER related genes and dietary intervention on the phenotypically assessed NER capacity.

Overall, our results show that genetic factors have more impact on the NER capacity as compared to the effects of the blueberry/apple juice intervention. Furthermore, the common genetic polymorphism XPA-A23G revealed to be a good predictor for the NER capacity, which was not affected by the dietary intervention. The XPC-K939Q variant allele was found to be related to lower NER capacity, but this association was affected by gene-diet interactions as carriers of the XPC$\mathrm{K} 939 \mathrm{Q}$ variant allele in combination with the $R A D 23 B-\mathrm{A} 249 \mathrm{~V}$ variant allele showed an increased NER capacity upon intervention with blueberry/apple juice. In conclusion, studies to genotype-phenotype interactions seem to be helpful in the identification of susceptible subpopulations and individuals that may benefit from specific dietary interventions. However, further and larger studies into the joint effect of genetic and dietary factors on the phenotypic DNA repair capacity are required.

\section{Acknowledgement}

Part of the studies was supported by the European Network of Excellence (NoE) "Environmental Cancer risk, Nutrition and Individual Susceptibility" (ECNIS), sixth Framework programme (FP6), FOOD-CT-2005-513943. The intervention study was funded by the Netherlands Organisation for Health Research and Development. Nutrition: Health, Safety and Sustainability program. Grant number 01412012. Furthermore, we thank Ralph W.H. Gottschalk for his assistance in the set up of the Multiplex SNaPShot PCR and Stijn B.J. Lumeij for his technical support in the in vitro DNA repair assays. 


\section{References}

1. Andrew A. S., Nelson H. H., Kelsey K. T., Moore J. H., Meng A. C., Casella D. P., Tosteson T. D., Schned A. R. and Karagas M. R. Concordance of multiple analytical approaches demonstrates a complex relationship between DNA repair gene SNPs, smoking and bladder cancer susceptibility. Carcinogenesis 2006;27:1030-1037.

2. Lin J., Swan G. E., Shields P. G., Benowitz N. L., Gu J., Amos C. I., de Andrade M., Spitz M. R. and Wu X. Mutagen sensitivity and genetic variants in nucleotide excision repair pathway: genotype-phenotype correlation. Cancer Epidemiol Biomarkers Prev 2007;16:2065-2071.

3. Shen M., Berndt S. I., Rothman N., Demarini D. M., Mumford J. L., He X., Bonner M. R., Tian L., Yeager M., Welch R., Chanock S., Zheng T., Caporaso N. and Lan Q. Polymorphisms in the DNA nucleotide excision repair genes and lung cancer risk in Xuan Wei, China. Int J Cancer 2005;116:768-773.

4. Wei Q. and Spitz M. R. The role of DNA repair capacity in susceptibility to lung cancer: a review. Cancer Metastasis Rev 1997;16:295-307.

5. Friedberg E. C. How nucleotide excision repair protects against cancer. Nat Rev Cancer 2001;1:22-33.

6. Sancar A., Lindsey-Boltz L. A., Unsal-Kacmaz K. and Linn S. Molecular mechanisms of mammalian DNA repair and the DNA damage checkpoints. Annu Rev Biochem 2004;73:39-85.

7. Sugasawa K. Xeroderma pigmentosum genes: functions inside and outside DNA repair. Carcinogenesis 2008;29:455-465.

8. Bootsma D., Kraemer K.H., Cleaver J.E. and Hoeijmakers J.H.J. Nucleotide excision repair syndromes: xeroderma pigmentosum, Cockayne syndrome, and trichothiodystrophy. In: Vogelstein B. and Kinzler K.W., The Genetic Basis of Human Cancer, Vol.2., McGraw-Hill, New York, 2002, pp. 211-237.

9. Zhu Y., Yang H., Chen Q., Lin J., Grossman H. B., Dinney C. P., Wu X. and Gu J. Modulation of DNA damage/DNA repair capacity by XPC polymorphisms. DNA Repair (Amst) 2008;7:141-148.

10. Wu X., Zhao H., Wei Q., Amos C. I., Zhang K., Guo Z., Qiao Y., Hong W. K. and Spitz M. R. XPA polymorphism associated with reduced lung cancer risk and a modulating effect on nucleotide excision repair capacity. Carcinogenesis 2003;24:505-509.

11. Dusinska M., Dzupinkova Z., Wsolova L., Harrington V. and Collins A. R. Possible involvement of XPA in repair of oxidative DNA damage deduced from analysis of damage, repair and genotype in a human population study. Mutagenesis 2006;21:205-211.

12. Matullo G., Palli D., Peluso M., Guarrera S., Carturan S., Celentano E., Krogh V., Munnia A., Tumino R., Polidoro S., Piazza A. and Vineis P. XRCC1, XRCC3, XPD gene polymorphisms, smoking and (32)P-DNA adducts in a sample of healthy subjects. Carcinogenesis 2001;22:1437-1445.

13. Shen J., Gammon M. D., Terry M. B., Wang L., Wang Q., Zhang F., Teitelbaum S. L., Eng S. M., Sagiv S. K., Gaudet M. M., Neugut A. I. and Santella R. M. Polymorphisms in XRCC1 modify the association between polycyclic aromatic hydrocarbon-DNA adducts, cigarette smoking, dietary antioxidants, and breast cancer risk. Cancer Epidemiol Biomarkers Prev 2005;14:336-342.

14. Cheng J., Leng S., Dai Y., Huang C., Pan Z., Niu Y., Li B. and Zheng Y. Association between nucleotide excision repair gene polymorphisms and chromosomal damage in coke-oven workers. Biomarkers 2007;12:76-86.

15. Mateuca R., Aka P. V., De Boeck M., Hauspie R., Kirsch-Volders M. and Lison D. Influence of hOGG1, XRCC1 and XRCC3 genotypes on biomarkers of genotoxicity in workers exposed to cobalt or hard metal dusts. Toxicol Lett 2005;156:277-288. 
16. Mateuca R. A., Roelants M., larmarcovai G., Aka P. V., Godderis L., Tremp A., Bonassi S., Fenech M., Berge-Lefranc J. L. and Kirsch-Volders M. hOGG1(326), XRCC1(399) and XRCC3(241) polymorphisms influence micronucleus frequencies in human lymphocytes in vivo. Mutagenesis 2008;23:35-41.

17. Food, Nutrition and the Prevention of Cancer: A Global Perspective. World Cancer Research Fund / American Institute for Cancer Research. London:WCRF UK; 1997.

18. Tyson J. and Mathers J. C. Dietary and genetic modulation of DNA repair in healthy human adults. Proc Nutr Soc 2007;66:42-51.

19. Wei Q., Shen H., Wang L. E., Duphorne C. M., Pillow P. C., Guo Z., Qiao Y. and Spitz M. R. Association between low dietary folate intake and suboptimal cellular DNA repair capacity. Cancer Epidemiol Biomarkers Prev 2003;12:963-969.

20. Langie S. A., Knaapen A. M., Houben J. M., van Kempen F. C., de Hoon J. P., Gottschalk R. W., Godschalk R. W. and van Schooten F. J. The role of glutathione in the regulation of nucleotide excision repair during oxidative stress. Toxicol Lett 2007;168:302-309.

21. Gungor N., Godschalk R. W., Pachen D. M., Van Schooten F. J. and Knaapen A. M. Activated neutrophils inhibit nucleotide excision repair in human pulmonary epithelial cells: role of myeloperoxidase. Faseb J 2007;21:2359-2367.

22. Wilms L. C., Boots A. W., de Boer V. C., Maas L. M., Pachen D. M., Gottschalk R. W., Ketelslegers H. B., Godschalk R. W., Haenen G. R., van Schooten F. J. and Kleinjans J. C. Impact of multiple genetic polymorphisms on effects of a 4-week blueberry juice intervention on ex vivo induced lymphocytic DNA damage in human volunteers. Carcinogenesis 2007;28:1800-1806.

23. Wilms L. C., Hollman P. C., Boots A. W. and Kleinjans J. C. Protection by quercetin and quercetin-rich fruit juice against induction of oxidative DNA damage and formation of BPDE-DNA adducts in human lymphocytes. Mutat Res 2005;582:155162.

24. Langie S. A., Knaapen A. M., Brauers K. J., van Berlo D., van Schooten F. J. and Godschalk R. W. Development and validation of a modified comet assay to phenotypically assess nucleotide excision repair. Mutagenesis 2006;21:153-158.

25. Boyum A. Isolation of lymphocytes, granulocytes and macrophages. Scand $J$ Immunol 1976; Suppl 5:9-15.

26. Knaapen A. M., Ketelslegers H. B., Gottschalk R. W., Janssen R. G., Paulussen A. D., Smeets H. J., Godschalk R. W., Van Schooten F. J., Kleinjans J. C. and Van Delft J. H. Simultaneous genotyping of nine polymorphisms in xenobioticmetabolizing enzymes by multiplex PCR amplification and single base extension. Clin Chem 2004;50:1664-1668.

27. Ketelslegers H. B., Gottschalk R. W., Godschalk R. W., Knaapen A. M., van Schooten F. J., Vlietinck R. F., Kleinjans J. C. and van Delft J. H. Interindividual variations in DNA adduct levels assessed by analysis of multiple genetic polymorphisms in smokers. Cancer Epidemiol Biomarkers Prev 2006;15:624-629.

28. Mohrenweiser H. W., Xi T., Vazquez-Matias J. and Jones I. M. Identification of 127 amino acid substitution variants in screening 37 DNA repair genes in humans. Cancer Epidemiol Biomarkers Prev 2002;11:1054-1064.

29. Vogel U., Dybdahl M., Frentz G. and Nexo B. A. DNA repair capacity: inconsistency between effect of over-expression of five NER genes and the correlation to mRNA levels in primary lymphocytes. Mutat Res 2000;461:197-210.

30. Zhou W., Liu G., Park S., Wang Z., Wain J. C., Lynch T. J., Su L. and Christiani D. C. Gene-smoking interaction associations for the ERCC1 polymorphisms in the risk of lung cancer. Cancer Epidemiol Biomarkers Prev 2005;14:491-496.

31. Chen P., Wiencke J., Aldape K., Kesler-Diaz A., Miike R., Kelsey K., Lee M., Liu J. and Wrensch M. Association of an ERCC1 polymorphism with adult-onset glioma. Cancer Epidemiol Biomarkers Prev 2000;9:843-847. 
32. Zienolddiny S., Campa D., Lind H., Ryberg D., Skaug V., Stangeland L., Phillips D. $\mathrm{H}$., Canzian F. and Haugen A. Polymorphisms of DNA repair genes and risk of nonsmall cell lung cancer. Carcinogenesis 2006;27:560-567.

33. Butkiewicz D., Rusin M., Harris C. C. and Chorazy M. Identification of four single nucleotide polymorphisms in DNA repair genes: XPA and XPB (ERCC3) in Polish population. Hum Mutat 2000;15:577-578.

34. Akiri G., Nahari D., Finkelstein Y., Le S. Y., Elroy-Stein O. and Levi B. Z. Regulation of vascular endothelial growth factor (VEGF) expression is mediated by internal initiation of translation and alternative initiation of transcription. Oncogene 1998;17:227-236.

35. Larsen L. K., Amri E. Z., Mandrup S., Pacot C. and Kristiansen K. Genomic organization of the mouse peroxisome proliferator-activated receptor beta/delta gene: alternative promoter usage and splicing yield transcripts exhibiting differential translational efficiency. Biochem J 2002;366:767-775.

36. Vogel U., Overvad K., Wallin H., Tjonneland A., Nexo B. A. and Raaschou-Nielsen O. Combinations of polymorphisms in XPD, XPC and XPA in relation to risk of lung cancer. Cancer Lett 2005;222:67-74.

37. Butkiewicz D., Popanda O., Risch A., Edler L., Dienemann H., Schulz V., Kayser K., Drings P., Bartsch H. and Schmezer P. Association between the risk for lung adenocarcinoma and a (-4) G-to-A polymorphism in the XPA gene. Cancer Epidemiol Biomarkers Prev 2004;13:2242-2246.

38. Blankenburg S., Konig I. R., Moessner R., Laspe P., Thoms K. M., Krueger U., Khan S. G., Westphal G., Berking C., Volkenandt M., Reich K., Neumann C., Ziegler A., Kraemer K. H. and Emmert S. Assessment of 3 xeroderma pigmentosum group $\mathrm{C}$ gene polymorphisms and risk of cutaneous melanoma: a case-control study. Carcinogenesis 2005;26:1085-1090.

39. Zhang L., Zhang Z. and Yan W. Single nucleotide polymorphisms for DNA repair genes in breast cancer patients. Clin Chim Acta 2005;359:150-155.

40. Garcia-Closas M., Malats N., Real F. X., Welch R., Kogevinas M., Chatterjee N., Pfeiffer R., Silverman D., Dosemeci M., Tardon A., Serra C., Carrato A., GarciaClosas R., Castano-Vinyals G., Chanock S., Yeager M. and Rothman N. Genetic variation in the nucleotide excision repair pathway and bladder cancer risk. Cancer Epidemiol Biomarkers Prev 2006;15:536-542.

41. Sanyal S., Festa F., Sakano S., Zhang Z., Steineck G., Norming U., Wijkstrom H., Larsson P., Kumar R. and Hemminki K. Polymorphisms in DNA repair and metabolic genes in bladder cancer. Carcinogenesis 2004;25:729-734.

42. Qiao Y., Spitz M. R., Shen H., Guo Z., Shete S., Hedayati M., Grossman L., Mohrenweiser $\mathrm{H}$. and Wei $\mathrm{Q}$. Modulation of repair of ultraviolet damage in the hostcell reactivation assay by polymorphic XPC and XPD/ERCC2 genotypes. Carcinogenesis 2002;23:295-299.

43. Vodicka P., Kumar R., Stetina R., Sanyal S., Soucek P., Haufroid V., Dusinska M., Kuricova M., Zamecnikova M., Musak L., Buchancova J., Norppa H., Hirvonen A., Vodickova L., Naccarati A., Matousu Z. and Hemminki K. Genetic polymorphisms in DNA repair genes and possible links with DNA repair rates, chromosomal aberrations and single-strand breaks in DNA. Carcinogenesis 2004;25:757-763.

44. Collins A. R., Dusinska M., Horvathova E., Munro E., Savio M. and Stetina R. Interindividual differences in repair of DNA base oxidation, measured in vitro with the comet assay. Mutagenesis 2001;16:297-301.

45. Collins A. R., Harrington V., Drew J. and Melvin R. Nutritional modulation of DNA repair in a human intervention study. Carcinogenesis 2003;24:511-515.

46. Moller $\mathrm{P}$. and Loft $\mathrm{S}$. Interventions with antioxidants and nutrients in relation to oxidative DNA damage and repair. Mutat Res 2004;551:79-89.

47. Moller P., Vogel U., Pedersen A., Dragsted L. O., Sandstrom B. and Loft S. No effect of 600 grams fruit and vegetables per day on oxidative DNA damage and 
repair in healthy nonsmokers. Cancer Epidemiol Biomarkers Prev 2003;12:10161022.

48. van Gils C. H., Bostick R. M., Stern M. C. and Taylor J. A. Differences in base excision repair capacity may modulate the effect of dietary antioxidant intake on prostate cancer risk: an example of polymorphisms in the XRCC1 gene. Cancer Epidemiol Biomarkers Prev 2002;11:1279-1284.

49. Misra R. R., Ratnasinghe D., Tangrea J. A., Virtamo J., Andersen M. R., Barrett M., Taylor P. R. and Albanes D. Polymorphisms in the DNA repair genes XPD, XRCC1, XRCC3, and APE/ref-1, and the risk of lung cancer among male smokers in Finland. Cancer Lett 2003;191:171-178.

50. Shen J., Desai M., Agrawal M., Kennedy D. O., Senie R. T., Santella R. M. and Terry M. B. Polymorphisms in nucleotide excision repair genes and DNA repair capacity phenotype in sisters discordant for breast cancer. Cancer Epidemiol Biomarkers Prev 2006;15:1614-1619.

51. Chen M., Kamat A. M., Huang M., Grossman H. B., Dinney C. P., Lerner S. P., Wu $\mathrm{X}$. and $\mathrm{Gu}$ J. High-order interactions among genetic polymorphisms in nucleotide excision repair pathway genes and smoking in modulating bladder cancer risk. Carcinogenesis 2007;28:2160-2165.

52. Gu J., Zhao H., Dinney C. P., Zhu Y., Leibovici D., Bermejo C. E., Grossman H. B. and $\mathrm{Wu} X$. Nucleotide excision repair gene polymorphisms and recurrence after treatment for superficial bladder cancer. Clin Cancer Res 2005;11:1408-1415.

53. Ma H., Xu L., Yuan J., Shao M., Hu Z., Wang F., Wang Y., Yuan W., Qian J., Wang Y., Xun P., Liu H., Chen W., Yang L., Jin G., Huo X., Chen F., Shugart Y. Y., Jin L., Wei Q., Wu T., Shen H., Huang W. and Lu D. Tagging single nucleotide polymorphisms in excision repair cross-complementing group 1 (ERCC1) and risk of primary lung cancer in a Chinese population. Pharmacogenet Genomics 2007;17:417-423. 



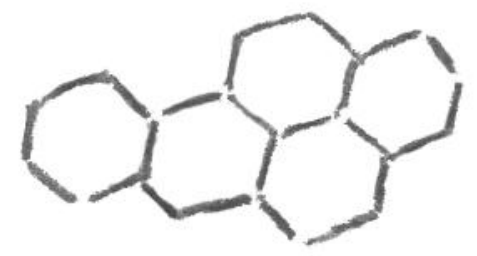

\section{Chapter 6}

\section{Formation of Lysine 63-linked poly-ubiquitin chains protects human lung cells against benzo(a)pyrene-diol-epoxide- induced mutagenicity}

Published in DNA Repair 2007;6:852-862

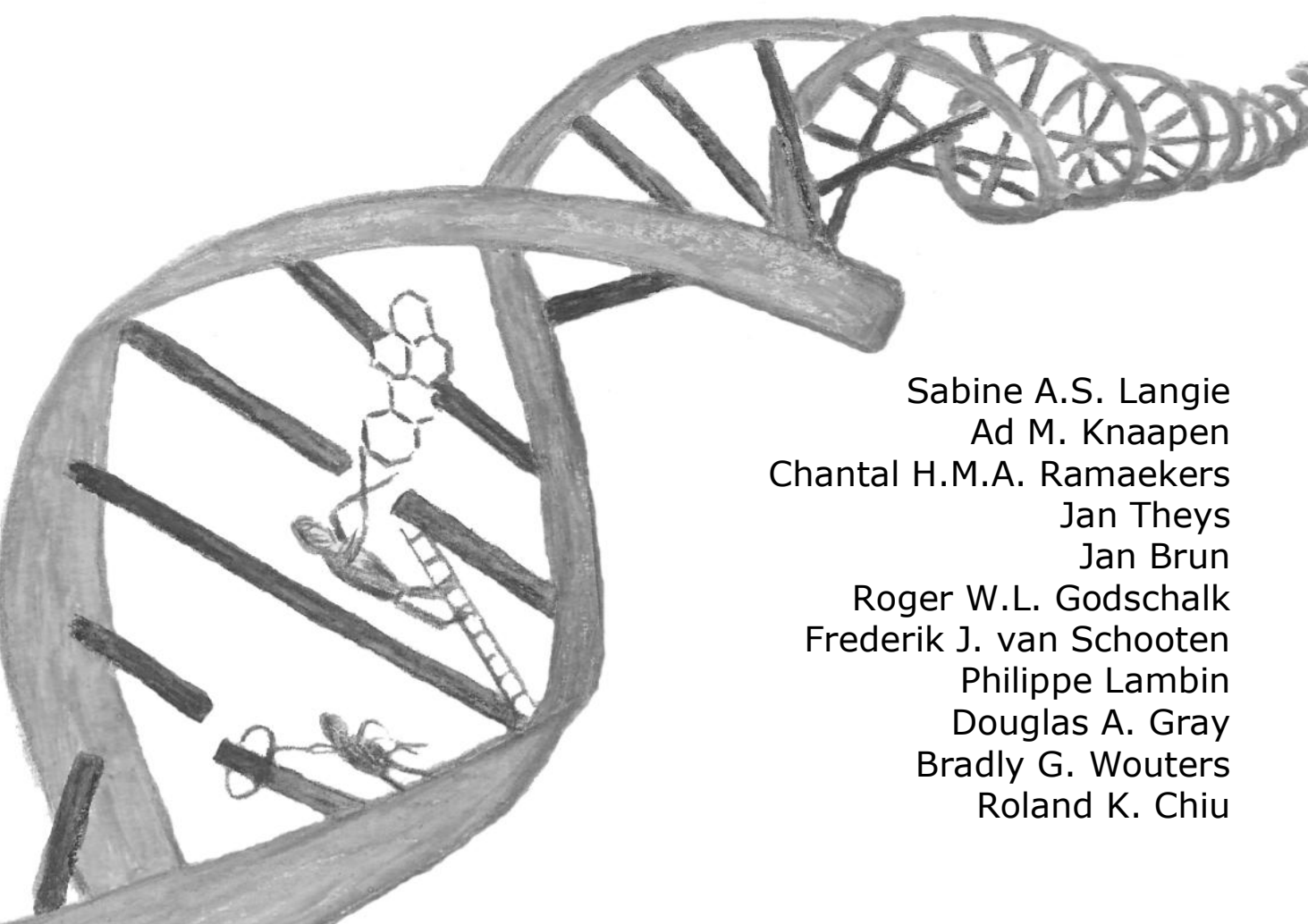




\section{Chapter 6}

\section{Abstract}

Benzo(a)pyrene exerts its mutagenic effects via induction of benzo(a)pyrene-diolepoxide (BPDE)-DNA adducts. Such helix-distorting adducts are not always successfully repaired prior to DNA replication, which may result in a blocked replication fork. To alleviate this stall, cells utilize DNA damage tolerance systems involving either error-free damage avoidance or error-prone translesion synthesis. Studies in yeast suggest the modification of PCNA by lysine 63-linked poly-ubiquitin (K63-polyUb) chains as a key mediator of the error-free damage avoidance pathway. Recently, we extended this observation to human cells, showing the occurrence of poly-ubiquitination of PCNA in UV-irradiated human cells. In the present study, we hypothesized that disrupting the formation of K63-polyUb chains inhibits damage avoidance and favors error-prone repair involving low-fidelity polymerases (e.g. POL $)$ ), causing increased BPDE-induced mutagenicity. To test this hypothesis, we generated A549 cells expressing either a mutant ubiquitin $(K 63 R-U b)$ which blocks further ubiquitination through $\mathrm{K} 63$, or the wild type ubiquitin $(W T-U b)$. We show that PCNA is poly-ubiquitinated in these cells upon BPDEexposure and that disruption of K63-polyUb chain formation has no effect on BPDEinduced toxicity. In contrast, significantly higher frequencies of BPDE-induced HPRT mutations were observed in K63R-Ub expressing cells, of which the majority $(74 \%)$ was $\mathrm{G} \rightarrow \mathrm{T}$ transversions. BPDE treatment caused an enhanced recruitment of POL $\eta$ to the replication machinery of the $K 63 R-U b$ expressing cells, where it co-localized with PCNA. Suppression of POL $\eta$ expression by using siRNA resulted in a $50 \%$ reduction of BPDE-induced mutations in the K63R cells. In conclusion, we demonstrated that formation of K63-polyUb chains protects BPDE-exposed human cells against translesion synthesis-mediated mutagenesis. These findings indicate that K63-polyubiquitination guards against chemical carcinogenesis by preventing mutagenesis and thus contributing to genomic stability. 


\section{Introduction}

Humans are continuously exposed to a wide variety of DNA-damaging environmental carcinogens such as polycyclic aromatic hydrocarbons (PAHs). The most studied PAH is benzo[a]pyrene (B[a]P) whose mutagenic and carcinogenic potential has been demonstrated in both humans and animals [1]. After uptake, the chemically unreactive $\mathrm{B}[\mathrm{a}] \mathrm{P}$ is metabolically activated into its predominant reactive form, ( \pm )-anti-benzo[a]pyrene-7,8-dihydrodiol-9,10-epoxide (BPDE). This metabolite can covalently bind to the DNA, preferably to guanine, resulting in the formation of $(+)$-trans-anti-BPDE- $N^{2}-\mathrm{dG}$ being the most predominant adduct $(>90 \%)$ [1-3]. The formation of these $( \pm)$-anti-BPDE- $N^{2}-\mathrm{dG}$ DNA adducts is one of the key factors of $\mathrm{B}[\mathrm{a}] \mathrm{P}$-induced mutagenesis, producing mostly $\mathrm{G} \rightarrow \mathrm{T}$ transversions upon errorprone replication of adducted DNA templates [4].

Generally, nucleotide excision repair (NER) is the primary pathway to remove large helix-distorting DNA lesion, such as BPDE-DNA adducts. Nevertheless, despite NER activity and the presence of cell-cycle checkpoints, many of such bulky lesions may persist until replication, thereby stalling the replication fork. To avoid an aberrant cessation of the cell-cycle caused by such a blockage, cells have evolved DNA damage tolerance (DDT) systems (also known as post-replication repair) to circumvent the damage and continue replication in the presence of lesions $[5,6]$. Studies in bacteria (E.coli), yeast as well as mammalian cells [5-8], revealed that DDT can be accomplished through the action of error-prone low-fidelity translesion synthesis (TLS) polymerases (e.g. Y-family DNA polymerases). Studies in mammalian cells have revealed TLS to be an important mechanism in the response to BPDE-DNA adducts [8,9]. In general, TLS can either be error-free or error-prone, depending on the type of DNA damage, as well as the specific polymerase that is involved. Candidates for performing TLS bypassing bulky-DNA adducts are POL $\eta$, POL $\kappa, P O L ı$, REV1 (Y-family polymerases) and POL $\zeta$ (B-family) $[6,10]$. In contrast to its anti-mutagenic role in response to UV radiation, bypass of ( \pm )-anti-BPDE-DNA adducts by POL $\eta$ will promote mutagenesis by predominantly inserting the incorrect nucleotide opposite the lesion [9,11].

There is now evidence showing that yeast have a second DDT pathway distinct from TLS, referred to as error-free damage avoidance. Although its mechanism is yet unclear, it may involve replication fork reversal, thereby using the information of the undamaged sister duplex at the replication fork $[12,13]$. Studies in yeast have shown that this pathway requires modification of proliferating cell nuclear antigen (PCNA) with lysine 63-linked polyUb (K63-polyUb) chains [12-14]. Specifically, upon exposure to DNA-damaging agents PCNA becomes mono-ubiquitinated by the ubiquitin conjugase-ubiquitin ligase (E2-E3) complex RAD6-RAD18 at its Lys164 residue, promoting its interaction with TLS-polymerases [12,15]. Subsequent Lys63linked poly-ubiquitination of PCNA by the E2-E3 complex UBC13/MMS2-RAD5 then facilitates the error-free damage avoidance pathway. As far as we know, only studies in yeast and metazoans (i.e. X. laevis) confirmed this K63-linked poly- 


\section{Chapter 6}

ubiquitination $[12,14,16]$, and there is still debate on the importance of such damage avoidance mechanism in mammalian cells [17]. However, we recently demonstrated the formation of PCNA-linked polyUb polymers in UV-exposed human pulmonary epithelial cells (A549 cells) [18]. In addition, in the same study it was shown that formation of K63-polyUb chains protected against UV-induced mutations. The aim of the present study was to investigate the effect of lysine 63-linked poly-ubiquitination processes on BPDE-induced mutagenesis in mammalian cells. To this end, we applied previously established A549 cell lines stably expressing ubiquitin either in its WT-form $(W T-U b)$ or as Lys63-mutants $(K 63 R-U b)$ which blocks further ubiquitination through K63 [18]. We show that PCNA is poly-ubiquitinated after BPDE treatment and that disruption of K63-polyUb chain formation enhances BPDE-induced mutagenicity, likely involving increased recruitment of the Y-family

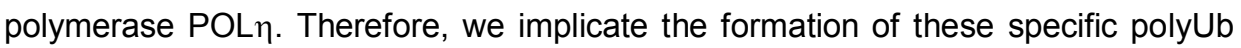
chains in the protection against chemical carcinogenesis.

\section{Materials and Methods}

\section{Cell strains and culture}

As previously described, A549 cells were stably transfected with 6xhis-tagged wildtype ubiquitin-GFP (WT-Ub-GFP) or K63R mutant ubiquitin-GFP (K63R-Ub-GFP) constructs using FuGene 6 (Roche Molecular Biochemicals, Mannheim, Germany) [19]. Plasmids were co-transfected with a plasmid conferring resistance to puromycin.

To study POL $\eta$-GFP foci formation, a set of A549 and HeLa cells were transfected with WT-Ub-puro or K63R-Ub-puro constructs using lipofectamin (Invitrogen Life Technologies, Carlsbad, California). These Ub-puro cell lines were phenotypically comparable to the original Ub-GFP expressing cells as demonstrated by Chiu et al. [18].

To assess the role of POL $\eta$ in the mutagenicity of BPDE, K63R-Ub expressing A549 cells were transfected twice with siGENOME SMARTpool reagent specific for human POLH (Dharmacon) using oligofectamine (Invitrogen). The transfections were done 72 and $24 \mathrm{~h}$ before treatment to achieve optimal long term knockdown of POL $\eta$ of approximately 13 fold as determined by quantitative RT-PCR, as described previously [18].

Cells were cultured in a humidified atmosphere at $37^{\circ} \mathrm{C}\left(5 \% \mathrm{CO}_{2}\right)$, in DMEM (Sigma, St. Louis) supplemented with 10\% heat inactivated FCS (Gibco Invitrogen, Scotland, UK) and $0.11 \%$ filtered puromycin $(1 \mu \mathrm{g} / \mathrm{mL})$ to establish stable transfectants. For experiments, cells were cultured in DMEM supplemented with $10 \%$ heat inactivated FCS and $0.01 \%$ gentamicin, and grown until confluency. 


\section{Cell treatments}

Before BPDE-exposure, medium was aspirated and cells were washed with sterile HBSS (-Ca/-Mg) (Gibco Invitrogen, Scotland, UK). BPDE ( $\mathrm{NCl}$ Chemical Carcinogen Reference Standard Repository, Midwest Research Institute, Kansas City, MO) was dissolved in anhydrous dimethyl sulfoxide (DMSO, Merck, Darmstadt, Germany) at a concentration of $20 \mathrm{mM}$. This stock solution was diluted in culture medium to the desired concentrations of $0.1-1 \mu \mathrm{M}$ and immediately added to the cells. The final DMSO concentration was always $0.5 \%$ [20]. After $30 \mathrm{~min}$ of incubation at $37^{\circ} \mathrm{C}$, medium containing BPDE was replaced by fresh culture medium. To study PCNA poly-ubiquitination, UV-irradiated cells were used as a positive control. This was performed on $80 \%$ confluent cells in $6-\mathrm{cm}$ dishes using a UVC (254-nm) germicidal lamp at a dose rate of $1 \mathrm{~J} / \mathrm{m}^{2} / \mathrm{s}$.

\section{Clonogenic cell survival}

The sensitivity of A549 cells expressing K63R-Ub or $W T-U b$ to BPDE was assayed using a clonogenic survival assay. Therefore, cells were seeded at a density of $4 \times 10^{5}$ cells per $60 \mathrm{~mm}$ dish (Falcon, Le Pont De Claix, France) and grown for $24 \mathrm{~h}$ before exposure to BPDE $(0-1.0 \mu \mathrm{M})$ or DMSO. Cells were treated for 30 min with the indicated dosages after which they were harvested and seeded at least in duplicate for each concentration. After $\sim 12$ days of growth the medium was removed and colonies were fixed and stained with $2 \%$ bromophenol blue in $70 \%$ ethanol. Any groupings of cells containing 50 or more cells were counted as a colony. For each dose, survival was calculated from the relative colony forming ability of the BPDE-exposed cells compared to the DMSO-treated controls. All experiments were normalized for the plating efficiency. $L_{50}$ values were estimated from the obtained concentration-response curves.

\section{HPRT-mutation analysis}

For the determination of HPRT-mutant frequencies in K63R-Ub and $W T-U b$ expressing cells, cells were seeded at $1 \times 10^{6}$ cells per $100 \mathrm{~mm}$ dish (Falcon, Le Pont De Claix, France) and cultured in hypoxanthine, aminopterin, and thymidine (HAT) supplemented culture medium for one week, to eliminate background HPRT mutations. Subsequently, cells were exposed to the indicated concentrations of $\operatorname{BPDE}\left(30 \mathrm{~min}, 37^{\circ} \mathrm{C}\right.$ ) and were maintained for one week to allow for phenotypic expression of the acquired mutations. Cells carrying mutated HPRT were then selected in gentamicin-containing medium supplemented with $30 \mu \mathrm{M}$ 6-thioguanine (6-TG). After $\sim 14$ days of culture, cells were fixed and stained with $2 \%$ bromophenol blue in $70 \%$ ethanol. 6-TG resistant colonies consisting of 50 or more cells were counted. In parallel, cells were plated (200 cells/100 mm dish) in medium lacking 6TG to determine the plating efficiency at the time of selection. Mutation frequency for each treatment was calculated as follows; mutation frequency = \# colonies/(plating efficiency $x$ \# cells seeded). 


\section{Chapter 6}

\section{Mutation spectrum}

BPDE-induced HPRT mutants were obtained as described above. To excluded sister clones only a single colony per treated population was isolated and grown in 6 well plates until enough cells were obtained for RNA-isolation. Each sample was lysed in $1 \mathrm{~mL}$ Trizol and stored at $-20^{\circ} \mathrm{C}$ until use for RNA isolation. Total RNA was isolated from Trizol according to the manufacturer's protocol. Isolated RNA was purified using the RNeasy ${ }^{\circledR}$ Mini Kit (Qiagen) together with DNAse treatment (RNAse-free DNAse provided by Qiagen) according to the manufacturer's recommendations. Quantity and purity of the RNA was determined spectrophotometrically. cDNA was prepared using the iScript ${ }^{\mathrm{TM}}$ CDNA Synthesis kit (BioRad, CA, USA). The HPRT cDNA was amplified by PCR, followed by DNA sequencing on a $\mathrm{ABI} 3700$ using a BigDye Terminator v1.1 cycle sequencing kit (Applied Biosciences) using the following overlapping primers: HPRT1 5'-CTT CCT CCT CCT GAG CAG TC-3'; HPRT2 5'-AAG CAG ATG GCC ACA GAA CT-3'; HPRT3 5'-CCT GGC GTC GTG ATT AGT G-3'; and HPRT4 5'-TTT ACT GGC GAT GTC AAT AGG A-3' [18].

\section{DNA isolation and ${ }^{32} P$-postlabeling of BPDE-DNA adducts}

To study possible differences in BPDE-DNA adduct removal, A549 cells stably expressing K63R-Ub or $W T-U b$ were exposed to $0.1 \mu \mathrm{M}$ BPDE. After $30 \mathrm{~min}$ of incubation at $37^{\circ} \mathrm{C}$, medium containing BPDE was replaced by fresh culture medium and cells were harvested after $0,1,8$, and $24 \mathrm{~h}$ of recovery. Cells were centrifuged at $1000 \mathrm{~g}$ and pellets were stored at $-20^{\circ} \mathrm{C}$ until DNA isolation. Standard phenol extraction was used to obtain genomic DNA [21]. ${ }^{32} \mathrm{P}$-postlabeling was carried out using the nuclease P1 enrichment technique as described by Reddy and Randerath with some modifications [21]. Briefly, an aliquot containing $10 \mu \mathrm{g}$ DNA was digested using micrococcal endonuclease $(0.25 \mathrm{U} / \mu \mathrm{L})$ and spleen phosphodiesterase (2 $\mu \mathrm{g} / \mu \mathrm{L}$ ) for 3.5 hours at $37^{\circ} \mathrm{C}$. Subsequently, DNA-digests were treated with nuclease P1 $(2.5 \mu \mathrm{g} / \mu \mathrm{L})$ for $30 \mathrm{~min}$ at $37^{\circ} \mathrm{C}$. To stop the NP1-reaction, $1 \mathrm{M}$ Tris $(\mathrm{pH}$ 9.6) was added. BPDE-modified nucleotides were subsequently labeled with $(\gamma-$ $\left.{ }^{32} \mathrm{P}\right)$ ATP $(50 \mu \mathrm{Ci} /$ sample; ICN, Indianapolis) using T4-polynucleotide kinase (10 $\mathrm{U} / \mu \mathrm{L}$ ) for $30 \mathrm{~min}$ at $37^{\circ} \mathrm{C}$. The radiolabelled adducted nucleotide biphosphates were separated on PEI-cellulose sheets (Machery Nagel, Düren, Germany) by multidirectional thin layer chromatography (TLC). In all experiments two BPDE-DNA standards with known adduct levels ( 1 adduct $/ 10^{7}$ and 1 adduct $/ 10^{8}$ nucleotides) were analyzed in parallel for quantification purposes. Quantification was performed using Phosphor-Imaging technology (Fujifilm FLA-3000).

Additionally, to asses the amount of DNA in the reaction, an aliquot of DNAdigest was diluted and labeled with $\left(\gamma_{-}{ }^{32} \mathrm{P}\right) \mathrm{ATP}$. Nucleotides were separated on a $\mathrm{PEI}$-cellulose sheet by one directional TLC in $0.12 \mathrm{M} \mathrm{NaH}_{2} \mathrm{PO}_{4}(\mathrm{pH} \mathrm{6)}$ for 5-6h. A dAP-standard were analyzed along with the other samples for quantitation purposes. 


\section{Western Blots}

To study PCNA poly-ubiquitination upon BPDE-exposure, immunoblotting techniques were carried out as described previously [18]. Briefly, A549 and HeLa cells were treated with BPDE for $1 \mathrm{~h}$ and lysed $5 \mathrm{~h}$ post-treatment $(20 \mathrm{mM}$ Tris- $\mathrm{HCl}$ [pH 7.5], $150 \mathrm{mM} \mathrm{NaCl}, 1 \%$ Triton-X-100, 2 mM EDTA, and 5\% glycerol with 200 $\mu \mathrm{g} / \mathrm{mL}$ phenylmethylsulfonyl fluoride, $2 \mathrm{mM} \mathrm{NaVO} 4,2 \mathrm{mM} \mathrm{NaF}$, and $2 \mathrm{mM} \mathrm{NaPPi}$ protease-inhibitor cocktail). Since, in our previous study UV was shown to induce poly-ubiquitination of PCNA [18], UV-irradiated cells $\left(30 \mathrm{~J} / \mathrm{m}^{2}\right)$ were used as a positive control. Samples were sonicated, soluble fractions were recovered, and proteins were quantified. Proteins were resolved on a single-phase 10\% SDSpolyacrylamide gel and electroblotted onto a Hybond $C$ nitrocellulose membrane (Amersham Pharmacia Biotech, Piscataway, New Jersey, United States). The following antibodies were used: rabbit polyclonal anti-Ub (Dako, Glostrup, Denmark), mouse monoclonal anti-PCNA PC10 (Chemicon, http://www.chemicon.com), and mouse monoclonal anti-actin as reference (Sigma). Proteins were visualized using SuperSignal West Pico Chemiluminescent Substrate (Pierce Biotechnology Rockford, Illinois, United States).

\section{Immunoprecipitations}

Immunoprecipitation of PCNA was performed as described previously [18]. In brief, cells were treated with BPDE as described above and harvested in lysis buffer. An anti-PCNA antibody was incubated overnight with $500 \mu \mathrm{g}$ of protein lysate. The following day, lysates were incubated with $100 \mu \mathrm{L}$ of Gamma-Bound Sepharose Beads (Amersham Pharmacia Biotech). After $48 \mathrm{~h}$ beads were washed extensively in lysis buffer, and proteins were eluted by boiling in Laemmli's SDS sample buffer. Immunoblotting was performed as described above except that the membranes were autoclaved for $20 \mathrm{~min}$ in $\mathrm{ddH}_{2} \mathrm{O}$ after protein transfer, and proteins were visualized as described above.

\section{GFP-POL $\eta$ foci formation}

A549 and HeLa cells stably expressing WT-Ub-puro and K63R-Ub-puro were grown on $35 \mathrm{~mm}$ glass bottom dishes (MatTek Corporation, Ashland, U.S.A) until $80 \%$ confluency. Plasmids expressing POLn-GFP fusion protein (a generous gift of Dr. Alan R. Lehmann, Genome Damage and Stability Centre, University of Sussex, Falmer, Brighton U.K.) were transfected into the cells using lipofectamine according to the manufacturer's protocol (Invitrogen Life Technologies, Carlsbad, California). After $24 \mathrm{~h}$ of incubation, POL $\eta$-GFP transfection efficiency was checked by fluorescence microscopy, and cells were exposed to 0.1 and $0.5 \mu \mathrm{M}$ BPDE for 30 $\min$ at $37^{\circ} \mathrm{C}$. Then $6 \mathrm{~h}$ post-incubation, cells expressing GFP-POL $\eta$ proteins were visualized using a live-cell microscopy unit mounted on a Leica DR IRBE inverted microscope, equipped with a polychromator that allows generation of light of the 


\section{Chapter 6}

required wavelength, using a $63 x$ magnification level. Both the polychromator and filterwheel were controlled via the PC using specialized Openlab software. To determine the percentage of cells with POL $\eta$ foci, only the POL $\eta$ expressing cells were evaluated. At least 100 cells were counted for each experimental condition by an experienced and blinded observer.

For co-localization studies, WT-Ub-puro and K63R-Ub-puro expressing A549 cells were transiently transfected with a POL $\eta$-GFP plasmid in a chamber slide (BD Biosciences Pharmingen). Cells were exposed to 0.1 and $0.5 \mu \mathrm{M}$ BPDE (30 min at $37^{\circ} \mathrm{C}$ ), 24 hours post-transfection. For detection of PCNA and POL $\eta$, cells were fixed in cold methanol for $20 \mathrm{~min}$ at $-20^{\circ} \mathrm{C}$ followed by $30 \mathrm{sec}$ in cold acetone to allow mild permeabilisation of the cells. Cells were washed twice with PBS and then incubated at room temperature with both anti-PCNA and anti-POL $\eta$ antibodies. After $1 \mathrm{~h}$, cells were washed with PBS and then incubated with Alexa 488-conjugated goat anti-rabbit IgG (Invitrogen) and Texas red-conjugated goat anti-mouse (Invitrogen) secondary antibodies for $\mathbf{4 5}$ min. After washing in PBS, cells were dehydrated for 1 min in $70 \%$ ethanol followed by two 1-min incubations in $100 \%$ ethanol. Cells were then mounted with Fluorescent Mounting Media (Dako) and visualized by two photon microscopy.

\section{Statistical analysis}

All data are presented as the mean \pm standard error of at least 2 independent experiments, unless stated otherwise. Differences in BPDE-DNA adduct removal and mutation frequencies between the different cell strains were analyzed by T-test. To examine differences in HPRT-mutation frequencies after exposure to various concentrations of BPDE versus the control ( $0 \mu \mathrm{M}$ BPDE), one-way ANOVA was used with subsequent Dunnett's-correction for multiple comparisons. A nonparametric Mann-Whitney test was performed to analyze differences in Pol $\eta$ foci formation between the two cell lines. Statistical analysis was performed using SPSS v.12.0.1. In each case, a difference was considered significant at $P<0.05$.

\section{Results}

\section{Disruption of K63-polyUb chain formation has no effect on the sensitivity of transfected A549 cells to BPDE}

To test the effect of disruption of K63-polyubiquitination on the sensitivity of transfected cells to BPDE, clonogenic survival assays were performed using a dose range from 0 to $1 \mu \mathrm{M}$ BPDE (Figure 1). We observed no statistical difference in the sensitivity of both cell lines to acute $(30 \mathrm{~min})$ treatment with BPDE. Similar observations were seen in mammalian [18] and yeast [15] cells demonstrating that expression of $K 63 R-U b$ does not affect the sensitivity towards UV. A possible explanation for the absence of a difference in sensitivity to acute BPDE exposure is 
that cells that are unable to form K63-polyUb chains can compensate for the loss of this pathway by utilizing the error-prone TLS arm of the DDT pathway. Therefore, these results suggest that inhibition of K63-polyUb chain formation does not sensitize cells to the toxic effect of BPDE indicating that WT-Ub and K63R-Ub expressing cells bypass BPDE-induced replication fork blockage with equal efficiency.

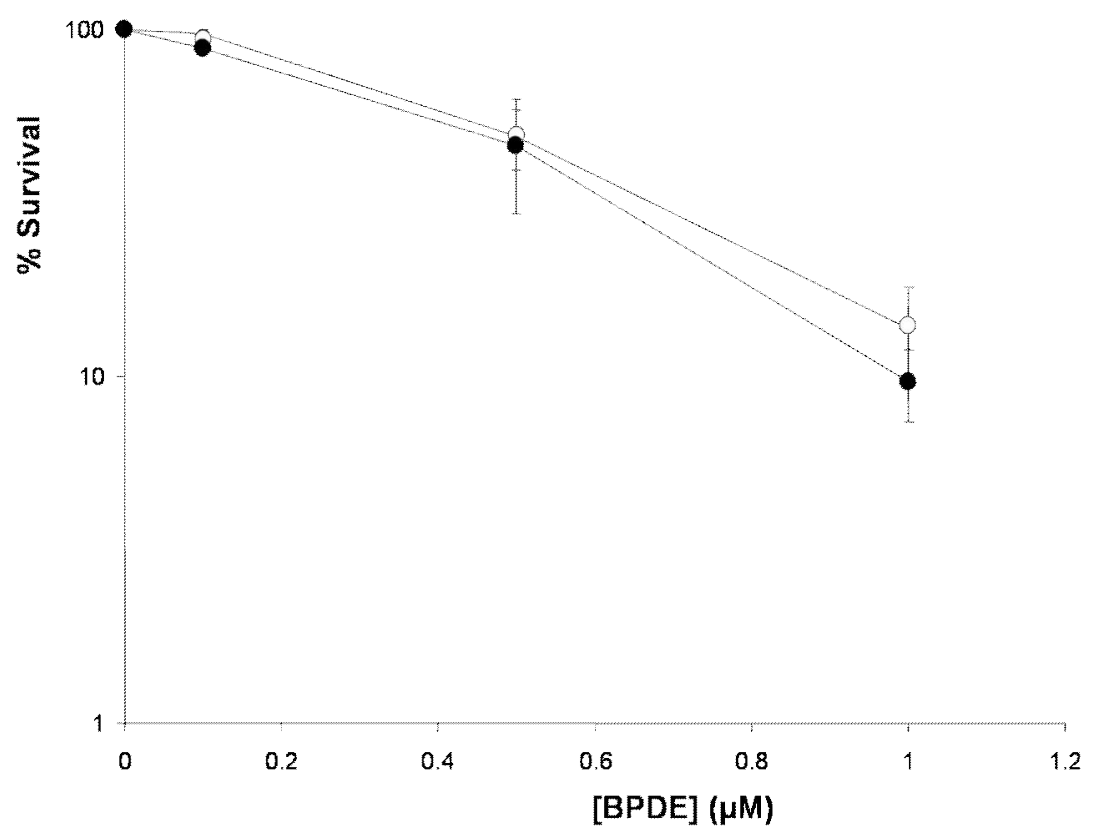

Figure 1. BPDE-induced cytotoxicity in A549 cells stably expressing K63R-Ub $(O)$ or $W T-U b(\mathbf{)})$. Cells were exposed for 30' to increasing concentrations of BPDE. Survival was evaluated by means of a clonogenic survival assay and expressed as the mean of three independent experiments ( \pm standard error).

\section{Disruption of K63-polyUb chain formation enhances BPDE-induced HPRT-mutations and induces a characteristic mutation spectrum}

To evaluate whether K63-polyUb chain disruption affects BPDE-induced mutagenesis, we determined the mutation frequency at the HPRT locus upon BPDE exposure. Following the correction for cell survival, A549 cells stably expressing $K 63 R-U b$ showed a dose dependent and significant increase in the frequency of HPRT-mutations ( 54, 87, 19 fold increase at exposure levels of $0.1,0.5$ and $1 \mu \mathrm{M}$ BPDE, respectively) as compared to their WT-Ub expressing counterparts (Figure 2). This increased BPDE-induced mutagenicity in the $K 63 R-U b$ expressing cells suggests that the formation of K63-polyUb chains is indeed a prerequisite for the error-free bypass of BPDE-DNA adducts. 


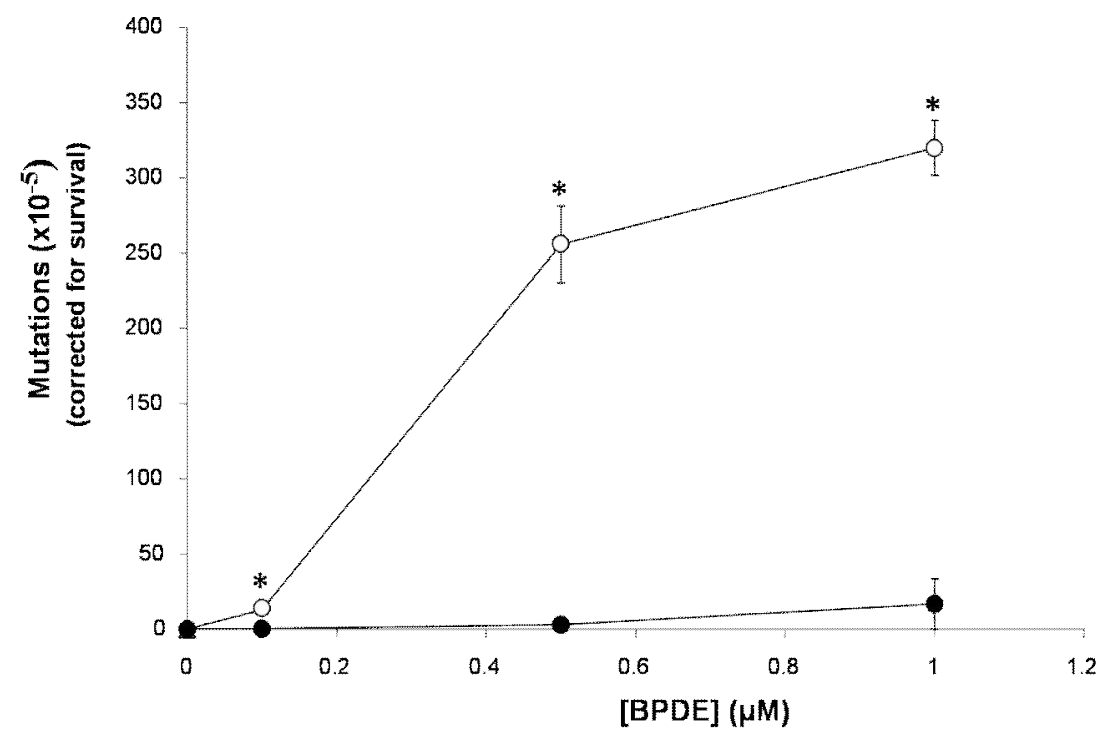

Figure 2. Effect of K63R-Ub expression on BPDE-induced mutagenicity. After exposure to BPDE, mutation frequencies at the HPRT gene were determined via selection in medium containing 6-TG. Mutations were corrected for survival and BPDE-induced mutation frequencies were obtained by subtracting the background frequencies, which were 0.59 and $10.37 \times 10^{-5}$ clonable cells for WT-Ub (O) and K63R-Ub (O) expressing cells respectively. The mean values of two independent experiments are shown with standard errors. ( ${ }^{*} \mathrm{P}<0.001, K 63 R-U b$ vs. $\left.W T-U b\right)$

Furthermore, we examined the spectrum of BPDE-induced mutations in individual clones of K63R-Ub expressing cells. Sister clones were excluded as only a single colony per treated population was isolated, as described above. Upon examination of the four overlapping sequences from each HPRT cDNA and removal of background mutations, 19 BPDE-induced mutations were found. $74 \%$ of these mutations were $G \rightarrow T$ transversions, while $G \rightarrow C$ transitions accounted for $21 \%$ (Table I). The large number of $G \rightarrow T$ mutations suggests that POL $\eta$ is the relevant mutagenic TLS polymerase (see Discussion). A single $T \rightarrow G$ mutation was unexpectedly observed suggesting that either the adenosine on the minus strand contained the BPDE-adduct, or more likely, the mutation occurred as a result of misincorporation directly following a guanine adduct (see Table I). Interestingly and in contrast to the previously reported UV-induced mutation spectra [18], most of the BPDE-induced base substitutions had the guanine adduct on the non-transcribed $(+)$ strand. These data are consistent with the mutation spectrum of BPDE-treated human fibroblasts or T-lymphocyte clones that were conducted in other studies $[22,23]$. Collectively, these data suggest that inhibition of K63-polyUb chain assembly results in an increased mutagenic effect of BPDE-exposure, indicating the involvement of error-prone TLS. 
Tabel I. BPDE-induced mutation spectrum in K63R-Ub expressing cells.

\begin{tabular}{|c|c|c|c|c|c|}
\hline Point mutations & Sequence change & Position (strand) & Amino acid & Mutant & $\%$ of Total \\
\hline$G>T$ & GATG $(G>T) T C A A$ & $472(+)$ & $\mathrm{Val} \rightarrow \mathrm{Phe}$ & 1 & \\
\hline $\mathrm{G}>\mathrm{T}$ & GACA $(G>T) G A C T$ & $134(+)$ & Arg $\rightarrow$ Met & 2 & \\
\hline $\mathrm{G}>\mathrm{T}$ & GGGG $(G>T) G C T A$ & $212(+)$ & Gly $\rightarrow$ Cys & 5 & \\
\hline$G>T$ & ACAG $(G->T) A C T G$ & $135(+)$ & Arg $\rightarrow$ Ser & 6 & \\
\hline$G>T$ & TGAT $(G>T) A A G G$ & $162(+)$ & Met $\rightarrow$ lle & 7 & \\
\hline $\mathrm{G}>\mathrm{T}$ & GATG $(G>T) T C A A$ & $472(+)$ & $\mathrm{Val} \rightarrow \mathrm{Phe}$ & 12 & \\
\hline $\mathrm{G}>\mathrm{T}$ & GTTG $(G>T) A T T T$ & $539(+)$ & $\mathrm{Gly} \rightarrow \mathrm{Val}$ & 13,2 & \\
\hline $\mathrm{G}>\mathrm{T}$ & TCAA $(G>T) G G G G$ & $207(+)$ & Lys $\rightarrow$ Asn & 14 & \\
\hline $\mathrm{G}>\mathrm{T}$ & GACT $(G>T) A A C G$ & $139(+)$ & Glu $\rightarrow$ STOP & 17 & \\
\hline $\mathrm{G}>\mathrm{T}$ & CAGG(G>T)ATTT & $601(+)$ & Asp $\rightarrow$ Tyr & 19 & \\
\hline $\mathrm{G}>\mathrm{T}$ & ACTG $(G>T) A A A G$ & $380(+)$ & $\mathrm{Gly} \rightarrow \mathrm{Val}$ & 20 & \\
\hline$G>T$ & $A C A G(G>T) G G A C$ & $335(+)$ & $\mathrm{Gly} \rightarrow \mathrm{Val}$ & 21,2 & \\
\hline $\mathrm{G}>\mathrm{T}$ & TCAA(G>T)GGGG & $207(+)$ & Lys $\rightarrow$ Asn & 24 & \\
\hline $\mathrm{G}>\mathrm{T}$ & AAGT(G>T)TTGG & $514(+)$ & $\mathrm{Val} \rightarrow$ Phe & 28 & 74 \\
\hline $\mathrm{G}>\mathrm{C}$ & $\mathrm{GAAC}(\mathrm{G}>\mathrm{C}) \mathrm{TCTT}$ & $143(+)$ & Arg $\rightarrow$ Pro & 10 & \\
\hline $\mathrm{G}>\mathrm{C}$ & TCAA $(\mathrm{G}>\mathrm{C}) \mathrm{GGGG}$ & $207(+)$ & Lys $\rightarrow$ Asn & 11 & \\
\hline $\mathrm{G}>\mathrm{C}$ & TAAT $(G>C) A C C A$ & $322(+)$ & Asp $\rightarrow \mathrm{His}$ & 13,1 & \\
\hline$G>C$ & GACT $(G>C) A A C G$ & $139(+)$ & $\mathrm{Glu} \rightarrow \mathrm{Gln}$ & 21,1 & 21 \\
\hline$T>G$ & $A A G G(T>G) C G C A$ & $479(+)$ & $\mathrm{Val} \rightarrow$ Gly & 4 & 5 \\
\hline
\end{tabular}

A549 cells stably expressing K63R-Ub were exposed to $0.5 \mu \mathrm{M}$ BPDE, further cultured for 7 days and then seeded in medium containing 6-TG. Single colonies were picked from each dish to ensure that no sister clones would be analyzed. The HPRT gene was then amplified by PCR followed by sequencing using four overlapping primers. The mutants are grouped by the type of observed point mutations.

\section{Disruption of K63-polyUb chain formation does not affect the occurrence and repair of BPDE DNA-adducts}

Mutagenicity of BPDE is directly related to the number of BPDE-DNA adducts in the cell $[22,24]$. Therefore, to exclude the possibility that the distinct mutagenic effects of BPDE in K63R-Ub versus WT-Ub transfected cells as described above, could be explained by either different initial BPDE-DNA adduct levels, or differences in timedependent adduct removal, we evaluated the kinetics of BPDE-DNA adduct levels over a period of 24 hours by ${ }^{32} \mathrm{P}$-postlabelling. Representative DNA adduct profiles of both A549 cell lines, acutely exposed to $0.1 \mu \mathrm{M}$ BPDE, are shown in Figure 3 (insert). For both the $W T-U b$ and K63R-Ub expressing cells, clear BPDE-dG spots were observed after a $30 \mathrm{~min}$ incubation period $(\mathrm{t}=0 \mathrm{~h})$. The intensity of the $( \pm)$-antiBPDE-dG spots rapidly reduced in time, indicating effective removal of the BPDEDNA adducts. Quantitative analysis revealed that the initial adduct level caused by acute treatment with $0.1 \mu \mathrm{M}$ was similar between both cell lines $(32.9 \pm 4.8$ and $31.6 \pm 6.9$ adducts $/ 10^{8}$ nucleotides for $W T-U b$ and $K 63 R-U b$ expressing cells, respectively). Moreover, no significant differences $(P>0.5)$ in removal of BPDE-DNA adducts were observed between A549 cells stably expressing K63R-Ub or WT-Ub (Figure 3). In both cell lines, DNA-adduct levels are reduced by $50 \%$ within $8 \mathrm{~h}$. To correct for possible dilution effects on DNA-adduct levels due to DNA synthesis 


\section{Chapter 6}

during cell replication, adduct levels were corrected for cell proliferation for each time point (\#cells at $t=$ recovery $/$ \#cells at $t=0 h$ ). Overall, these data suggest that the NER capacities of both A549 cell strains are comparable, and that NER is not affected by genetic modification of the Lys63-poly-ubiquitination process.

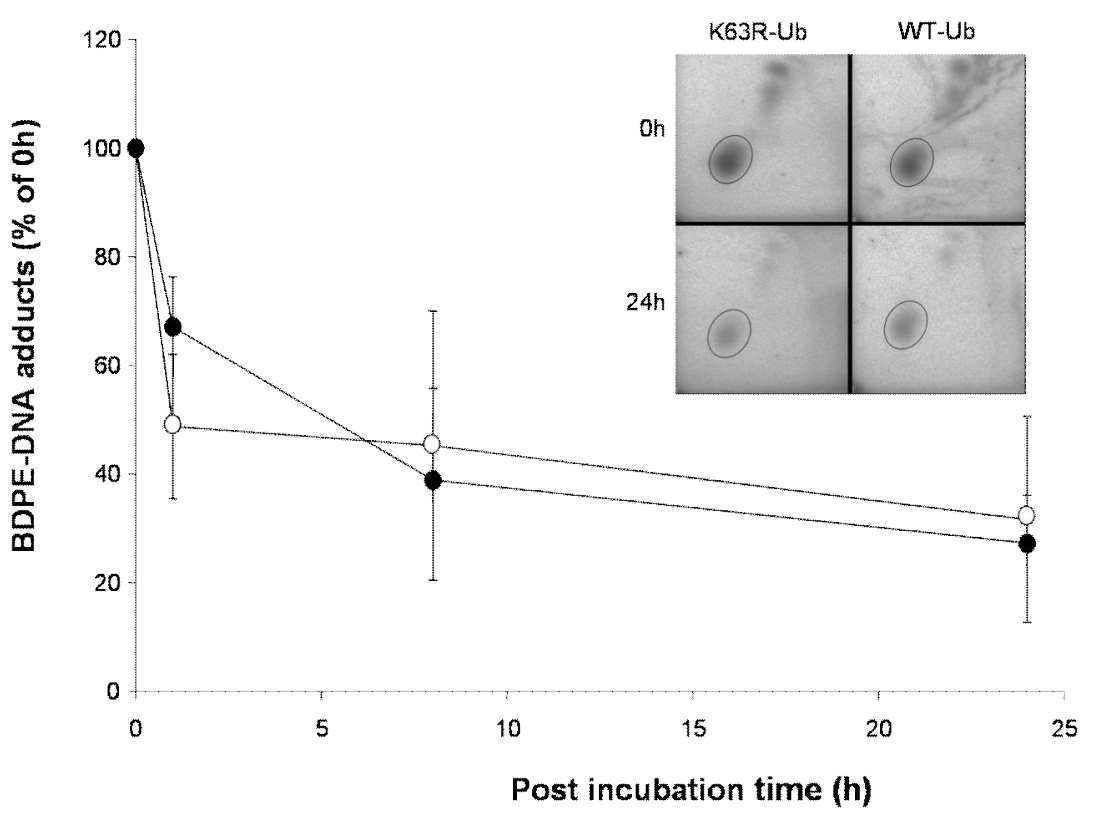

Figure 3. Removal of ( \pm )-anti-BPDE- $N^{2}-\mathrm{dG}$ adducts in $W T-U b(\mathbf{0})$ and K63R-Ub (O) expressing A549 cells after acute exposure to $0.1 \mu \mathrm{M}$ BPDE. Chromatograms of ${ }^{32} \mathrm{P}$ labeled BPDE-DNA adducts. A549 cell strains stably expressing K63R-Ub and WT-Ub show clear spots immediately after exposure to BPDE (Insert). After recovery of $24 \mathrm{~h}$ spot-intensities were reduced. Quantification was performed on the circled spots, which represent the ( \pm )-anti-BPDE- $N^{2}-d G$ adducts. ( \pm )-anti-BPDE-DNA adduct removal in A549 cells strains at various time intervals. Data are expressed as the mean adduct levels of two independent experiments ( \pm standard error).

\section{BPDE induces PCNA poly-ubiquitination}

Thus far our data support the idea that K63-linked ubiquitin chains are critical in the recovery of replication forks after the production of BPDE induced DNA damage. Based on our previous study [18], we postulated that the likely substrate of these chains is PCNA. Other studies have shown that BPDE exposure leads to monoubiquitination of PCNA [25] while PCNA poly-ubiquitination has not previously been reported. We investigated whether PCNA is poly-ubiquitinated in mammalian cells after BPDE treatment. Both A549 and HeLa cells were treated with 0.5 or $1 \mu \mathrm{M}$ BPDE or $30 \mathrm{~J} / \mathrm{m}^{2}$ UVB as a positive control. Five hours post-treatment, a prominent mono-ubiquitinated and a faint di-ubiquitinated band was observed in both UV and 
A
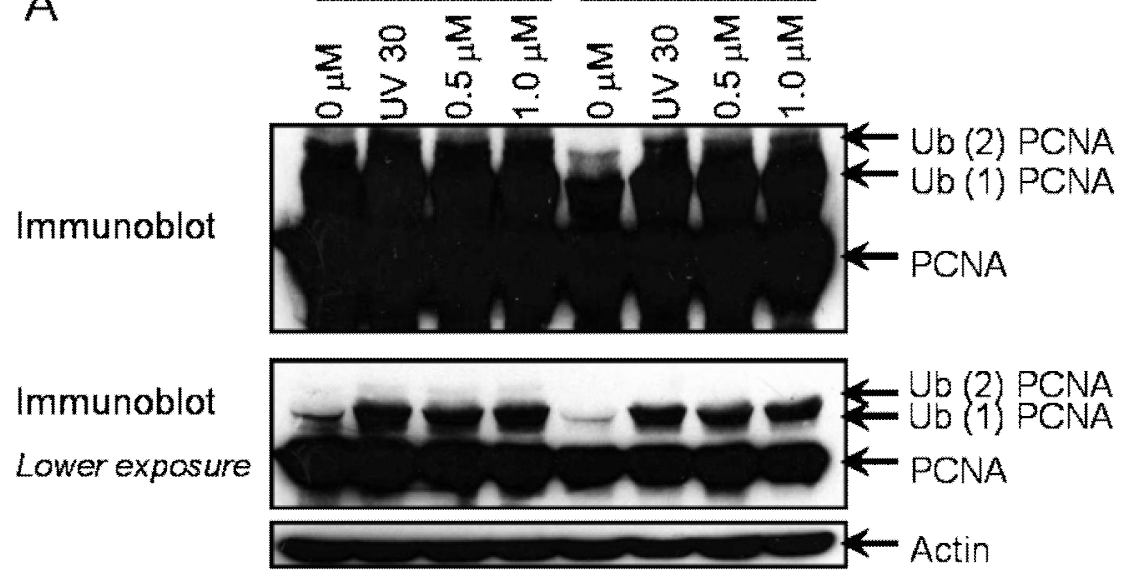

B
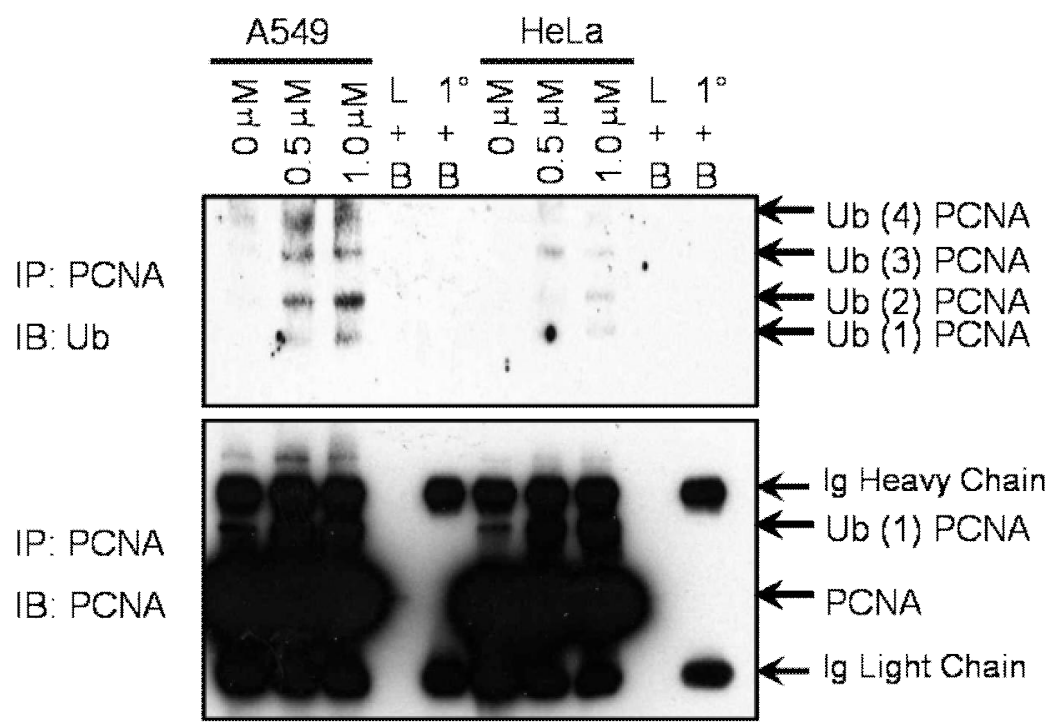

Figure 4. Poly-ubiquitination of PCNA upon UV- and BPDE-exposure. (A) Immunoblot form A549 and HeLa cells that were irradiated with $30 \mathrm{~J} / \mathrm{m}^{2} \mathrm{UV}$ or exposed to 0.5 and 1 $\mu \mathrm{M}$ BPDE. Cells were lysed $6 \mathrm{~h}$ post-treatment followed by immunoblotting for PCNA. A high and lower exposure of the PCNA immunoblot is shown. (B) A549 cells were exposed to BPDE and lysed in boiling SDS, diluted in lysis buffer and subjected to immunoprecipitation with a PCNA antibody and detected with PCNA or Ub antibodies. The controls in the immunoprecipitations were " $L+B$ ", in which lysates were incubated with beads but no PCNA antibody, and " $1^{\circ}+\mathrm{B}$ " in which PCNA antibody was incubated with beads alone. In the later case only the immunoglobulin heavy and light chains are detected on the immunoprecipitations. 


\section{Chapter 6}

BPDE treated cells (Figure 4A). In addition, over-exposure of this blot revealed a stronger higher molecular weight band corresponding to di-ubiquitinated PCNA. Similar to our previous report using UV light as a mode of DNA damage, it is often difficult to see more than a di-ubiquitinated form of PCNA on an immunoblot after DNA damage, which is a likely limitation of the antibody. In addition, we also see lower levels of mono- and di-Ub PCNA in our untreated cells. We postulate that this modification is a response to endogenous DNA damage.

Nevertheless, to confirm that these bands are indeed ubiquitinated PCNA, immunoprecipitation using an antibody directed against PCNA followed by immunoblotting with anti-ubiquitin was performed (Figure 4B). Several ubiquitinated species were observed corresponding to mono-, di-, tri- and tetra-ubiquitinated PCNA. This laddering pattern was similar to the banding pattern observed after UV irradiation from a previous study [18]. Taken together, our data suggest that PCNA is a target for poly-ubiquitination after BPDE-induced DNA damage, further supplementing the accumulating evidence that PCNA poly-ubiquitination is an important process in response to a variety of DNA lesions.

\section{Increased recruitment of POL $\eta$ to the replication fork upon blockage by BPDE}

To support our suggestion that the increased BPDE mutagenesis in the K63R-Ub expressing cells is brought about by the enhanced recruitment of error-prone $Y$ family polymerases, we analyzed the effects of K63R-Ub expression on POLn foci formation. We selected this particular TLS polymerase as previous reports suggest that it is the relevant polymerase responsible for the error-prone bypass of BPDEDNA adducts [9,11]. The previously described HeLa and A549 cells, expressing $W T-U b$ or K63R-Ub fused with the puromycin resistance gene were used and transfected with the POLn-GFP plasmid. No differences in transfection efficiency with POLn-GFP in both cell lines were observed (data not shown). Importantly, we previously showed that these cells behave identically to the ubiquitin GFP fusion expressing cells and that there were no overt defects in POL $\eta$ function [18]. In line with other similar studies [26], we observed homogenous nuclear expression of the POL $\eta$ protein in all transfected cells. Similar to previous reports [18,26-28], in the absence of BPDE, foci were observed in 17 and $22 \%$ of the HeLa cells (Figure $5 \mathrm{~A}$ ) and 14 and $15 \%$ of the A549 cells (Figure 5B) expressing WT-Ub or K63R-Ub respectively, showing no statistical differences between both cell lines. Within $6 \mathrm{~h}$ of exposure to 0.1 and $0.5 \mu \mathrm{M}$ BPDE, POL $\eta$ relocalized in distinct focal patterns in the nucleus (Figure 5C left). Upon exposure to $0.5 \mu \mathrm{M}$ BPDE, the percentage of cells with foci increased to $52.5 \%$ and $53.9 \%$ in HeLa and A549 cells expressing K63R$U b$, respectively (Figure 5A\&B). In HeLa and A549 cells stably expressing WT-Ub, the induction of POL $\eta$ foci was significantly less after BPDE-exposure $(20 \%$ and $25 \%$ at $0.5 \mu \mathrm{M}$ of BPDE for HeLa and A549 cells, respectively). Overall, our data show that inhibition of K63-linked poly-ubiquitination causes a $\sim 3$-fold increase in 
A

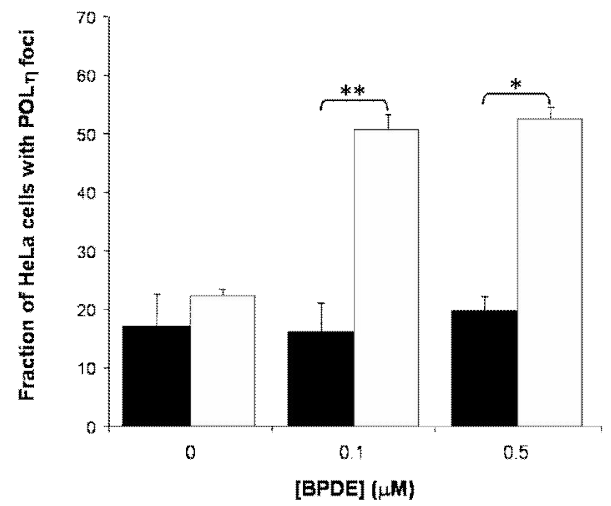

B

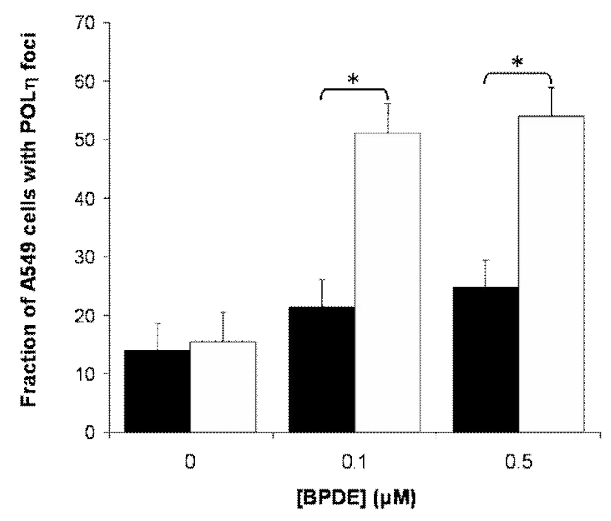

C

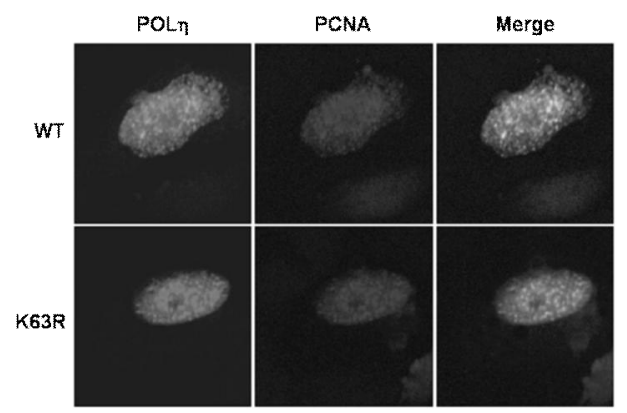

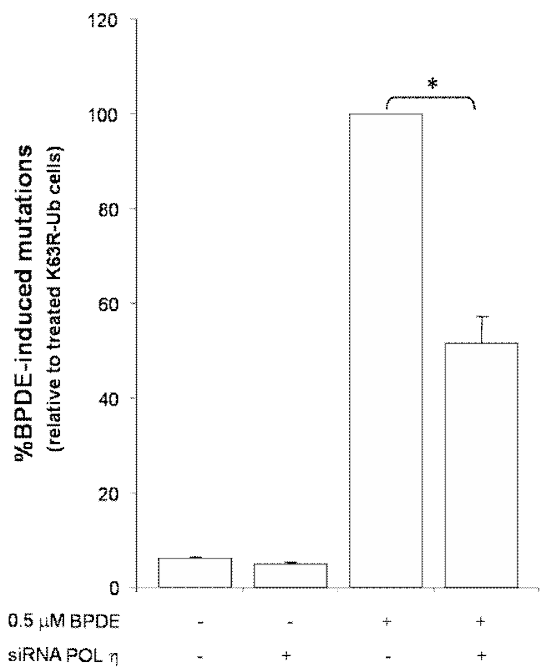

Figure 6. Effect of POL $\eta$ knockdown on BPDE-induced mutagenicity. The number of HPRT mutants was quantitated upon exposure to $0.5 \mu \mathrm{M}$ BPDE for A549 cells stably expressing K63R-Ub with or without POL $\eta$ RNAi. BPDE-induced mutations were corrected for the plating efficiency and presented as the percentages of the mutation frequency in the BPDE treated $K 63 R-U b$ expressing cells. The mean values of two independent experiments are shown with standard error $\left({ }^{*} \mathrm{P}<0.03\right.$, BPDE exposed cells with vs. without POL $\eta \mathrm{RNAi})$.

Figure 5. Relocalization of POL $\eta$ into intranuclear foci after BPDE-exposure. (A) HeLa cells $(n=4)$ and $(B)$ A549 cells $(n=2)$ stably expressing WT-Ub-puro $(\mathbf{\square})$ and K63R-Ubpuro $(\square)$ were transiently transfected with plasmids encoding GFP-POL $\eta$. 24h posttransfection, cells were exposed to 0.1 and $0.5 \mu \mathrm{M}$ BPDE for $30 \mathrm{~min}$ at $37^{\circ} \mathrm{C}$. Foci were quantified $6 \mathrm{~h}$ after treatment using a live-cell imaging microscope and percentages of cells with POL $\eta$ foci were calculated. The mean values of at least two independent experiments are shown with standard error $\left({ }^{* *} \mathrm{P}=0.02\right.$, ${ }^{*} \mathrm{P}<0.05 \mathrm{~K} 63 R-U b$ vs. WT-Ub for 0.1 and $0.5 \mu \mathrm{M}$ BPDE, respectively). (C) Representative confocal photographs showing a $100 \%$ co-localization of POL $\eta$ with PCNA in these A549 cells, $6 \mathrm{~h}$ after BPDEexposure. POL $\eta$ (green) and PCNA (red) were detected using antibodies. 


\section{Chapter 6}

$P O L \eta$ foci $(P<0.05)$ after acute exposure to BPDE. This increase parallels the enhanced mutation frequency in BPDE-treated K63R-Ub expressing cells (cf. Figure 2) suggesting the involvement of POL $\eta$ in BPDE-induced mutagenesis in the K63R$\mathrm{Ub}$ expressing cells. Furthermore, we also analyzed the co-localization of these foci with sites of DNA replication as revealed by positive PCNA foci. In both the WT-Ub and K63R-Ub expressing A549 cells, 100\% of the BPDE-induced POL $\eta$ foci colocalized with PCNA foci (Figure $5 \mathrm{C}$ ). This indicates that the foci produced in the $K 63 R-U b$ expressing cells are typical of those previously reported to occur at sites of blocked replication $[18,26]$.

\section{Knockdown of POL $\eta$ diminishes the mutagenicity of BPDE}

Collectively, our data suggest that inhibition of K63-polyUb chain assembly results in an increased requirement for TLS to bypass BPDE-DNA adducts (cf. Figure 5). To establish a possible causal role of POL $\eta$ in the increased mutagenicity of BPDE as observed in the K63R-Ub expressing cells, we suppressed the expression of POL $\eta$ in these cells by using siRNA. The combination of disrupting K63R-polyUb chain formation and POL $\eta$ knockdown resulted in a 50\% reduction in BPDE-induced HPRT mutations (Figure 6), indicating a predominant role of POL $\eta$ in error-prone bypass of BPDE lesions in the K63R-Ub expressing cells. 


\section{Discussion}

In the present study we showed that lysine 63-linked poly-ubiquitination is an important process to protect mammalian cells against BPDE-induced mutagenicity. This protective effect is distinct from TLS and is likely caused by directing DDT mechanisms into an error-free pathway, in which the information on the daughter strand is used to correctly circumvent the DNA lesion. This would suggest that K63poly-ubiquitination is a general requirement for physiological protection against mutagenesis in mammalian cells.

Stelter and Ulrich have shown that disruption of the error-free arm of DDT in yeast, as a consequence of a UBC13 mutation, results in a dramatic increase in UVinduced mutations [15]. Moreover, we recently reported that K63-linked polyubiquitination is required for error-free DDT in human cells as disruption of this specific chain formation leads to increased UV mutagenicity $[18,29]$. In the present study, K63-linked poly-ubiquitination was observed upon exposure to BPDE and inhibition of this polyUb chain formation resulted in up to 87-fold increase in BPDEinduced mutations in K63R-Ub compared to the $W T-U b$ expressing cells.

In a previous study we proposed a model in which K63-polyUb chains are suggested to activate an error-free mechanism that protects cells against UVinduced mutations that would otherwise be induced by error-prone TLS polymerases [18]. In this present study, we extend this model to include the bypass of BPDE-DNA lesions implying that the observed increased BPDE-induced mutation frequency in the $K 63 R-U b$ expressing cells would likely be caused by the bypass by low-fidelity and error-prone DNA polymerases. Previous reports have suggested that POL $\eta$ is the main polymerase responsible for the mutagenicity of BPDE-DNA adducts by predominantly inserting an adenosine opposite the BPDE- $N^{2}-\mathrm{dG}$ lesion, causing the characteristic $\mathrm{G} \rightarrow \mathrm{T}$ transversions [9]. Appropriately, the majority $(74 \%)$ of mutations observed in our model is also this $G \rightarrow T$ mutation supporting the idea that POL $\eta$ is the relevant enzyme for the bypass of BPDE-DNA adducts. Furthermore, intra-nuclear POL $\eta$ foci formation was $\sim 3$-fold increased in BPDEtreated K63R-Ub expressing cells, indicating the involvement of POL $\eta$ in the increased BPDE-induced mutagenic effects in absence of K63-linked polyubiquitination. In the HeLa and A549 cells stably expressing WT-Ub there was no clear induction of cells with POL $\eta$ foci after BPDE-exposure. This is in contrast with studies from Ogi et al. observing POL $\eta$ foci recruitment in $\sim 90 \%$ of the human lung fibroblast exposed to $20 \mu \mathrm{M}$ of $\mathrm{B}[\mathrm{a}] \mathrm{P}$ [27]. These contrasting observations are most likely explained by a significant difference in dosing strategies. In the present study POL $\eta$ foci were assessed $6 \mathrm{~h}$ post acute $(30 \mathrm{~min}$ ) BPDE treatment, while Ogi et al. quantitated foci following $16 \mathrm{~h}$ of continuous exposure to complete medium containing $\mathrm{B}[\mathrm{a}] \mathrm{P}$ and $\mathrm{S} 9 \mathrm{mix}$.

We observed POL $\eta$ foci to co-localize with the DNA polymerase clamp, PCNA. As this protein is required for replication, this suggests that POL $\eta$ is tightly associated with the replication machinery and is therefore locally available to carry 


\section{Chapter 6}

out TLS past the blocking lesions. Similar POL $\eta$ recruitment and co-localizations were observed in human fibroblasts [26,30] and human cancer cells lines [18] upon exposure to UV irradiation. Furthermore, we studied the effect of POL $\eta$ knockdown on the BPDE-induced mutation frequencies in the K63R-Ub expressing A549 cells, and found a $50 \%$ reduction in HPRT mutations. This further confirms that POL $\eta$ is a crucial component of the error-prone bypassing of replication stalling BPDE-DNA adducts in cells with suppressed K63-linked poly-ubiquitination.

The preferential insertion of adenosine by POL $\eta$ opposite $( \pm)$-anti-BPDE- $N^{2}-d G$ adducts will lead to the induction of G:C-to-T:A transversions [9]. This was indeed confirmed by analyzing the mutation spectrum in the BPDE-treated K63R-Ub expressing cells, showing predominantly $\mathrm{G} \rightarrow \mathrm{T}$ point mutations. An intriguing explanation for the increase in mutation frequency and the high proportion of G:Cto-T:A transversions is the relative resistance of especially the (+)-trans-anti-BPDE$N^{2}$-dG adducts to NER due to its minimal distortion of the helix [31]. As a consequence of this adduct being silent to NER, we predict that these adducts will persist over time and thus present as a substrate for POL $\eta$ mediated mutagenesis. Intriguingly, this would suggest that known helix deforming lesions such as those produced by UV light would be less mutagenic than BPDE. Indeed, UV induced mutation frequency in this model system was previously reported to be 2-fold increased [18] compared to 87-fold for $0.5 \mu \mathrm{M}$ BPDE. Since, UV-induced DNA lesions cause severe DNA-helix distortions that will be repaired faster by NER $[31,32]$, reliance on potentially mutagenic TLS-bypass processes during replication will be attenuated.

Interestingly, all observed $G \rightarrow T$ transversions were consistent with a BPDEguanine adduct on the non-transcribed (+) strand of the HPRT gene that was replicated inaccurately. As previously reported, this strand specificity indicates preferential repair of BPDE DNA-adducts in the transcribed strand, which is consistently faster than the repair of adducts in the non-transcribed strand [23,33]. The transcription coupled repair sub-pathway of NER is highly selective for adducts in the transcribed DNA strand [34,35], whereas repair of the non-transcribed strand will be dependent on DNA replication across these 'bulky' DNA adducts by TLS. This suggests that cells that contain lesions that are less amenable to NER would rely more on bypass by TLS as a means for survival. Interestingly, this would predict that lesions on the non-transcribed strand would persist and remain in the genome.

G:C-to-T:A transversions are also found in higher frequencies in lung cancers from smokers compared to non-smokers [36]. Moreover, others have shown a good correlation between hotspots of DNA adduct formation by PAHs, such as B[a]P, found in tobacco smoke and G:C-to-T:A transversion hotspots in lung cancer [37]. This higher prevalence of $\mathrm{G} \rightarrow \mathrm{T}$ transversions in lung cancer is generally interpreted as the primary mutagenic signature of PAH-DNA damage. As such, it would be of great interest to determine whether Lys63-polyUb chain formation has an etiological role in tobacco smoke-induced and PAH-mediated lung cancer. Studies of Sasaki et al. for instance [38], showed a link between lung cancer and the RAD6-dependent 
DDT mechanisms. They observed a decreased expression of the human homologue of yeast RAD6 (hRAD6B) in lung cancer, which might be a biomarker for decreased DDT capacity. Since, RAD6 is one of the key players in the enzymatic complex (RAD18, RAD5, UBC13/MMS2) that assembles the K63R-polyUb chains [14], this may suggest a link between pulmonary carcinogenesis and K63R-polyUb chain formation.

In conclusion, our data show that inhibition of Lys63-linked poly-ubiquitination of PCNA significantly enhances BPDE-induced mutations involving recruitment of the error-prone $\mathrm{Y}$-family polymerase POL $\eta$. We therefore propose that formation of K63-polyUb chains protects (BPDE-exposed) human cells against translesion synthesis-mediated mutagenesis, implying that ubiquitination guards against chemical carcinogenesis. This predicts that alterations in ubiquitination and the genes that control it may influence the susceptibility of individuals to environmental mutagenesis, and possibly carcinogenesis. For example, it has been demonstrated that oxidative stress modulates the ubiquitination process via reversible $S$ thiolation/dethiolation of E1 and E2 enzymes [39-41]. Such an effect could have major consequences for functioning of ubiquitin-conjugating enzymes (E2s), such as RAD6 and UBC13, and thus Lys63-linked poly-ubiquitination. Finally, a major challenge for future studies will be to further elucidate DDT pathways in humans and to appreciate their role in cancer development upon exposure to environmental xenobiotics. Such studies should reveal whether K63-polyUb chain formation could serve as a target for chemopreventive strategies.

\section{Acknowledgements}

We are thankful to the laboratory of Dr. Alan R. Lehmann (Genome Damage and Stability Centre, University of Sussex, Falmer, Brighton U.K.) for providing plasmids expressing POL $\eta$-GFP fusion protein. This work was partially supported by the Dutch Cancer Society (grant \# UM2002-2636). A.M. Knaapen was supported by a postdoctoral fellowship from the Netherlands Organisation for Scientific Research (NWO, grant 916.46.092). Furthermore, we thank Ralph W.H. Gottschalk for HPRT DNA sequencing and Kim Douma for two-photon fluorescence microscopy. 


\section{References}

1. Phillips D. H. Fifty years of benzo(a)pyrene. Nature 1983;303:468-472.

2. Peltonen K. and Dipple A. Polycyclic aromatic hydrocarbons: chemistry of DNA adduct formation. J Occup Environ Med 1995;37:52-58.

3. Cheng S. C., Hilton B. D., Roman J. M. and Dipple A. DNA adducts from carcinogenic and noncarcinogenic enantiomers of benzo[a]pyrene dihydrodiol epoxide. Chem Res Toxicol 1989;2:334-340.

4. Moriya M., Spiegel S., Fernandes A., Amin S., Liu T., Geacintov N. and Grollman A. $P$. Fidelity of translesional synthesis past benzo[a]pyrene diol epoxide-2'deoxyguanosine DNA adducts: marked effects of host cell, sequence context, and chirality. Biochemistry 1996;35:16646-16651.

5. Broomfield S., Hryciw T. and Xiao W. DNA postreplication repair and mutagenesis in Saccharomyces cerevisiae. Mutat Res 2001;486:167-184.

6. Wang Z. DNA damage-induced mutagenesis : a novel target for cancer prevention. Mol Interv 2001;1:269-281.

7. Friedberg E. C., Lehmann A. R. and Fuchs R. P. Trading places: how do DNA polymerases switch during translesion DNA synthesis? Mol Cell 2005;18:499-505.

8. Ogi T., Shinkai Y., Tanaka K. and Ohmori H. Polkappa protects mammalian cells against the lethal and mutagenic effects of benzo[a]pyrene. Proc Natl Acad Sci U S A 2002;99:15548-15553.

9. Zhang Y., Wu X., Guo D., Rechkoblit O., Geacintov N. E. and Wang Z. Two-step error-prone bypass of the (+)- and (-)-trans-anti-BPDE-N2-dG adducts by human DNA polymerases eta and kappa. Mutat Res 2002;510:23-35.

10. Lehmann A. R. Replication of damaged DNA by translesion synthesis in human cells. FEBS Lett 2005;579:873-876.

11. Rechkoblit O., Zhang Y., Guo D., Wang Z., Amin S., Krzeminsky J., Louneva N. and Geacintov N. E. trans-Lesion synthesis past bulky benzo[a]pyrene diol epoxide N2-dG and N6-dA lesions catalyzed by DNA bypass polymerases. J Biol Chem 2002;277:30488-30494.

12. Hoege C., Pfander B., Moldovan G. L., Pyrowolakis G. and Jentsch S. RAD6dependent DNA repair is linked to modification of PCNA by ubiquitin and SUMO. Nature 2002;419:135-141.

13. Hofmann R. M. and Pickart C. M. Noncanonical MMS2-encoded ubiquitinconjugating enzyme functions in assembly of novel polyubiquitin chains for DNA repair. Cell 1999;96:645-653.

14. Spence J., Sadis S., Haas A. L. and Finley D. A ubiquitin mutant with specific defects in DNA repair and multiubiquitination. Mol Cell Biol 1995;15:1265-1273.

15. Stelter P. and Ulrich H. D. Control of spontaneous and damage-induced mutagenesis by SUMO and ubiquitin conjugation. Nature 2003;425:188-191.

16. Leach C. A. and Michael W. M. Ubiquitin/SUMO modification of PCNA promotes replication fork progression in Xenopus laevis egg extracts. $J$ Cell Biol 2005;171:947-954.

17. Kannouche P. L., Wing J. and Lehmann A. R. Interaction of human DNA polymerase eta with monoubiquitinated PCNA: a possible mechanism for the polymerase switch in response to DNA damage. Mol Cell 2004;14:491-500.

18. Chiu R. K., Brun J., Ramaekers C., Theys J., Weng L., Lambin P., Gray D. A. and Wouters B. G. Lysine 63-polyubiquitination guards against translesion synthesisinduced mutations. PLoS Genet 2006;2:e116.

19. Tsirigotis M., Zhang M., Chiu R. K., Wouters B. G. and Gray D. A. Sensitivity of mammalian cells expressing mutant ubiquitin to protein-damaging agents. $J$ Biol Chem 2001;276:46073-46078.

20. van Schooten F. J., Hillebrand M. J., Scherer E., den Engelse L. and Kriek E. Immunocytochemical visualization of DNA adducts in mouse tissues and human 
white blood cells following treatment with benzo[a]pyrene or its diol epoxide. A quantitative approach. Carcinogenesis 1991;12:427-433.

21. Godschalk R. W., Maas L. M., Van Zandwijk N., van 't Veer L. J., Breedijk A., Borm P. J., Verhaert J., Kleinjans J. C. and van Schooten F. J. Differences in aromaticDNA adduct levels between alveolar macrophages and subpopulations of white blood cells from smokers. Carcinogenesis 1998;19:819-825.

22. Li Z., Zhang H., McManus T. P., McCormick J. J., Lawrence C. W. and Maher V. M. hREV3 is essential for error-prone translesion synthesis past UV or benzo[a]pyrene diol epoxide-induced DNA lesions in human fibroblasts. Mutat Res 2002;510:71-80.

23. Andersson B., Falt S. and Lambert B. Strand specificity for mutations induced by (+)-anti BPDE in the hprt gene in human T-lymphocytes. Mutat Res 1992;269:129140.

24. McGregor W. G., Wei D., Chen R. H., Maher V. M. and McCormick J. J. Relationship between adduct formation, rates of excision repair and the cytotoxic and mutagenic effects of structurally-related polycyclic aromatic carcinogens. Mutat Res 1997;376:143-152.

25. Bi X., Barkley L. R., Slater D. M., Tateishi S., Yamaizumi M., Ohmori H. and Vaziri C. Rad18 regulates DNA polymerase kappa and is required for recovery from Sphase checkpoint-mediated arrest. Mol Cell Biol 2006;26:3527-3540.

26. Kannouche P., Broughton B. C., Volker M., Hanaoka F., Mullenders L. H. and Lehmann A. R. Domain structure, localization, and function of DNA polymerase eta, defective in xeroderma pigmentosum variant cells. Genes Dev 2001;15:158-172.

27. Ogi T., Kannouche P. and Lehmann A. R. Localisation of human Y-family DNA polymerase kappa: relationship to PCNA foci. J Cell Sci 2005;118:129-136.

28. Bi X., Slater D. M., Ohmori H. and Vaziri C. DNA polymerase kappa is specifically required for recovery from the benzo[a]pyrene-dihydrodiol epoxide (BPDE)-induced S-phase checkpoint. J Biol Chem 2005;280:22343-22355.

29. Li Z., Xiao W., McCormick J. J. and Maher V. M. Identification of a protein essential for a major pathway used by human cells to avoid UV- induced DNA damage. Proc Natl Acad Sci U S A 2002;99:4459-4464.

30. Watanabe K., Tateishi S., Kawasuji M., Tsurimoto T., Inoue H. and Yamaizumi M. Rad18 guides poleta to replication stalling sites through physical interaction and PCNA monoubiquitination. Embo J 2004;23:3886-3896.

31. Hess M. T., Gunz D., Luneva N., Geacintov N. E. and Naegeli H. Base pair conformation-dependent excision of benzo[a]pyrene diol epoxide-guanine adducts by human nucleotide excision repair enzymes. Mol Cell Biol 1997;17:7069-7076.

32. Luch A. Nature and nurture - lessons from chemical carcinogenesis. Nat Rev Cancer 2005;5:113-125.

33. Denissenko M. F., Pao A., Pfeifer G. P. and Tang M. Slow repair of bulky DNA adducts along the nontranscribed strand of the human p53 gene may explain the strand bias of transversion mutations in cancers. Oncogene 1998;16:1241-1247.

34. Hanawalt P. C., Donahue B. A. and Sweder K. S. Repair and transcription. Collision or collusion? Curr Biol 1994;4:518-521.

35. Mitchell J. R., Hoeijmakers J. H. and Niedernhofer L. J. Divide and conquer: nucleotide excision repair battles cancer and ageing. Curr Opin Cell Biol 2003;15:232-240.

36. Le Calvez F., Mukeria A., Hunt J. D., Kelm O., Hung R. J., Taniere P., Brennan P., Boffetta P., Zaridze D. G. and Hainaut P. TP53 and KRAS mutation load and types in lung cancers in relation to tobacco smoke: distinct patterns in never, former, and current smokers. Cancer Res 2005;65:5076-5083.

37. Denissenko M. F., Pao A., Tang M. and Pfeifer G. P. Preferential formation of benzo[a]pyrene adducts at lung cancer mutational hotspots in P53. Science 1996;274:430-432. 


\section{Chapter 6}

38. Sasaki H., Moriyama S., Nakashima Y., Yukiue H., Fukai I. and Fujii Y. Decreased Hrad6B expression in lung cancer. Acta Oncol 2004;43:585-589.

39. Jahngen-Hodge J., Obin M. S., Gong X., Shang F., Nowell T. R., Jr., Gong J., Abasi H., Blumberg J. and Taylor A. Regulation of ubiquitin-conjugating enzymes by glutathione following oxidative stress. J Biol Chem 1997;272:28218-28226.

40. Obin M., Shang F., Gong X., Handelman G., Blumberg J. and Taylor A. Redox regulation of ubiquitin-conjugating enzymes: mechanistic insights using the thiolspecific oxidant diamide. Faseb J 1998;12:561-569.

41. Berlett B. S. and Stadtman E. R. Protein oxidation in aging, disease, and oxidative stress. J Biol Chem 1997;272:20313-20316. 




\section{Chapter 7}

\section{Summary and General Discussion}




\section{Chapter 7}

All living organisms are daily exposed to a variety of potentially harmful agents that originate from the environment, diet or even endogenous processes, which can damage cellular DNA. If damages to DNA remain unrepaired, these lesions may ultimately result in mutations that can lead to aberrant expression or function of gene products and subsequent initiation of diseases like cancer. Although, DNA damages occur in our body at relatively high frequencies each day, the incidence of mutations is in comparison low, which is due to the wide range of DNA repair mechanisms that organisms possess to maintain the integrity of their genome. Thus, DNA repair processes play a crucial role in the prevention of carcinogenesis. Humans possess several routes to repair damaged DNA, including nucleotide excision repair (NER) and base excision repair (BER) [1,2].

Since DNA repair is one of the steps that can intervene between DNA damage and the onset of carcinogenesis, it might be a relevant biomarker in the assessment of individual cancer risks. However, we first needed to gather more information on the intra- and inter-individual variations in DNA repair capacity in a healthy human population. These phenotypic variations are partly due to polymorphisms in DNA repair genes that may result in significant differences in repair enzyme synthesis or activity. Furthermore, other factors like exposure to environmental carcinogens or endogenous agents can have a major influence on DNA repair. Especially the modulation of DNA repair by nutrition and dietary compounds should be investigated. Moreover, in vitro as well as in vivo studies suggest that modulation of the redox status may alter DNA repair capacity, involving up- or down-regulation of enzymes that play a role in repair processes. Since the cellular redox status can be modulated by pro-oxidants and dietary antioxidants, the aim of the present thesis was to investigate the effect of nutritional redox modulation on the phenotypic NER capacity. In order to investigate the impact of nutritional factors on the NER capacity simple and reliable approaches to phenotypically assess NER in samples from population studies are needed.

Several approaches to determine DNA repair have been described in the past, which are largely based on treatment of live cells with damaging agents and subsequent monitoring of damage removal in time [desribed in Chapter 1]. The major limitation of such assays is that they are time-consuming and require freshly isolated cells or cells that need to be handled in such a way that their survival after cryopreservation is assured. Alternative approaches are the in vitro repair assays that depend on the incubation of a cell extract with a DNA substrate containing specific lesions. These methods are generally more sensitive and suitable for detecting DNA repair responses in frozen samples, such as human lymphocytes. Recently, Collins et al. developed such an in vitro repair assay based on the singlecell gel electrophoresis (comet) assay, to measure phenotypical differences in BER [3]. This alternative approach measures the capacity of human lymphocyte extracts to perform the initial steps of BER, i.e. damage recognition and incision, on DNA substrates carrying 8-oxoguanine lesions. However, up to now there were to the best of our knowledge only a few comet-based assays to measure NER. Still, many human 
cancers are directly related to exposure to environmental chemicals like polycyclic aromatic hydrocarbons (PAH) that exert their carcinogenic action through formation of bulky-DNA adducts which are generally removed by NER. Therefore, a modified comet assay was developed to phenotypically assess inter-individual differences in nucleotide excision repair capacities, as described in Chapter 2 of this thesis. In this repair assay the DNA substrate consist of gel-embedded nucleoids that were treated with ( \pm )-anti-benzo[a]pyrene-7,8-dihydrodiol-9,10-epoxide (BPDE) after cell lysis to induce BPDE-DNA adducts, which are a known substrate for NER. Incubation of these substrate nucleoids with cell extracts will allow the initial steps of NER to occur, i.e. damage recognition and incision, resulting in single strand breaks that can be detected by the comet assay. The rate at which breaks accumulate is indicative for the DNA repair capacity in the cell extracts (see Figure 1 of Chapter 2). Extracts from $X P A^{-/}$and $X P C^{-/}$fibroblasts (deficient in the proteins needed for the initial steps of NER) were used to validate this assay. Furthermore, human lymphocyte extracts showed significant variations in their DNA repair capacity, which seemed to correlate with the removal of bulky DNA lesions in the same cells over a period of 48 hours determined by ${ }^{32} \mathrm{P}$-postlabeling. Inter-individual variations in NER capacity measured by our assay were in the range of $\sim 8$-fold. Similar variations of $\sim 10$-fold were observed in human lymphocytes by Gaivao et al., conducting an alternative in vitro NER assay that uses nucleoid DNA containing UVinduced lesions [4]. These are relatively wide variations in NER capacity compared with inter-individual variations for BER that were reported to be approximately $\sim 4$ fold [4]. Notably, some individuals even appear to have negligible NER capacity as measured by comet-based in vitro repair assays, which might lead to an accumulation of DNA lesions after exposure to genotoxic agents, and a subsequent increased risk of mutations and cancer development. However, on the other hand, a lower NER capacity might also reflect the absence of lesions, because DNA damage can activate NER proteins directly via feedback control mechanisms. It is therefore necessary to assess DNA repair activity in combination with exposure (for example by using biomarkers of exposure) to be able to make reliable predictions on cancer susceptibility and risk. Nonetheless, it can be considered that impairment of DNA repair processes will lead to increased risks of pathological diseases like cancer. Overall, this newly developed assay is reliable, reproducible and can be used on frozen or freshly isolated lymphocytes, indicating its applicability in molecular epidemiological studies.

Our NER assay was first applied in an in vitro study as an attempt to investigate the influence of dietary factors on DNA repair. Although, there is some evidence that low intake of certain nutrients may affect DNA repair (reviewed in [5]), the molecular mechanisms through which diet can modulate this process are still unclear. One of the possible mechanisms is the modulation of the cellular redox status by dietary compounds, which can affect DNA repair processes. The formation of free radicals, like reactive oxygen species (ROS), is known to decrease the cellular redox status, leading to a state of oxidative stress. On the other hand, dietary antioxidants may 


\section{Chapter 7}

prevent/reduce oxidative stress through the scavenging of ROS or by stimulating endogenous defences. Furthermore, previous investigations have shown the involvement of free radicals in both the initiation and promotion of carcinogenesis $[6,7]$, and in vitro as well as in vivo studies have reported the importance of a balance between oxidants and antioxidants for the proper functioning of DNA repair, including NER [8,9]. Therefore, the aim of the in vitro study that is described in Chapter 3 was to obtain further insight in the relation between oxidative stress and nucleotide excision repair, both at the transcription and protein level. To modify the intracellular oxidative stress, we used non-cytotoxic doses of hydrogen peroxide $\left(\mathrm{H}_{2} \mathrm{O}_{2}\right)$ and $\mathrm{D}$,L-buthione-S,R-sulfoximine (BSO) to deplete the cellular antioxidant glutathione (GSH). To study the effect of oxidative stress on gene expression, we specifically selected genes that encode NER proteins involved in the recognition and incision steps of the repair process, because these phases are reflected in our NER capacity assay. The expression of most of the selected NER-related genes was up-regulated upon exposure to $\mathrm{H}_{2} \mathrm{O}_{2}$. This could be due to the fact that expression of many genes involved in cellular defence is controlled by redoxsensitive transcription factors such as AP-1. However, the expression of ERCC1, which was also reported to have an AP-1 binding sequence in the promoter region, was significantly down-regulated by $\mathrm{H}_{2} \mathrm{O}_{2}$. Though, Fratelli et al. showed that the expression of the AP-1 subunits, Fos and FosB, was not induced by $\mathrm{H}_{2} \mathrm{O}_{2}$ alone, but was strongly induced in GSH depleted cells [10]. Therefore, the restoration of ERCC1 expression that was seen in our study in GSH depleted cells exposed to $\mathrm{H}_{2} \mathrm{O}_{2}$ may partly be explained by activation of this transcription factor. These findings suggest that GSH has a signalling role in the redox-regulated gene expression of NER genes, but further studies are needed to verify these results and to understand the underlying molecular mechanisms.

Since most of the selected NER genes showed an increased expression upon exposure to $\mathrm{H}_{2} \mathrm{O}_{2}$, NER capacity as measured by our repair assay was expected to increase as well. However, an acute inhibition of NER capacity was seen after exposure to $\mathrm{H}_{2} \mathrm{O}_{2}$, which significantly correlated with the ERCC1 gene expression $(\mathrm{R} 2=0.85, \mathrm{p}<0.01)$. The observed inhibition of $\mathrm{NER}$ by $\mathrm{H}_{2} \mathrm{O}_{2}$ in our study, was in line with research from $\mathrm{Hu}$ et al. [8]. Further support for these observations comes from studies showing that lipid peroxidation products (e.g. 4-hydroxynonenal, malondialdehyde) can be potent inhibitors of NER, most likely by direct oxidative attack and inactivation of NER proteins [11-13]. Moreover, our in vitro observations in Chapter 3 were confirmed in a subsequent in vivo study that is described in Chapter 4. Iron-induced oxidative stress in newborn piglets, monitored as increased levels of 8-oxo-7,8-dihydro-2'-deoxyguanosine (8-oxodG) in colon tissue DNA and in urine, lead to a $70 \%$ reduction of the NER capacity. Since dietary antioxidants can modulate the redox status by acting as scavengers of ROS and lipid peroxidation products, we proposed that the inhibiting effects of oxidative stress on DNA repair could be compensated for by antioxidant rich supplementation. Indeed, in this in vivo study, supplementation of mother sows with an antioxidant enriched diet 
seemed to partly compensate the oxidative stress-induced reduction of the NER capacity in colon tissues of their offspring. The phenotypic NER capacity was significantly less reduced by oxidative stress in the supplemented group compared to the unsupplemented animals (reduced with $30 \%$ in stead of $70 \%$, respectively). Thus, dietary interventions could guard against the oxidative stress-induced deleterious effects by protecting nucleotide excision repair processes that maintain the integrity of the genome.

Therefore, based on our previous observations, we speculated that enhanced intake of antioxidants may be a candidate to improve NER in humans as well, possibly in combination with single nucleotide polymorphisms (SNPs) in repair genes that were also found to have an influence on DNA repair capacities. Therefore, Chapter 5 of this thesis describes a human intervention study in which the effects of dietary antioxidant intake, genetic polymorphisms in NER genes, and possible interactions between both on the phenotypically assessed NER capacity were investigated. Samples from 168 healthy volunteers consuming $1 \mathrm{~L}$ blueberry/apple juice per day were collected before and after a four week intervention period. All subjects were genotyped for 11 SNPs in NER related genes, using Multiplex PCR amplification plus a single base extension (SBE) based method, which was developed at our laboratory for this particular study. Based on the resulting genotype frequencies, a subpopulation of 36 healthy volunteers was selected for the phenotypical assessment of NER. Since, we previously observed a significant correlation between NER capacity and ERCC1 gene expression [Chapter 3] and because other studies also reported a positive correlation between repair capacity and ERCC1 expression [14-16], the selection of subjects occurred according to their ERCC1 genotype. However, in the intervention study depicted in Chapter 5, we did not observe any significant associations of the studied ERCC1 polymorphisms and the NER capacity. Since, inconsistent results have been reported before in scientific literature $[17,18]$, the functional relevance of SNPs in ERCC1 remains unclear. The common genetic polymorphism XPA-A23G did show significant correlations with the NER capacity in our human intervention study, with carriers of the XPA-GG genotype showing a $\sim 3$-fold higher NER capacity compared to homozygous wild-type and heterozygous subjects. Since these associations were not affected by the dietary intervention, XPA-A23G seems to be a good predictor for the NER capacity as assessed by our in vitro NER assay. Furthermore, the effect of the four week intervention with antioxidant rich blueberry/apple juice on the phenotypic NER capacity was evaluated and possible genotype-diet interactions were studied. Although, this intervention was found to be efficient in enhancing antioxidant defence and reducing ex vivo induced oxidative DNA damages [19,20], we did not observe a general effect of the dietary intervention on the NER capacity [Chapter 5]. However, carriers of variant/risk alleles of XPC-K939Q and RAD23BA249V seemed to benefit from the intervention, showing increased NER capacities after the intervention, which was not observed in their homozygous wild-type counterparts. As such, our results support the hypothesis that genetic 


\section{Chapter 7}

polymorphisms significantly affect the phenotypic DNA repair capacity, which can be further modulated by diet. However, the effect of diet seems to play a minor role as compared to the effects of genetic variation.

Although, the underlying mechanisms still remain unclear, a reduction in repair capacity during diseases involving oxidative stress might contribute to mutagenesis and carcinogenesis. For instance, chronic lung inflammatory diseases, such as sarcoidosis, fibrosis and chronic obstructive pulmonary disease (COPD), are characterized by the influx of polymorphonuclear neutrophils (PMNs) that produce and release ROS [21,22], leading to a chronic imbalance between oxidants and antioxidants. These PMNs have been demonstrated to be potent inhibitors of NER in human pulmonary epithelial cells, providing a possible biological explanation for the association between inflammation and lung cancer development [23]. Though, in such situations of chronic oxidative stress, less efficient repair can lead to persistence and accumulation of DNA lesions, which might block the progression of the replication fork. To avoid collapsing of the DNA replication fork and subsequent formation of double strand breaks upon such a blockage, cells possess DNA damage tolerance (DDT) systems to circumvent the damage and continue replication in the presence of lesions [24,25]. There are two known DDT pathways in eukaryotes, namely the damage avoidance pathway and translesion synthesis (TLS). The later comprises low fidelity translesion polymerases (e.g. Pol $\eta$, Pol $\kappa$, $\mathrm{Pol} \zeta$ ) that replace the replicative DNA polymerase (Pol $\delta$ or Pol $\varepsilon$ ), incorporating the correct or incorrect nucleotide opposite the lesion, depending on the involved TLS polymerase and the type of DNA damage. Since TLS polymerases directly copy the damaged DNA template, often in an error-prone way, it can cause mutations and contribute to carcinogenesis. In contrast to TLS, the damage avoidance pathway uses the information of the undamaged sister duplex at the replication fork, bypassing the lesion in an error-free way. Although its mechanism is yet unclear, it is suggested to involve template switching and might share some features with homologous recombination. Studies in yeast have shown that modification of the polymerase clamp proliferating cell nuclear antigen (PCNA) with lysine 63-linked poly-ubiquitin chains promotes the bypass of DNA lesions and determines if the bypass occurs via the error-free damage avoidance pathway or the error-prone TLS [26-28]. In Chapter 6 we show that PCNA is also poly-ubiquitinated in human pulmonary epithelial cells (A549 cells) upon exposure to benzo[a]pyrene-7,8dihydrodiol-9,10-epoxide (BPDE) and that disruption of this lysine 63-linked polyubiquitin chain formation enhances BPDE-induced mutagenicity, likely involving increased recruitment of the TLS polymerase Pol $\eta$. Previous reports have suggested that Pol $\eta$ is the main polymerase responsible for the mutagenicity of BPDE-DNA adducts by predominantly inserting an adenosine opposite the BPDE$N^{2}$-dG lesion, causing the characteristic $G \rightarrow T$ transversions [29]. Indeed in our study, the recruitment and co-localization of Pol $\eta$ with PCNA was enhanced upon exposure to BPDE, leading predominantly (74\%) to $G \rightarrow T$ mutations. As such, we suggest that lysine 63-linked poly-ubiquitination of PCNA is an important process to 
protect mammalian cells against BPDE-induced mutagenicity, directing DDT mechanisms into the error-free damage avoidance pathway. Therefore, we imply that the formation of these specific poly-ubiquitin chains as a general requirement for physiological protection against mutagenesis and chemical carcinogenesis in mammalian cells.

\section{Concluding remarks}

The emphasis of the present thesis was on the modulation of DNA repair by prooxidants and dietary antioxidants. Overall, it is clear that NER can be regulated by the intracellular redox status and that an antioxidant rich diet can compensate for the oxidative stress-induced effects on NER capacity, but larger studies with more subjects are needed. Although, only a small number of studies have assessed the influence of diet and dietary compounds on DNA repair processes so far, the results form our studies support the hypothesis that dietary compounds and whole foods may have an important influence on an individual's DNA repair capacity, especially in subjects that are exposed to high levels of oxidative stress. Since the protective effects of an individual's diet are suggested to be mainly the result of the combined effects of various bioactive compounds within whole foods rather than the effect of a single compound and considering the crucial role of DNA repair in human health and disease, additional investigations on the modulation of DNA repair by complex dietary mixtures is required. Extended research is also needed to further elucidate the molecular mechanisms underlying the effects of dietary compounds on DNA repair and whether genetic factors influence the direction and magnitude of the phenotypic response.

Next to DNA repair processes, DNA damage tolerance mechanisms, involving ubiquitination, guard against chemical carcinogenesis by preventing mutagenesis and thus contributing to genomic stability. As such, alterations in ubiquitination and the genes that control this process may influence the susceptibility of individuals to environmental mutagens and carcinogens. For instance, studies have reported that oxidative stress can modulate the ubiquitination process via reversible $S$ thiolation/dethiolation of ubiquitin-conjugating enzymes [30-32]. Consequently, modulation of the redox status by dietary factors could have major consequences on the proper functioning of enzymes involved in lysine 63-linked poly-ubiquitination of PCNA, which may lead to the inefficient bypass of persisting lesions. A major challenge would thus be to investigate if dietary antioxidants can protect the ubiquitination process that is involved in damage tolerance against the deleterious effects of oxidative stress. Therefore, additional studies are needed to further elucidate the mechanism and modulating factors of damage tolerance pathways in humans, and to appreciate their role in cancer development upon exposure to environmental agents.

When summarising the results as described in this thesis, it can be concluded that the newly developed in vitro repair assay is a reliable, sensitive and thoroughly 


\section{Chapter 7}

validated method for the phenotypic assessment of the NER capacity. It provides a powerful tool to further substantiate the role of DNA repair in the development of cancer and to provide answers to important research questions on DNA repair and human health. The results presented in this thesis may open doors for new applications of DNA repair measurements as a biomarker of susceptibility in molecular epidemiological studies. Analysing phenotypic biomarkers in parallel with genetic susceptibility markers, promises to yield valuable information on genotype-phenotype interactions, which may in turn be helpful in the identification of susceptible subpopulations and individuals that may benefit from specific dietary interventions. However, further and larger studies into the joint effect of genetic polymorphisms and dietary factors on the phenotypic DNA repair capacity require high throughput, less-labour intensive methods and development of these technologies should be prioritized in order to improve progression in this research area. 


\section{References}

1. Hansen W. K. and Kelley M. R. Review of mammalian DNA repair and translational implications. J Pharmacol Exp Ther 2000;295:1-9.

2. Friedberg E. C. DNA damage and repair. Nature 2003;421:436-440.

3. Collins A. R., Dusinska M., Horvathova E., Munro E., Savio M. and Stetina R. Interindividual differences in repair of DNA base oxidation, measured in vitro with the comet assay. Mutagenesis 2001;16:297-301.

4. Gaivao I., Piasek A., Brevik A., Shaposhnikov S. and Collins A. R. Comet assaybased methods for measuring DNA repair in vitro; estimates of inter- and intraindividual variation. Cell Biol Toxicol 2007.

5. Tyson J. and Mathers J. C. Dietary and genetic modulation of DNA repair in healthy human adults. Proc Nutr Soc 2007;66:42-51.

6. Cross C. E., Halliwell B., Borish E. T., Pryor W. A., Ames B. N., Saul R. L., McCord J. M. and Harman D. Oxygen radicals and human disease. Ann Intern Med 1987; 107:526-545.

7. Cerutti P. A. Prooxidant states and tumor promotion. Science 1985;227:375-381.

8. Hu J. J., Dubin N., Kurland D., Ma B. L. and Roush G. C. The effects of hydrogen peroxide on DNA repair activities. Mutat Res 1995;336:193-201.

9. Topinka J., Binkova B., Sram R. J. and Fojtikova I. DNA-repair capacity and lipid peroxidation in chronic alcoholics. Mutat Res 1991;263:133-136.

10. Fratelli M., Goodwin L. O., Orom U. A., Lombardi S., Tonelli R., Mengozzi M. and Ghezzi P. Gene expression profiling reveals a signaling role of glutathione in redox regulation. Proc Natl Acad Sci U S A 2005;102:13998-14003.

11. Feng Z., Hu W. and Tang M. S. Trans-4-hydroxy-2-nonenal inhibits nucleotide excision repair in human cells: a possible mechanism for lipid peroxidation-induced carcinogenesis. Proc Natl Acad Sci U S A 2004;101:8598-8602.

12. Feng Z., Hu W., Marnett L. J. and Tang M. S. Malondialdehyde, a major endogenous lipid peroxidation product, sensitizes human cells to UV- and BPDEinduced killing and mutagenesis through inhibition of nucleotide excision repair. Mutat Res 2006;601:125-136.

13. Hiramatsu K., Ogino T., Ozaki M. and Okada S. Monochloramine inhibits ultraviolet B-induced p53 activation and DNA repair response in human fibroblasts. Biochim Biophys Acta 2006;1763:188-196.

14. Dabholkar M. D., Berger M. S., Vionnet J. A., Egwuagu C., Silber J. R., Yu J. J. and Reed E. Malignant and nonmalignant brain tissues differ in their messenger RNA expression patterns for ERCC1 and ERCC2. Cancer Res 1995;55:1261-1266.

15. Vogel U., Dybdahl M., Frentz G. and Nexo B. A. DNA repair capacity: inconsistency between effect of over-expression of five NER genes and the correlation to mRNA levels in primary lymphocytes. Mutat Res 2000;461:197-210.

16. Wei Q., Xu X., Cheng L., Legerski R. J. and Ali-Osman F. Simultaneous amplification of four DNA repair genes and beta-actin in human lymphocytes by multiplex reverse transcriptase-PCR. Cancer Res 1995;55:5025-5029.

17. Zhou W., Liu G., Park S., Wang Z., Wain J. C., Lynch T. J., Su L. and Christiani D. C. Gene-smoking interaction associations for the ERCC1 polymorphisms in the risk of lung cancer. Cancer Epidemiol Biomarkers Prev 2005;14:491-496.

18. Zienolddiny S., Campa D., Lind H., Ryberg D., Skaug V., Stangeland L., Phillips D. $\mathrm{H}$., Canzian F. and Haugen A. Polymorphisms of DNA repair genes and risk of nonsmall cell lung cancer. Carcinogenesis 2006;27:560-567.

19. Wilms L. C., Hollman P. C., Boots A. W. and Kleinjans J. C. Protection by quercetin and quercetin-rich fruit juice against induction of oxidative DNA damage and formation of BPDE-DNA adducts in human lymphocytes. Mutat Res 2005;582:155162. 


\section{Chapter 7}

20. Wilms L. C., Boots A. W., de Boer V. C., Maas L. M., Pachen D. M., Gottschalk R. W., Ketelslegers H. B., Godschalk R. W., Haenen G. R., van Schooten F. J. and Kleinjans J. C. Impact of multiple genetic polymorphisms on effects of a 4-week blueberry juice intervention on ex vivo induced lymphocytic DNA damage in human volunteers. Carcinogenesis 2007;28:1800-1806.

21. Hunninghake G. W., Gadek J. E., Lawley T. J. and Crystal R. G. Mechanisms of neutrophil accumulation in the lungs of patients with idiopathic pulmonary fibrosis. $J$ Clin Invest 1981;68:259-269.

22. Noguera A., Batle S., Miralles C., Iglesias J., Busquets X., MacNee W. and Agusti A. G. Enhanced neutrophil response in chronic obstructive pulmonary disease. Thorax 2001;56:432-437.

23. Gungor N., Godschalk R. W., Pachen D. M., Van Schooten F. J. and Knaapen A. M. Activated neutrophils inhibit nucleotide excision repair in human pulmonary epithelial cells: role of myeloperoxidase. Faseb J 2007;21:2359-2367.

24. Broomfield S., Hryciw T. and Xiao W. DNA postreplication repair and mutagenesis in Saccharomyces cerevisiae. Mutat Res 2001;486:167-184.

25. Wang Z. DNA damage-induced mutagenesis : a novel target for cancer prevention. Mol Interv 2001;1:269-281.

26. Hoege C., Pfander B., Moldovan G. L., Pyrowolakis G. and Jentsch S. RAD6dependent DNA repair is linked to modification of PCNA by ubiquitin and SUMO. Nature 2002;419:135-141.

27. Hofmann R. M. and Pickart C. M. Noncanonical MMS2-encoded ubiquitinconjugating enzyme functions in assembly of novel polyubiquitin chains for DNA repair. Cell 1999;96:645-653.

28. Spence J., Sadis S., Haas A. L. and Finley D. A ubiquitin mutant with specific defects in DNA repair and multiubiquitination. Mol Cell Biol 1995;15:1265-1273.

29. Zhang Y., Wu X., Guo D., Rechkoblit O., Geacintov N. E. and Wang Z. Two-step error-prone bypass of the (+)- and (-)-trans-anti-BPDE-N2-dG adducts by human DNA polymerases eta and kappa. Mutat Res 2002;510:23-35.

30. Jahngen-Hodge J., Obin M. S., Gong X., Shang F., Nowell T. R., Jr., Gong J., Abasi $\mathrm{H}$., Blumberg J. and Taylor A. Regulation of ubiquitin-conjugating enzymes by glutathione following oxidative stress. J Biol Chem 1997;272:28218-28226.

31. Obin M., Shang F., Gong X., Handelman G., Blumberg J. and Taylor A. Redox regulation of ubiquitin-conjugating enzymes: mechanistic insights using the thiolspecific oxidant diamide. Faseb J 1998;12:561-569.

32. Berlett B. S. and Stadtman E. R. Protein oxidation in aging, disease, and oxidative stress. J Biol Chem 1997;272:20313-20316. 




\section{Samenvatting en Algemene Discussie}

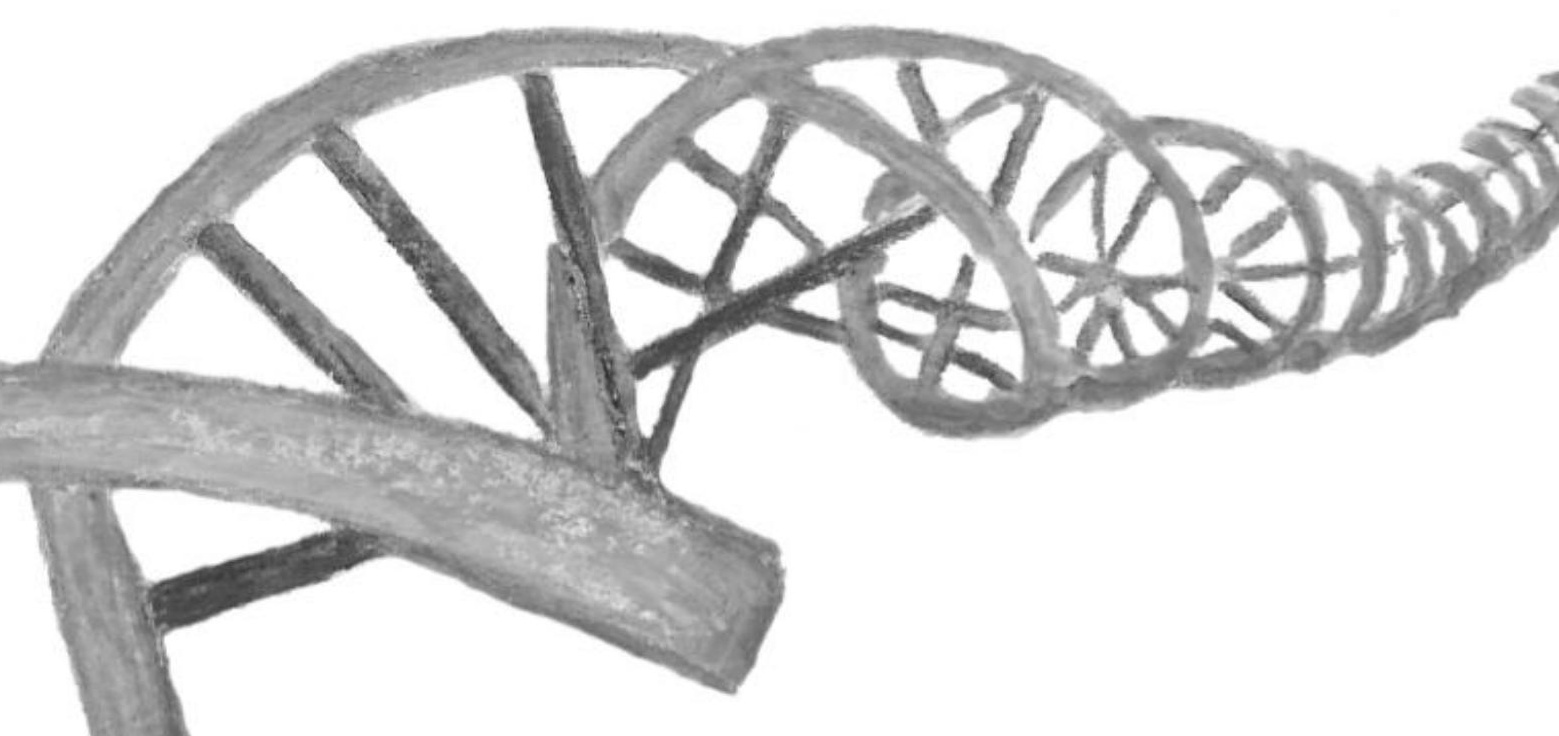


Alle levende organismen worden blootgesteld aan een waaier van potentieel schadelijke stoffen, die voortkomen uit het milieu, de voeding of zelfs uit endogene processen. Deze stoffen kunnen het cellulaire DNA beschadigen en wanneer zulke beschadigingen niet hersteld worden, kunnen deze laesies uiteindelijk leiden tot het ontstaan van mutaties. Mutaties kunnen op hun beurt resulteren in afwijkingen in de expressie van genen en het functioneren van de genproducten, welke kunnen leiden tot de initiatie van ziektes zoals kanker. Ondanks dat DNA schades iedere dag met relatief hoge frequenties optreden in ons lichaam, is het optreden van mutaties in vergelijking laag. Dit is te danken aan de brede variatie aan DNA herstel mechanismen die een organisme bezit om de integriteit van zijn genoom te waarborgen. Mede daardoor spelen DNA herstel processen een belangrijke rol in de preventie van kanker. Zo beschikt ook de mens over verschillende processen om het beschadigde DNA te herstellen; waaronder het nucleotide excisie herstel (NER) en base excisie herstel (BER) [1,2].

Aangezien DNA herstel één van de processen is om de initiatie van kanker als gevolg van DNA schade te voorkomen, kan het meten ervan gezien worden als een relevante biomarker bij het bepalen van individuele kanker risico's. Voor het zover is, moet er echter eerst informatie vergaard worden over de intra- en interindividuele variaties in DNA herstel capaciteiten binnen een gezonde humane populatie. Deze fenotypische variaties worden gedeeltelijk veroorzaakt door zogenaamde genetische polymorfismen in DNA herstel genen, die kunnen leiden tot significante verschillen in de synthese en activiteit van de herstel enzymen. Daarnaast, zijn er nog andere factoren zoals exogene en endogene stoffen die het DNA herstel kunnen beïnvloeden. Vooral de modulatie van DNA herstel door voeding en voedingscomponenten zou verder onderzocht moeten worden, omdat dit mogelijkheden kan bieden voor effectieve preventie van kanker. Verder, suggereren zowel in vitro als in vivo studies dat de DNA herstel capaciteit door de redox status van de cel beïnvloedt kan worden, door onder andere de expressie van essentiële herstel enzymen te verhogen of verlagen. Aangezien de cellulaire redox status kan veranderen naarmate er meer of minder pro-oxidanten en anti-oxidanten aanwezig zijn in de voeding, was het doel van de huidige thesis om te bestuderen of men door modulatie van de redox status door middel van voedingsinterventies, de NER capaciteit kan verbeteren. Om deze invloed van voedingsfactoren op de NER capaciteit te kunnen bepalen, zijn er echter eerst simpele en betrouwbare technieken nodig die gebruikt kunnen worden om NER capaciteiten van mensen te bepalen.

In het verleden werden reeds verschillende methoden ontwikkeld die inderdaad DNA herstel kunnen bepalen. Deze technieken waren voornamelijk gebaseerd op de behandeling van cellen met schadelijke stoffen, waarna de verwijdering van deze schade over de tijd geregistreerd werd [beschreven in Hoofdstuk 1]. De grootste beperking van zulke toepassingen is dat ze tijdrovend zijn, verse cellen vereisen of cellen die speciaal behandeld moeten worden om overleving na invriezen te verzekeren. Alternatieve methoden zijn o.a. de "in vitro repair assays", die 
afhankelijk zijn van de incubatie van een eiwit-extract uit cellen met een DNA substraat dat specifieke laesies bevat. Deze technieken zijn over het algemeen gevoeliger en meer geschikt voor het bepalen van DNA herstel in bevroren bloedmonsters, zoals ingevroren humane lymfocyten. Recentelijk, werd er door Collins et al. een "in vitro repair assays" ontwikkeld op basis van de zogenaamde "single-cell gel electrophoresis (comet) assay", om de fenotypische BER capaciteit te kunnen meten [3]. Deze alternatieve methode meet de capaciteit van humane lymfocyt extracten om de initiële stappen van BER; namelijk de schade herkenning en incisie, op DNA substraten met 8-oxoguanine laesies uit te voeren. Echter, tot op heden waren er voor zover ons bekend slechts enkele comet-gebaseerde methoden beschikbaar die NER kunnen meten. Nochtans, zijn verscheidene humane kankers direct gerelateerd met blootstelling aan chemicaliën zoals polycyclische aromatische koolwaterstoffen (PAK), die hun kankerverwekkende werking uitoefenen door de vorming van DNA addukten, welke voornamelijk verwijderd worden door NER. Daarom werd er een gemodificeerde comet assay ontwikkeld, zoals beschreven in Hoofdstuk 2 van deze thesis, om inter-individuele verschillen in nucleotide excisie herstel te kunnen bepalen. In deze nieuwe "repair assay" bestaat het DNA substraat uit nucleoïds opgenomen in een gel, die blootgesteld werden aan ( \pm )-antibenzo[a]pyrene-7,8-dihydrodiol-9,10-epoxide (BPDE), om BPDE-DNA addukten te induceren. Deze BPDE-DNA addukten zijn een bekend substraat voor het NER proces en bij incubatie van deze beschadigde nucleoïds met cel extracten, zullen de herstel enzymen in deze extracten de eerste stappen van NER kunnen uitvoeren; namelijk de DNA schade herkenning en incisie. Als gevolg hiervan zullen er enkelstrengs DNA breuken ontstaan, die vervolgens na electroforese gevisualiseerd kunnen worden in de vorm van een staart aan de nucleoïd. De lengte van deze staart en de hoeveelheid DNA dat zich erin bevindt is een maat voor de hoeveelheid breuken dat gevormd is en geeft een indicatie over de DNA herstel capaciteit van het cel extract (zie Figuur 1 van Hoofdstuk 2). Extracten van $X P A^{-/}$en $X P C^{-/-}$ fibroblasten, die deficiënt zijn voor de proteïnen vereist voor de initiële stappen van NER, werden gebruikt om deze assay te valideren. Humane lymfocyt extracten vertoonden $\sim 8$-voudige verschillen in hun DNA herstel capaciteit, wat bleek te correleren met de verwijdering van BPDE-DNA addukten in dezelfde lymfocyten over een periode van 48 uur zoals bepaald met ${ }^{32} \mathrm{P}$-postlabeling. Gelijkaardige verschillen werden waargenomen in humane lymfocyten door Gaivao et al., welke een alternatieve in vitro NER assay toepaste die gebruik maakt van nucleoïd-DNA dat UV-geïnduceerde laesies bevat [4]. Dit zijn relatief grote variaties in NER capaciteiten in vergelijking met de inter-individuele $\sim 4$-voudige verschillen die gerapporteerd werden voor BER [4]. Opmerkelijk is dat bepaalde gezonde individuen zelfs een relatief lage NER capaciteit bleken te hebben, zoals gemeten werd met de comet-gebaseerde "in vitro repair assays". Dit zou kunnen leiden tot een opstapeling van DNA schades na blootstelling aan genotoxische stoffen en vervolgens resulteren in een verhoogd risico op mutaties en kanker. Anderzijds, kan een lagere NER capaciteit ook het gevolg zijn van een geringe behoefte aan herstel 
door de afwezigheid van DNA-laesies, aangezien DNA schade de NER enzymen direct kan activeren via feedback controle mechanismen. Vandaar dat het belangrijk is om de DNA herstel capaciteit steeds in combinatie met de blootstelling te bepalen (bv. door het gebruik van blootstellings biomarkers), zodat er betrouwbare voorspellingen gedaan kunnen worden over de gevoeligheid van een individu om kanker te ontwikkelen. Desondanks kan men suggereren dat een verslechtering van het DNA herstel proces zal leiden tot een verhoogd risico op ziektes zoals kanker. Algemeen gezien, is deze nieuw ontwikkelde methode betrouwbaar, reproduceerbaar en kan gebruikt worden voor verse en bevroren lymfocyten, waardoor deze methode goed toepasbaar is in moleculair epidemiologische studies.

Onze in vitro NER assay werd vervolgens toegepast in een in vitro studie, als een eerste stap om de invloed van voedingsfactoren op het DNA herstel te onderzoeken. Een lage inname van bepaalde nutriënten kan een effect hebben op het DNA herstel [5], maar de moleculaire mechanismen waarlangs de voeding dit proces kan moduleren zijn nog steeds onduidelijk. Eén van de mogelijke mechanismen verloopt via de vorming van vrije radicalen, zoals reactieve zuurstof species (RZS). Anti-oxidanten uit de voeding kunnen RZS, die betrokken zijn bij de initiatie en de promotie van kankerontwikkeling [6,7], wegvangen; RZS zouden anders de herstel mechanismen kunnen remmen. In vitro en in vivo studies hebben inderdaad gerapporteerd dat een balans tussen oxidanten en anti-oxidanten van belang is voor het goed functioneren van het DNA herstel, inclusief NER [8,9]. Het doel van het in vitro onderzoek, zoals beschreven in Hoofdstuk 3, was er daarom op gericht om verder inzicht te verkrijgen in de relatie tussen oxidatieve stress en NER, zowel op het niveau van transcriptie als het daadwerkelijk functioneren van de betrokken proteïnen. Teneinde de intracellulaire redox status te moduleren, werd gebruik gemaakt van niet-cytotoxische doses van waterstofperoxide $\left(\mathrm{H}_{2} \mathrm{O}_{2}\right)$ en/ of van $D, L$-buthione-S,R-sulfoximine (BSO) om de natuurlijke cellulaire antioxidant glutathion (GSH) te depleteren. Om het effect van oxidatieve stress op de genexpressie te bestuderen, werden er specifieke genen geselecteerd die coderen voor NER proteïnen welke specifiek betrokken zijn bij de DNA schade herkenning en incisie (de stappen die ook gemeten worden in onze in vitro NER assay). De expressie van de meerderheid van de geselecteerde NER genen was verhoogd na blootstelling aan $\mathrm{H}_{2} \mathrm{O}_{2}$. Een mogelijke verklaring hiervoor is dat verscheidene genen die betrokken zijn bij de cellulaire verdediging, gecontroleerd worden door redoxgevoelige transcriptie factoren zoals AP-1. Desondanks, was de expressie van het DNA herstel gerelateerde gen ERCC1, waarvan gerapporteerd wordt dat het ook een AP-1 bindingssequentie in zijn promotor gebied bezit, significant verlaagt door $\mathrm{H}_{2} \mathrm{O}_{2}$. Echter, Fratelli et al. toonden aan dat de expressie van de AP-1 subunits, Fos en FosB, niet geïnduceerd werd door blootstelling aan $\mathrm{H}_{2} \mathrm{O}_{2}$ alleen, maar sterk geïnduceerd was in GSH gedepleteerde cellen [10]. Het herstellen van de ERCC1 expressie, zoals werd gezien in onze studie in de GSH gedepleteerde cellen die blootgesteld waren aan $\mathrm{H}_{2} \mathrm{O}_{2}$, zou dus gedeeltelijk verklaard kunnen worden door de activatie van deze transcriptie factor. Deze bevindingen suggereren dat GSH een 
signalisatie rol heeft in de redox-gereguleerde genexpressie van NER genen. Verdere studies zijn echter vereist om deze resultaten te verifiëren en de onderliggende mechanismen te begrijpen.

Aangezien de meerderheid van de gerelateerde NER genen een verhoogde expressie vertoonden na blootstelling aan $\mathrm{H}_{2} \mathrm{O}_{2}$, werd er ook een verhoging van de fenotypische NER capaciteit verwacht. De blootstelling aan $\mathrm{H}_{2} \mathrm{O}_{2}$ resulteerde echter in een acute inhibitie van de NER capaciteit, wat significant correleerde met de ERCC1 gen expressie $\left(\mathrm{R}^{2}=0.85, \mathrm{p}<0.01\right)$. De geobserveerde inhibitie van NER door $\mathrm{H}_{2} \mathrm{O}_{2}$ in onze studie, kwam overeen met bevindingen van $\mathrm{Hu}$ et al. [8]. Andere studies, die onze data verder onderbouwen, toonden aan dat lipide peroxidatie producten (bv. 4-hydroxynonenal, malondialdehyde) potente inhibitoren kunnen zijn van NER, hoogst waarschijnlijk als gevolg van directe oxidatieve aanval en inactivatie van NER proteïnen [11-13]. Bovendien, werden onze in vitro bevindingen van Hoofdstuk 3 bevestigd door een daaropvolgende in vivo studie, die beschreven wordt in Hoofdstuk 4. In pasgeboren biggen werd oxidatieve stress geïnduceerd door ze bloot te stellen aan ijzer. Oxidatieve stress werd vervolgens geregistreerd als verhoogde niveaus van 8-oxo-7,8-dihydro-2'-deoxyguanosine (8-oxodG) in het DNA van de colon en in de urine. De stijging in oxidatieve stress resulteerde in een verlaging van de NER capaciteit in de colon weefsels met maar liefst $70 \%$. Aangezien anti-oxidanten de redox status kunnen moduleren door het wegvangen van RZS en lipide peroxidatie producten, werd er gesteld dat het remmende effect van de oxidatieve stress op het DNA herstel, gecompenseerd kon worden door suppletie met anti-oxidant rijke voeding. De suppletie van de moeder zeugen met een anti-oxidant verrijkte voeding bleek in deze in vivo studie inderdaad de oxidatieve stress-geïnduceerde daling in NER capaciteit, in de colon van hun nageslacht, gedeeltelijk te compenseren. De fenotypische NER capaciteit was significant minder gereduceerd door de oxidatieve stress in de gesupplementeerde groep dan in de niet-gesupplementeerde dieren $(30 \%$ gereduceerd in plaats van $70 \%$ ). Voedings-interventies kunnen het nucleotide excisie herstel proces, dat zorgt voor het behoud van de genoomstabiliteit, dus beschermen tegen de oxidatieve stress-geïnduceerde schadelijke effecten.

Gebaseerd op onze voorgaande bevindingen, werd verondersteld dat een verhoogde inname van anti-oxidanten via de voeding de NER capaciteit van een individu zou kunnen verhogen. Aangezien zogenaamde "single nucleotide polymorfismen" (SNPs) in DNA herstel genen ook een belangrijke invloed kunnen hebben op de gemeten DNA herstel capaciteit, kan het effect van de interventie met anti-oxidanten afhankelijk zijn van de genetische achtergrond van een individu. Bijgevolg, beschrijft Hoofdstuk 5 van deze thesis een humane interventie studie waarin de effecten van verhoogde anti-oxidant inname, van genetische polymorfismen in NER genen, en van mogelijke interacties tussen beide factoren op de fenotypische NER capaciteit onderzocht worden. Van 168 gezonde vrijwilligers, die $1 \mathrm{~L}$ blauwe bessen/appel sap per dag consumeerden gedurende 4 weken, werd voor en na de interventie bloed verzameld. Al de proefpersonen werden eerst 
gegenotypeerd voor 11 SNPs in NER-gerelateerde genen, door middel van een Multiplex PCR amplificatie gevolgd door een "single base extension" (SBE) gebaseerde methode die speciaal voor deze studie opgezet werd. Op basis van de genotype frequenties, werd een subpopulatie van 36 gezonde vrijwilliger geselecteerd voor de fenotypische bepaling van de NER capaciteit. Aangezien we eerder een significante correlatie tussen de NER capaciteit en de ERCC1 genexpressie waargenomen hadden [Hoofdstuk 3] en omdat andere studies ook positieve correlaties van de DNA herstel capaciteit met ERCC1 expressie rapporteerden [14-16], vond deze selectie plaats op basis van de ERCC1 genotypes. Echter, in de interventie studie zoals beschreven in Hoofdstuk 5, werden geen significante associaties tussen de ERCC1 polymorfismen en de NER capaciteit gevonden. Ook andere studies rapporteerden dat een relatie tussen ERCC1 polymorphismen en de NER capaciteit niet gevonden kon worden $[17,18]$ en de functionele relevantie van SNPs in het ERCC1 gen blijven dus onduidelijk. Het veel voorkomende genetische polymorfisme XPA-A23G vertoonde wel significante correlaties met de NER capaciteit in onze humane interventie studie; dragers van het GG genotype vertoonden een $~ 3-k e e r$ hogere NER capaciteit in vergelijking met de homozygote wild-type en heterozygote proefpersonen. Aangezien deze associatie niet beïnvloed werd door de voedingsinterventie, blijkt het XPA-A23G polymorfisme een goede voorspeller te zijn van de NER capaciteit, zoals bepaald met onze in vitro NER assay. Verder, werd het effect van de vier weken durende interventie met het anti-oxidant rijke blauwe bessen/appel sap op de NER capaciteit geëvalueerd en de eventuele genotype-voedingsinteracties bestudeerd. Ondanks dat de interventie eerder efficiënt bevonden was in het verhogen van de anti-oxidant capaciteit en het reduceren van ex vivo geïnduceerde oxidatieve schade $[19,20]$, zagen wij in onze studie over het algemeen geen effect van de voedingsinterventie op de NER capaciteit [Hoofdstuk 5]. Echter, dragers van variante/risico allelen voor XPC-K939Q en RAD23B-A249V bleken wel baat te hebben bij de interventie. Zij vertoonden verhoogde NER capaciteiten na de interventie, wat niet geobserveerd werd in hun homozygote wild-type tegenhangers. Bijgevolg, ondersteunen onze resultaten de hypothese dat genetische polymorfismen de fenotypische DNA herstel capaciteit kunnen beïnvloeden en dat dit verder gemoduleerd kan worden door de voeding. Het effect van de voeding blijk hierin echter een kleinere rol te spelen dan de effecten van genetische variatie.

Een reductie in de DNA herstel capaciteit tijdens ziekten die gepaard gaan met oxidatieve stress, kan bijdragen tot het ontstaan van mutaties en kanker. Bijvoorbeeld chronische inflammatoire long ziekten, zoals sarcoidosis, fibrosis en chronische obstructieve pulmonaire ziekte (COPD), worden gekarakteriseerd door de influx van polymorfe neutrofielen (PMNs) die hoge concentraties RZS produceren [21,22], wat vervolgens de balans tussen oxidanten en anti-oxidanten verstoort. Van deze PMNs werd aangetoond dat zij potente inhibitoren zijn van NER in humane long epitheel cellen [23]. Deze bevindingen vormen een mogelijke additionele biologische verklaring voor de associatie tussen inflammatie en long 
kanker. In zulke situaties van chronische oxidatieve stress, kan minder efficiënt DNA herstel leiden tot het achter blijven en opstapellen van DNA laesies, die mogelijk de voortgang van de replicatie-vork kunnen blokkeren. Om het instorten van de DNA replicatie-vork en de daarop volgende vorming van dubbel strengs DNA breuken te vermeiden, beschikken cellen over DNA schade tolerantie (DDT) mechanismen die instaat zijn de laesie te omzeilen en de replicatie voor te zetten [24,25]. In eukaryoten zijn er twee DDT mechanismen bekend; namelijk het DNA schade omzeilingmechanisme en de translaesie synthese (TLS). Het laatst genoemde mechanisme wordt met name uitgevoerd door de onbetrouwbare translaesie polymerasen (bv. Pol $\eta$, Pol $\kappa$, Pol $\zeta$ ) die de gebruikelijke replicatie DNA polymerasen (Pol $\delta$ or Pol $\varepsilon$ ) tijdelijk vervangen en op die manier een nucleotide inbouwen tegenover de laesie. Of de juiste of onjuiste base wordt ingebouwd is afhankelijk van de betrokken TLS polymerase en het type van DNA schade. Aangezien TLS polymerasen direct de beschadigde streng kopiëren, gaat dat vaak gepaard met fouten en kunnen er mutaties ontstaan die op hun beurt weer bijdragen tot het ontstaan van kanker. In tegenstelling tot TLS, gebruikt het DNA schade omzeilingmechanisme de informatie van de onbeschadigde zuster streng en passeert op die manier de laesie op een foutloze manier. Ondanks het feit dat de opeenvolgende stappen in dit mechanisme nog onduidelijk zijn, wordt er gesuggereerd dat het gepaard gaat met zogenaamde "template switching" en dat het kenmerken deelt met het homologe recombinatie systeem. Verder hebben studies in gist aangetoond dat het modificeren van "proliferating cell nuclear antigen" (PCNA) met lysine 63-gelinkte poly-ubiquitine ketens, het passeren van DNA laesies bevorderd en dat dit proces mede bepaald of de schade wordt omzeild door het foutloze omzeilingmechanisme of door het fouten inducerende TLS [26-28]. In Hoofdstuk 6 hebben we aangetoond dat PCNA, na blootstelling aan benzo[a]pyrene-7,8-dihydrodiol-9,10-epoxide (BPDE), ook poly-ubiquitinatie ondergaat in humane lung epitheel cellen (A549 cellen). Verstoring van de vorming van deze lysine 63-gelinkte poly-ubiquitine ketens bleek de mutageniteit van BPDE te verhogen, wat hoogst waarschijnlijk te wijten was aan de verhoogde rekrutering van de TLS polymerase Pol $\eta$. Eerdere studies suggereerden dat Pol $\eta$ de belangrijkste polymerase is die verantwoordelijk is voor de mutageniteit van BPDEDNA addukten, doordat het voornamelijk adenosine inbouwt tegenover BPDE- $N^{2}$ dG laesies en zo $G \rightarrow T$ transversies veroorzaakt [29]. Ook in onze studie, werd Pol $\eta$ na blootstelling aan BPDE in verhoogde mate gerekruteerd en geco-lokaliseerd met PCNA, wat voornamelijk (74\%) resulteerde in $\mathrm{G} \rightarrow \mathrm{T}$ mutaties. Verder kan gesuggereerd worden dat lysine 63-gelinkte poly-ubiquitinatie van PCNA een belangrijk proces is in de bescherming van humane cellen tegen BPDEgeïnduceerde mutageniteit, door het DNA schade tolerantie systeem in de richting van het foutloze omzeilingmechanisme te sturen. Daarom kan worden verondersteld dat de vorming van deze specifieke poly-ubiquitine ketens een algemene vereiste is voor de fysiologische bescherming tegen het ontstaan van mutaties en kanker na 
blootstelling aan stoffen die DNA leasies veroorzaken, die in staat zijn de replicatievork te stoppen.

\section{Conclusie}

De huidige thesis bestudeerd de effecten van oxidanten en anti-oxidanten op de activiteit van het nucleotide excisie DNA herstel systeem (NER). Over het algemeen kan gesteld worden dat NER gereguleerd kan worden door de intracellulaire redox status en dat een anti-oxidant rijke voeding de effecten van oxidatieve stress op NER kan compenseren. Ondanks dat er tot op heden slechts een klein aantal studies zijn verricht die de invloed van voeding en voedingscomponenten op het DNA herstel hebben bestudeerd, ondersteunen de resultaten van deze en onze studies de hypothese dat de samenstelling van de voeding een belangrijke invloed kan hebben op de DNA herstel capaciteit van een organisme, en dan met name bij organismen/organen die blootgesteld worden aan verhoogde niveaus van oxidatieve stress. Aangezien er gesuggereerd wordt dat de beschermende effecten van onze dagelijkse voeding eerder te wijten zijn aan de combinatie van verscheidene stoffen dan aan slechts enkele voedingscomponenten, en gezien de cruciale rol van het DNA herstel bij ziektes en de algemene gezondheid van de mens, zijn extra studies naar de modulatie van het DNA herstel door voedingsmengsels dringend nodig. Ook is er verder onderzoek vereist om de moleculaire mechanismen achter de effecten van de voeding op het DNA herstel verder te onthullen en te bestuderen of genetische factoren de manier en mate van de fenotypische response beïnvloeden.

Naast DNA herstel processen, dragen de DNA schade tolerantie mechanismen bij aan de stabiliteit van het genoom en de bescherming tegen chemische carcinogenese. Veranderingen in het ubiquitinatie proces of in de genen die dit proces controleren, zouden dus de gevoeligheid van individuen voor mutagenen en carcinogenen vanuit het milieu kunnen beïnvloeden. Zo hebben verschillende studies gerapporteerd dat het ubiquitinatie proces kan worden geremd via de omkeerbare oxidatie van functionele thiol-groepen in ubiquitine-conjugatie enzymen [30-32]. De modulatie van de redox status door voedingsfactoren zou dus ook belangrijke gevolgen kunnen hebben voor het goed functioneren van de enzymen die betrokken zijn bij de lysine 63-gelinkte poly-ubiquitinatie van PCNA, wat nodig is om achtergebleven DNA laesies te omzeilen. Het zou een grote uitdaging zijn om na te gaan of anti-oxidanten uit de voeding ook het ubiquitinatie proces dat betrokken is bij de tolerantie van DNA schade kan beschermen tegen de schadelijke effecten van oxidatieve stress.

Als we uiteindelijk alle resultaten zoals beschreven in deze thesis zouden samenvatten, kan er geconcludeerd worden dat de nieuwe "in vitro repair assay" een betrouwbare, gevoelige en deels gevalideerde techniek is, die gebruikt kan worden voor het fenotyperen van de NER capaciteit. Het is een zeer nuttige 
toepassing, waarmee we de rol van het DNA herstel in de ontwikkeling van kanker verder kunnen bestuderen en waardoor antwoorden geleverd zullen worden op belangrijke onderzoeksvragen met betrekking tot veranderingen in DNA herstel en de algemene gezondheid van de mens. De resultaten zoals beschreven in deze thesis, leveren mogelijkheden voor nieuwe toepassingen van het meten van DNA herstel, als een biomarker van gevoeligheid in moleculaire epidemiologische studies. Het analyseren van fenotypische biomarkers in parallel met genetische gevoeligheidsmarkers beloofd waardevolle informatie op te leveren over relevante genotype-fenotype interacties. Deze informatie kan op zijn beurt nuttig zijn bij het identificeren van gevoelige subpopulaties die baat kunnen hebben bij specifieke voedingsinterventies. Echter, verdere en grotere studies naar het gecombineerde effect van genetische polymorfismen en voedingsfactoren op de fenotypische DNA herstel capaciteit, vereisen productievere en minder arbeidsintensieve technieken. De ontwikkeling hiervan zou dan ook de eerste prioriteit moeten krijgen om de vooruitgang van dit onderzoeksveld te garanderen. 


\section{References}

1. Hansen W. K. and Kelley M. R. Review of mammalian DNA repair and translational implications. J Pharmacol Exp Ther 2000;295:1-9.

2. Friedberg E. C. DNA damage and repair. Nature 2003;421:436-440.

3. Collins A. R., Dusinska M., Horvathova E., Munro E., Savio M. and Stetina R. Interindividual differences in repair of DNA base oxidation, measured in vitro with the comet assay. Mutagenesis 2001;16:297-301.

4. Gaivao I., Piasek A., Brevik A., Shaposhnikov S. and Collins A. R. Comet assaybased methods for measuring DNA repair in vitro; estimates of inter- and intraindividual variation. Cell Biol Toxicol 2007.

5. Tyson J. and Mathers J. C. Dietary and genetic modulation of DNA repair in healthy human adults. Proc Nutr Soc 2007;66:42-51.

6. Cross C. E., Halliwell B., Borish E. T., Pryor W. A., Ames B. N., Saul R. L., McCord J. M. and Harman D. Oxygen radicals and human disease. Ann Intern Med 1987; 107:526-545.

7. Cerutti P. A. Prooxidant states and tumor promotion. Science 1985;227:375-381.

8. Hu J. J., Dubin N., Kurland D., Ma B. L. and Roush G. C. The effects of hydrogen peroxide on DNA repair activities. Mutat Res 1995;336:193-201.

9. Topinka J., Binkova B., Sram R. J. and Fojtikova I. DNA-repair capacity and lipid peroxidation in chronic alcoholics. Mutat Res 1991;263:133-136.

10. Fratelli M., Goodwin L. O., Orom U. A., Lombardi S., Tonelli R., Mengozzi M. and Ghezzi P. Gene expression profiling reveals a signaling role of glutathione in redox regulation. Proc Natl Acad Sci U S A 2005;102:13998-14003.

11. Feng Z., Hu W. and Tang M. S. Trans-4-hydroxy-2-nonenal inhibits nucleotide excision repair in human cells: a possible mechanism for lipid peroxidation-induced carcinogenesis. Proc Natl Acad Sci U S A 2004;101:8598-8602.

12. Feng Z., Hu W., Marnett L. J. and Tang M. S. Malondialdehyde, a major endogenous lipid peroxidation product, sensitizes human cells to UV- and BPDEinduced killing and mutagenesis through inhibition of nucleotide excision repair. Mutat Res 2006;601:125-136.

13. Hiramatsu K., Ogino T., Ozaki M. and Okada S. Monochloramine inhibits ultraviolet B-induced p53 activation and DNA repair response in human fibroblasts. Biochim Biophys Acta 2006;1763:188-196.

14. Dabholkar M. D., Berger M. S., Vionnet J. A., Egwuagu C., Silber J. R., Yu J. J. and Reed E. Malignant and nonmalignant brain tissues differ in their messenger RNA expression patterns for ERCC1 and ERCC2. Cancer Res 1995;55:1261-1266.

15. Vogel U., Dybdahl M., Frentz G. and Nexo B. A. DNA repair capacity: inconsistency between effect of over-expression of five NER genes and the correlation to mRNA levels in primary lymphocytes. Mutat Res 2000;461:197-210.

16. Wei Q., Xu X., Cheng L., Legerski R. J. and Ali-Osman F. Simultaneous amplification of four DNA repair genes and beta-actin in human lymphocytes by multiplex reverse transcriptase-PCR. Cancer Res 1995;55:5025-5029.

17. Zhou W., Liu G., Park S., Wang Z., Wain J. C., Lynch T. J., Su L. and Christiani D. C. Gene-smoking interaction associations for the ERCC1 polymorphisms in the risk of lung cancer. Cancer Epidemiol Biomarkers Prev 2005;14:491-496.

18. Zienolddiny S., Campa D., Lind H., Ryberg D., Skaug V., Stangeland L., Phillips D. $\mathrm{H}$., Canzian F. and Haugen A. Polymorphisms of DNA repair genes and risk of nonsmall cell lung cancer. Carcinogenesis 2006;27:560-567.

19. Wilms L. C., Hollman P. C., Boots A. W. and Kleinjans J. C. Protection by quercetin and quercetin-rich fruit juice against induction of oxidative DNA damage and formation of BPDE-DNA adducts in human lymphocytes. Mutat Res 2005;582:155162. 
20. Wilms L. C., Boots A. W., de Boer V. C., Maas L. M., Pachen D. M., Gottschalk R. W., Ketelslegers H. B., Godschalk R. W., Haenen G. R., van Schooten F. J. and Kleinjans J. C. Impact of multiple genetic polymorphisms on effects of a 4-week blueberry juice intervention on ex vivo induced lymphocytic DNA damage in human volunteers. Carcinogenesis 2007;28:1800-1806.

21. Hunninghake G. W., Gadek J. E., Lawley T. J. and Crystal R. G. Mechanisms of neutrophil accumulation in the lungs of patients with idiopathic pulmonary fibrosis. $J$ Clin Invest 1981;68:259-269.

22. Noguera A., Batle S., Miralles C., Iglesias J., Busquets X., MacNee W. and Agusti A. G. Enhanced neutrophil response in chronic obstructive pulmonary disease. Thorax 2001;56:432-437.

23. Gungor N., Godschalk R. W., Pachen D. M., Van Schooten F. J. and Knaapen A. M. Activated neutrophils inhibit nucleotide excision repair in human pulmonary epithelial cells: role of myeloperoxidase. Faseb J 2007;21:2359-2367.

24. Broomfield S., Hryciw T. and Xiao W. DNA postreplication repair and mutagenesis in Saccharomyces cerevisiae. Mutat Res 2001;486:167-184.

25. Wang Z. DNA damage-induced mutagenesis : a novel target for cancer prevention. Mol Interv 2001;1:269-281.

26. Hoege C., Pfander B., Moldovan G. L., Pyrowolakis G. and Jentsch S. RAD6dependent DNA repair is linked to modification of PCNA by ubiquitin and SUMO. Nature 2002;419:135-141.

27. Hofmann R. M. and Pickart C. M. Noncanonical MMS2-encoded ubiquitinconjugating enzyme functions in assembly of novel polyubiquitin chains for DNA repair. Cell 1999;96:645-653.

28. Spence J., Sadis S., Haas A. L. and Finley D. A ubiquitin mutant with specific defects in DNA repair and multiubiquitination. Mol Cell Biol 1995;15:1265-1273.

29. Zhang Y., Wu X., Guo D., Rechkoblit O., Geacintov N. E. and Wang Z. Two-step error-prone bypass of the (+)- and (-)-trans-anti-BPDE-N2-dG adducts by human DNA polymerases eta and kappa. Mutat Res 2002;510:23-35.

30. Jahngen-Hodge J., Obin M. S., Gong X., Shang F., Nowell T. R., Jr., Gong J., Abasi H., Blumberg J. and Taylor A. Regulation of ubiquitin-conjugating enzymes by glutathione following oxidative stress. J Biol Chem 1997;272:28218-28226.

31. Obin M., Shang F., Gong X., Handelman G., Blumberg J. and Taylor A. Redox regulation of ubiquitin-conjugating enzymes: mechanistic insights using the thiolspecific oxidant diamide. Faseb J 1998;12:561-569.

32. Berlett B. S. and Stadtman E. R. Protein oxidation in aging, disease, and oxidative stress. J Biol Chem 1997;272:20313-20316. 



\section{Appendix}

\section{Woord van Dank}

köszönöm !กтก děkuji mahalo 고맙습니다

\section{thank you}

merci 谢谢 danke

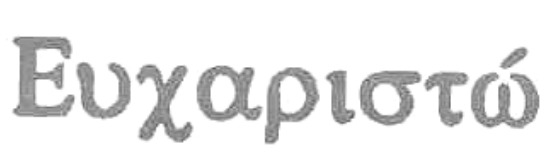

どうもありがとうｇracias 

Na een kwart eeuw door het leven te zijn gegaan, kom ik nu bij de volgende mijlpaal aan. Promoveren, na 4 jaren van uitdagend en leerzaam onderzoek, een bulk aan comets te scoren en nooit op te geven. Met de steun van velen heb ik dit onderzoek tot een goed einde gebracht en als afsluiting daarvan dit proefschrift geschreven. Bij dezen wil ik dan ook alle mensen bedanken die me de voorbije vier jaar iets hebben bijgebracht, steunden, maar ook deze periode tot een leuke ervaring maakten.

Allereerst wil ik mijn promotor Frederik-Jan van Schooten en co-promotor Roger Godschalk bedanken. Om te beginnen bedankt dat jullie me de gelegenheid gegeven hebben om aan dit promotieonderzoek te werken. Frederik-Jan, dank je wel dat je ondanks je drukke agenda, me tijdens deze periode met goede raad en begeleiding hebt bijgestaan. Ik ben erg dankbaar voor de kansen en ruimte die je me gaf om mijn netwerken en ervaringen te verruimen en me verder te kunnen ontwikkelen.

Roger, bedankt voor je begeleiding, interesse en enthousiasme. Je hebt me veel kennis en vaardigheden bijgebracht waardoor ik zelfstandiger ben geworden in het wetenschappelijk onderzoek. Ook wanneer het onderzoek wel eens tegen zat, wist je me steeds te motiveren om verder te blijven gaan. Bedankt hiervoor en voor de plezierige samenwerking.

Ad, ook aan jou heb ik veel te danken. Als begeleider tijdens mijn stage heb ik veel van jou geleerd. Tijdens mijn promotieonderzoek kwam je vaak met nuttige tips, die me steeds een stapje verder brachten.

Many thanks I express to everyone that helped and guided me during my stay in Oslo. Turid and Asgeir thank you for helping me in the lab during the first weeks of my visit, and Guro, Tina and Isabel thanks for making my stay in Oslo and at the lab more comfortable and pleasant. Takk deg meget mye! Muito obrigado!

Most of all, I would like to thank Andrew Collins for his guidance, support and useful advice during my visit at his lab, but also during my further PhD period. I could always mail you with questions, for which I am very thankful.

Verder wil ik de mensen van de afdeling Radio Oncology (MaastRO Lab) bedanken voor de goede samenwerking en hun bijdrage aan de DNA schade tolerantie studie. Met name Roland en Chantal, thanks for the nice cooperation!

Many thanks to all Polish co-authors of the DNA repair study in newborn piglets for the nice cooperation and critical reviews of the manuscript. Dziękuję bardzo!

Furthermore, I would like to thank Satu Hämäläinen for helping me to set up the SNaPShot-PCR technique to determine polymorphisms in nucleotide excision repair genes. Kiittää te!

I would also like to thank Leire, Amaia, Daneida, Bertrand, Daphnee, Raluca and other PhD students for the nice times and interesting talks we had at GRAT or at several international congresses. Muchas gracias! Merci beaucoup! Thanks! 
Naast al deze internationale contacten wil ik natuurlijk ook mijn 'Mestreechse' GRAT collega's bedanken. Om te beginnen de analisten van GRAT, waarop ik altijd heb kunnen rekenen. Jullie hebben me allen wel een keer ergens bij geholpen, al waren het enkel tips, ik ben jullie hiervoor zeer dankbaar. Karen Brauers, jou wil nog even specifiek bedanken voor de samenwerking en je hulp bij het opzetten van de 'comet-repair assay'.

Pascal, je bent dan inmiddels wel geen GRATer meer, maar ik blijf je toch zien als een collega. Reeds tijdens mijn stage stond je me ter hulp, met name bij het leren van het ${ }^{32} \mathrm{P}$-postlabelen, maar ook na je GRAT-tijd bleef je me steeds aanmoedigen in mijn onderzoek. Bedankt hiervoor en leuk dat je mijn paranimf wil zijn. En als ik ooit nog een gekke Kerstman of leuke ballonnenclown nodig heb, weet ik je wel te vinden $:$.

Vervolgens wil ik al mijn kamergenootjes bedanken voor de gezelligheid, steun en nuttige tips. Te beginnen met Simone en Yvonne Staal, die uiteindelijk plaatsmaakten voor 2 andere Belgische kamergenootjes Karen en Nejla. Het zou grappig geweest zijn als er nog een $4{ }^{\text {de }}$ Belg was bijgekomen, maar ik vond het toch fijn om Nicole in ons midden te hebben (-). Bovendien wil ik haar en Yvonne van Helden nogmaals bedanken voor de geslaagde samenwerking bij het organiseren van de NVT AIO/OIO dagen.

Daarnaast wil ik alle andere (ex)collega's en AlO's bedanken voor de steun, het advies over het proefschrift en promoveren, en de gezelligheid tijdens de gezamenlijke uitstapjes, lunchpauzes, etc.

Joyce, Erik, Joep, Sonja en Sarah, tijdens jullie stages hebben jullie relevante bijdrages geleverd aan mijn promotieonderzoek en het was erg plezierig om met jullie samen te werken en om te gaan. Bedankt hiervoor! Vielen Dank!

En uiteraard wil ik mijn team genoten Karen Mathijs en Joost Linschooten van het 'Generic Riskful Animation Team' bedanken voor de inspirerende brainstorms, de gezellige avondjes uit, de foute Kerstfeestjes en de leuke avonturen in Durbuy.

Vervolgens ook een woord van dank aan al mijn vrienden, kennissen en familieleden die me de afgelopen jaren gemotiveerd en met me meegeleefd hebben. Vooral mijn tUL-studiegenoten wil ik bedanken voor de steun tijdens onze studies, maar ook tijdens onze doctoraatsperiodes. Ik wens jullie nog veel succes met het afronden van jullie studies en promotieonderzoek

Ook wil ik mijn vrienden bedanken voor hun begrip en interesse. Vooral Veerle, voor haar steun en luisterend oor tijdens onze studies en kotleven. Ondanks dat je zelf niet de kans hebt gehad om te doctoreren, mag je straks toch meeproeven van het promotiegebeuren. Nog veel succes in Gent!

Familie en schoonfamilie, bedankt voor jullie interesse en steun. Henny en Gerard, ondanks dat jullie niet altijd konden volgen wat ik nu precies aan het onderzoeken was, wil ik jullie toch bedanken voor jullie interesse en medeleven. Opa, mijn peter, het was leuk om steeds te horen dat je mijn publicatielijst op internet bijhield en de artikels doornam, dat gaf me een zekere voldoening van mijn werk. In het bijzonder 
wil ik mijn meter, mijn bomma, bedanken voor het maken van de kaft van dit boekje. Ik kan je met vol enthousiasme zeggen dat ik het een schitterend eindresultaat vind.

Mijn grootste dank gaat natuurlijk uit naar mijn vriend, ouders en mijn broers. Allereerst wil ik mijn broerkes bedanken voor hun voortdurende interesse en behulpzaamheid. Pé \& Katrien, bedankt voor de gezellige spelavonden - de boog kan niet altijd gespannen staan $:$. . Kunchi, succes met het Solar Team, hopelijk zien we elkaar aan de Finish in Australië te Adelaide.

Mama \& papa bedankt voor jullie onvoorwaardelijke steun, toewijding en ouderliefde, jullie medeleven en geduld in goede en kwade tijden. Van kinds af aan hebben jullie me veel bijgebracht en geleerd nooit op te geven. De wijsheden uit de Disney film 'Merlijn de Tovenaar' zouden zo door jullie geschreven kunnen zijn;

"Hoger op naar de top, weg met de middelmatigheid. Zit niet stil, gebruik je wil, want niemand komt er zonder strijd! Kies zelf maar uit, hoe ver je gaat. Wie nooit begint komt steeds te laat! En da's waardoor de wereld draait."

Bedankt dat jullie er altijd voor me zijn!

En last but not least, wil ik mijn vriend Tom bedanken voor zijn liefde, begrip en steun. Bedankt voor de heerlijke maaltijden die steeds klaarstonden als ik thuis kwam, en voor je geduld en de ontstressende knuffels als ik gefrustreerd terug kwam van het werk. Veel tijd en energie is er in het afronden van dit boekje gekropen, maar zonder jou was dit nooit gelukt. Samen vormen we een goed team!
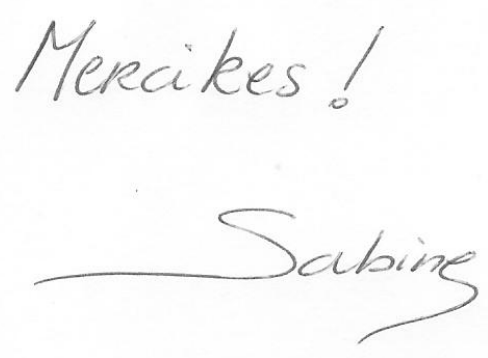



\section{Curriculum Vitae}

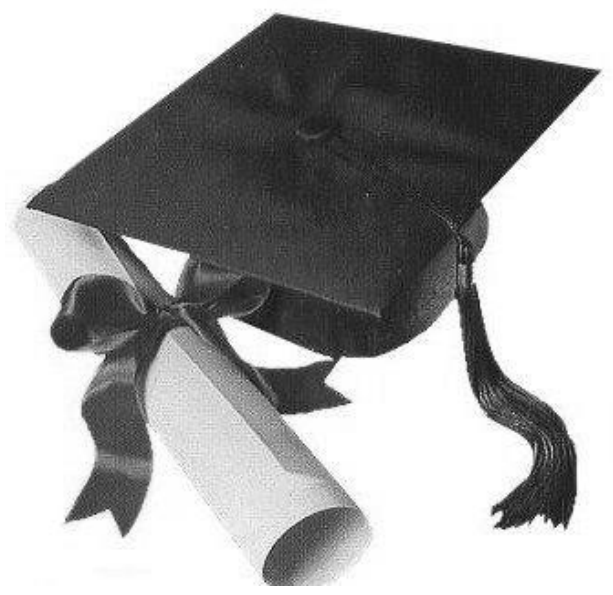


Sabine Agnes Stefanie Langie werd op 5 juni 1983 geboren in Hasselt, België. Na het behalen van haar secundair diploma in Techniek Wetenschappen aan het SintMaria Instituut te Neerpelt, is ze in 2000 aan het Limburgs Universitair Centrum (tegenwoordig Universiteit Hasselt) te Diepenbeek begonnen aan de studie 'Biomedische Wetenschappen'. Na de kandidatuurjaren, zette zij haar studie verder aan de transnationale Universiteit Limburg (tUL; samenwerking tussen Diepenbeek en Maastricht), waar zij in 2004 haar diploma 'Licentiaat in de Biomedische Wetenschappen / Doctorandus in de Gezondheidswetenschappen' behaalde. Tijdens deze studie deed ze stageonderzoek naar DNA schade tolerantie systemen en de mutageniteit van de kankerverwekkende stof benzo[a]pyreen, bij de capaciteitsgroep GezondheidsRrisico Analyse en Toxicologie (GRAT) aan de Universiteit Maastricht. Met dit onderzoek won ze de prijs voor beste afstudeerscriptie van 2004 binnen de Moleculaire Levenswetenschappen.

Aansluitend vanaf augustus 2004 tot en met juli 2008, was zij werkzaam als promovenda bij de capaciteitsgroep GRAT aan de Universiteit Maastricht. Haar promotie onderzoek, dat beschreven is in dit proefschrift, gebeurde onder begeleiding van Prof. Dr. F.J. van Schooten en Dr. R.W.L. Godschalk. In 2006 bracht zij, met dank aan een 'NuGO exchange grant', een werkbezoek van 3 maanden aan de afdeling 'Nutrition' van de Universiteit Oslo, waar ze in het laboratorium van Prof. Dr. Andrew R. Collins de 'in vitro base excision repair assay' leerde. Naast het uitvoeren van onderzoek, heeft ze ook verscheidene cursussen gevolgd en certificaten behaald; waaronder 'Stralingshygiëne deskundigheidsniveau $5^{\mathrm{B}}$, 'Proefdierkunde op grond van art. 9 van de Wet van Dierproeven' en verschillende modules van de 'Postdoctorale Opleiding Toxicologie' ten behoeve van registratie als toxicoloog. $\mathrm{Na}$ het behalen van haar doctors titel wil Sabine postdoctoraal onderzoek verrichten in het buitenland, waarvoor ze recentelijk een aantal projectaanvragen heeft ingediend. 
Sabine Agnes Stefanie Langie was born on June $5^{\text {th }} 1983$ in Hasselt, Belgium. After finishing secondary school in the discipline 'Technical Sciences' at the Sint-Maria Institute in Neerpelt, she started in 2000 her study in 'Biomedical Sciences' at the Limburg University Centre (currently University Hasselt) in Diepenbeek. After her first two years, she continued her study at the transnational University Limburg (tUL; collaboration between Diepenbeek and Maastricht), where she obtained in 2004 her diploma of 'Licentiate in the Biomedical Sciences / Master of Health Sciences'. During her study she ran an internship at the department of Health Risk Analysis and Toxicology (GRAT) at the Maastricht University, conducting research on DNA damage tolerance mechanisms and the mutagenicity of benzo[a]pyrene. For this research, she was awarded the prize for the best graduation research report in 2004 within the Molecular Life Sciences program.

Subsequently, from August 2004 until July 2008, she worked as a PhD student at GRAT at the Maastricht University. The research conducted during these years and presented in this thesis, occurred under supervision of Prof. Dr. F.J. van Schooten and Dr. R.W.L. Godschalk. In 2006, she went on an exchange visit of 3 months at the Department of Nutrition at the University of Oslo by means of a "NuGO exchange grant" to learn the 'in vitro base excision repair assay' from Prof. Dr. Andrew R. Collins. Next to conducting research, she attended several courses and obtained licenses for working with radioactive material (qualification level $5^{\mathrm{B}}$ according to the Dutch law), on handling laboratory animals (according to art.9 of the Dutch law on experimental animals), and for several modules as part of the Postgraduate Education in Toxicology in favour of the registration as a toxicologist. After obtaining her PhD title Sabine likes to conduct postdoctoral research abroad, for which she has recently submitted a couple of research proposals. 



\section{List of Publications and Achievements}

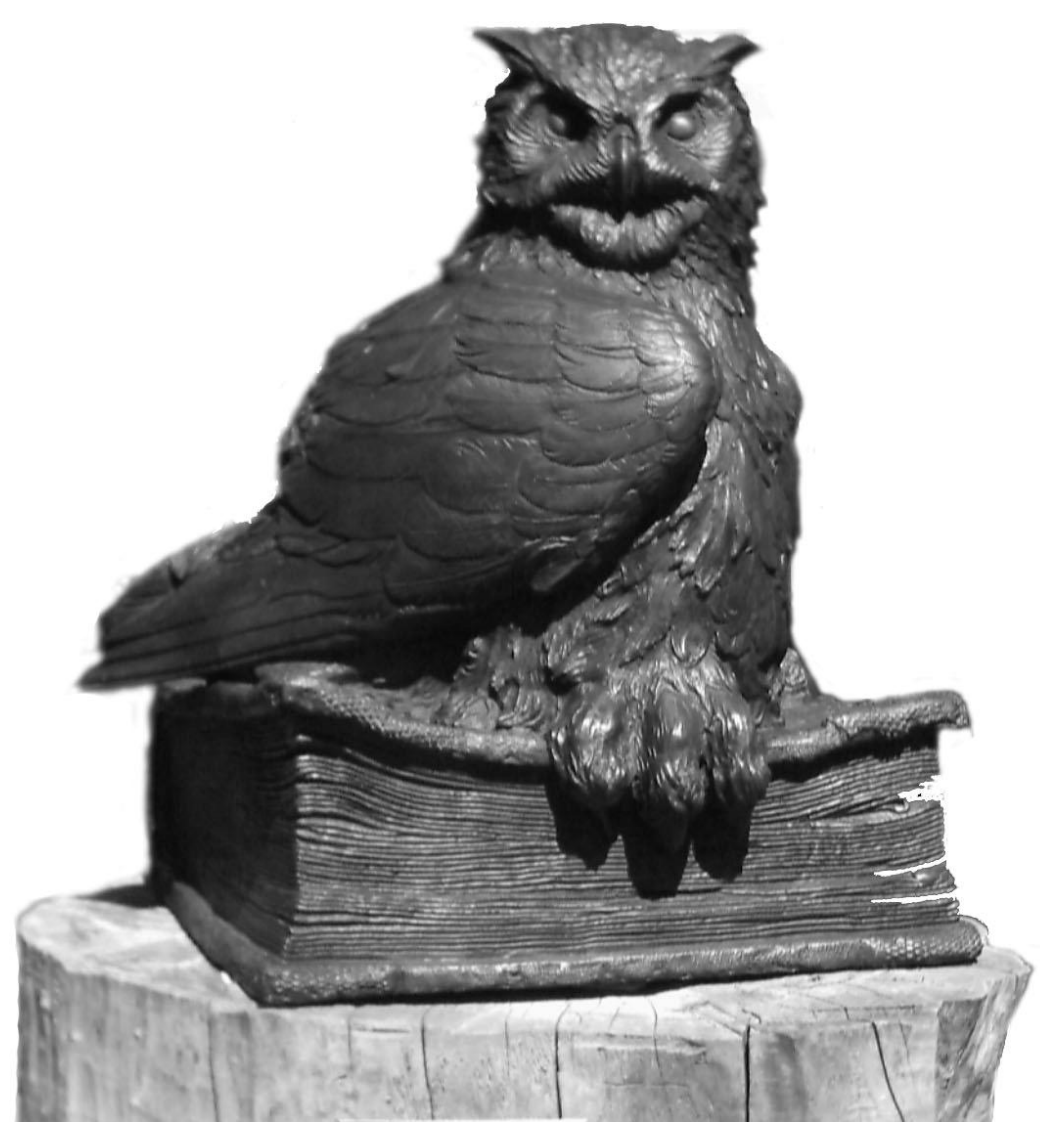





\section{Full papers}

Sabine A.S. Langie, Ad M.Knaapen, Karen J.J.Brauers, Damien van Berlo, Frederik J. van Schooten, Roger W.L.Godschalk. Development and validation of a modified comet assay to phenotypically assess nucleotide excision repair. Mutagenesis 21 (2006) 153-158

Sabine A.S. Langie, Ad M. Knaapen, Joyce M.J. Houben, Frederik C. van Kempen, Joep P.J. de Hoon, Ralph W.H. Gottschalk, Roger W.L. Godschalk, Frederik J. van Schooten. The role of glutathione in the regulation of nucleotide excision repair during oxidative stress. Toxicology Letters 168 (2007) 302-309

Sabine A.S. Langie, Ad M. Knaapen, Chantal H.M.A. Ramaekers, Jan Theys, Jan Brun, Roger W.L. Godschalk, Frederik J. van Schooten, Philippe Lambin, Douglas A. Gray, Bradly G. Wouters, Roland K. Chiu. Formation of lysine 63-linked polyubiquitin chains protects human lung cells against benzo[a]pyrene-diol-epoxideinduced mutagenicity. DNA Repair 6 (2007) 852-862

Sabine A.S. Langie, Pawel Kowalczyk, Barbara Tudek, Romuald Zabielski, Tomasz Dziaman, Ryszard Oliński, Frederik J. van Schooten, Roger W.L. Godschalk. In vivo dietary modulation of nucleotide excision repair in colon tissue of newborn piglets.

\section{Submitted}

Sabine A.S. Langie, Lonneke C. Wilms, Satu H. Hämäläinen, Jos C. Kleinjans, Roger W.L. Godschalk, Frederik J. van Schooten. Modulation of the nucleotide excision repair capacity in human lymphocytes by genetic and dietary factors.

\section{Submitted}

Joost O. Linschooten, Nicole Verhofstad, Sabine A.S. Langie, Frederik J. van Schooten, Roger W.L. Godschalk. Comparison of methodologies to assess mutation frequencies in somatic and germ cells. In preparation 


\section{Abstracts}

Sabine A.S. Langie, Lonneke C. Wilms, Satu H. Hämäläinen, Jos C. Kleinjans, Roger W.L. Godschalk, Frederik J. van Schooten. Modulation of the nucleotide excision repair capacity in human lymphocytes by genetic and dietary factors. Journal of Nutrigenetics and Nutrigenomics 1(6): 261-318, 2008. Poster presentation at the 2nd Congress of the International Society of Nutrigenetics/ Nutrigenomics (ISNN), October 2008, Geneva, Switzerland.

Sabine A.S. Langie, Lonneke C. Wilms, Satu Hämäläinen, Jos C. Kleinjans, Roger W.L. Godschalk, Frederik J. van Schooten. Modulation of DNA repair capacity in human lymphocytes by genetic and dietary factors. Mutagenesis 23(1) pp. i1-i13, 2008. Oral presentation at the PhD student meeting of the Netherlands Society of Toxicology and Annual Meeting of the NVT, June 2008, Wageningen, The Netherlands.

Sabine A.S. Langie, Roger W.L. Godschalk, Ad M. Knaapen, Frederik J. van Schooten. Phenotypic assessment of DNA repair. Poster presentation at the Biomedica 2008 conference, April 2008, Maastricht, The Netherlands.

Sabine A.S. Langie, Pawel Kowalczyk, Frederik J. van Schooten, Andrew R. Collins, Barbara Tudek, Olinski Ryszard, Roger W.L. Godschalk. Phenotypic assessment of DNA repair; Modulation by dietary factors in newborn pigs. Poster presentation at the VLAG-NZO Masterclass "Diet and Cancer", November 2007, Wageningen, The Netherlands.

Sabine A.S. Langie, Ad M. Knaapen, Frederik J. van Schooten, Roger W.L. Godschalk. Phenotypical assessment of DNA repair. Poster presentation at the 44th Congress of European Societies of Toxicology, October 2007, Amsterdam, The Netherlands.

Sabine A.S. Langie, Ad M. Knaapen, Frederik J. van Schooten, Roger W.L. Godschalk. Phenotypical assessment of DNA repair by a modified Comet Assay. Poster presentation at the First German-French Meeting on "DNA repair, damage signaling, and carcinogenesis", September 2007, Toulouse, France.

Sabine A.S. Langie, Pawel Kowalczyk, Frederik J. van Schooten, Barbara Tudek, Roger W.L. Godschalk. Modulation of DNA repair by dietary factors in newborn pigs. Mutagenesis 22 (6), pp. e1-e21, 2007. Oral presentation at the VII International Comet Assay Workshop, June 2007, Colerain, N-Ireland.

Sabine A.S. Langie, Frederik J. van Schooten, Roger W.L. Godschalk. Phenotypical assessment of DNA repair. Chemico-Biological Interactions 169 (2), pp. 132-143, 
2007. Oral presentation at the $\mathrm{PhD}$ student meeting of the Netherlands Society of Toxicology and Annual Meeting of the NVT, June 2007, Wageningen, The Netherlands.

Sabine A.S. Langie, Ad M. Knaapen, Joyce M.J. Houben, Frederik C. van Kempen, Joep P.J. de Hoon, Roger W.L. Godschalk, Frederik J. van Schooten. The role of glutathione in the regulation of nucleotide excision repair during oxidative stress. Poster presentation at the ECNIS Annual Meeting, February 2007, Maastricht, The Netherlands.

Sabine A.S. Langie, Ad M. Knaapen, Chantal H.M.A. Ramaekers, Jan Theys, Jan Brun, Roger W.L. Godschalk, Frederik J. van Schooten, Philippe Lambin, Douglas A. Gray, Bradly G. Wouters, Roland K. Chiu. Formation of lysine 63-linked poly-ubiquitin chains protects human lung cells against benzo[a]pyrene-diol-epoxide-induced mutagenicity. Poster presentation at the ECNIS Annual Meeting, February 2007, Maastricht, The Netherlands.

Sabine A.S. Langie, Ad M. Knaapen, Joyce M.J. Houben, Frederik C. van Kempen, Joep P.J. de Hoon, Roger W.L. Godschalk, Frederik J. van Schooten. Redoxdependent regulation of nucleotide excision repair. Toxicology Letters vol.164S S264, 2006. Poster presentation 43rd Congress of European Societies of Toxicology and 6th Congress of Toxicology in Developing Countries, September 2006, Cavtat/Dubrovnik, Croatia.

Sabine A.S. Langie, Ad M. Knaapen, Joyce M.J. Houben, Frederik C. van Kempen, Joep P.J. de Hoon, Roger W.L. Godschalk, Frederik J. van Schooten. Redoxdependent regulation of nucleotide excision repair. Chemico-Biological Interactions 161 (2), pp. 165-170, 2006. Poster presentation at the PhD student meeting of the Netherlands Society of Toxicology and Annual Meeting of the NVT, June 2006, Wageningen, The Netherlands.

Sabine A.S. Langie, Ad M. Knaapen, Karen J.J.Brauers, Frederik J. van Schooten, Roger W.L. Godschalk. A modified comet-assay to assess nucleotide excision repair. Oral presentation at VI International Comet Assay Workshop, September 2005, Warsaw, Poland.

Sabine A.S. Langie, Ad M. Knaapen, Karen J.J.Brauers, Frederik J. van Schooten, Roger W.L. Godschalk. A modified comet-assay to assess nucleotide excision repair. Poster presentation at 9th International Conference on Environmental Mutagens, September 2005, San Francisco, California USA.

Sabine A.S. Langie, Ad M. Knaapen, Roland K. Chiu, Roger W.L. Godschalk, Chantal H.M.A. Ramaekers, Bradly G. Wouters, Frederik J. van Schooten. The role of Lys63- 
linked polyubiquitin chains in repair and mutagenicity of benzo[a]pyrene-diol-epoxide (BPDE) DNA adducts. Poster presentation at 9th International Conference on Environmental Mutagens, September 2005, San Francisco, California USA.

Sabine A.S. Langie, Ad M. Knaapen, Karen J.J.Brauers, Frederik J. van Schooten, Roger W.L. Godschalk. A modified comet-assay to assess nucleotide excision repair. Poster presentation at 35th Annual Meeting of the European Environmental Mutagen Society, July 2005, Kos, Greece.

Sabine A.S. Langie, Ad M. Knaapen, Roland K. Chiu, Roger W.L. Godschalk, Chantal H.M.A. Ramaekers, Bradly G. Wouters, Frederik J. van Schooten. The role of Lys63linked polyubiquitin chains in repair and mutagenicity of benzo[a]pyrene-diol-epoxide (BPDE) DNA adducts. Poster presentation at 35th Annual Meeting of the European Environmental Mutagen Society, July 2005, Kos, Greece.

Sabine A.S. Langie, Ad M. Knaapen, Karen J.J.Brauers, Frederik J. van Schooten, Roger W.L. Godschalk. A modified comet-assay to assess nucleotide excision repair. Poster presentation at the PhD student meeting of the Netherlands Society of Toxicology and Annual meeting of the NVT, June 2005, Oss, The Netherlands.

Sabine A.S. Langie, Ad M. Knaapen, Roland K. Chiu, Roger W.L. Godschalk, Chantal H.M.A. Ramaekers, Bradly G. Wouters, Frederik J. van Schooten. The role of Lys63linked polyubiquitin chains in repair and mutagenicity of benzo[a]pyrene-diol-epoxide (BPDE) DNA adducts. Poster presentation at the $\mathrm{PhD}$ student meeting of the Netherlands Society of Toxicology and Annual meeting of the NVT, June 2005, Oss, The Netherlands.

Sabine A.S. Langie, Ad M. Knaapen, Roland K. Chiu, Roger W.L. Godschalk, Chantal H.M.A. Ramaekers, Bradly G. Wouters, Frederik J. van Schooten. The role of Lys63linked polyubiquitin chains in repair and mutagenicity of benzo[a]pyrene-diol-epoxide (BPDE) DNA adducts. Poster presentation at the 34th Annual Meeting of the European Environmental Mutagen Society, September 2004, Maastricht, The Netherlands.

Sabine A.S. Langie, Ad M. Knaapen, Roger W.L. Godschalk, Roland K. Chiu, Bradly G. Wouters, Frederik J. van Schooten. The role of polyubiquitin chains in repair of benzo[a]pyrene-induced DNA damage. Poster presentation at the 8th Maastricht Medical Students Research Conference, March 2004, Maastricht, The Netherlands. 


\section{Achievements}

Organized the PhD student meeting of the Netherlands Society of Toxicology and co-organized the Annual Meeting of the NVT, June 2008, Wageningen, The Netherlands.

Awarded financial support by the German Society for Research on DNA Repair (DGDR) and the Société Française de Toxicologie Génétique (SFTG), to support participation in the First German-French meeting on "DNA repair, cell signaling and carcinogenesis", September 2007, Toulouse, France.

Awarded ECETOC Young Scientist Award Prize for toxicological research into mechanisms and risk assessment, at the EUROTOX 2006/6 CTDC Congress, September 2006, Cavtat/Dubrovnik, Croatia. Poster title: "Redox-dependent regulation of nucleotide excision repair."

Awarded the NUGO exchange grant for an exchange project of three months to the University of Oslo in the summer 2006.

Awarded the Mutagenesis - Oxford University Press poster prize at the 35th Annual Meeting of the European Environmental Mutagen Society, July 2005, Kos island, Greece. Poster title: "The role of Lys63-linked polyubiquitin chains in repair and mutagenicity of benzo[a]pyrene-diol-epoxide DNA adducts."

Awarded financial support to attend to the 35th Annual Meeting of the European Environmental Mutagen Society, July 2005, Kos, Greece by the EU Network of Excellence ECNIS.

Awarded the poster prize at the PhD student meeting of the Netherlands Society of Toxicology and Annual Meeting of the NVT, June 2005, Oss, The Netherlands. Poster title: "A modified comet-assay to assess nucleotide excision repair."

Awarded the distinction Cum Laude for the Master's degree.

Awarded the prize for the best graduation research report within Molecular Life Sciences Translational University Limburg, academic year 2003-2004. Project title: "The role of polyubiquitin chains in repair and mutagenicity of benzo[a]pyrene induced DNA damage." 